Foraminifera and

Stratigraphy of the Upper

Part of the Pierre Shale and

Lower Part of the Fox Hills

Sandstone (Cretaceous)

North-Central South Dakota

GEOLOGICAL SURVEY PROFESSIONAL PAPER 611

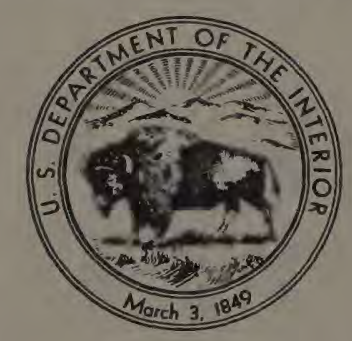




\section{Foraminifera and}

Stratigraphy of the Upper

Part of the Pierre Shale and

Lower Part of the Fox Hills

\section{Sandstone (Cretaceous)}

North-Central South Dakota By JAMES F. MELLO

GEOLOGICAL SURVEY PROFESIONAL PAPER 611 Description, illustration, and interpretation of the Late Cretaceous foraminiferal faunas of parts of the Pierre Shale and Fox Hills Sandstone, and discussion of the stratigraphy of these lithologic units

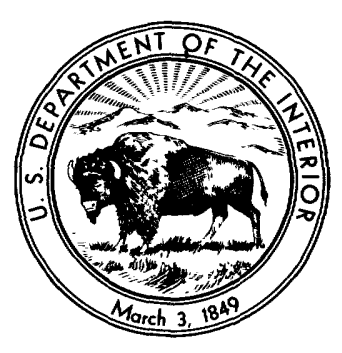




\section{UNITED STATES DEPARTMENT OF THE INTERIOR \\ WALTER J. HIGKEL, Secretary \\ GEOLOGIGAL SURVEY \\ William T. Pecora, Director}

Library of Congress catalog-card No. GS 68-365

For sale by the Superintendent of Documents, U.S. Government Printing Office Washington, D.C. 20402 - Price $\$ 2.25$ (paper cover) 


\section{CONTENTS}

Abstract

Introduction . . . .

Acknowledgments........

Field methods

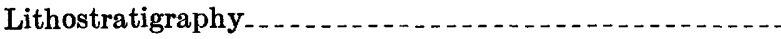

Earlier investigations

Lithology of the Pierre Shale . . .

Virgin Creek Member of the Pierre Shale . . ... .

Mobridge Member of the Pierre Shale.......

Elk Butte Member of the Pierre Shale........

Type sections of the members. . . . . . . . . .

General discussion of the lithologic subdivisions.

Distinctive features of the upper part of the

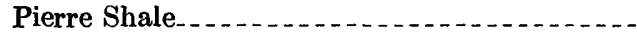

Methods of correlation

Composite stratigraphic sequences . . . . . . . . . . Stratigraphic sequence along the Moreau RiverStratigraphic sequence along the Grand River-Relationship of the sequences........

Biostratigraphy.

Regional correlation..............

Composition of the fauna

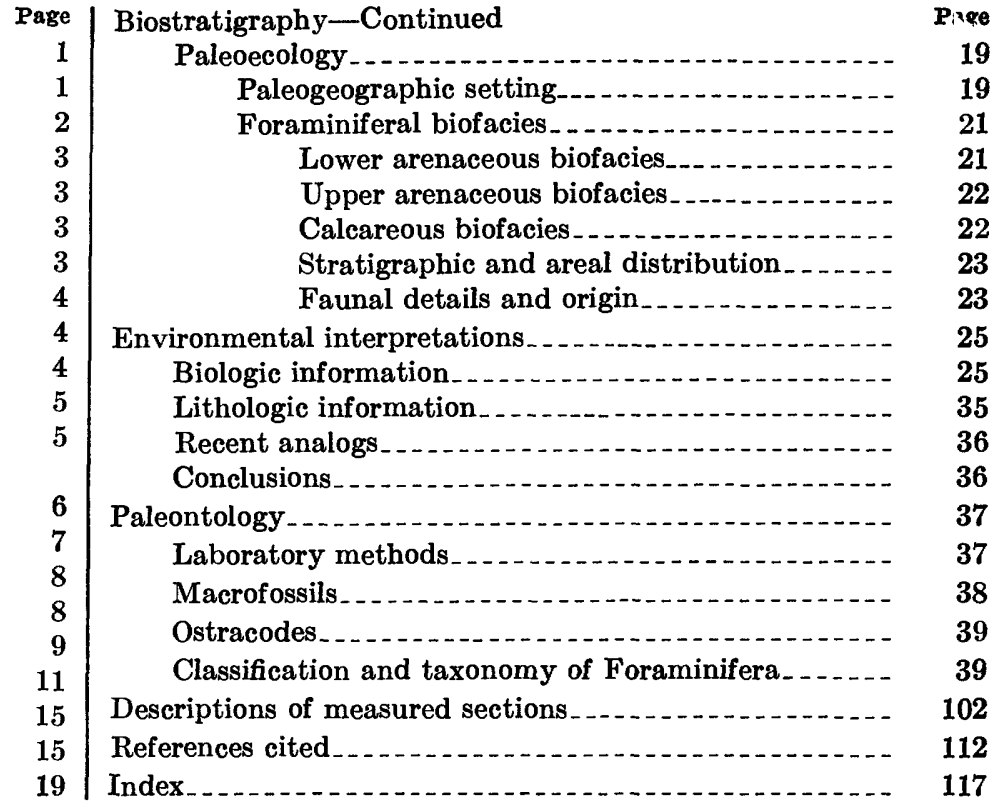

\section{ILLUSTRATIONS}

[Plates 1-11 follow index; plate 12 is in pocket]

Plate 1. Verneuilinoides, Pseudoclavulina?, Clavulinoides, Trochammina, Oolina, Fissurina, ?Loxostoma, and "Discorbis."

2. Nuttallinella?, Pullenia, Biglobigerinella, Rugoglobigerina, and Anomalinoides.

3. Incertae sedis, Anomalinoides, and Cibicides.

4. Bathysiphon, Reophax, Ammodiscus, Glomospira, Haplophragmoides, Spiroplectammina, and Gaudryina.

5. Pseudoclavulina?, Heterostomella, Silicosigmoilina, Quinqueloculina, Trochammina, and Robulus.

6. Marginulina, Astacolus, Dentalina, and Nodosaria.

7. Rectoglandulina, Citharina, Palmula, Frondicularia, Lagena, Oolina, Fissurina, Guttulina, and Globulina.

8. Pyrulina, Ramulina, Heterohelix, Bolivinopsis, Rectoguembelina, Bolivinoides, Tappanina, Eouvigerina, and Bulimina.

9. Bulimina, Neobulimina, Bolivina, Loxostoma, Pleurostomella, and Stilostomella.

10. "Gyroidina," Gyroidina, Osangularia, Quadrimorphina, "Discorbis," and Nuttallinella?.

11. Hoeglundina, Pullenia, Planulina, and Cibicides.

12. Graphic representations of measured sections in the upper part of the Pierre Shale and lower part of the Fox Hi's Sandstone (Cretaceous), north-central South Dakota. 
Figure 1. Index map of north-central South Dakota.

6. Charts:

2. Ranges of Foraminifera useful in local correlation from the Moreau River composite section.......

3. Ranges of Foraminifera useful in local correlation from the Grand River composite section

4. Correlation of stratigraphic sections along the Moreau River and environs........................

5. Correlation of stratigraphic sections along the Grand River and environs

6. Foraminiferal biofacies in composite stratigraphic sections along the Moreau and Grand Rivers....

7. Lithofacies and paleogeographic maps of the Western United States in Verendrye and Virgin Creek time,

Mobridge time, and Fox Hills time......

8. Graph showing the number of species in 192 samples from the upper part of the Pierre Shale and lower part

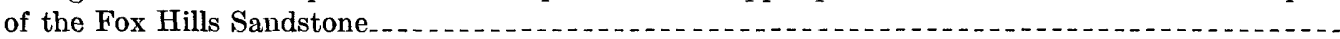

9-12. Graphs showing distribution of families in:

9. Fifty samples from the upper arenaceous biofacies_.

10. Sixty-six samples from the calcareous biofacies.

11. Fifty-three samples from the calcareous biofacies.

13-14. Charts:

12. Ten samples from the lower arenaceous biofacies

13. Composite stratigraphic ranges of Foraminifera in sections along and near the Moreau River.....

14. Composite stratigraphic ranges of Foraminifera in sections along and near the Grand River......

\section{TABLES}

TABLE 1. Gulf Coast stratigraphic distribution (after Cushman, 1946) of Foraminifera found in the upper part cf the Pierre Shale and lower part of the Fox Hills Sandstone

2. Analysis of the number of genera, number of species, planktonic-benthonic ratios, and percentage of arenaceous specimens in 67 samples from the upper part of the Pierre Shale representing the three recognized foraminiferal biofacies 


\title{
FORAMINIFERA AND STRATIGRAPHY OF THE UPPER PART OF THE PIERRE SHALE ANI LOWER PART OF THE FOX HILLS SANDSTONE (GRETAGEOUS), NORTH-GENTRAL SOUTH DAKOTA
}

\author{
By JAMES F. MeLLo
}

\begin{abstract}
Twenty-two stratigraphic sections along and near the Grand and Moreau Rivers in north-central South Dakota depict the stratigraphy of the Virgin Creek, Mobridge, and Elk Butte Members of the upper part of the Pierre Shale and the lower 74 feet of the Fox Hills Sandstone. The Virgin Creek Member, about 60 feet thick, is noncalcareous fissile shale in all but the upper 10 to 15 feet; in the lower 20 feet are numerous thin bentonite beds. The Mobridge Member, between about 200 and 225 feet thick, is typically calcareous shale with numerous concretion horizons and a few bentonite beds. The Elk Butte Member, 103 feet thick along the Moreau River and 192 feet thick along the Grand River, is noncalcareous shale with very few bentonite beds; it becomes very silty in the upper 15 to 30 feet. The lower part of the Fox Hills Sandstone is compacted but nonindurated sandy, clayey silt and silty, clayey sand, which in most places lacks bedding. Correlation of individual sections was made by means of bentonite beds and concretion horizons wherever possible. Two relatively thick bentonite beds in the Mobridge Member were used as datum planes. The contacts between the calcareous shale of the Mobridge Member and the noncalcareous shales of the Virgin Creek Member below and the Elk Butte Member above are gradational and are not uniform in stratigraphic position in sections correlated on the basis of bentonites.
\end{abstract}

One hundred and one species, subspecies, or varieties of Foraminifera from 57 genera and 20 families, including seven new species and 12 taxa which could not be identified to species, are described. Three stratigraphically separate foraminiferal biofacies are recognized :

1. The lower arenaceous biofacies in the lower 55 feet of the Virgin Creek Member. Arenaceous (agglutinated), porcellaneous, and siliceous Foraminifera are dominant in number of taxa.

2. The calcareous biofacies in the upper 5 feet of the Virgin Creek Member, throughout the Mobridge Member, and in the lower 55 feet or less of the Elk Butte Member. Calcareous perforate Foraminifera are dominant in both number of taxa and number of specimens.

3. The upper arenaceous biofacies in the upper part of the Elk Butte Member and the lower $\mathbf{7 4}$ feet of the Fox Hills Sandstone. Arenaceous (agglutinated) Foraminifera are dominant in both number of taxa and number of specimens.

The calcareous biofacies gradually changes upward into the upper arenaceous biofacies, but its boundary with the underlying lower arenaceous biofacies is more abrupt, the change taking place through a short stratigraphic interval.
Comparison of the 62 species and subspecies that occur in both the upper part of the Pierre Shale and in the Cretaceous deposits of the Gulf Coastal Plain indicates a probable ear'y Navarro age. Other comparisons also indicate an earliest Maestrichtian or latest Campanian age for the upper part of the Pierre Shale.

Paleoecological interpretations based on familial compositions of the faunas, foraminiferal number, planktonic-benthonic ratios, and lithologic data indicate that the upper part of the Pierre Shale and the lower part of the Fox Hills sandstone were deposited in waters less than about 200 feet deep. Deepest water conditions prevailed during deposition of the lower part of the calcareous biofacies. The water, however, became increasingly shallow during deposition of the calcareous and upper arenaceous biofacies. Shallowest conditions prevailed during depo sition of the upper part of the upper arenaceous biofacies. Faunal comparison at the family level indicates similarities betwe $n$ the upper and lower arenaceous biofacies which may reflect similar environmental conditions.

\section{INTRODUCTION}

Cretaceous rocks exposed in the Great Plains provin?e of the conterminous United States are admirably suited to broad areal stratigraphic study. The gently dipping strata crop out over wide areas, and light rainfall prevents thick plant cover. Many good, relatively fresh, measurable sections occur where streams have cut into the strata.

In north-central South Dakota, the essentially flatlying beds of the Fox Hills Sandstone and the Pierre Shale are exposed over hundreds of square miles and in many places are dissected by streams. Few authers have mentioned the commonly abundant Foraminifera from the upper part of the Pierre Shale, and none has placed these fossils in a detailed stratigraphic framework or attempted to determine what paleoecologic information could be inferred from them. There are no papers that deal with the faunas of the lower part of the Fox Hills.

The first objective of the present study was to measure and examine a number of exposures to work out the stratigraphic succession in the upper part of the Pierre 
Shale. Seventy-four sections were measured during this study; locations of the 23 most significant sections are shown in figure 1. The second objective was the systematic sampling of many of the measured sections for Foraminifera. The purpose here was to obtain microfaunas from known stratigraphic positions for identification and description and for study of ranges, abundances, associations, and paleoecologic implications.

Four of the 23 sections extend upward into the lower part of the Fox Hills Sandstone. Foraminifera from these sections were noted, but no detailed stratigraphic study of the Fox Hills was made.

The present investigation covers much of Corson and Dewey Counties and a very small part of Ziebach County. Within this area, suitable outcrops are confined to the valleys of the Moreau and Grand Rivers, eastflowing major tributaries of the Missouri River, to the valleys of their main tributaries, and to some recently opened railroad cuts in the vicinity of Wakpala in Corson County.

\section{ACKNOWLEDGMENTS}

The assistance of the following persons and institutions is gratefully acknowledged:

Prof. Karl M. Waagé of Yale University and the U.S. Geological Survey acquainted me with the Upper Cretaceous deposits of South Dakota, suggested the problem, and provided a great deal of help and encouragement during the course of research. Prof. A. Lee McAlester of Yale University and Dr. Johr Sanders of Hudson Laboratories gave valuable advice and assistance. I am especially grateful for the help of my colleague, Miss Ruth Todd, whose knowledge of J'oraminifera was called upon frequently. I am also grateful to Dr. William A. Cobban, Dr. Norman Sohl, and Dr. J. Thomas Dutro, all of the U.S. Geological Survey, and to Mr. Ernesto Sarpi of Columbia University for reading the manuscript and providing numero's useful criticisms.

Photographs of the Foraminifera were made by $\mathbf{M r}$. David Massie of the U.S. Geological Survey; the draw-

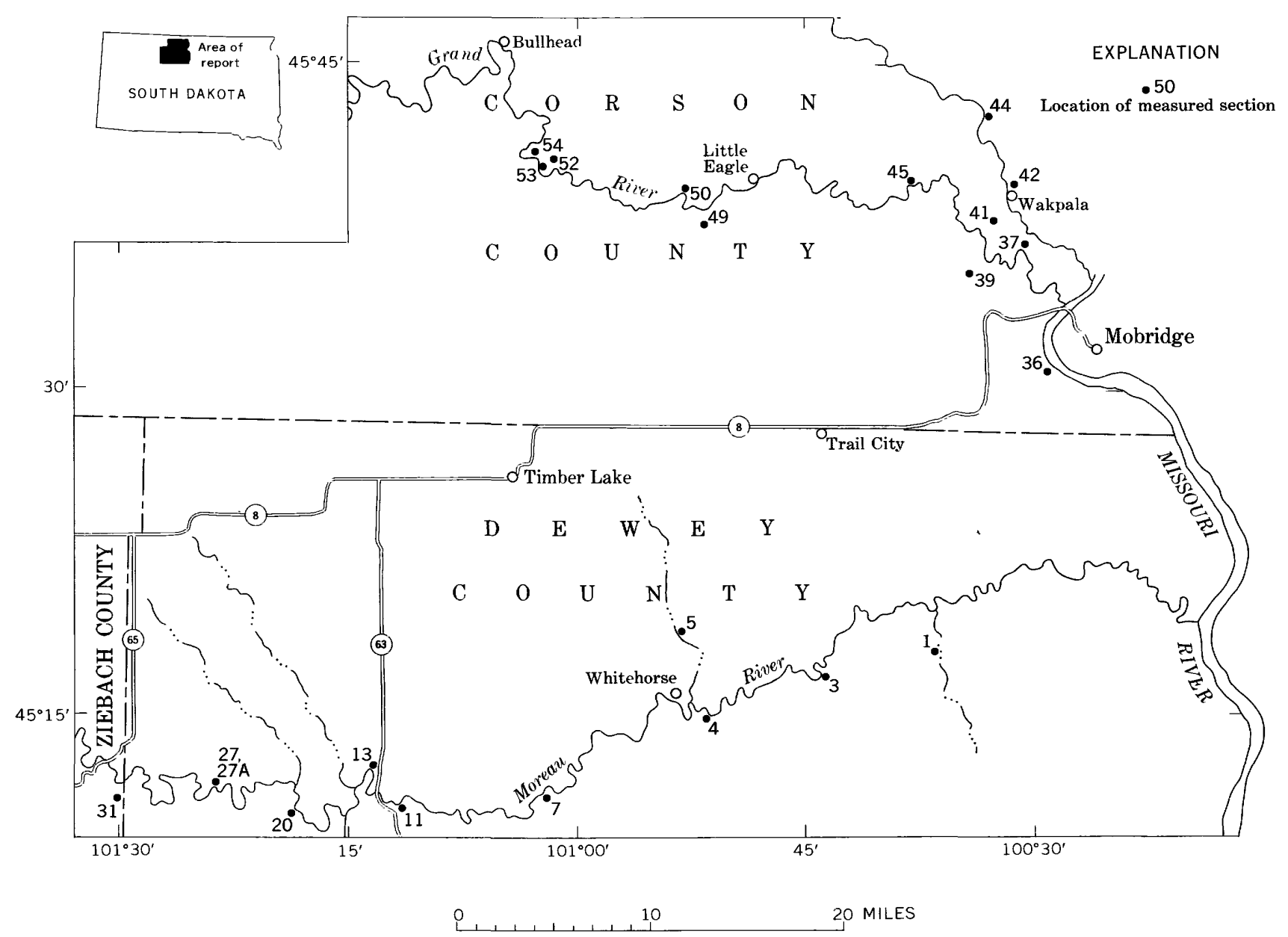

Figure 1.-Index map of north-central South Dakota showing approximate locations of measured sections. Location numbers shown here match section numbers shown on plate 12 and in figures 4 and 5 . 
ings are the work of Mrs. Elinor Stromberg of the U.S. Geological Survey.

Fieldwork and research were supported in part by funds from the Yale University Schuchert Fund, by the Society of the Sigma Xi through two grants from the Sigma Xi RESA Research Fund, and by the U.S. Geological Survey.

\section{FIELD METHODS}

Good exposures were found by reference to topographic maps and aerial photographs and by field reconnaissance. The main factors determining choice of slopes to be measured were vertical thickness of the exposure, degree of freshness of the surface, and position with respect to other measured sections. It was usually possible to find sections that had sufficient overlap with nearby sections to make correlation possible. Because altitude increases gradually to the west, successions of stratigraphically higher sections were found by following the rivers westward; however, both largescale and small-scale slumping made altitude a useless criterion for correlation. The slopes were first trenched to a fresh surface from top to bottom along at least one vertical line. Measurement was made by hand level and steel tape. Color, hardness, calcareous content, and silt-sand content of the shale were noted, as were concretions, bentonites, and other distinctive horizons. Color-chart comparisons were not made because the color of the shale varied widely with moisture content.

Lithologic samples, where desired, were taken at each hand-level interval (5 ft 9 in.) except where special circumstances required closer or more widely spaced samples. Every effort was made to secure fresh, uncontaminated shale for these samples.

\section{LITHOSTRATIGRAPHY}

In the following discussion no attempt is made to give a complete history or lithologic description of the Pierre Shale. The history of exploration and interpretation of the Cretaceous rocks of the western interior has been summarized by Cobban and Reeside (1952, p. 1014$1015)$ and is described in detail in articles to which they refer. Therefore, only the major contributions pertaining to the stratigraphy and lithology of the upper part of the Pierre Shale in north-central South Dakota are discussed here. A brief historical summary is given first; a lithologic description of the members of the upper part of the Pierre Shale as originally defined and as modified by other authors follows; and, finally, these members and their modifications are discussed in the light of my studies.

\section{EARLIER INVESTIGATIONS}

The extensive Cretaceous deposits of the western interior of the United States were first studied by F. B. Meek and F. V. Hayden during the middle of the 19th century. The stratigraphic succession was subdivided into five formations (Meek and Hayden, 1856, p. 63). They later (1861, p.419) gave the names Dakota Group, Fort Benton Group, Niobrara Division, Fort Pierre Group, and Fox Hills beds to formations 1 through 5, respectively. The type area of the Fort Pierre Group lies about 60 miles south of the area investigated for this report, near the city of Pierre.

After Meek and Hayden's survey, no detailed stratigraphic work was done on the Pierre Shale in this area until Searight (1937) subdivided the Pierre into five members in central and southeastern South Dakota. These are, in descending order, the Elk Butte, Mobridge, Virgin Creek, Sully, and Gregory Members. Searight (1937), and others have since renamed and redefined several of these members. The last of these revisers was Crandell (1950); his subdivisions (1958, fig. 4), in descending order, are: Elk Butte Member, Mobridge Member, Virgin Creek Member, Verendrye Member, DeGrey Member, Crow Creek Member, Gregory Member, and Sharon Springs Member.

All revisers of Searight's original subdivisions of the Pierre have recognized the Elk Butte, Mobridge, and Virgin Creek Members, which are grouped under the general designation "upper part of the Pierre Shale" in this paper. However, there have been differences of opinion and interpretation regarding the boundaries of the Mobridge Member. These differences are discussed further on.

\section{LITHOLOGY OF THE PIERRE SHALE}

The term "shale" applied to this unit is somewhat misleading because "The Pierre formation as a whole consists of stratified gray, dark gray to black clays and shale, concretions, marls and chalks, interbedded with many layers of bentonite" (Petsch, 1946, p. 26). The Pierre Shale in the area investigated for this report is typicaly a dark-gray claystone or clay shale (terminology after Dunbar and Rodgers, 1957, p. 166). The rock contains only minor amounts of silt and sand except in the upper part directly below the Fox Hills Sandstone. Bedding is very obscure in fresh exposures but is emphasized by weathering. Bedding fissility is evident in some beds, which typically break down into small chips before decomposing into mud. Bentonite layers, concretions, and other distinctive lithologic features are present at many levels. The rock is not well indurated and weathers rapidly to gentle slopes which are havily covered with soil, rock fragments of various sizes, or tough 
gumbo. Steeper slopes and fresher exposures are maintained near drainage, and on these exposures the rock is commonly a light to medium gray or is lightly stained to various shades of brown, maroon, and red.

The upper part of the Pierre Shale in the area investigated was subdivided into the Elk Butte, Mobridge, and Virgin Creek Members by Searight, and the type sections for these members are within this area. In the following paragraphs the distinctive lithologic features of these three members are summarized by using either direct quotes or paraphrasings of Searight's (1937, p. $35-38,44-46,50-56)$ original descriptions of the members.

\section{VIRGIN CREEK MEMBER OF THE PIERRE SHAIE}

The Virgin Creek Member is defined to include “*** all beds between the Sully Member and the highly calcareous, chalky beds of the Mobridge Member. It thus includes the bentonite bearing shales which lie above the Verendrye zone [Verendrye Member of Crandell, 1952], with its characteristic iron carbonate concretions, and all characteristically noncalcareous beds to the base of the Mobridge" (p. 35).

The Virgin Creek Member was divided by Searight into two zones on the basis of lithology. "The lower of these [the lower Virgin Creek zone] is composed of relatively resistant, light to medium gray shale which contains a number of thin but conspicuous bentonite beds" (p. 36). The shale of the lower Virgin Creek zone is relatively resistant to erosion and usually is stained various shades of rusty brown, maroon, and purple on clean exposures. It typically breaks down into chips and flakes, which are brittle and harsh to the touch. "Thin bentonite beds [ $[1 / 2$ to $11 / 2$ in. thick] are a characteristics feature of the lower Virgin Creek. Indeed, it is on the basis of numerous thin white bentonite streaks across the outcrops that these beds are most readily distinguished" (p. 36). Concretions, though present in the Virgin Creek Member, are not abundant. However, a layer of concretions at the type section serves to mark the base of the member.

"The upper part of the Virgin Creek [the upper Virgin Creek Zone], especially the lower beds, breaks down to leaden gray gumbo, in many places tinged with rusty brown. The upper Virgin Creek in many places contains characteristic, small fossiliferous concretions in the lower part and a bed containing large limestone concretions, in some cases very fossiliferous, in the upper part" (p. 36). "Included in the upper Virgin Creek are those beds of shale which lie above the bentonitic lower Virgin Creek and below the highly calcareous shale and chalk of the Mobridge Member" (p. 37). The upper Virgin Creek shale erodes readily to gumbo, and good exposures are few. Where fresh rock is observable, it “**** consists of gray shale which weathers rapidly to light gray, leaden gray, and brownish gray gumbo which is arranged in horizontal bands of varying widths" (p. 37).

The small fossiliferous concretions referred to above are sporadically distributed in the lower part of the upper Virgin Creek zone and are buff gray and brown when fresh but weather to light tan or off rhite. They are typically formed about pelecypods, baculites, crabs, and other fossils and are usually perforated with small holes.

\section{MOBRIDGE MEMBER OF THE PIERRE SHALE}

Searight (1937, p. 44) described the Mobridge Member as $6 * * *$ a succession of highly calcareous shale, marl, and chalk beds which lies above the gumboforming shales of the Virgin Creek Member and below the noncalcareous shale beds of the Elk Butte Member. The member forms a wide buff band on the outcrop between the dark color of the underlying and overlying beds." The member "*** consists of medium gray and medium bluish gray to dark gray shale and chalk" and is $6 * * *$ everywhere highly calcareous and more or less chalky $* * * "$ (p. 45). Limestone lences and concretions of several kinds are present at many horizons in the Mobridge Member. Fossils do not commonly occur in the concretions, but concretionary material is always present within the living chambers of specimens of Baculites. Also present are lenses of calcareous material that have cone-in-cone structure and th at range in thickness from a fraction of an inch to sereral inches. Bentonite beds are not as numerous in this member as they are in the lower part of the Virgin Creek Member, but several of the bentonites are fairly thick (6 to 16 in.) and were used as a means of correlation. Searight did not note any thick bentonites in the Mobridge Member.

\section{FLK BUTTE MEMBER OF THE PIERRI SHALE}

The Elk Butte Member is defined as including “*** all beds in South Dakota betweer the top of the Mobridge Member and the base of tha Fox Hills Formation. It thus includes as its basal bec's those noncalcareous shales which immediately overlie the calcareous $* * *$ shales of the Mobridge Member. The upper limit, which is at the Pierre-Fox Fills contact, cannot be placed with extreme exactness, even at the type locality, where the basal Fox Hills is a massive sandstone, because the contact is one of gradation" (Searight, 1937, p. 50). Lithologically, the member $" * * *$ consists of very fine-texturyd, medium gray shale which is apparently very uniform through- 
out" (p. 51). Commonly on steeper slopes the shale initially breaks down into thin, flat chips which weather to gumbo. The rock becomes brownish gray as the sand and silt content increases toward the top of the member. Layers of concretions are also sporadic in this member, and near its top there are a few very large (as much as $3 \mathrm{ft}$ in idiameter) limestone concretions. Bentonite beds in the Elk Butte Member are sparse and usually less than an inch thick.

\section{TYPE SECTIONS OF THE MEMBERS}

The lower part of the Virgin Creek Member was still well exposed in 1962 at the type section, but the upper part of this member was not. The perforated concretions described by Searight from the lower part of the upper zone of the Virgin Creek were weathering out of the gumbo-covered slopes at and near the type locality. The concretion layers described by Searight at and near the base of the Virgin Creek Member were still visible.

The type section of the Mobridge Member is a series of roadcuts which apparently were fresh when Searight measured the section but which are now heavily soil covered and poorly exposed. The construction of the Oahe Dam, near Pierre, has created a lake which had covered part, if not all, of the Virgin Creek Member exposed at the type locality of the Mobridge Member in 1962. In addition, there seemed to be many slump blocks, some quite large, in the vicinity of the type section. It is now impossible to determine whether Searight's description of the type section included any of these slump blocks.

The type section of the Elk Butte Member, which consists of small exposures along 4 miles of old U.S. Route 12, extends from the top of Rattlesnake Butte, erroneously called Elk Butte by Searight, to a short distance west of Wakpala. Here again, exposures, which must have been fresh when Searight visited the area, were heavily covered in 1960 . Even the part of the section that extends up Rattlesnake Butte was too heavily weathered and talus covered to permit observation of the rock.

\section{GENERAL DISCUSSION OF THE IITHOLOGIC SUBDIVISIONS}

Modifications of Searight's (1937) stratigraphic interpretations of the upper part of the Pierre Shale have been of two general kinds. One, of lesser significance, has been the clarification of the local lithology. Those who have studied the sequence in more detail than Searight, and with different purposes, have naturally uncovered new facts or have made new interpretations of old facts. For the most part these local details supplement rather than modify Searight's description of the general lithology and stratigraphy. Specific information of this sort gathered in the present investigation will be introduced in order to place it on record.

Second, and more important, are modifications of. boundary criteria and means of correlation of the Mobridge Member. Although stratigraphers have consistently recognized the Virgin Creek, Mobridge, and EllButte Members (see Crandell, 1958, fig. 4), there are : number of difficulties in determining the boundaries of the Mobridge Member. In the southern part of Soutl Dakota, "*** the lower and upper contacts of the chalky Morbridge zone are sharp and easily found * * *," according to Gries (1942, p. 27). But Crandell (1958, p. 16-17), working in the vicinity of Pierre, S. Dak., had some difficulty in choosing the contacts of the Mobridge Member. He concluded that "The base of the Mobridge Member thus is here [Pierre area] defined as the contact between calcareous shale that weathers to a grayish-orange ('buff') color and somewhat calcareou" shale that weathers gray." Crandell also used color change to define the contact between the Mobridge and Elk Butte Members. He stated (1958, p. 18) that "Th" contact used to delimit the two members is the line of division between the grayish-orange-weathering shale of the Mobridge and the gray gumbo-forming beds of the Elk Butte Member." Rothrock (1947), who studied the Pierre Shale in and around the type area of the Mobridge Member, also was unable to determine consistently the contacts of the Mobridge Member on the basis of the reaction of the shale to acid. Furthermore, he apparently recognized no color change that he could use to define the contacts because his new criteria for member definition did not include color.

Like Rothrock, I have found that first and last occur:rences of calcareous shale vary in stratigraphic position from section to section and that no color change or other lithologically or faunally distinct horizons consistently parallel these changes.

The contacts of the Mobridge Member with the Virgin Creek and Elk Butte Members in north-central South Dakota are entirely gradational. The markedly lighter color that sets off the Mobridge Member from the E]k Butte and Virgin Creek Members to the south is not noticeable in the area investigated. In order to delimit boundaries of the Mobridge Member more precisely, some authors have chosen bentonite beds and concretic $n$ horizons as markers. Because of the local extent of such markers, however, they are of no use in defining widely recognizable boundaries. No attempt is made here to establish precise limits of the Mobridge Member, ard the boundaries of the member are considered to be intervals of transition between calcareous and noncalcareous rocks. For purposes of graphic representation, however, 
FORAMINIFERA, STRATIGRAPHY, PIERRE SHALE, FOX HILLS SANDSTONE, S. DAK.

the boundaries of the Mobridge Member are shown as lines that mark the first and last occurrences of significant thicknesses of calcareous shale.

In summary, the upper part of the Pierre Shale, although quite homogeneous in its general character, can be subdivided primarily on the basis of detectable calcium carbonate. The calcareous middle part of the rock succession is the Mobridge Member, the Virgin Creek Member being below and the Elk Butte Member above. The contacts between these members are gradational and probably not precisely synchronous over the area investigated. Although recognition of the Mobridge Member solely based on calcium carbonate content is less precise than Searight (1937) originally intended, the basic distinguishing calcareous character of the Mobridge is retained. In all probability the increased calcium carbonate content of the Mobridge Member reflects an environmental change which resulted either in an absolute increase in production of calcium carbonate or an increase relative to the rate of sedimentation. If so, any contact determined solely on calcium carbonate content will be gradational, in the sense that the stratigraphic level at which the calcium carbonate increase first becomes noticeable will vary between outcrops and even within single outcrops. However, local fluctuations of calcium carbonate content may reflect local and atypical diagenetic or postdiagenetic conditions.

Because only two measured sequences cross the Virgin Creek-Verendrye boundary as defined by Searight, little can be said concerning the nature of this contact. Where it was observed, there seemed to be no lithologic change at all. The boundary between these two members has been termed gradational by Gries $(1942$, p. 23).

The boundary between the Elk Butte Member and the Fox Hills Sandstone was clearly described by Searight (1937, p. 50) as gradational, and my own observations confirm this. Several attempts have been made to define this boundary more precisely by means of "jarosite" and other distinctive layers in detailed local stratigraphic studies (Waagé, 1961, p. 232, 233; Rothrock, 1947 , p. 5). In this investigation, the contact has been selected at or near a subjectively determined change from silty shale to clayey silt. Again, for purposes of graphic representation, this boundary is shown as a sharp line rather than as a gradational interval.

One of the original aims of this investigation was to delimit the members of the upper part of the Pierre Shale more precisely, and it is unfortunate that no sound criteria for accomplishing this purpose could be found, especially as the type sections of the Elk Butte, Mobridge, and Virgin Creek Members lie within the area investigated. Rothrock (1947) attempted a more precise definition of lithologic units in this area by trying to use a framework of key beds, but he failed to present either measured sections or adequate discussion of his new subdivision boundaries. The criteria or which he based his subdivisions could not be recognized in the course of this study, and, consequently, I could not apply his subdivisions to the stratigraphic succession.

Hereafter, the terms Virgin Creek, Mobridge, and Elk Butte are used only to denote the lower noncalcareous, middle calcareous and upper noncalcareous lithologies, respectively, with no precisely defined boundaries implied.

\section{DISTINCTIVE FEATURES OF THE UPPER PART OF THE PIERRE SHALE}

Generally speaking, the upper part of the Pierre Shale is lithologically monotonous, but it does contain many distinctive features which have been referred to by previous workers. Some of these features I have found useful in correlation. Color of the shale, steepness of outcrop slope, and size and nature of tha particles produced by weathering have all been used by others to characterize various parts of this shale sequance. However, these features are largely dependent upon the degree of weathering to which the outcrop has been subjected. Although such features may be charecteristic of particular types of shale after a certain amount or kind of weathering, they are of limited use in st:atigraphic work.

Concretions in the shale exhibit a wide range in size, color, reaction to acid, and composition. Smell, variously shaped, white-weathering, very calcareous, not very compact, and commonly perforated concretions with or without a harder limy core occur in noncalcereous shale at several levels. Crabs and other fossils are: sometimes found in this type of concretion in the Virgin Creek Member. Larger, ovoid to spherical blue-gray limestone concretions which also weather white or buff have been found at many levels. They are not confined to any particular type of shale and locally contain fossils. They may be septariate, and in many the cracks are filled with yellow calcite crystals. Most concretions observed during this study weather rusty red and are discoidal in shape. The interiors of these concretions range from brownish gray and moderately calcareous to brick red and noncalcareous. Reduction in calcareous content generally parallels increase in redness in these concretions, but the existence of calcareous red-cored concretions and noncalcareous gray-cored concretions indicates that this parallelism is not complete. In several places concretions that are predominantly gray with only a thin red rind have been traced from fresh exposures onto more weathered slopes where the concretions in the same layer are red all the way through. At one place this type 
of concretion weathered a deep purple and had a polished surface. In addition to these more common kinds of concretions, limy internal molds of the living chambers of baculites, heavy gypsum incrustations around pelecypods and ammonites, and small barite concretions have been found.

Bentonite beds are common in the lower two-thirds of the upper part of the Pierre Shale and are very common in the lower one-third. They are typically waxy yellow or green and have a sharp basal contact and a gradational upper contact. Many bentonite beds are graded, and in these the silty lower part contains abundant dark flakes of biotite and clear angular quartz grains. Several distinctive materials are frequently associated with the bentonites and sometimes replace them. These include thin stringers of vertically fibrous calcite, bands with cone-in-cone structure, and limestone concretions 3 to 12 inches thick. The most common associate is a powdery yellow mineral, questionably identified as melanterite. The same or a similar mineral occurs in the Fox Hills sandstone and has been called jarosite, bentonite, and melanterite (Waagé, 1961, p. 233). Melanterite(?) occurs directly above and (or) below many bentonites, and the stratigraphic intervals of individual bentonite beds are sometimes occupied solely by beds of shale containing considerable amounts of melanterite(?). Whether this mineral is an alteration product of bentonite or is related to it in some other way is not known. It also occurs independently of discrete bentonite beds as scattered pods and blebs in the shale. The vertically fibrous calcite, cone-in-cone structure and limestone concretions also occur independently of discrete bentonite beds as well as being associated with them and occupying the stratigraphic positions where the bentonites themselves are absent.

During the course of fieldwork an effort was made to determine the silt-sand content of the shale at regular intervals for each measured section. A small piece of fresh shale was crushed between the teeth and the degree of grittiness subjectively assigned to one of five categories; very, quite, moderately, slightly, or nonsilty. The variations in silt-sand content so determined do not appear to bear any consistent relationship to other lithologic features and are apparently of only limited lateral extent. Generally speaking, the silt-sand content is low throughout most of the upper part of the Pierre Shale but gradually increases as the Fox Hills sandstone is approached. This increase eventually results in the transition of the shale into the clayey sandy silt of the basal part of the Fox Hills sandstone.

Calcareous content was determined on the outcrop by putting a few drops of 10-percent hydrochloric acid on a fresh chunk of shale. The degree of reaction was sub- jectively rated, and the shale was designated very, quite, moderately, slightly, or noncalcareous. These evaluations have been illustrated for all sections discussed in this report by the vertical lines at the right sides of th stratigraphic columns (pl. 12). Calcareous shale generally contains the most abundant and diversified assem blages of calcareous Foraminifera, and the calcareous reaction may be due to the dissolution of the contained tests of these fossils or of their recrystallized remains. The scarcity of calcareous-shelled macrofossils and macrofossil molds suggests that they did not contribute much calcium carbonate to the shale. Any contributions by organisms smaller than Foraminifera, such as coccolithophores, are not known.

The lower part of the Virgin Creek Member has been described as siliceous by Rothrock $(1947$, p. 12), who stated "A short distance south of [the mouth of] the Moreau [River] this zone [lower part of the Virgin Creek] becomes siliceous and north of the Moreau as far as it could be traced it was entirely siliceous." Radiolaria, which are often found in siliceous shales, were found in samples from two sections of the lower part of the Virgin Creek Member (fig. 1, loc. 1, 3). The few calcareous Foraminifera in this interval are usuall preserved as internal molds in silica or are filled with silica. In addition to these occurrences, Radiolaria have been found through considerable stratigraphic thiclnesses of shale at localities 44,49 , and 52 and in the lower part of the Fox Hills Sandstone at locality 50. Through each of these intervals the few specimens cf calcerous Foraminifera that are present are silicified. These noncalcareous Radiolaria-bearing shale intervals resemble the lower part of the Virgin Creek Member but differ because they are less fissile and more clayey and lack heavy staining. Rubey (1929) discussed in detail the origin of the siliceous Mowry Shale and concluded that the silica was derived from the alteration of $\mathrm{vo}^{1}$ canic ash. He stated $(1929$, p. 153$)$ that "As a probable method of this derivation, it is suggested that the original ash was unusually siliceous, that it was decomposed by long exposure to sea water, and that silica dissolved from it was precipitated by decaying organic matter." The exhaustive information on which Rubey based his conclusions for the Mowry Shale is not available for the upper part of the Pierre Shale. However, for the bentonitic shale in the lower part of the Virgin Creek Member at least, similar conditions may have produced the abundance of silica reflected in the preservation and composition of the microfauna.

\section{METHODS OF CORRELATION}

The sections measured along the Grand and Moreau River valleys have been fitted together (figs. 4,5 ) to 
establish the stratigraphic sequences in these major areas of outcrop. Correlation of local sections is complicated by a considerable amount of slumping that involves both large and small bodies of shale. Most sections contain one or more key beds which make correlation with other nearby sections possible. The most useful key beds are bentonites, but concretion horizons, zones of increased or decreased calcareous content, and other distinctive lithologic features were used as a check on the correlations based on bentonites and were themselves used for correlations where bentonites were absent. Dependence on bentonites for correlation gradually increased during the course of fieldwork as it became apparent that they persisted farther laterally than other lithologically distinctive beds. In addition, bentonites are ideally suited for correlation because individual beds precisely define time planes. Generally speaking, the thickest beds were recognizable over the widest areas. Beds less than an inch thick locally disappeared between sections only a few miles apart, but their levels were commonly marked by vertically fibrous calcite, cone-in-cone structures, or beds of shale containing melanterite (?).

Macrofossils are too rare in the upper part of the Pierre Shale to be useful for local correlation, but their regional distribution is better known, and they are useful for broader scale correlations. The opposite is true for Foraminifera. In order to use the Foraminifera most successfully, it was necessary to establish a reference stratigraphic sequence by physical means. The stratigraphic positions of other sections were then inferred by comparing their microfaunas with the microfaunas of the reference sequence. The assumptions were that changes which took place in the microfauna at one locality also took place over a wider area and that these changes were synchronous, or nearly so, over this area. Generally speaking, the more species of Foraminifera in a sample, the more closely the sample could be related to samples from other sections. Species that were abundant within limited stratigraphic ranges are the most useful for relating sections, and a list of such species and their ranges in the area is given in figures 2 and 3.

\section{COMPOSITE STRATIGRAPHIC SEQUENCES}

Figures 4 and 5 illustrate the composite stratigraphic sequences along the Moreau and Grand Rivers, respectively. It is not considered feasible or necessary to describe all 74 sections measured during this investigation. Figures 4 and 5 show the 23 sections from which samples were examined for microfossils. This group of sections contains the more stratigraphically significant ones measured. In the following paragraphs the nature of these composite sequences is explained, and pertinent details are noted.

\section{STRATIGRAPHIC SEQUENCE ALONG THE MOREAU RIVER}

Of the sections measured along the Moreau River (see figs. 1,4) only sections 1 and 3 extend to the base of the Virgin Creek Member. The base of section 1, which is within half a mile of the type locality of the member, is at the more persistent and lower of two clorely spaced concretion horizons, presumably the concretion layer which Searight described as forming the kase of the member. Section 1 was correlated with section 3 on the basis of the numerous thin bentonites and fissile maroonto purple-stained shale in the lower parts of both sections. Seven thin bentonites occur in the lower 20 feet of section 1 , and five occur in the lower 20 feet of section 3. In both sections the distinctive staining and fissility gradually disappear above the bentonite interval, and in section 3 , which extends much higher, the shale grades imperceptibly into the overlying nonfissile calcareous shale. The first calcareous shale occurs about 58 feet above the base of section 3. The upper limit of the silicified and siliceous microfauna and the initial increase in the number of species and specimens of calcareous Foraminifera occur 5 to 10 feet below this level. The calcareous shale that is more or less persistent throughout the remaining 75 feet of section 3 contains 12 bentonite beds.

Correlation of section 3 with sections 4 and 7 was made based on two of the uppermost and trickest bentonites. In section 7 the upper of these bentonites is overlain by 65 feet of calcareous shale contrining only a few thin bentonites. This interval is crpped by a prominent and persistent bentonite, referred to hereafter as the "lower key bentonite," which attains a thickness of 10 inches in section 7 but is less than 4 inches thick in section 20 farther to the west. Ovoid, tan- to buff-weathering calcareous concretions and more discoidal rusty-weathering calcareous concretions are common locally above this bentonite, though none were found in section 7 .

The shale is mostly calcareous for 54 feet above the lower key bentonite, but noncalcareous rust-stained beds of shale, some of which contain pods and blehs of melanterite (?), are present at various levels. In the sections to the west, this interval is capped by a second thick bentonite, referred to hereafter as the "upper key bentonite," which is 16 inches thick in section 27 but decreases in thickness to the east. This bentonite layer is 
FORAMINIFERA, STRATIGRAPHY, PIERRE SHALE, FOX HILLS SANDSTONE, S. DAK.

absent in section 7, where its level is occupied by a layer of shale 3 to 4 feet thick which contains considerable amounts of melanterite(?).

Calcareous shale persists for as little as 12 feet to as much as 49 feet above the upper key bentonite. The sections used in compiling figure 4 show a general thickening of this interval to the west, but this situation is fortuitous. Several other sections measured in the vicinity of localities 11 and 20 , but not shown in figure 1, have more calcareous shale above the upper key bentonite than either section 11 or section 20 , and one has more than section 44 . The change from calcareous to noncalcareous shale is gradual and varies in stratigraphic position from section to section and even from place to place on the same exposure. In several sections, rusty-weathering discoidal noncalcareous to slightly calcareous concretions are present through 10 to 30 feet of shale beginning 14 to 42 feet above the upper key bentonite. Despite its thickness, this concretionary interval is not present in all sections.

The shale is noncalcareous from the top of the calcareous shale interval just described to the base of the Fox Hills Sandstone. It is characterized by fairly numerous but not very persistent concretion horizons and by a very few thin bentonites. One fairly persistent bentonite $11 / 2$ to $13 / 4$ inches thick is present between 60 and 70 feet above the upper key bentonite in section $27 \mathrm{~A}$ and in several sections not shown in figure 4 . The contact between the Pierre Shale and the Fox Hills Sandstone is considered to be at 103 feet above the top of the Mobridge Member in section $27 \mathrm{~A}$ on the basis of a lithologic change from silty shale to clayey silt and on a color change from brownish-gray shale to grayishbrown silt. Both grain size and color changes are gradational, and the choice of an exact level for the contaci was arbitrary. Correlation between sections $27 \mathrm{~A}$ and 31 is based on the Pierre-Fox Hills contact and must be considered approximate. In section 31 the change from sility shale to clayey silt, which is again gradational, was used to delimit the contact. As thus correlated, the concretion horizons in these two sections are not well matched, presumably because of a lack of lateral persistence.

The Fox Hills Sandstone in section 31, where 74 feet of it is exposed, is a clayey silit containing a few interbeds of silty shale and shale. In section $27 \mathrm{~A}$, most of the 39 feet of exposed Fox Hills is shale; only the lower $61 / 2$ feet is clayey silt. This lithology is not typical of the lower part of the Fox Hills in more easterly exposures and must be due to facies changes within the lower part of the Fox Hills, assuming that the PierreFox Hills contact recognized here is correct.

\section{STRATIGRAPHIC SEQUENCE ALONG THE GRAND RIVER}

The lowest sections measured along the Grand River: (see figs. 1, 5) are along a railroad cut in the vicinity of Wakpala, S. Dak., and begin in calcareous shale. In these sections, the lower 15 feet of shale generally contains white to buff-weathering calcareous concretions; in some sections these concretions continue to $80 \mathrm{fee}^{+}$ above the base. A single bentonite bed 1 to 3 inche thick, interpreted as correlative with the lower key bentonite in the Moreau River sections, is present in tha lower part of the sequence. This single bed occurs 49 feet above the base of section 41 , and farther to tha north, it occurs 39 feet above the base of section 42 and just above the base of section 44 . In section 37 , a short distance south of section 41 , its level is occupied by a 4- to 6-inch-thick layer of indurated very calcareous marl 48 feet above the base of the section. The interval between the lower and upper key bentonites in section 44 is characterized by a lack of bentonites, few concre. tions, generally slight and sporadic calcareousness, and scattered pods and blebs of melanterite(?). This interval is capped by a 4- to 12-inch-thick bentonite in siv sections, three of which are illustrated in figure 5. This bed was correlated with the upper key bentonite of th? Moreau River stratigraphic sequence. Calcareous sha]? persists from 4 to 10 feet above this bentonite in all six sections before giving way to noncalcareous shale.

About 192 feet of noncalcareous shale is present between the base of the Fox Hills Sandstone and the ton of the calcareous shale. Correlation of the sections which consists only of rocks from this interval was difficult because of the lack of marker beds. A few thin bentonite beds, some of which contain small subspher:cal bladed barite concretions, occur but do not persist laterally. Section 49, which is correlated with section 44 by means of the upper key bentonite, contains a 1-inch bentonite 54 feet above the upper key bentonits. This 1-inch bentonite has been correlated with a 1/4-inch bentonite 9 feet above the base of section 54 , but thers are no supplementary criteria, either from these or irtervening sections, to substantiate this correlation.

Sections 54, 53, and 52, all within half a mile of each other, were very difficult to correlate. Correlations wer's made by elevation as determined by sighting through a hand level because none of these sections contains key horizons which could be recognized confidently in other: sections. Silt and sand content rapidly increases, begining about 32 feet above the base of section 52, and clayey, sandy silt predominates at 40 feet above the base of the section. The contact between the Pierre Shale and the Fox Hills Sandstone is arbitrarily placed 40 feet above the base of this section. 
About 23 feet of silty noncalcareous shale is exposed below the Pierre-Fox Hills contact in section 50 where the contact has been placed just below a concretion horizon containing the characteristic basal Fox Hills ammonite Discoscaphites nicolleti. The rock is a silty clay for about 7 feet above this level before grading into siltstone.
About 22 feet of the Fox Hills Sandstone is exposed in section 52, and about 71 feet is exposed in section 50 . The Fox Hills in these two sections is predominantly unstratified sandy, clayey silt. Because detailed study of the stratigraphy of the Fox Hills Sandstone was outside the scope of this study, no attempts at correlation or member subdivision were made.

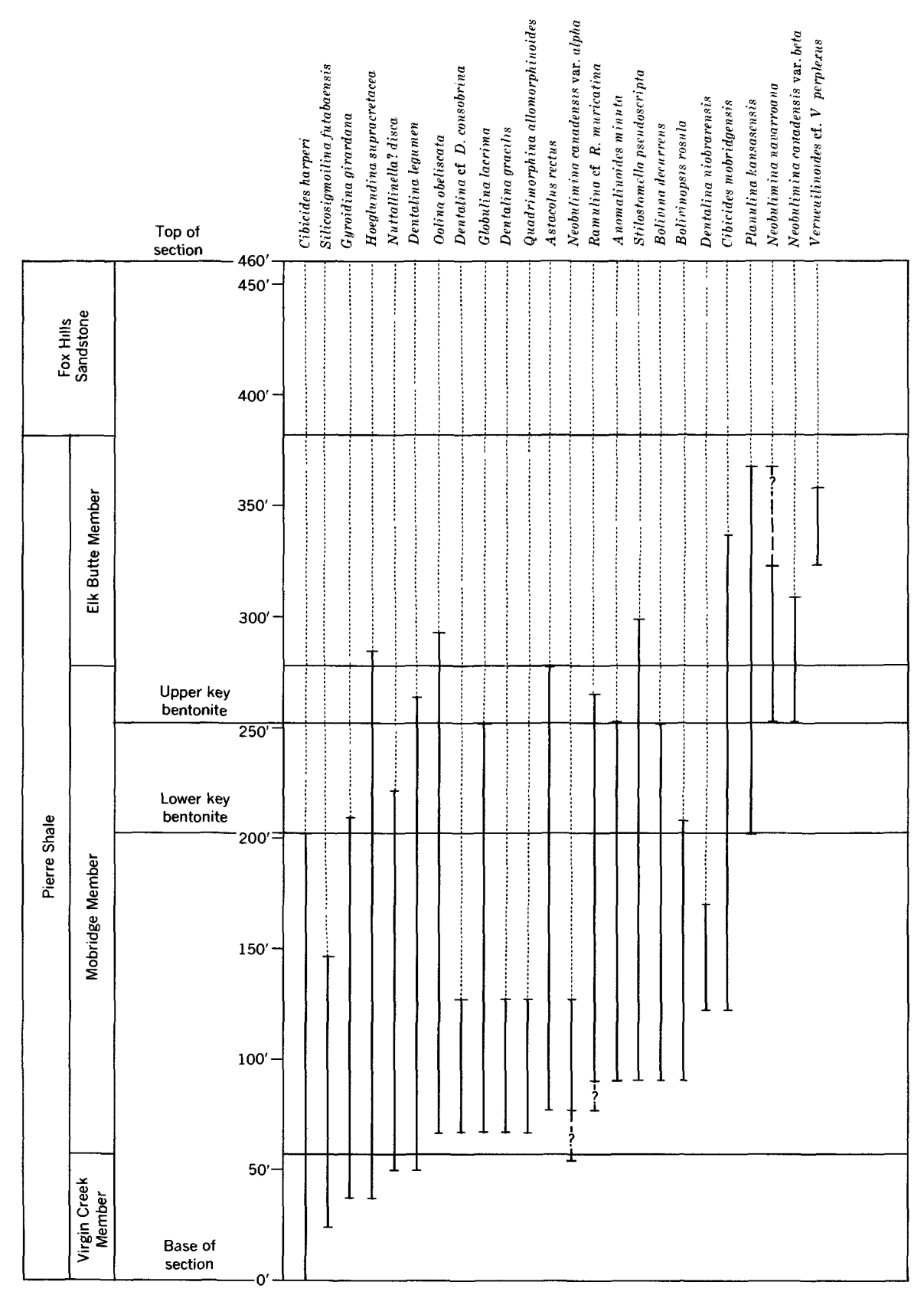

Figure 2.-Ranges of Foraminifera useful in local correlation of the upper part of the Pierre Shale and lower part of the Fox Hills Sandstone relative to the composite stratigraphic sequences along the Moreau River. Thickness of the interval between the lower and upper key bentonites is the average of the interval's thickness at localities 7, 11, and 13. Thickness of the interval between the upper key bentonite and the top of the Mobridge Member is the average of the interval's thickness at localities $7,11,13,20$, and 27 . 
FORAMINIFERA, STRATIGRAPHY, PIERRE SHALE, FOX HILLS SANDSTONE, S. DAK.

\section{RELATIONSHIP OF THE SEQUENCES}

The relationship between the generalized stratigraphic sections along the valleys of the Grand and Moreau Rivers is shown in figure 6. In the Moreau sequence the lower 58 feet is noncalcareous shale of the Virgin Creek Member. This grades upward into generally calcareous and more readily decomposed shale of the Mobridge Member that persists for about 218 feet.
The calcareous Mobridge shale grades upward into noncalcareous, slightly fissile shale of the Elk Butte Member. Approximately 103 feet of noncalcareous Elk Butte shale lies between the highest calcareous shale and th? base of the Fox Hills Sandstone. Bentonite beds ar? common in the Virgin Creek and Mobridge Members: Two of these, designated the lower and upper key bentonites, are more widespread and generally thicker

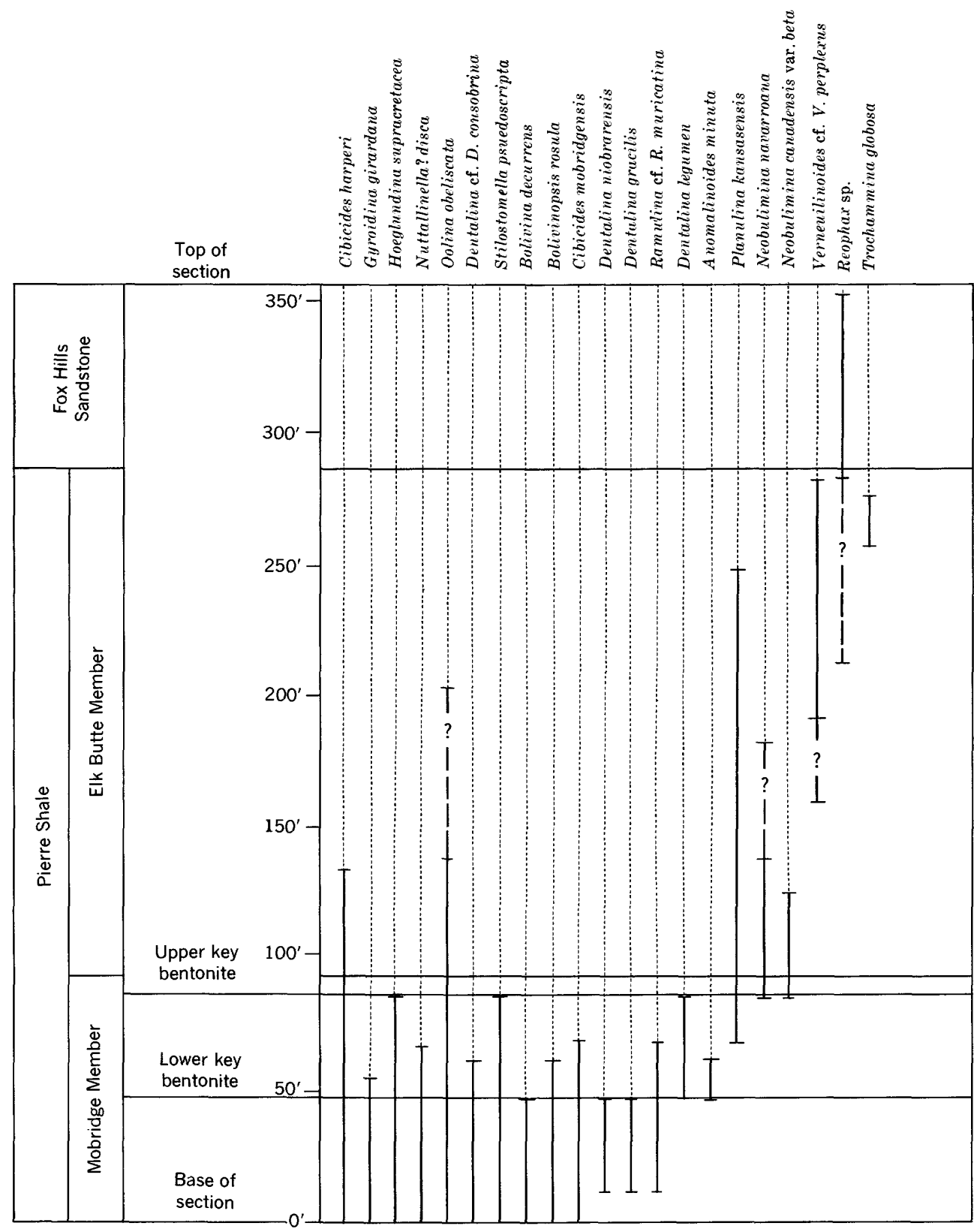

FiguRE 3.-Ranges of Foraminifera useful in local correlation of the upper part of the Pierre Shale and lower part of the Fox Hills Sandstone relative to the composite stratigraphic sequences along the Grand River. Thickness of the interval between the upper key bentonite and the top of the Mobridge Member is the average of the interval's thickness at localities 44 and 49. 
than the others. These two bentonites were useful for correlation of both near and distant sections and were used as reference levels for the stratigraphic work. On a more local scale, other bentonites and laterally persistent features were also utilized for correlation.

Calcareous shale of the Mobridge Member occurs at the base of the Grand River sequence and persists upward for about 93 feet before grading into the noncalcareous shale of the Elk Butte Member. The noncalcareous Elk Butte shale is about 192 feet thick and
SHALE, FOX HILLS SANDSTONE, S. DAK.

grades upward into the silts and sands of the Fox Hills sandstone. Bentonite beds are much less common in the Grand River sections, but both the upper and lower key bentonites were recognized.

In the Moreau River sequence, and to a greater extent along the Grand River, sections above the upper key bentonite were difficult to correlate because of the lack of persistent bentonites and the general unreliability or scarcity of concretion horizons. Foraminifera were of little help because only a few long-ranging and non-

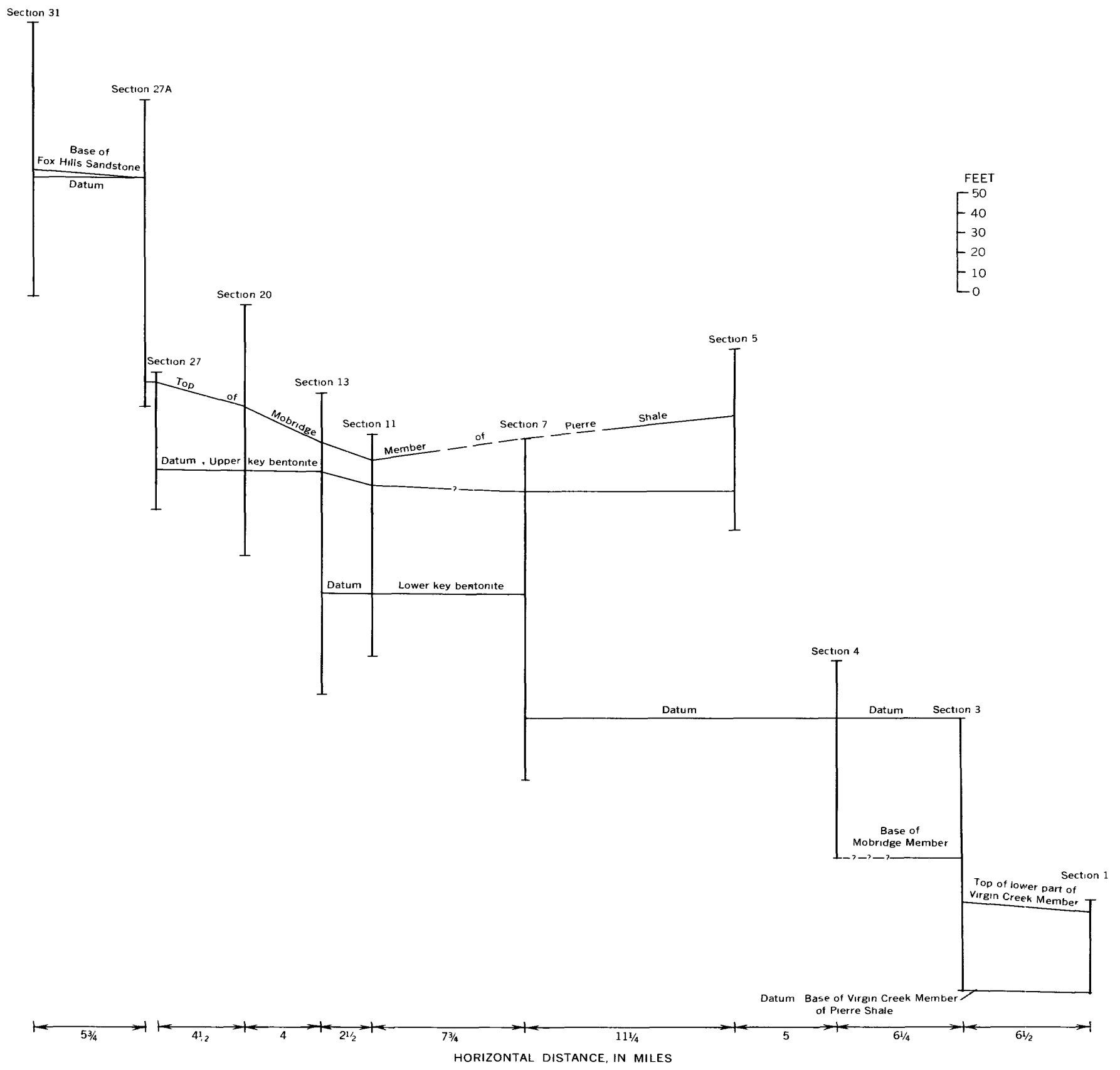

FIGURE 4.-Correlation chart of stratigraphic sections along the Moreau River and environs (see fig. 1 for location of sections). 
diagnostic species are present, particularly in the upper part of the Elk Butte Member.

The upper key bentonite, because of its importance in relating the two stratigraphic sequences, is discussed in more detail. This bentonite varies in thickness from 0 to 16 inches in the Moreau River valley and occurs in sections as much as 27 miles apart. It thins considerably to the southeast and is absent in section 7 where its level is occupied by a 3 - to 4 -foot bed of shale heavily interlaced with melanterite(?). In the Grand River valley this bentonite varies in thickness from 4 to 12 inches and occurs in section as much as 18 miles apart.
Upland lacking any adequate exposures of Pier'e Shale extends for 21 miles and separates the two closest sections in the valleys of the Moreau and Grand Rivers that include the upper key bentonite (sections 5, and 49 , figs. 4, 5). The identity of this bentonite along both rivers is accepted because it is the highest thick and persistent bentonite beneath the Fox Hills Sandstone and because it is the only thick bentonite in the upper part of the Mobridge Member. In the Moreau River sections it is usually 10 to 30 feet below the change from calcareous to overlying noncalcareous shale, and in the Grand River sections it is 4 to 10 feet below this chang:.

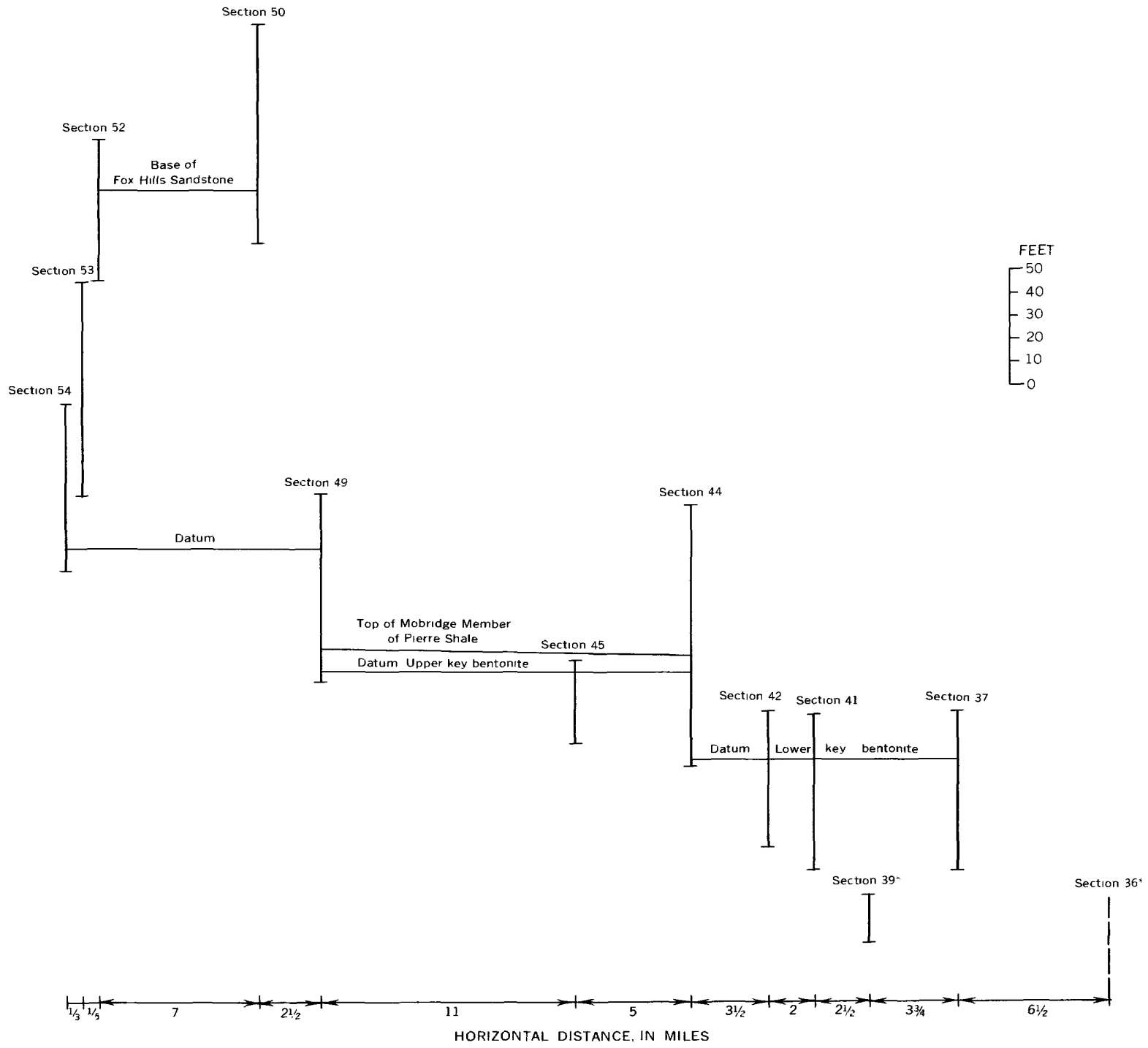

FIgURE 5.-Correlation chart of stratigraphic sections along the Grand River and environs (see fig. 1 for location of sections). *Indicates section could not be correlated on the basis of lithology or key beds. Foraminiferal ranges indicate section is between 0 and 150 feet below the lower key bentonite. Dashed line indicates partly exposed section.

323-073 0-69-2 


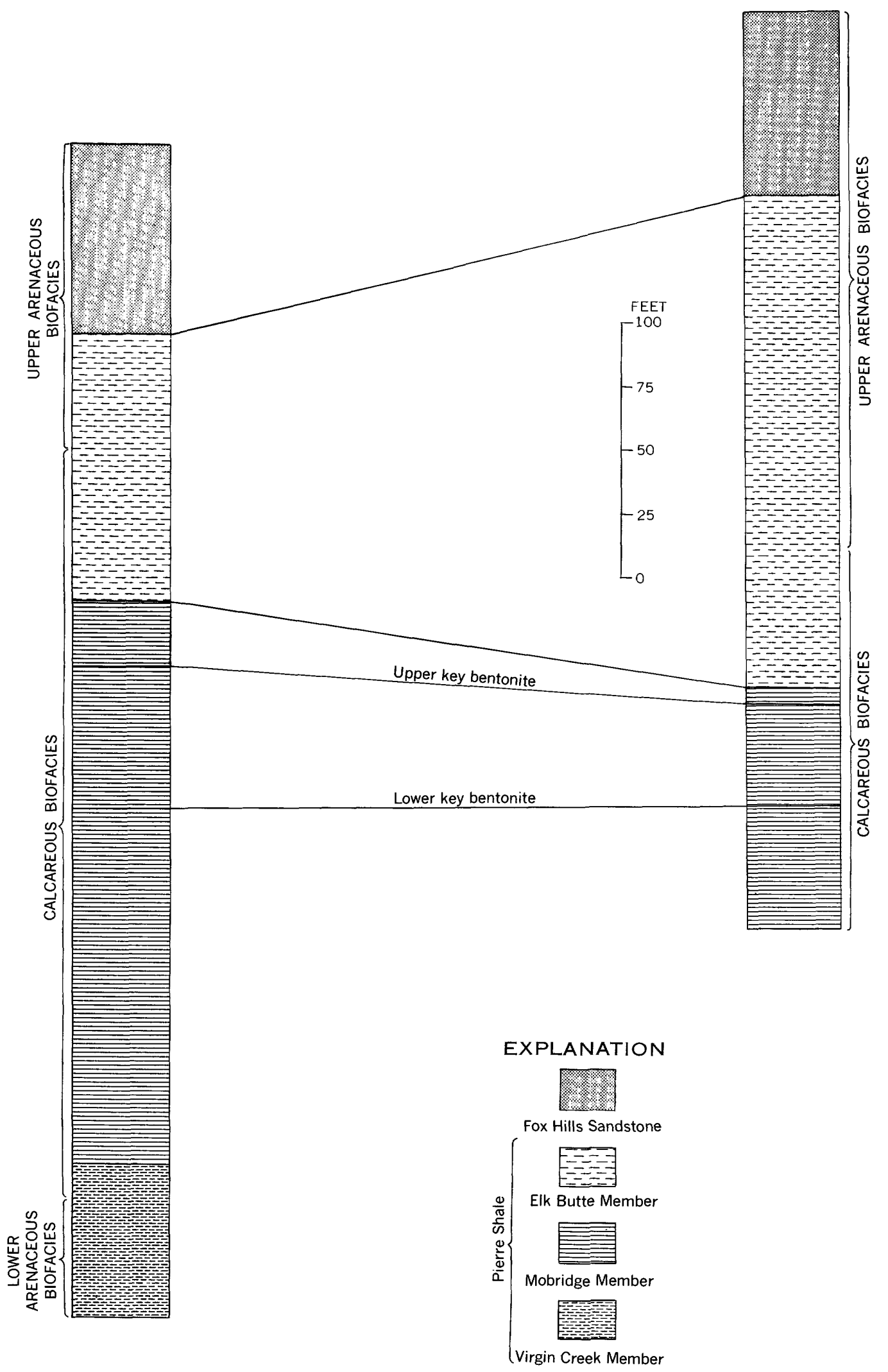

FIGURE 6.-Foraminiferal biofacies in composite stratigraphic sections of the upper part of the Pierre Shale and lower part of the Fox Hills Sandstone along the valleys of the Moreau (left) and Grand (right) Rivers. 
The lowest and highest occurrences of most species of Foraminifera match well between the two stratigraphic sequences when they were correlated on the basis of the upper key bentonite. Thus the faunal evidence, although not conclusive, supported the correlation.

Matching of the Grand and Moreau stratigraphic sequences based on the upper key bentonite placed the 3 -inch bentonite of the Grand River stratigraphic sequence, which is the thickest and most persistent bentonite between the upper key bentonite and the base of the sequence, in approximately the same stratigraphic position as the lower key bentonite of the Moreau sequence, and consequently they are considered to be the same bed.

\section{BIOSTRATIGRAPHY}

\section{REGIONAL CORRELATION}

Macrofossils, which are very rare in the upper part of the Pierre Shale, have traditionally served as the means of regional correlation in the western interior. The intensive studies of the cephalopods of the western interior by W. A. Cobban have made them the most useful group for correlation within the region and have permitted interregional correlation. The cephalopod species Baculites clinolobatus Elias, present in the lower and middle parts of the Mobridge Member, can be related to Cobban and Reeside's (1952) zonal scheme. Aocording to Cobban (1958, p. 114), B. clinolobatus is the immediate descendant of $B$. grandis Hall and Meek. $B$. grandis occurs in beds correlative with beds of probable early Maestrichtian age in Europe and with beds in the upper one-third of the Navarro Group of the Gulf Coast. Clearly, B. clinolobatus represents a slightly later timespan than does $B$. grandis.

The study of Foraminifera in the western interior stands in contrast to the study or cephalopods and some other macrofossil groups in that no systematic attempt has been made to discover the occurrence and distribution of foraminiferal species. Once this is done, there is no reason Foraminifera should not be as useful in regional correlation within the western interior as macrofossils currently are. The planktonic Foraminifera are considered to be most useful for interregional correlation. Unfortunately, the four planktonic species found in the upper part of the Pierre Shale were of little use in precise correlation because their ranges are long or poorly known. Benthonic Foraminifera, predominant in the upper part of the Pierre and lower part of the Fox Hills, are presently less useful than the planktonics in interregional correlation because of their much less finely divided age ranges. However, most of the benthonic species are present also in Cretaceous deposits of the Gulf Coast where their local ranges are well known. Therefore, it is possible to compare the upper part of the Pierre and the lower part of the Fox Hills forminiferal faunas with those of the Gulf Coast.

Of the 86 species of Foraminifera positively or tentatively identified from the upper part of the Pierro Shale and the lower part of the Fox Hills Sandstone, seven are new. Sixty-two were reported from the Cretaceous deposits of the Gulf Coastal Plain as summarized by Cushman (1946). The remaining 17 species either were not noted by Cushman or have not been definitely. identified from the Gulf Coastal Plain. $\mathrm{O}^{f}$ the 62 species in common, 15 occur only in beds of $\mathrm{Na}$ varro age, 15 occur only in beds of Taylor and Navarro ages, 19 range from Austin to Navarro age, six occur only in beds of Taylor age, five occur only in beds of Austin and Taylor ages, and two occur only in beds of Austin age. The stratigraphic occurrences of these species in the Gulf Coast deposits are illustrated in table 1. The correlation chart of Cobban and Reeside (1952) indicates that the Navarro-Taylor boundary in the westem interior is well below the base of the Virgin Creet? Member of the Pierre Shale. Therefore, the presence of 13 species of Foraminifera in the Pierre faunas which do not range into Navarro age beds in the Gulf Coast, according to Cushman (1946), deserves attention. These 13 species are listed below :

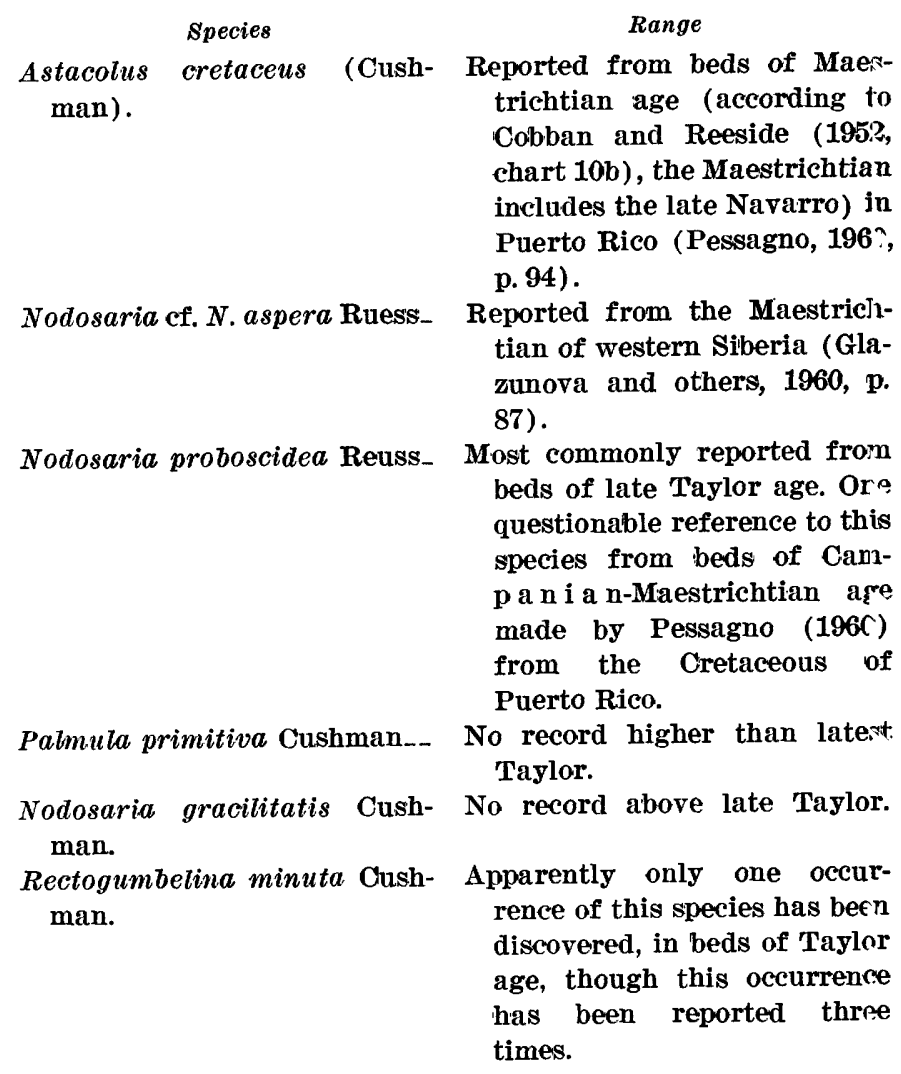


Species

Gaudryina bentonensis (Car- Reported by Cushman and Renz man).

Heterohelix pulchra (Brot- Reported from beds of Maezen).

Robulus taylorensis (Plum- Reported six times from beds of mer).

Spiroplectammina laevis (Roemer) cretosa Cushman.

Nodosaria fusula Reuss_

Planulina kansasensis Morrow.

Pleurostomella nitida Mor- This species has been reported row.

To summarize the occurrence data given above, of the 13 species which do not occur in beds of Navarro age in the Gulf Coast Cretaceous deposits, five species have been reported in other areas from beds correlative with the Navarro, one species has been reported with question from beds correlative with the Navarro, at least two species (Rectogumbelina minuta and Pleurostomella nitida) have been reported too few times to assign any age importance to their occurrence, and five species have no previous record of occurrence in beds of Navarro or equivalent age. Of these five species, four are represented by a relatively few specimens in the upper part of the Pierre Shale (Palmula primitiva is represented by one specimen) but the fifth species, Planulina kansasensis, is one of the more abundant species in the upper part of the stratigraphic sequence.

The 15 species present in the upper part of the Pierre Shale which are reported only from beds of Navarro age in the Gulf Coast deposits are deserving of the same

kind of scrutiny in order to determine which may be considered to be reliable indices of Navarro age. The ranges of each of these species in areas other than the Gulf Coastal Plain are considered below :

Species

Astacolus jarviscllus Mello, new name.

Cibicides harperi (Sandidge) -

Neobulimina

(Cushman).

Bulimina reussi Morrow navarroensis Cushman and Parker.

Astacolus navarroanus (Cushman).

Astacolus dissonus Plummer-

Bolivina decurrens (Ehrenber'g).

Gaudryina watersi (Cushman).

Loxostoma gemma (Cushman).

osangularia navarroana (Cushman).

Robulus spissocostatus Cushman.

Bulimina arkadelphiana Cushman and Parker.

Tappanina costifera (Cushman).

Marginulina curvatura Cushman.

Lagena sulcata (Walker and Jacob) semiinterrupta W. Berry.

\section{Range}

Most references are from beds of Navarro age or equivalents, but this species has been reported from beds as old as Coniaciar and Santonian in California (Trujillo, 1960, p. 317).

No reports of this species from rocks older than Navarro age.

Do.

Do.

Do.

Do.

Do.

Do.

Do.

Do.

Do.

Do.

Do.

Reported from the Rumoi coal fields, Hokkaido, Japan (Fukuta, 1957, p. 12) and from beds containing Foraminifera of Austin, Taylor, and Navarro ages. Fukuta did not correlate the Rumoi beds with either Austin, Taylor or Navarro but irstead compromised by calling them probably Campanian. Specimens questionably referred to this species by Rompf $(1960$, p. 33$)$ are from the Cenomanian of Germany.

There is no publish $\cong d$ report of this species occurring in beds older than Navarro, but Cushman (194\&a, p. 256) stated that the species occurs in beds of Navarro and Taylor ages.

Of the 15 species present in the upper rart of the Pierre Shale and restricted to beds of N'avarro or 
younger ages in the Gulf Coast deposits, 12 have never been reported from pre-Navarro rocks. There is some doubt whether two other species range lower than Navarro, and one species has been positively identified from older rocks. Of the 12 species apparently restricted to beds of Navarro age, two (Tappanina costifer $a$ and Osangularia navarroana) have been reported from only a few samples, and thus their ranges cannot be considered well known.
In summary, in the upper part of the Pierre Shale there are at least five well-established species whicl have not been reported from beds of Navarro or equivalent age, and at least 10 which have not been reported from beds older than Navarro. This indicates a Navarro age for the upper part of the Pierre Shale, in accord with the macrofossil evidence, based on a balance of evidence. Perhaps the presence of Taylor species indicates a lower Navarro equivalence for the upper part.

TABLE 1.-Gulf Coast stratigraphic distribution (after Cushman, 1946) of Foraminifera found in the upper part of the Pierre Shale and lower part of the Fox Hills. Sandstone

[Synonyms under which Cushman recorded these species are given in parentheses]

\begin{tabular}{|c|c|c|c|c|c|c|c|c|c|c|c|c|c|c|c|c|c|c|c|c|c|c|c|c|}
\hline \multirow[b]{2}{*}{ Fossil } & \multicolumn{7}{|c|}{ Austin age } & \multicolumn{8}{|c|}{ Taylor age } & \multicolumn{9}{|c|}{ Navarro age } \\
\hline & 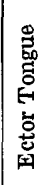 & 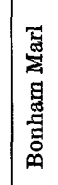 & 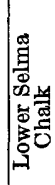 & 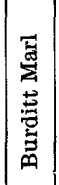 & 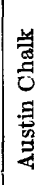 & 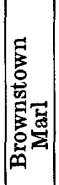 & 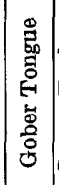 & 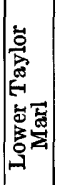 & 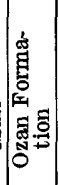 & 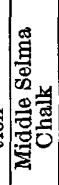 & 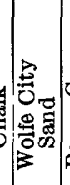 & 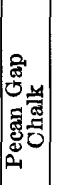 & 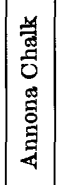 & 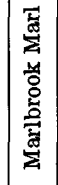 & 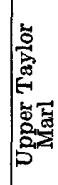 & 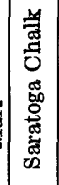 & 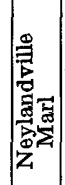 & 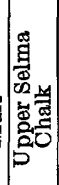 & 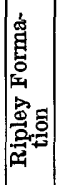 & 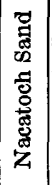 & 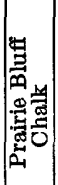 & 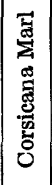 & 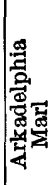 & 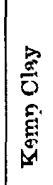 \\
\hline tacolus dissonus (Planularia disson & & & & & & & & & & & & & & & & & & & & $x$ & $x$ & $x$ & & $x$ \\
\hline $\begin{array}{l}\text { Astacolus jarvisellus (Marginulina jarr } \\
\text { Astacolus navarroanus (Marginulina } n\end{array}$ & & & & & & & & & & & & & & & & & & & & 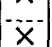 & & $x$ & $x$ & \\
\hline Bolivina de & & & & & & & & & & & & & & & & & & & & $x$ & . & $x$ & $x$ & \\
\hline kade'phiana & & & & & & & & & & & & & & & & & & & & & & & $\hat{x}$ & \\
\hline $\begin{array}{l}\text { Bulimina reussi navarroensis (including Buliminella carseyae } \\
\text { var. plana) }\end{array}$ & & & & & & & & & & & & & & & & & $x$ & & $x$ & & $x$ & $\times$ & & $x$ \\
\hline $\begin{array}{l}\text { Cibicides harperi } \\
\text { Gaudryina vatersi }\end{array}$ & & & & & & & & & & & & & & $\cdots$ & & & & $\bar{x}$ & $-\bar{x}$ & $x$ & $\underset{x}{x}$ & $\stackrel{x}{x}$ & $\bar{x}$ & $\frac{x}{x}$ \\
\hline Lagena sulcata semiinterrupta... & & & & & & & & & & & & & & & & & & $\stackrel{x}{x}$ & $x$ & $x$ & & & & \\
\hline Loxostor & & & & & & & & & & & & & & & & & & & & $x$ & $x$ & & 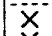 & $x$ \\
\hline Marginulina cur & & & & & & & & & & & & & & $\cdots$ & & & & $\cdots$ & & & $\cdots$ & $\underset{x}{x}$ & $x$ & 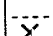 \\
\hline $\begin{array}{l}\text { Neoou } \\
\text { Osang }\end{array}$ & & & & & & & & & & & & & & & & & & & & & $\bar{x}$ & $x$ & $\bar{x}$ & $\frac{Y}{x}$ \\
\hline Robult & & & & & & & & & $\cdots$ & & & $\cdots$ & & $\cdots$ & & & -.. & $\cdots$ & $x$ & & $\hat{x}$ & $\hat{x}$ & $\hat{x}$ & 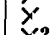 \\
\hline $\begin{array}{l}\text { Tappanina costifera (Bolivinita costifera) } \\
\text { Astacolus cretaceus (Marginulina cretacea) }\end{array}$ & & & & & & & $\ldots$ & $x$ & $\ddot{x}$ & & $\ldots$ & $x$ & & $x^{-}$ & $x$ & & $x$ & & & .... & .... & & .... & $\begin{array}{ll}\lambda ? \\
\cdots+.\end{array}$ \\
\hline Bulimina prolixa & & … & & & & & & & & $x$ & & & & $\underset{x}{x}$ & $\underset{x}{x}$ & & $\underset{x}{x}$ & & $x$ & & & $x$ & & $\cdots$ \\
\hline Erus (including range of var. $c$ & .. & ...- & & & & & $\cdots$ & $x$ & $\bar{x}$ & $x$ & $\underset{x}{x}$ & $\underset{v}{x}$ & $\underset{x}{x}$ & $x$ & $x$ & $x$ & $\dot{x}$ & $x$ & $x$ & $x$ & $x$ & $\mathrm{x}$ & $x$ & $\cdots$. \\
\hline Dentalina ef. $D$. & & & & & & & & & $x$ & $\bar{x}$ & & & & & $\begin{array}{l}x \\
x\end{array}$ & $\ldots$. & & & $\bar{x}$ & $\ldots$ & $\ldots .$. & $\bar{x}$ & $\ldots$ & $\because-$ \\
\hline Dentalina pert & & 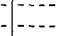 & & & & & & & & & & & $\cdots$ & .... & $\hat{x}$ & & $\cdots \cdot$ & $x$ & $\boldsymbol{\lambda}$ & & .... & & -..- & \\
\hline & & & & & & & & & & & & & & .... & $x$ & & $\ldots$ & $x$ & & & .... & -.. & .... & .... \\
\hline iciana & & & & & & & $\ldots$ & $x$ & $\underset{x}{x}$ & $x$ & $x$ & $x$ & $x$ & $\cdots$ & $x$ & $\ldots$ & ... & & $\underset{x}{x}$ & $\cdots$ & $\cdots$ & $\cdots$ & $\cdots$ & $\cdots$ \\
\hline sa (Guembelina olobu & - & $\cdots$ & & & & & & $x$ & & - & $x$ & & & $x$ & & $\bar{x}$ & $x$ & $x$ & $\frac{x}{x}$ & $x^{-}$ & $x$ & $\bar{x}$ & $x$ & $\%$ \\
\hline Hetero & & & & & & & & $x$ & $\bar{x}$ & $\cdots-$ & $x$ & $x$ & $x$ & … & $\hat{x}$ & & $\ldots$ & $\hat{x}$ & $\hat{x}$ & $\ldots$ & .... & $\hat{x}$ & $\hat{x}$ & r \\
\hline racretacea (Epistomina caracolla) & & .... & $\cdots$ & & $\cdots$ & $-\ldots$ & 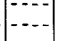 & $\hat{x}$ & 凡 & 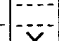 & $\hat{x}$ & $\hat{x}$ & 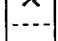 & -...- & $\hat{x}$ & $\cdots$ & $x$ & $\hat{x}$ & $\widehat{x}$ & $x$ & $\cdots$ & $\hat{x}$ & $\hat{n}$ & $\%$ \\
\hline Palmul & & $\cdots$ & & & & & & & $-\cdots$ & $x$ & & & & $\cdots$ & $\begin{array}{l}x \\
x\end{array}$ & $|-\cdots|$ & x... & & & $x$ & $x$ & $x$ & $\ddot{x}$ & 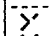 \\
\hline & $\cdots$ & 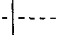 & $\ldots$ & & $\cdots$ & $\cdots$ & & & $\cdots$ & $x$ & & $\underset{x}{x}$ & - $\cdots$ & $x$ & $\hat{x}$ & $\cdots$ & $\cdots-$ & $x$ & $\underset{x}{x}$ & $\cdots$ & $x$ & $\underset{x}{x}$ & $x$ & $\%$ \\
\hline $\begin{array}{l}\text { Ammodiscus cr } \\
\text { Bolivinopsis rod }\end{array}$ & $\ldots . . .>2>3$ & $\ldots$. & $x$ & $x$ & $x$ & $\ddot{x}$ & $\underset{x}{x}$ & $\begin{array}{l}x \\
x\end{array}$ & $\cdots$ & $\ddot{x}$ & $x$ & $\begin{array}{l}x \\
x \\
\end{array}$ & $\begin{array}{l}x \\
x\end{array}$ & $\bar{x}$ & $\begin{array}{l}x \\
x\end{array}$ & $\cdots$ & $x$ & $x$ & $\begin{array}{l}x \\
x\end{array}$ & $\cdots$ & $x$ & $\begin{array}{l}x \\
x\end{array}$ & $\cdots$ & $\cdots$ \\
\hline Bullim & $\cdots$ & 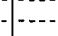 & $\hat{x}$ & & & & & $\hat{x}$ & $\cdots$ & & $\hat{x}$ & $\hat{x}$ & $\ddot{x}$ & $\underset{x}{x}$ & $\hat{x}$ & $x$ & $\underset{x}{x}$ & 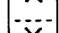 & $\ddot{x}$ & $\cdots$ & $\ddot{x}$ & & & \\
\hline $\begin{array}{l}C i b i c i \\
D\end{array}$ & & ${ }^{-} \bar{x}^{-}$ & $\underset{x}{x}$ & & & & & $\underset{x}{x}$ & & $x$ & & & & $x$ & & & $x$ & $x$ & & & - & & & 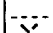 \\
\hline $\begin{array}{l}\text { Denta } \\
\text { Denta }\end{array}$ & & $x$ & $\begin{array}{l}x \\
x \\
x\end{array}$ & $\cdots$ & $\underset{x}{x}$ & $\begin{array}{l}x \\
x\end{array}$ & $\begin{array}{l}\times \\
\times\end{array}$ & $\begin{array}{l}x \\
x\end{array}$ & $-\cdots \cdot \mid$ & $-\bar{x}$ & $\cdots$ & $\begin{array}{l}x \\
x \\
x\end{array}$ & $\begin{array}{l}x \\
x\end{array}$ & $\cdots$ & $\begin{array}{l}x \\
x\end{array}$ & $x$ & $x$ & $x$ & $\bar{x}$ & $\cdots$ & $\stackrel{x}{x}$ & $\stackrel{x}{x}$ & \begin{tabular}{|l}
$x$ \\
$x$
\end{tabular} & $>$ \\
\hline Denta & & $\ldots$ & & & & & $\hat{x}$ & & $\cdots$ & & & $\hat{x}$ & $\hat{x}$ & $x$ & $\hat{x}$ & & & $\hat{x}$ & & & & & & \\
\hline othia stephen & & & & $\cdots$ & $x$ & $\ldots$ & $x$ & $x$ & $x$ & $\because$ & $x$ & $x$ & $\ddot{x}$ & $\cdots$ & $\underset{x}{x}$ & $x$ & .... & $-\ddot{x}^{-}$ & & $\because$ & בَ & & & $\cdots$ \\
\hline$a$ (including range of var. $h$ & $\ddot{x}$ & $\cdots$ & $\underset{x}{x}$ & $x$ & $\begin{array}{l}x \\
x\end{array}$ & & & $\begin{array}{l}x \\
x\end{array}$ & $\mid \begin{array}{l}x \\
x\end{array}$ & $\begin{array}{l}x \\
x\end{array}$ & $x$ & $x$ & $x$ & $-\bar{x}$ & $\begin{array}{l}x \\
x\end{array}$ & $\begin{array}{l}x \\
x\end{array}$ & $x$ & $\stackrel{x}{x}$ & $\stackrel{x}{x}$ & $x$ & $\begin{array}{l}x \\
x\end{array}$ & $\underset{x}{x}$ & $x$ & $\cdots$ \\
\hline girardana & $\hat{x}$ & $\cdots$ & $\hat{x}$ & $\hat{x}$ & $\hat{x}$ & $\hat{x}$ & $\hat{x}$ & $\hat{x}$ & $\hat{x}$ & $\hat{x}$ & $\hat{x}$ & $\hat{x}$ & $x$ & $\ldots$ & $\hat{x}$ & $\hat{x}$ & $\hat{x}$ & $\hat{x}$ & $\hat{x}$ & $\cdots$ & -..- & $\hat{x}$ & $\cdots$ & $\because$ \\
\hline$p_{-1}$ & & & $x$ & & & & & $\begin{array}{l}x \\
x\end{array}$ & & $|x| x$ & $x$ & $x$ & & $\underset{x}{x}$ & $\begin{array}{l}x \\
x\end{array}$ & $\begin{array}{l}x \\
x\end{array}$ & $\underset{x}{x}$ & $\underset{x}{x}$ & $x$ & $x$ & $x$ & $x$ & $\bar{x}$ & \%- \\
\hline adensis & $\ldots$ & $\ddot{x}$ & $\hat{x}$ & $x^{-}$ & $x$ & $x$ & $x$ & $\hat{x}$ & |- & $\hat{x}$ & $x$ & $x$ & $x$ & $\hat{x}$ & $\hat{x}$ & $\because$ & $\hat{x}$ & $\hat{x}$ & $\hat{x}$ & & 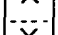 & $\underset{x}{x}$ & & $\because$ \\
\hline $\begin{array}{l}\text { Nodos } \\
\text { Palmu }\end{array}$ & & & $x$ & & & & & $x$ & $\underset{x}{x}$ & $\underset{x}{x}$ & $x$ & $\underset{x}{X}$ & & & $\underset{y}{x}$ & $\underset{x}{x}$ & $\underset{y}{x}$ & $x$ & $\times$ & $\overline{-}$ & $x$ & $\underset{x}{x}$ & $x$ & ${ }^{\prime}$ \\
\hline ohina allomorphinoides (Valoulineria allomophi- & & & & & & & & & & & & & & & & & & & & & & & & \\
\hline 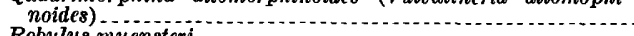 & & & & $x$ & $x$ & $x$ & $x$ & $x$ & - & & & & & & & & $\times$ & & $x$ & & $x$ & & & \\
\hline doenrin moudoertintet & & & $x$ & $x$ & $x$ & $x$ & $\hat{x}$ & $x$ & & & & $\cdots$ & $x$ & $x$ & $x$ & $\ldots$ & & $\ldots$ & $\ddot{x}$ & & & & & \\
\hline dosaria pseudoscripta) & & & & & & & $x$ & $x$ & & $x$ & $x$ & & $x$ & & $\underset{y}{x}$ & & $x$ & & & & $x$ & & & \\
\hline ginulina recta) & & & & - & & & & $x$ & & $\ldots .$. & $x$ & $\begin{array}{l}x \\
x\end{array}$ & $x$ & $x^{-}$ & $\stackrel{x}{x}$ & $\cdots$ & & & & & & 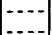 & $\cdots$ & $\ldots$ \\
\hline & & & & & & & .... & $\hat{x}$ & & & & & & & & & & & & & & & & \\
\hline & & & & & & & & & & $x$ & & $x$ & $\cdots$ & $x$ & $x$ & $-\ldots$ & ... & & & & & & ... & \\
\hline & & & & & & & & & & & & $x$ & $\ldots$ & $\mathrm{x}$ & $x$ & & & & & & & & & \\
\hline & & & & & & & & $\underset{y}{x}$ & & & 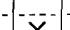 & & & & & & & & & & & & & \\
\hline uembelina ps & & $x$ & $x$ & $\bar{x}$ & & $\underset{x}{x}$ & $\bar{x}$ & $\underset{x}{x}$ & & & $x$ & $\underset{x}{x}$ & $\underset{x}{x}$ & & $\stackrel{x}{x}$ & & & & & & & & & ...- \\
\hline & & & $\hat{x}$ & $x$ & $\frac{x}{x}$ & $\vec{x}$ & $x$ & x & & & & & 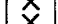 & $\ldots$ & & & & & & & & & & \\
\hline & & & & & & & & & & & $x$ & & & $\bar{x}$ & $x$ & & & & & & & & & \\
\hline & & & & & & & $x$ & $x$ & & & $\hat{x}$ & $\hat{x}$ & $\hat{x}$ & & $\hat{x}$ & & & & & & & & & \\
\hline & $x$ & $x$ & & & $x$ & $\hat{x}$ & $\boldsymbol{\lambda}$ & & & & & & & & & & & & & & & & & \\
\hline & & & & & & & & & & & & & & & & & & & & & & & & \\
\hline
\end{tabular}


of the Pierre Shale than has been suggested by correlation on the basis of cephalopods.

The 17 tentatively or firmly identified species, which are neither new or discussed above because of their lack of occurrence or confused age data in the Gulf Coast Cretaceous, may also be considered in discussing the age of the upper part of the Pierre Shale.

Species
Bathysiphon brosgei Tap-
pan (?).
Glomospira charoides (Jones
and Parker).
Haplophragmoides rota
Nauss and Haplophrag-
moides bonanzaensis
Stelck and Wall.
Spiroplectammina mor-
denensis Wickenden.

Verneuilinoides ef. $V$. perplexus (Loeblich).

Silicosigmoilina futabaensis Asano.

Trochammina globigeriniformis Cushman.

Trochammina globosa Bolin

Dentalina niobrarensis Loetterle.

Rectoglandulina appressa Loeblich and Tappan.

\section{Range}

According to Tappan (1962, p. $128)$, this species is present in beds of from Albian to late Campanian ages in northern Alaska.

Reported from beds of Barremian to Tertiary age.

Tappan (1962, p. 133, 134) reported both these species from beds of Turonian to late Campanian age.

In northern Alaska this species occurs in beds of Santonian and Campanian ages (Tappan, 1962, p. 140).

Reported twice from beds of Cenomanian age.

The range of this species has not been adequately established in Japan, where it was first discovered. Fukuta (1957, p. 10) felt that it is probably Campanian. The only previous reference of specimens to this species outside Japan was made by Trujillo (1960, p. 303), who recorded it from beds of Coniacian and Santonian ages in California.

Reported from beds that range in age at least from the Early Cretaceous to the latest Late Cretaceous and probably into the Tertiary.

The type reference (Bolin, 1956 , p. 289) is the only published reference to this species; Bolin reported it from beds of questioned Cenomanian age.

Reported twice from the Niobrara Formation of Coniacian-Santonian age.

The only reference (Loeblich and Tappan, 1955, p. 4) to this species is from the Upper Cretaceous of Arkansas and Texas where the species was reported from beds of Senonian, early Campanian, and Maestrichtian ages.
Species

Lagena sp. aff. L. quadralata Brady.

Ramulina cf. R. muricatina Loeblich and Tappan.

\section{Range}

The general morphologic similarity between the Pierre specimens and specimens of this Recent species is indicated by this designation.

Name was erected to replace the name Ramulina aculeata Wright. $R$. muricatina has only been reported from the Late Cretaceous, mostly from beds of Taylor age, but with some occurrences of Austin age, according to Cushman (1948a, p. 257).

Bolivinoides decoratus Assigned a latest Campanian (Jones) australis Edgeh.

Eouvigerina aspera (Marsson) inflata Marie (?).

Rugoglobigerina ef. H. rugosa (Plummer)

Biglobigerinella biforaminata (Hofker) age by Edgell (1954, p. 71) and apparently an early Maestrichtian ago by Hiltermann (1963, takles 1, 2).

Noted once and designated of Late Cretaceous age.

There is taxonomic confusion surrounding this species. No generally accepted age limits have been dete"mined, but most records are from the Campanian and Maestrichtian. It has be?n reported from beds as old as Santonian.

Both the taxonomy and the range of this species are uncertain. It has most frequently been reported from beds of Maestrichtian age, with one reference to it from the Maestrichtian - Campanian boundary.

Of these 17 taxa, the subspecies Botivinoides decoratus australis is of special interest for correlation because it is a member of a group of species and subspecies which have been related phylogenetically and which are of rather limited geologic range. Its age is considered latest Campanian or early Maestrichtian, and it is the most precisely defined taxon, with respect to age, in the entire upper Pierre fauna. It occurs in tro samples from the upper part of the Pierre, one at 5 feet below and one immediately below the lower key bantonite in section 41 .

The foraminiferal evidence suggests that the upper part of the Pierre Shale is more likely of early than late Navarro age and that it is close to the CampanianMaestrichtian boundary. Cobban and Reeride (1952, chart 10b) questionably placed the CampanianMaestrichtian boundary within the Mobridge Member; this placement agrees well with the age indicated by B. decoratus australis. 


\section{COMPOSITION OF THE FAUNA}

A total of 101 species and subspecies of Foraminifera were found in the upper part of the Pierre Shale and lower part of the Fox Hills Sandstone. It was possible to identify 86 of these, at least tentatively, to the specific or subspecific level. Of these 86,17 taxa have arenacoous (agglutinated) or siliceous tests, and 69 have calcareous tests. Four species (Heterohelix globulosa, $H$. pulchra, Rugoglobigerina cf. R. rugosa, and Biglobigerinella biforaminata) are planktonic. In addition, several kinds of radiolarians, fish bones and scales, scolecodonts, rare sponge spicules, echinoid spines and ophiuroidea ossicles, several genera and species of ostracodes, and what appear to be crushed spore cases were recovered from the samples.

Relatively few genera and species of macrofossils were found. Specimens of Baculites occur sporadically from the base of the section to the level of the lower key bentonite. Linguloid brachiopods, the most numerous macrofossils found, occur from 20 feet below the lower key bentonite into the lower part of the Fox Hills Sandstone. Several species of pelecypods and gastropods occur in the Mobridge Member. Rare scaphitid ammonites were found at several levels, most commonly in the Mobridge Member. In addition, the plant fossil "Serpula" wallacensis Elias, also called the Indian-bead, and small crabs were found in limited numbers in the Virgin Creek Member.

In a discussion of the broad faunal relations of the western interior macrofossils, Cobban and Reeside (1952, p. 1025) stated: "In general, the faunas [of the Pierre shale] are similar to those found to the north, in Canada, and are not matched by closely similar assemblages to the south in part of the Taylor Marl and the Navarro Group of the Gulf region *** though enough forms are found to provide a rational correlation. Seemingly the Pierre faunas are boreal or largely endemic." More than three-fourths of the identified species of Foraminifera from the upper part of the Pierre Shale are also present in beds of the Austin, Taylor, and Navarro of the Gulf Coast, an indication that access to the southern seas was available. It may be possible to determine whether this access was constant or intermittent by studying the foraminiferal faunas in the middle and lower parts of the Pierre. In either case, the composition of the Pierre macrofauna indicates that, although conditions in the western interior were not favorable for most Gulf Coast macroinvertebrates, they were favorable for Gulf Coast foraminiferal species, at least during the time of deposition of the upper part of the Pierre Shale.

\section{PALEOECOLOGY}

PALEOGEOGRAPHIC SETTING

Tourtelot's (1962, p. 10) conception of the regioral paleogeography of the western interior during the time of deposition of the Pierre Shale is as follow "The Pierre Shale and equivalent rocks were deposited in and adjacent to a relatively narrow and shallow sea extending southward across the present western interior region of the United States. The sea probably was ccnnected at the north with world oceanic waters and at the south from time to time with the seas of the Gulf Coast. The eastern shore area of this sea has not been preserved and the Pierre rocks contain little evidence of its natu"e. It must have been made up, however, of rocks of Precambrian and Paleozoic age that probably formed a broad nearly stable lowland in the present midcontinent region. $* * *$ During much of Pierre time $* * *$ the western shore lay $* * *$ in what is now western Montana, eastern Idaho, central Utah, and perhaps central or eastern Arizona. Most of the land behind the shore was composed of preexisting sedimentary rocks, although cystalline rocks of Precambrian age were exposed in Colorado during Pierre time. Several centers of ccntemporaneous volcanic activity are known to have existed near the western shore in west-central Montana."

Reeside (1957) gave a detailed account of events occurring in the western interior during the Late Cretaceous and placed them in a broad regional paleogrographic and tectonic setting. His reconstructions of the events affecting the rocks presently under consideration are summarized as follows: The fine-grained sediment composing the Virgin Creek Member was deposited while the sea was making its last westward advanee, during late Campanian time (fig. $7 A$ ). Considerable volcanic activity is attested to by the numerous, though generally thin, bentonites which characterize this member. In the early Maestrichtian, a fairly steady eastward retreat of the strand line took place, during which time the calcareous shales of the Mobridge Member were deposited (fig. $7 B$ ). Reeside did not mention the Elk Butte Member, but presumably these beds were laid down as the shoreline continued to retreat eastward. The Fox Hills Sandstone of middle and late Maestrichtian age is composed of sediments deposited close to the shoreline and represents the culmination of this retreat (fig. $7 C$ ).

As the shoreline retreated eastward, the northern connection of the interior sea with world oceanic waters was broken. Correlation charts given by Cobban and Reeside (1952) indicate terrestrial conditions in Wyoming and Montana, the probable northern access of the Pierre sea during or immediately after the time of Baculites grandis. B. clinolobatus, a direct descendant 
FORAMINIFERA, STRATIGRAPHY, PIERRE SHALE, FOX HILLS SANDSTONE, S. DAK.

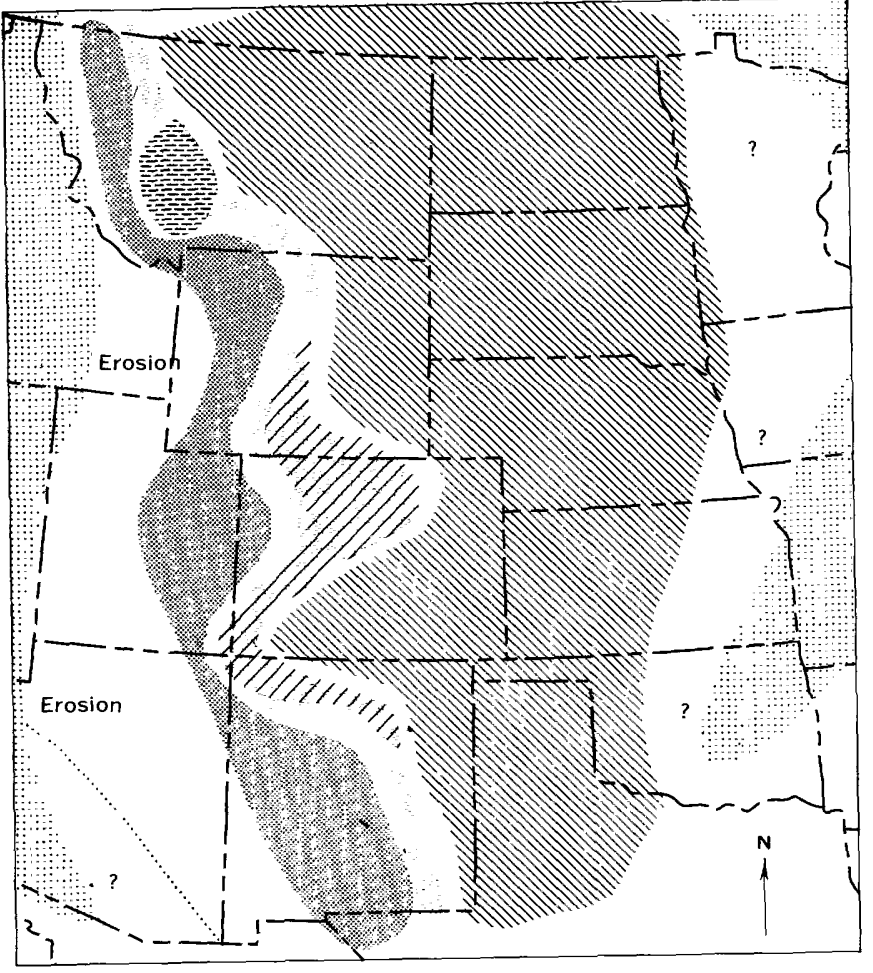

A

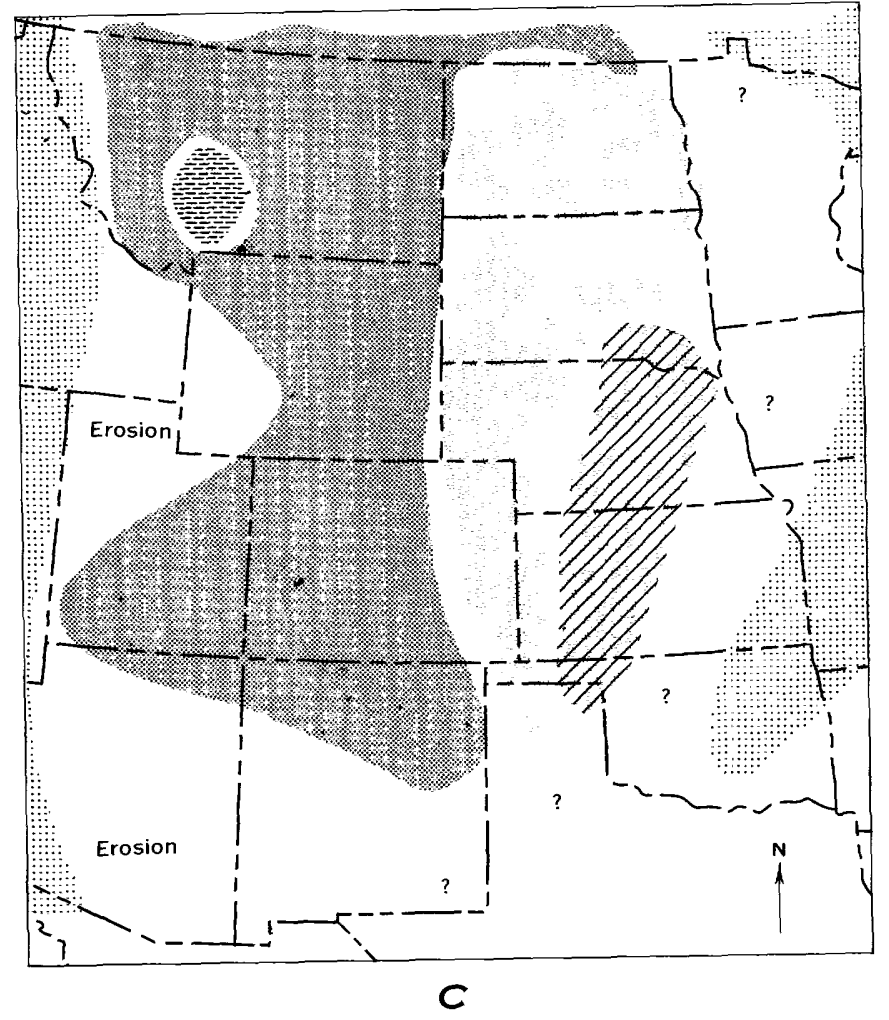

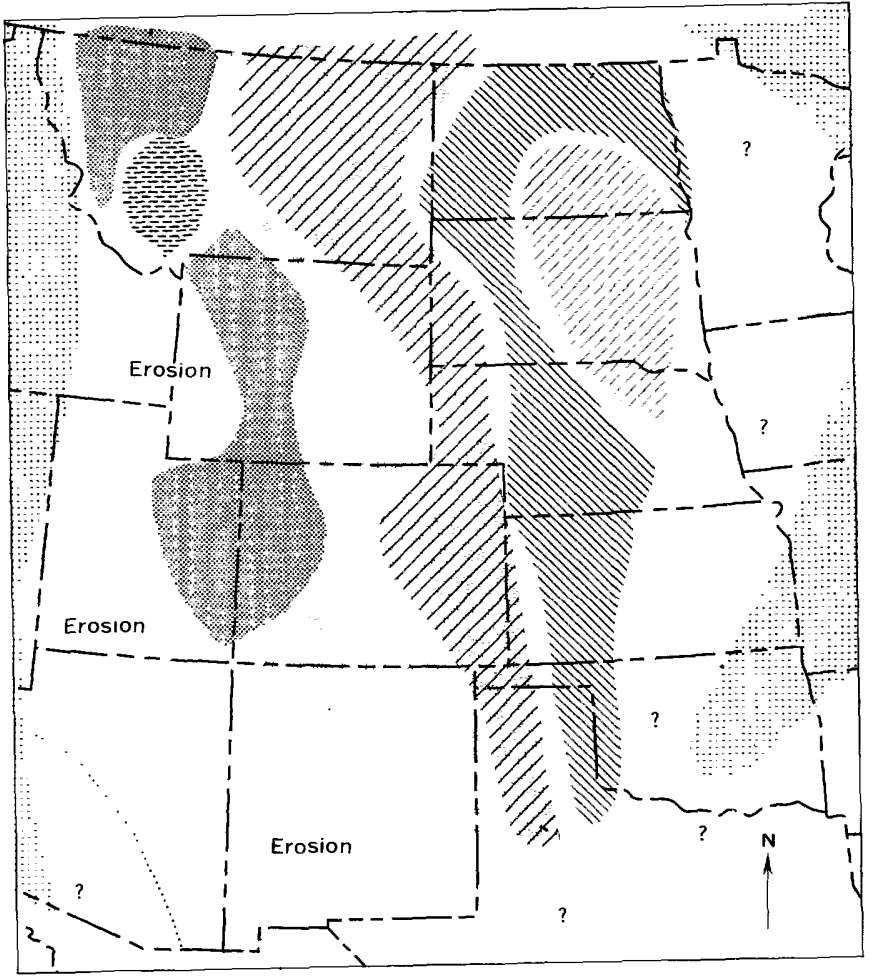

B

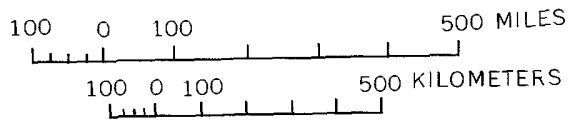

\section{EXPLANATION}

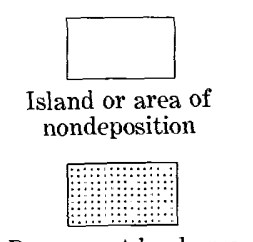

Permanent land area

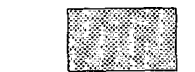

Nonmarine deposits
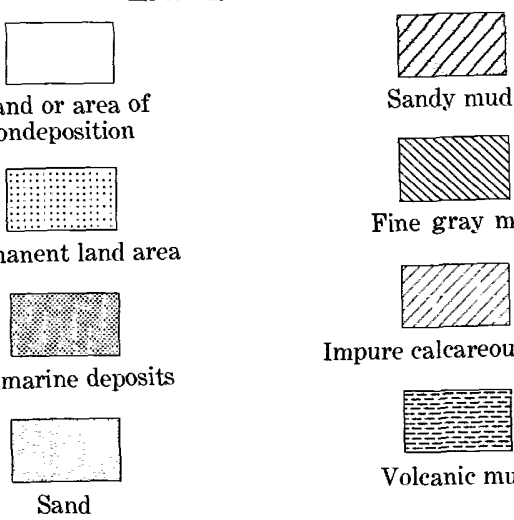

Sandy mud

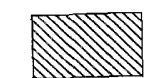

Fine gray mud
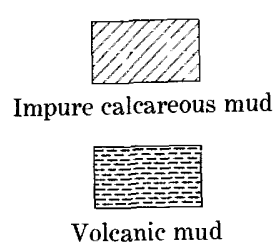

FIgURE 7.-Lithofacies and paleogeographic maps (from Reeside, 1957, figs. 19-21). A, Verendrye and Virgin Cræek time. $B$, Mobridge time. $C$, Fox Hills time. 
of $B$. grandis (Cobban, 1958, p. 114), is found in the Mobridge Member. Thus, the northward connection was probably closed prior to the deposition of this member. Closure probably occurred earlier in Canada, perhaps even before the Virgin Creek Member was deposited.

On a more local scale, Waagé $(1961$, p. 238$)$ reported that " $* * *$ the entire marine sequence of the Fox Hills and at least the upper 250 feet of underlying Pierre Shale pass westward within 50 miles (of the longitude of Dupree, S. Dak.), into a sandy sequency of predominantly brackish- and fresh-water beds." Thus, the shoreline was within 50 to 100 miles west of the area of investigation during the deposition of the uppermost part of the Pierre Shale.

The original extent of the Elk Butte, Mobridge, and Virgin Creek lithologies is unknown. Searight (1937, p. 35, pl. 7) described the Virgin Creek Member as cropping out along nearly the entire length of the Missouri River in South Dakota and stated that "It covers wide areas north, south and east of the Black Hills and has been observed beyond these South Daktota outcrops in southwestern North Dakota and in eastern Montana along the crest of the Cedar Creek anticline." Searight did not trace the Mobridge Member westward beyond South Dakota State Highway 63 (this paper, fig. 1) but reported (p. 44) that it $" * * *$ extends from a position near the North Dakota boundary to the southern boundary of South Dakota. *** The Elk Butte Member has been identified in outcrops extending between southeastern Gregory and southwestern Charles Mix Counties [S. Dak.] on the south, to northeastern Corson County [S. Dak.] on the north" (Searight, 1937, p. 50). According to Tourtelot $(1962$, p. 8$)$, these members are presently recognizable "for some distance along the valleys of the streams entering the Missouri River from the west."

\section{FORAMINIFERAL BIOFACIES}

The foraminiferal faunas of the upper part of the Pierre Shale and lower part of the Fox Hill Sandstone are variable. They change in specific, generic, and familial composition and in the number of families, genera, and species from place to place through the stratigraphic column; they define several assemblages or biofacies that probably reflect local changes in the benthic environment. These biofacies are not associated with obvious lithologic facies.

Three foraminiferal biofacies were recognized in the area investigated. These were the lower arenaceous (the term arenaceous being used to include all noncalcareous Foraminifera), upper arenaceous, and calcareous biofacies.
LOWER ARENACEOUS BIOFACIES

This biofacies has been recognized in two sections (fig. 4, sections 1 and 3) in the Moreau River stratigraphic sequence. It characteristically consists of four to 10 species, several of which may be represented by numerous specimens. The fauna is composed of at least 50 percent arenaceous species but, as a rule, also contains fairly abundant specimens of a few calcareous benthonic species and scarce specimens of one or two planktonic species. The most commonly occurring species in this facies are Bathysiphon brosgei?, Ammodiscus cretacer's, Haplophragmoides rota, Gaudryina bentonensis, Bulimina kickapooensis, and Cibicides harperi.

The lower arenaceous biofacies is found in the lowor 45 to 50 feet of the Virgin Creek Member. The top is not a clearly demarcated boundary between two easily distinguishable faunas but rather the level at which a marked increase in the number of foraminiferal speciss begins. This increase in species is dependent, for the most part, on a marked increase in the number of cr.lcareous benthonic species, especially species of the Lagenidae, Buliminidae, and Rotaliidae. There is also a large relative increase in the number of arenaceous species from four or five to eight or nine, but this is only a small percentage of the total increase in number of species.

Concomitant mineralogic and lithologic featuras help to characterize the lower arenaceous biofacies. Throughout the entire stratigraphic interval in whinh this biofacies exists there is evidence of the presence of free silica in the form of usually very abundant radiolarian tests and siliceous fillings of Foraminifera. Every specimen of calcareous Foraminifera seen from $t$ ) is biofacies was filled with silica, but arenaceous spe?imens were usually not filled. Lithologically this stratigraphic interval, which includes all the lower part of the Virgin Creek Member of Searight (1937) and part of the upper part of the Virgin Creek Member, is characterized by the presence of numerous thin bentonite layers, especially in the lower part, and by the noncalcareous and relatively erosion-resistant nature of the rock.

The species below occur in the lower, but not the upper, arenaceous biofacies; only those species marked by an asterisk occurred in more than one sample:

*Gaudryina bentonensis

G. watersi

*Silicosigmoilina futabaensis

Robulus muensteri

Dentalina legumen

Nodosaria proboscidea

Palmula cf. P. rugosa

Lagena apiculata 
Heterohelix globulosa

* Gyroidina girardana.

* "Discorbis" quadrilobus

Nuttallinella? disca

Hoeglundina supracretacea.

Rugoglobigerina cf. R. rugosa

*Cibicides harperi

UPPER ARENACEOUS BIOFACIES

The upper arenaceous biofacies occurs throughout much of the Elk Butte Member and is also found in the lower part of the Fox Hills Sandstone. The lower limit of this biofacies in the Moreau River stratigraphic section was found only in section 27A (fig. 4) where there is a transition from a predominantly calcareous fauna to an overlying predominantly arenaceous fauna through about 15 feet of section. The base of the biofacies was arbitrarily placed 36 feet below the base of the Fox Hills Sandstone, in about the middle of the transition interval. In section 31 (fig. 4) the lowest sample examined was about 56 feet below the base of the Fox Hills, but no transition interval was found, the arenaceous species being dominant from the base to the top of the section.

The contact between the calcareous biofacies and the upper arenaceous biofacies in the Grand River stratigraphic sequence occupies a transition interval of about 10 feet. It is present in two of the sections for which faunal data are available (fig. 5, sections 49 and 54). In both sections the boundary was arbitrarily placed in about the middle of the transition interval, about 72 feet above the upper key bentonite in section 54 and about 60 feet above the upper key bentonite in section 49.

In the Moreau River stratigraphic sequence the upper key bentonite is about 130 feet below the base of the Fox Hills Sandstone. The top 36 feet or so of this interval is occupied by the upper arenaceous biofacies. In the Grand River stratigraphic sequence the thickness from the upper key bentonite to the base of the Fox Hills Sandstone is approximately 200 feet, the upper 130 to 140 feet of which is the upper arenaceous biofacies. The thicknesses of all the intervals cited here are approximations because of the transitional nature of the lower boundary of the upper arenaceous biofacies and because the thicknesses given for some stratigraphic intervals are averages. The upper arenaceous biofacies is present throughout the part of the Fox Hills Sandstone studied in the outcrop areas of the Grand and Moreau River.

The upper arenaceous biofacies is characterized by Haplophragmoides rota (the most abundant and most consistently present species), H. bonanzaensis, Bathysiphon brosgei?, Ammodisous cretaceous, and Verneuiti- noides cf. $V$. perplexus. In addition, Reophax sp. and Spiroplectammina mordenensis are present in some samples from the Grand River stratigraphic sequence. Several calcareous benthonic species of Foraminifera occur in various samples, but the most frequently present and abundant is Planulina kansasensis. Te species below occur in the upper, but not the lower, arenaceous biofacies; only those species marked by an asterisk occurred in more than one sample:

*Reophax, sp., *Verneuilinoides cf. $V$. perplexus, *Quinqueloculina sp., *Trochammina globosa, Oolina obeliscata, Bulimina prolixa, *Neobulimina navarroana, *Planulina kansasensis, Cibicides subcarinatus, Incertae sedis sp.

The stratigraphic interval containing the upper arenaceous biofacies is usually noncalcareous, easily eroded gray shale or claystone containing a few thin bentonite beds, numerous concretion horizons and only a few species and scarce specimens of Radiolaria. Throughout most of this interval, the average amount of residue retained on a 200-mesh sieve per unit weight of unwashed rock was the same as for the underlying rocks, but within about 50 feet of the top of the Pierre Shale the amount of residue increased. Generally associated with this increase were increases in th? precentages of muscovite and fossil plant fibers in the residues.

\section{CaLCareous bIOFACIES}

The calcareous biofacies lies between, and is gradational with, the upper and lower arenaceous biofacies (fig. 6). It is characterized by the presence, in most samples, of a rather large number (eight to 36) of calcareous, mostly benthonic, species of Foramir ifera. The number of arenaceous species in the samples is slightly larger than the number in either of the arens coous biofacies.

The lower boundary of this biofacies is prasent only in section 3 (fig. 4) in the Moreau River sections, where it lies about 155 feet below the base of the lower key bentonite. The lower boundary was not seen in any of the Grand River sections, none of which extends any lower than 48 feet below the lower key bentonite. The upper boundary is present only at locality $27 \mathrm{~A}$ (fig. 4) in the Moreau sections, where it occurs about 36 feet below the base of the Fox Hills Sandstone. In the Grand River sections the upper boundary is present at localities 49 and 54 (fig. 5) where it occur: approximately 60 to 75 feet above the upper key bentonite.

The generic and specific compositions of faunas within the stratigraphic interval containing the calcareous biofacies vary from sample to sample, but the number of species and genera decrease as a goneral rule from the base to the top. On the familial level, the Lage- 
nidae are more abundant than any other family in the number of species and genera, though not in the number of specimens, throughout much of the biofacies. Lagenid species are most common in the lower 100 to 150 feet of the biofacies and gradually decrease in number up the section. Other families of importance are the Anomalinidae, represented in the lower part of the biofacies primarily by $C$ ibicides harperi and $C$. subcarinatus and in the upper part by Planulina kansasensis; the Chilostomellidae, represented by Pullenia dakotensis; the Epistominidae, represented by Nuttallinella? disca; the Rotaliidae, represented chiefly by Gyroidina depressa; the Buliminidae, represented chiefly by Bulimina kickapooensis and Loxostoma plaita; the Heterohelicidae, represented chiefly by Heterohelix globulosa; and the Textulariidae, represented by Spiroplectammina Taevis cretosa. The family Ceratobuliminidae, represented by Hoeglundina supracretacea, is common in samples from the Morean River stratigraphic sequence but rare in the Grand River sequence. The species restricted to or most common in the lower part of the calcareous biofacies and generally represented by large numbers of specimens are Cibicides harperi, C. subcarinatus, Gyroidina girardana, G. globosa, and Spiroplectammina laevis cretosa. Their counterparts in the upper part of the biofacies are Planulina kansasensis, Bulimina kicka pooensis, Loxostoma plaita, and Neobulimina navarroana. Samples taken at random were accurately placed stratigraphically by a comparison of the contained species with the ranges of these diagnostic species. The accuracy of this stratigraphic placement is directly dependent upon the number of diagnostic species in the sample. Despite the predominance of Lagenidae in the calcareous biofacies, no lagenid species are considered diagnostic because specimens of the various lagenids are scarce and because there is typically little continuity to the stratigraphic distribution of the species within the biofacies.

The stratigraphic interval occupied by the calcareous biofacies is typically a gray, slightly to very calcareous, easily eroded shale or claystone which includes both the upper and lower key bentonites, a few thinner and less persistent bentonites, and a large number of concretion horizons.

\section{STRATIGRAPHIC AND AREAL DISTRIBUTION}

The three biofacies characterize the vertical forminiferal succession in the upper part of the Pierre Shale. The boundaries between the biofacies are gradational. Strata containing the lower arenaceous biofacies were not found in any sections along the Grand River, but the upper two biofacies were found in sections from both the Grand and Moreau Rivers. The calcareous and the upper arenaceous biofacies from the Grand River sections were similar in faunal composition to the same respective biofacies in the Moreau River sections. It should be possible to find these three biofacies, in the order in which they occur in this area, through different timespans within the eastern part of the Pierre and Fox Hills outcrop area, though it is likely that there will be differences in specific composition and in dominant species.

\section{FAUNAL DETAILS AND ORIGIN}

As so far considered, the biofacies are no more than empirically defined pieces of a larger faunal complex. In order to improve understanding of them, it is necessary to consider some faunal details and various alternative explanations for their existence.

One of the more important questions which can be asked with regard to these foraminiferal faunas, anc one of the more difficult to answer, is to what degree they represent the remains of actual living communities. Possibilities which must be taken into account include the addition of specimens of "foreign" species by currents, the selective removal of parts of the original communities by diagenetic or postdiagenetic destruction, and the mixing of a number of communities during sampling. It is more likely that longer ranging specie: have been secondarily introduced because they persist. while the general compositions of the faunas change, presumably because of ecologic changes. But specimen? of these long-ranging species are generally as well preserved as the associated specimens, and they are present in large numbers. Both factors seem to contradic ${ }^{+}$ transportation. The presence of long-ranging species in the upper part of the Pierre and lower part of the Fox Hills, for lack of contrary evidence, implies that thes? species were able to survive under a variety of ecologi? conditions, some of which could not be tolerated by other species. The problem of the selective diagenetis removal of specimens is real, as indicated by the presence of pyritic internal molds of some specimens in a number of samples. The degree to which this biases interpretation of the original faunal composition cannct, be determined. In samples containing abundant wellpreserved calcareous specimens, I have assumed destruction to be relatively unimportant. The usual presence of one or more calcareous species, represented by aburdant specimens in the upper arenaceous biofacies and the scarcity of internal molds indicates that the procers of selective destruction of calcareous specimens was not the cause of the faunal aspect of this biofacies. However, there is evidence from some samples that selective destruction was operative, just as it was in some samples from the calcareous biofacies. Calcareous specimens in 
the lower arenaceous biofacies are always filled with silica, and many specimens have had their original calcareous tests dissolved away. Selective destruction was certainly operative here but apparently was largely offset by the production of internal molds of silica in many of the calcareous specimens originally present. The usual presence of fairly large numbers of internal molds for most of the calcareous species makes it unlikely that there originally was a significantly larger representation of calcareous species than has been discovered.

The three biofacies encompass variations that occur from sample to sample and between small groups of samples. All species are only sporadically present within the limits of their total vertical ranges, a fact indicating that conditions from time to time and from place to place were unfavorable for either their existence or preservation. Analysis of all the individual variations is not attempted, but several more faunal changes within the calcareous biofacies are deserving of comment.

A dramatic faunal change occurs in the vicinity of the lower key bentonite in the Grand River valley. Sample 10 of section 37 (fig. 5), inmediately below the lower key bentonite, contains 25 species, four of which are arenaceous, whereas in sample 12, about 8 feet above this bentonite, there are only five species, two of which are arenaceous. Another section which shows the same set of conditions is section 42 (fig. 5) where 23 species, two of which are arenaceous, are present immediately below the bentonite, and six species, all arenaceous, are present in the next sample 6 feet above it. In section 44 (fig. 5), sample 1A, immediately below this bentonite, contains nine species, two of which are arenaceous; sample 1 , immediately above the bentonite, contains only one species, and it is arenaceous. Higher in section 44 some of the calcareous species present below the bentonite reappear, but the fauna never regains the diversity present below the bentonite. The group of sections in which this marked faunal change occurs is in a northsouth strip of territory in the vicinity of the town of Wakpala, S. Dak. (fig. 1). One other section, section 45 (fig. 5), which lies about 5 miles west of Wakpala begins just above the level of the lower key bentonite yet has a diverse fauna of 27 species, three of which are arenaceous, at its base. No such marked faunal change occurs in the vicinity of the lower key bentonite in any of the Moreau River sections. Thus the cause or causes of this change operated over a restricted area. What relationship the bentonite had to this change is not clear. It is not likely that the effects of the fall of this single layer of ash should have been so drastic or so permanent, especially in view of the fact that considerably thicker bentonites elsewhere have not appeared to affect the fauna noticeably. In fact, there may have been no effect on the living fauna at all but simply accelerated destruction of the tests in the sediment. In the shale above that bentonite, the presence of pyritic internal molds of several calcareous species of Foraminifera indicates that a larger fauna may have been living on the site than has been preserved.

Several sections have hard light-gray to buff highly calcareous shale beds a foot to several feet thick. Several of these beds were examined for micrcfossils and yielded abundant planktonic Foraminifera. In one bed, the coarse fraction was composed almost entiroly of specimens of Heterohelix globulosa and Biglobigerinella biforaminata, the latter predominant. It is impossible to say whether the entire calcareous content ras derived from the tests of these planktonic animals. Nevertheless, their tremendous abundance and their presence in much less spectacular numbers elsewhere indicate that conditions favoring their proliferation or preserration were only rarely achieved; lack of lateral persistence of highly calcareous planktonic-rich layers suggests that these favorable conditions were extremely local.

The siliceous nature of the microfauna in the lower 50 feet of the Virgin Creek Member in sections 1 and 3 (fig. 4) and in the shale above the upper key bentonite in sections 44 and 49 (fig. 5) has already been mentioned. In sections 1 and 3, radiolarians are presert, in abundance, and the Foraminifera are few and silicified. In section 44, radiolarians are present, and the silicified foraminiferal fauna is composed of few specim?ns and species. In section 49 , the foraminiferal fauna is represented by a small number of silicified specimens belonging to a few species, but there are no radiolarians. The presence of radiolarians must have been favored by conditions which were only occasionally in effect because they are absent in most of the upper part of the Pierre Shale. The release of silica into the sea water as a result of the alteration of volcanic ash, now preserved as bentonite in the lower part of the Virgin Creek Member, may have provided either directly or indirectly for the proliferation of these organisms and for the small number of Foraminifera. Alternatively, the number and kinds of Foraminifera may have been origir ally greater, but adverse chemical conditions within the sediment may have destroyed most specimens. If the release of silica were responsible for the silicification of the Foraminifera in sections 44 and 49 and for the presence of the radiolarians in section 44 , then it can be assumed that the volcanic ash was disseminated through the shale. Discrete bentonite beds like those in the lower part of the Virgin Creek Member are not present in the intervals that contain the silicified fossils in these sections. 


\section{ENVIRONMENTAL INTERPRETATIONS}

The environmental interpretations of the upper part of the Pierre Shale and lower part of the Fox Hills Sandstone are by no means complete characterizations of the original living environments. Rather, they are the result of inference and analogy based on the biologic and lithologic evidence found in these deposits and on pertinent evidence from other areas. The biologic data include information on the composition, abundance, preservation, and the vertical and, to a lesser extent, horizontal distribution of the foraminiferal faunas. The lithologic data from the upper part of the Pierre include information on the relative abundance of calcium carbonate and silt-sand, the composition of the coarse fraction of the shale, and the vertical and, to a lesser extent, horizontal nature of the stratigraphic sequence.

\section{BIOLOGIC INFORMATION}

Because Foraminifera are abundant fossils commonly found in the strata invesigated, they are well suited for use in interpreting paleoecology. Phleger (1960a, p. 102103), in his discussion of depth distribution of Recent Foraminifera, stated that the important ecologic factors may be one, all, or some of the following: temperature, salinity, food supply, water chemistry, hydrostatic pressure, turbidity, turbulence, substrate, currents, biologic competition, or disease. Consequently, the depth range of a species is an obtuse and imprecise expression of the limits of effectiveness of the numerous ecologic factors which actually determine the distribution of the species. However, because little information is available on the degree or manner in which many factors affect species of Foraminifera and because depth is an easily determinable factor, most foraminiferal ecologists have expressed the distribution of modern species in terms of depth.

The application of modern distributional information to fossil faunas is complicated by two factors: evolution and preservation. If the fossil fauna contains species present in modern oceans, it is customary to infer for the fossils an environment similar to that in which the modern representatives live. Only a few species from the upper part of the Pierre Shale have living representatives, so the ecologic conditions to which the majority of species were adapted cannot be inferred by reference to modern faunas. Thus, the present can be a key to the past only on the generic or familial level or by means of interpretations which do not depend upon genetic affiliations.

An examination of the data which Phleger (1960a, figs 14-36) presented on the depth distribution of modern species off the coasts of the United States and Mexico reveals that the depth distribution of most genera is considerable and leaves little doubt that presence or absense of individual genera does not give precise depth information. Other authors have considered the dominance of various genera and families at different depths; some of the information that they presented is considered later.

Problems of preservation must also be considered in interpreting fossil faunas. This subject was ably explored by Johnson (1960), who, by means of models, illustrated the many ways in which death assemblages may be altered or destroyed before they are available to the paleontologist for sampling. Alteration of the character of a foraminiferal faunal assemblage on the bottom or below the sediment surface would appear to be most readily accomplished on the basis of test composition. Parker and Athearn (1959) recorded dramatic evidence of preferential removal of calcareous tests within the upper 1 centimeter of sediment in the marshes of Poponesset Bay, Mass. They noted (1959, p. 338) that calcareous species are represented for the most part by living specimens: "Very few dead ones were observed. This leads to the inference that below the sediment surface, or perhaps even at the sedimentwater interface, the $\mathrm{pH}$ is sufficiently low to cause the dissolution of the tests. If this condition exists in the 'living environment' of the species they must have some mechanism to resist the acidity. Since this implies the expenditure of considerable energy on the part of the organism, it seems more probable that the increase in acidity occurs immediately below the sediment surface, probably due to decaying vegetation, and that it is here that the solution of tests occurs."

The presence of pyrite and unoxidized plant fragments in most samples from the upper part of the Pierre Shale and lower part of the Fox Hills Sandstone indicates that reducing conditions prevailed beneath if not above the sediment-water interface during deposition. Also, the presence of pyritic or siliceous internal molds of calcareous Foraminifera in a number of samples indicates that some process of removal of $\mathrm{CaCO}_{3}$ was operative. In discussing the changes produced in sediments as a result of the activities of micro-organisms, ZoBell (1942, p. 131) stated that "Depending upon the numbers and kinds of micro-organisms present, the substrate and environmental conditions, [bacteria] might increase the acidity or decrease it." And later, ZoBell (1946, p. 503) reported that "The $\mathrm{pH}$ of the bottom deposits ranges from 6.4 to 9.5 , most of them falling in the range of $\mathrm{pH} 7.5$ to 9.0 ," and "The $\mathrm{pH}$ of most sediments was found to increase with depth." Shepard and Moore (1955, fig. 44C) recorded changes in $\mathrm{pH}$ in several modern environments along the central Texas coast. They found that the $\mathrm{pH}$ of marine sediments is 
slightly higher than neutral at the surface and increases slightly with depth within several short cores.

In discussing the geochemistry of the Pierre Shale, Tourtelot (1962, p. 11) was more positive about the $\mathrm{pH}$ of sediments containing unoxidized organic matter. He stated that "Bacterial or chemical reduction of sulfate also promoted acidic as well as reducing conditions. Some calcium carbonate and other compounds were increasingly dissolved and were either cycled back to the overlying sea water or were segregated as diagenetic concretions in favorable microenvironments within the zone of diagenesis." Though this statement may be true in general and possibly explains the absence of calcareous Foraminifera in certain parts of the Pierre section, it cannot be rigorously applied to the calcareous biofacies of the upper part of the Pierre Shale. There, abundant calcareous tests have been preserved, an indication that this process, if it worked at all, did not go to completion, perhaps because of insufficient amounts of organic material.

Comparison of fossil and Recent foraminiferal faunas can be most precisely done on the species level, but because very few of the species found in this study persist to the Recent, it was necessary to utilize less precise measures. One such measure was the comparison of the distribution and abundance of fossil genera with the same genera in the Recent. Attempts to make this kind of comparison between the genera from the upper part of the Pierre Shale and lower part of the Fox Hills Sandstone and the same genera in the Gulf of Mexico, based on data given by Phleger $(1960 \mathrm{~b})$ and Lowman (1949), were not very successful. Several of the dominant benthonic genera and species (Bulimina kickapooensis, Pullenia dakotensis, Hoeglundina supracretacea, and Gyroidina depressa), remain dominant through nearly the entire thickness of rock examined, although most other species, including several particularly common ones (Cibicides harperi, C. subcarinatus, Loxostoma plaita, and Planulina kansasensis), are more confined in vertical range. This pattern and its poor comparability with the Recent Gulf patterns seem to have two possible explanations. First, the Cretaceous Foraminifera were adapted to conditions in an interior sea that may not have been analogous to conditions in the Gulf. Second, the ability of several species to persist through a considerable length of time and to remain dominant throughout suggests that life conditions were fairly uniform. Thus, the faunal changes might indicate smaller scale fluctuations in environment not comparable with Recent depth patterns.

Recent and fossil formaminiferal comparisons may also be made at the familial level. Comparability becomes better at this level because most Cretaceous fami- lies are still represented in Recent seas, but there is a concomitant loss of precision because of the large environmental ranges of most families. Although presence or absence of individual families is of practically no use in making paleoecologic interpretations, sorre information, even if only suggestive, may be obtained when the familial compositions of many different samples are considered together. In the following family-lerel analysis of the upper Pierre-lower Fox Hills foraminiferal faunas, the family designations are chiefly those of Cushman (1946).

The Foraminifera in the upper part of the Pierre Shale and lower part of the Fox Hills sandstone have been placed in 20 foraminiferal families. $T$. e presence of members of these families varies, of course, from sample to sample. It is possible to analyze this variation in several ways, the most simple of which is based on specimen counts for each species in each sample. Because abundances were estimated rather than counted in this study, these estimated abundances were not used in the analyses, although they were included under the species descriptions. Beginning with the data on presence or absence of species in samples, the first step in analyzing the available data was the plotting of the number of species present in each sample against the total number of samples to determine the more typical faunal sizes. This plot, representing 192 samples (fig. 8), shows that 87 samples contain zero to five species, 50 samples contain six to 10 species, and 55 samples contain more than 10 species. Another step in drawing togethor information on the distribution of families in these faunas was the plotting of familial composition of each sample examined on $360^{\circ}$ pie diagrams. It is not possible to include all these diagrams here, so I have separated the faunas into three broad divisions correspor ding to the foraminiferal biofacies discussed earlier. The 50 fossiliferous samples examined from the upper arenaceous biofacies, none of which contains more than 10 species, are represented in figure 9 . The 66 fossiliferous samples of 10 or fewer species examined from the calcareous biofacies are represented in figure 10 . The 53 fossiliferous samples from this biofacies of more than 10 species are represented in figure 11, and the 10 fossiliferous samples from the lower arenaceous biofacies, including one of more than 10 species, are represented in figure 12. Each of these figures is a plot of the number of samples in which representatives of the various families occur, and the number of samples in which any family is dominant is indicated by patterns. Dominance of a family is in terms of number of species, not number of snecimens.

Examination of the family occurrences in the upper arenaceous biofacies (fig. 9) reveals that tha Lituolidae is the family most commonly represented and most 


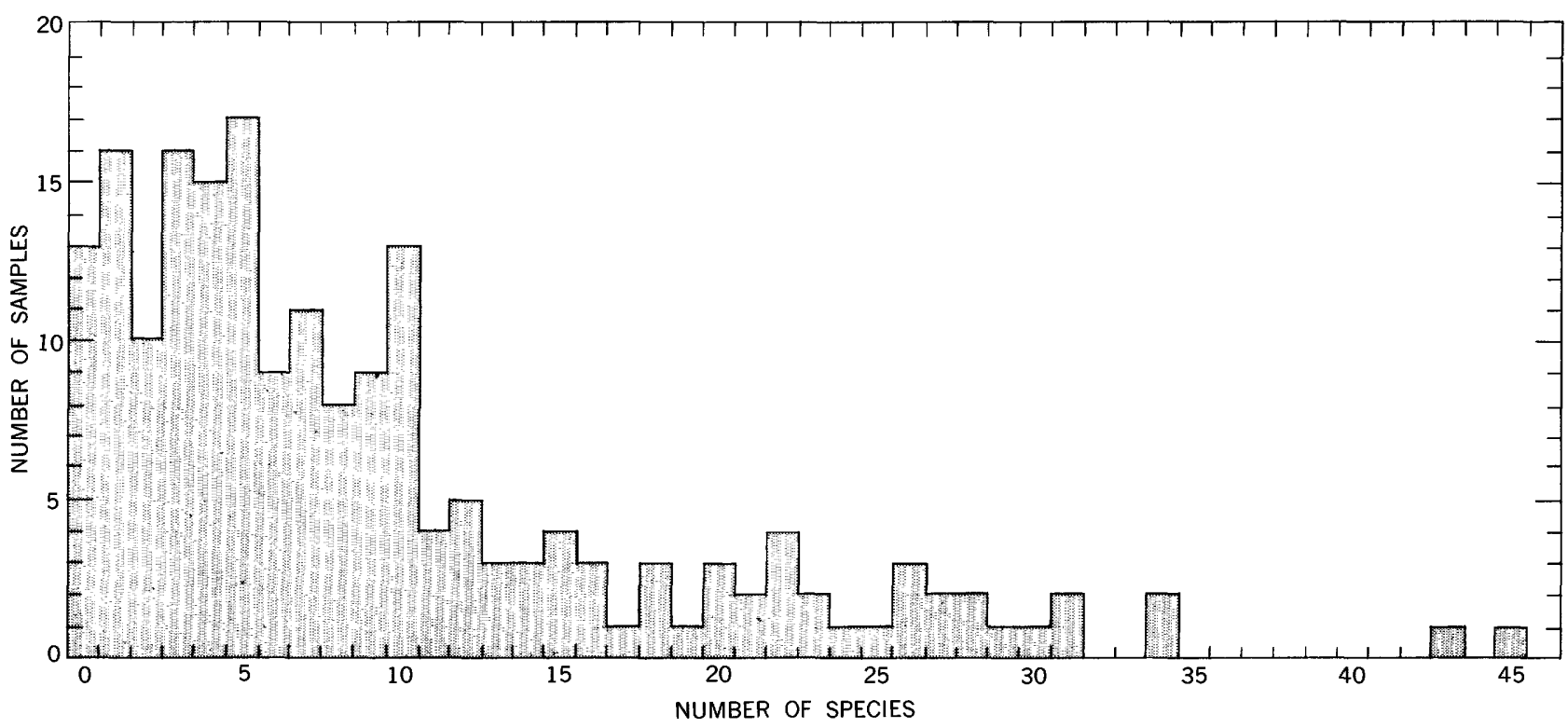

FIGURE 8.-Number of species in 192 samples from the upper part of the Pierre Shale and lower part of the Fox Hills Sandstone.

commonly dominant. The arenaceous nature of this biofacies is reflected in the larger number of arenaceous families represented and their greater frequency of represenation. Among the calcareous families, the Anomalinidae and Buliminidae are the best represented and are occasionally dominant.

In the calcareous biofacies, those samples containing 10 or fewer species (fig. 10) almost always contain species of Buliminidae and are most often dominated by Buliminidae. Other prominent and occasionally dominant calcareous families in these faunas are the Anomalinidae, Rotaliidae, Chilostomellidae, and planktonic Heterohelicidae. The Lituolidae is still the most often present and most often dominant of the arenaceous families, followed closely by the Textulariidae. In samples from the calcareous biofacies that contain 11 or more species (fig. 11), the average faunal character is markedly changed. The Lagenidae, which is not a dominant family in smaller faunas from this facies, is the most often dominant family, followed closely by the Buliminidae. One or the other of these two families is dominant in almost every sample, although the Rotaliidae, Anomalinidae, and planktonic Heterohelicidae are also present in almost all samples. The large increase in frequency of occurrence of calcareous benthonic and planktonic species and the presence of more families overshadow a smaller increase in the frequency of occurrence of arenaceous species and a shift in their pattern of familial representation. In these samples, the Lituolidae are less commonly present than are the Am- modiscidae, Textulariidae, and Verneuilinidae. The lasł. is the most commonly present arenaceous family.

The familial pattern for the 10 samples representing the lower arenaceous biofacies (fig. 12) is basically like that from the upper arenaceous biofacies. The arenaceous families are more often represented than are th? calcareous benthonic or planktonic families. The arenaceous families more often present are the Ammodiscidae, Lituolidae, and Verneuilinidae. The Buliminidaa and Anomalinidae are again the calcareous families more often represented, as they were in the upper arenaceous biofacies. Indication of dominance is lacking in figure 12 because in most samples more than thre? families were equally dominant.

Figures 9-12 show some of the more obvious faung, patterns present at the familial level in the foraminiferal faunas examined. To a certain degree they aid in quantifying the foraminiferal biofacies. Because they are useful for comparison between Recent and ancient patterns of family distribution, they facilitate interpre.tation of environments. Finally, they are a means of comparison between the family-level characteristics of the various biofacies. Before examining analogous Recent and ancient patterns or drawing comparative parallels between facies, it must be emphasized that because these patterns represent rather crude generalizations the results must be considered only suggestive.

The general similarity of pattern between the lower. and upper arenaceous biofacies suggests similar ecologic controls. It is not known whether these controls wero 


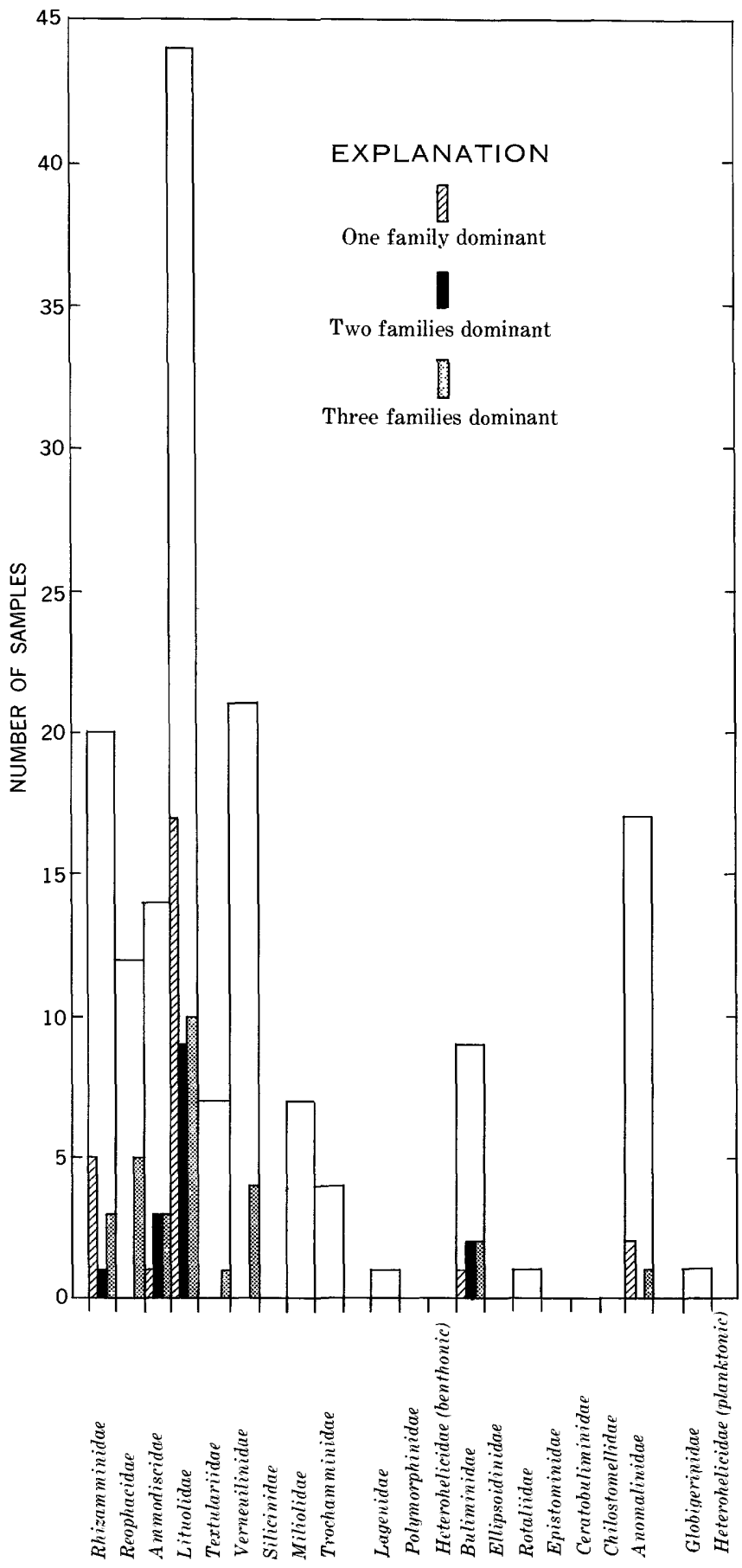

Frgure 9.-Distribution of families in 50 fossiliferous samples from the upper arenaceous biofacies. Families are plotted against the number of samples in which they occur. Height of patterned area indicates the number of samples in which one to three families are dominant. That family containing the most species in a given sample is considered dominant. For samples with two or three families equally dominant, each family is considered one-half or one-third dominant. Where four or more families contain the same number of species, no family is considered dominant.

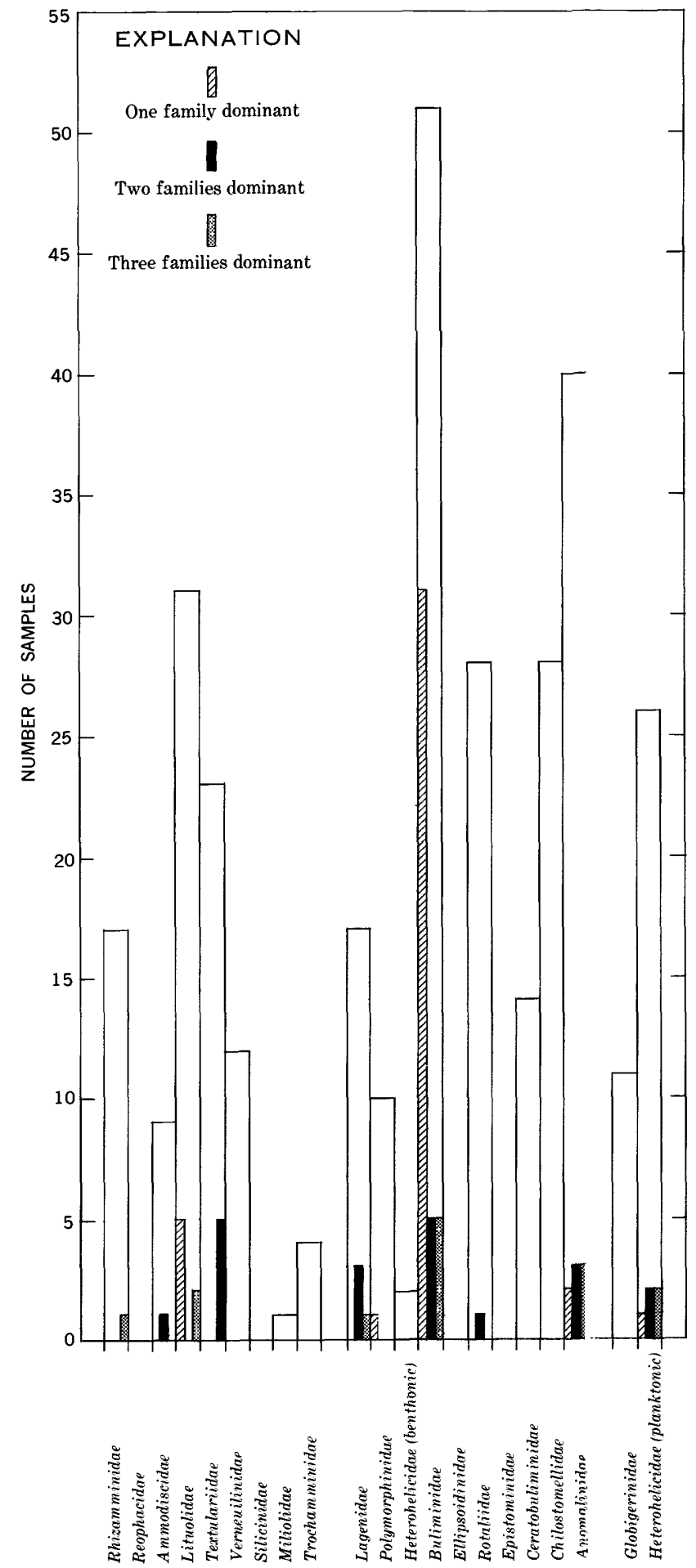

Frgure 10.-Distribution of families in 66 fossilifero's samples containing one to 10 species from the calcareous biofacies. See figure 9 for explanation. 


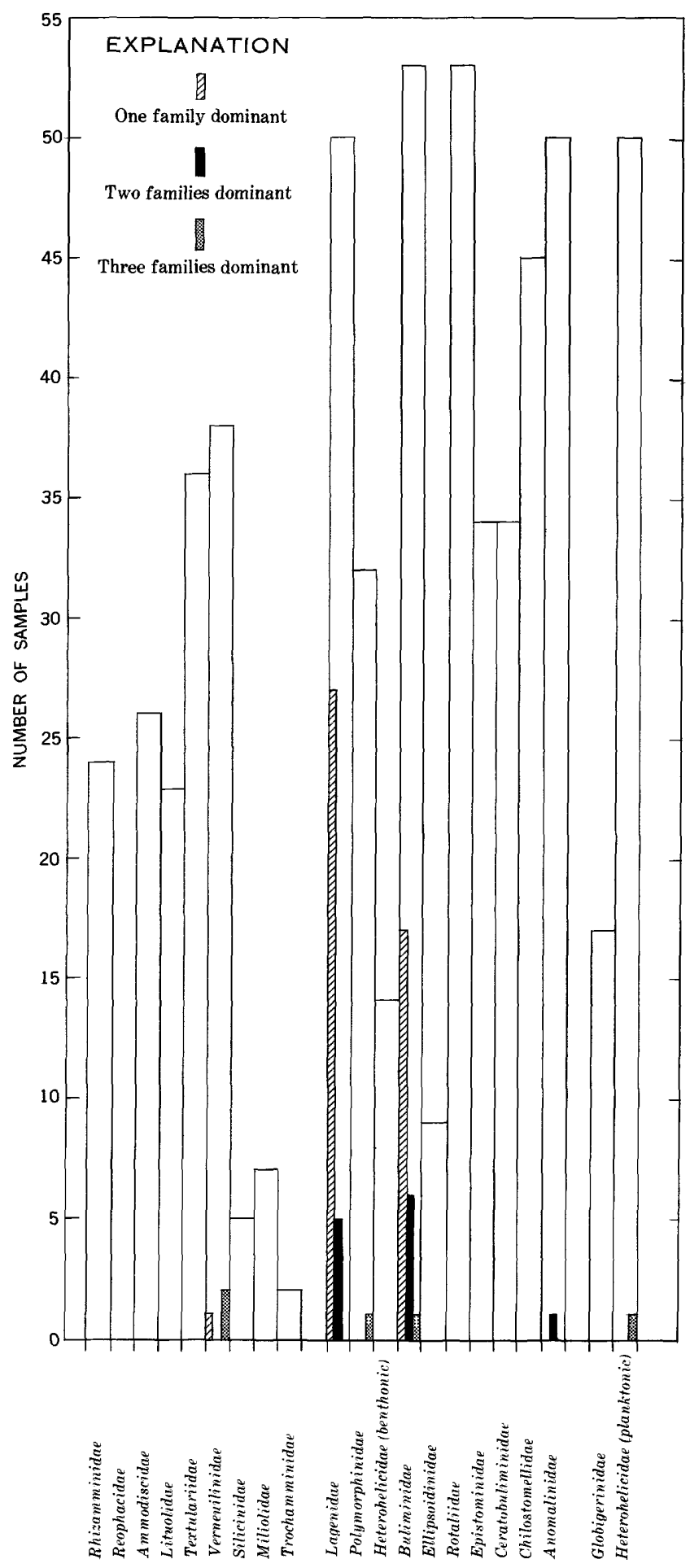

FIGURE 11.-Distribution of families in 53 samples containing 11 or more species from the calcareous biofacies. See figure 9 for explanation.

related to depth similarities or to depth-independent parameters. The markedly different character of the calcareous biofacies pattern suggests that ecologic con-

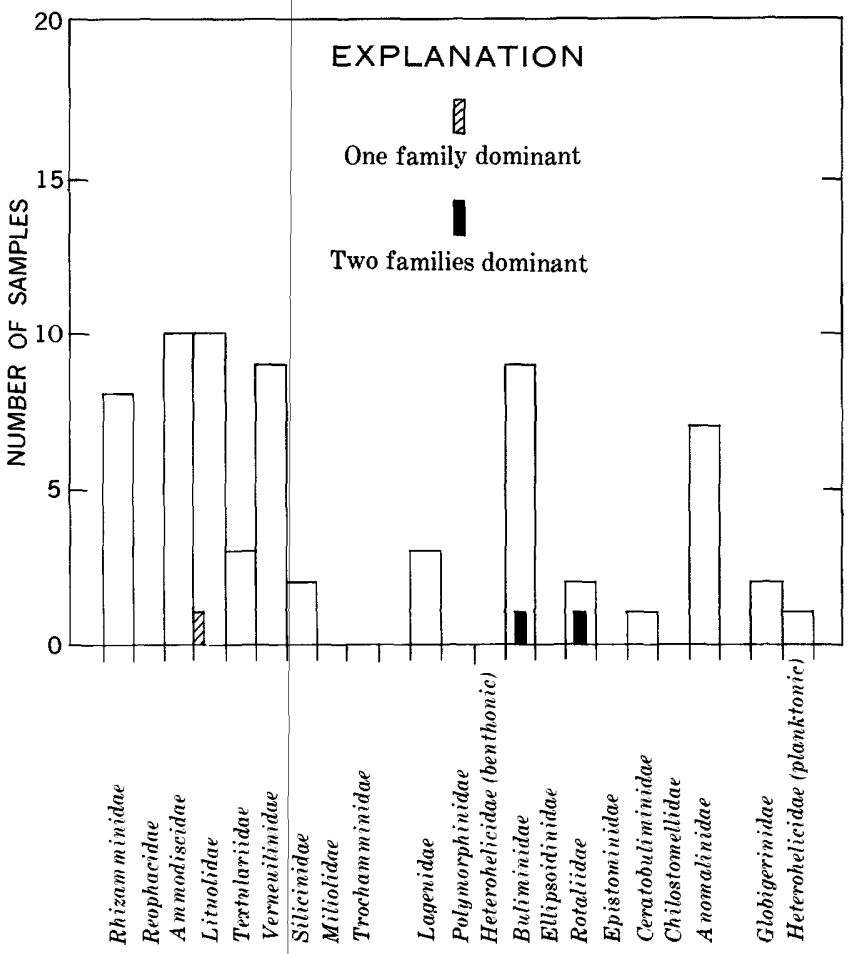

Figure 12.-Distribution of families in 10 fossiliferous samples from the lower arenaceous biofacies. See figure 9 for explanation.

ditions were in some way different for these faunas. The transition from the lower arenaceous biofacies to the lower part of the calcareous biofacies (fig. 13) is more abrupt than the transition between the calcareous and upper arenaceous biofacies (figs. 13, 14). If the rate of sedimentation was uniform, this asymmetry reflects a more abrupt change of ecologic conditions at the lower boundary of the calcareous biofacies than occurred at the upper boundary, possibly because of a rapid transgression and slow regression similar to those inferred by Weimer (1960) for the central and western parts of the Cretaceous sea in the western interior. Alternatively, the asymmetry may be a result of slower sedimentation at the lower boundary and may not reflect a more rapid change in ecologic conditions.

According to Phleger (1960a, p. 261), the use of families in foraminiferal paleoecology is of questionable value. Nevertheless, some of the information on Recent and ancient family-level distributions can be related to the upper part of the Pierre to lower part of the Fox Hills distributions. Lowman (1949, table 2, p. 1956) discussed the Recent depth distribution of Foraminifera in three traverses into the Gulf of Mexico and summarized some of his data, in part at the family level. If the genera and families represented in the upper part of the Pierre Shale are related to Lowman's generalized Gulf Coast sequence, both of the arenaceous biofacies 323-073 0-69-3 


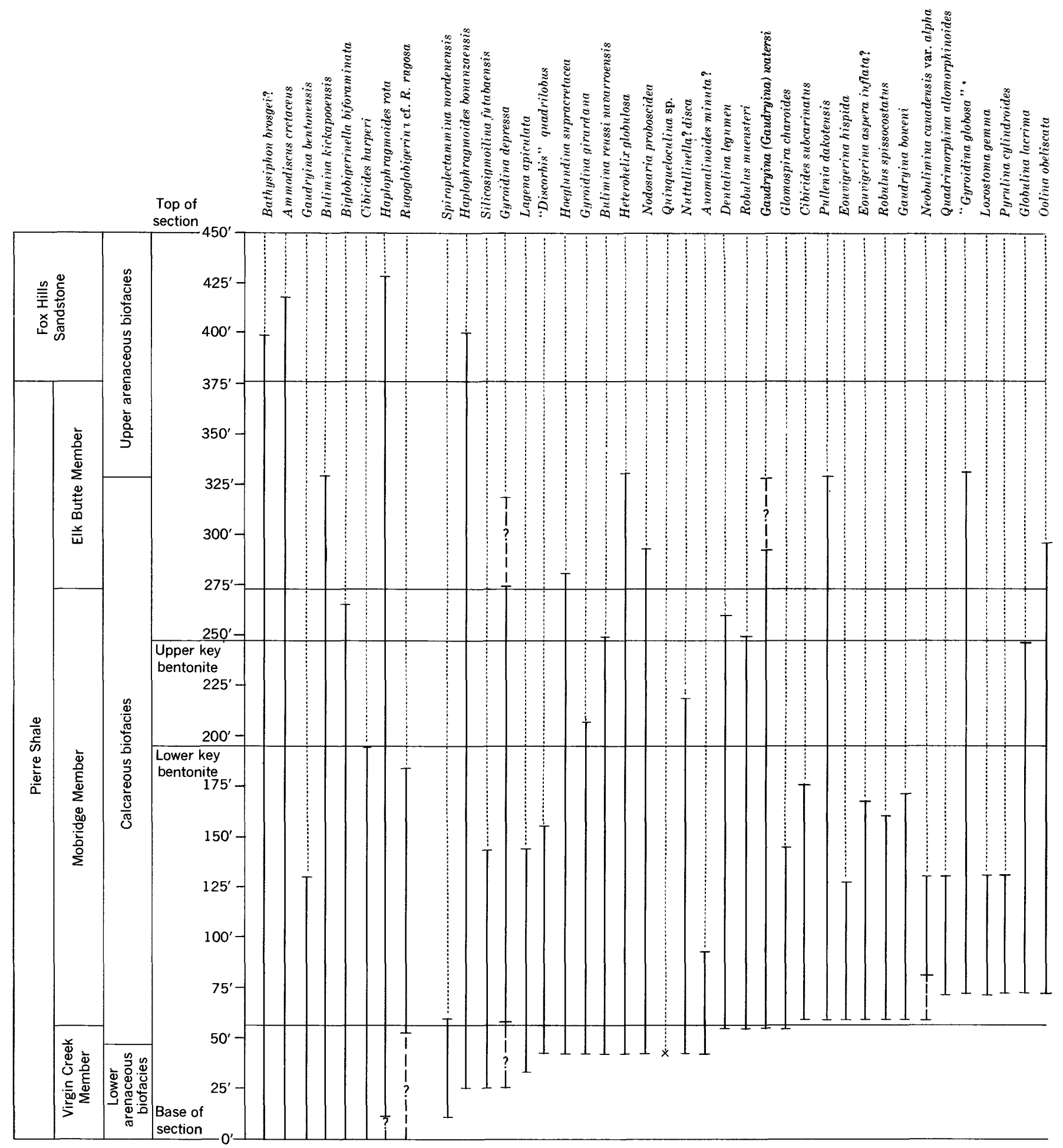




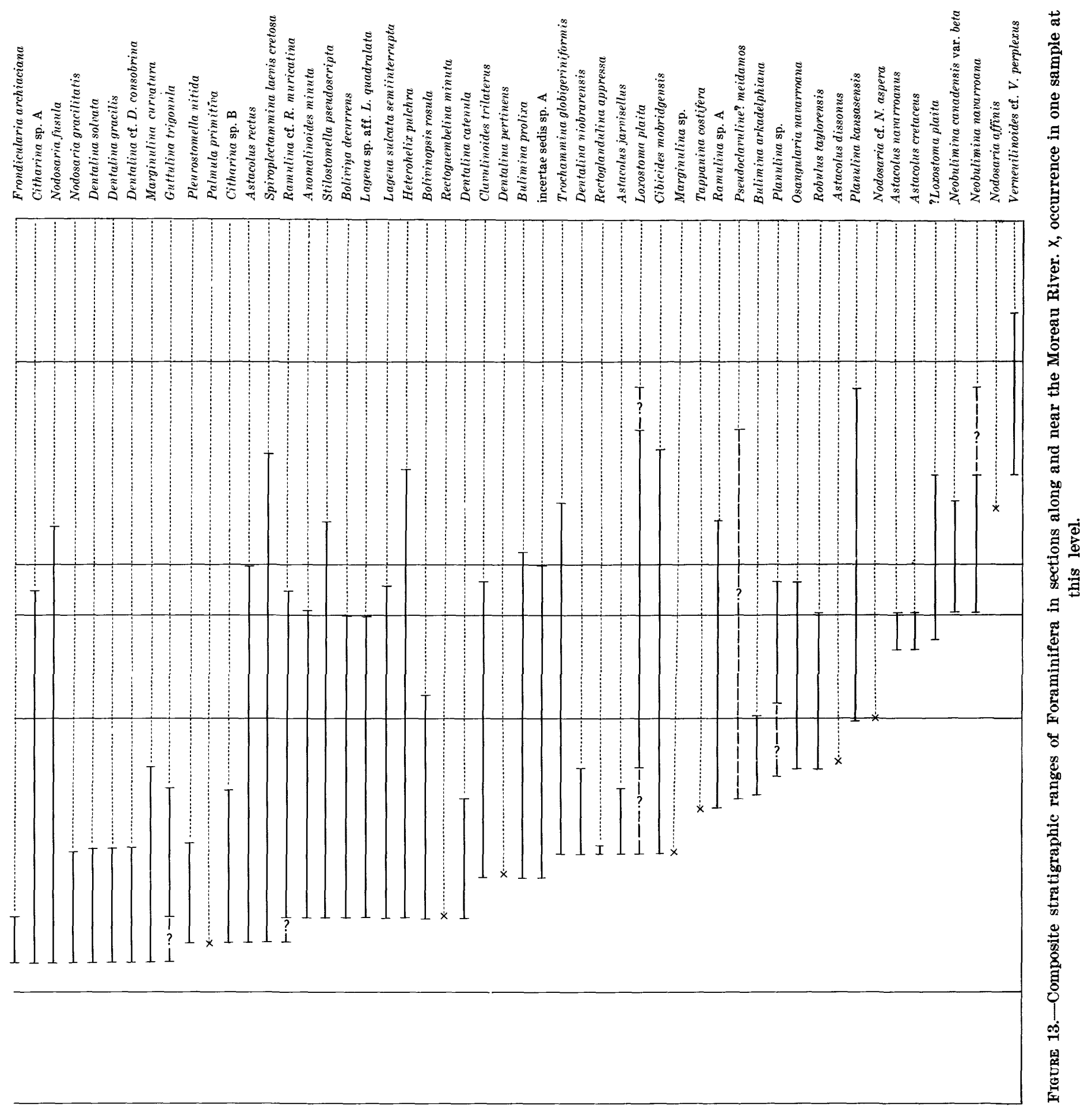




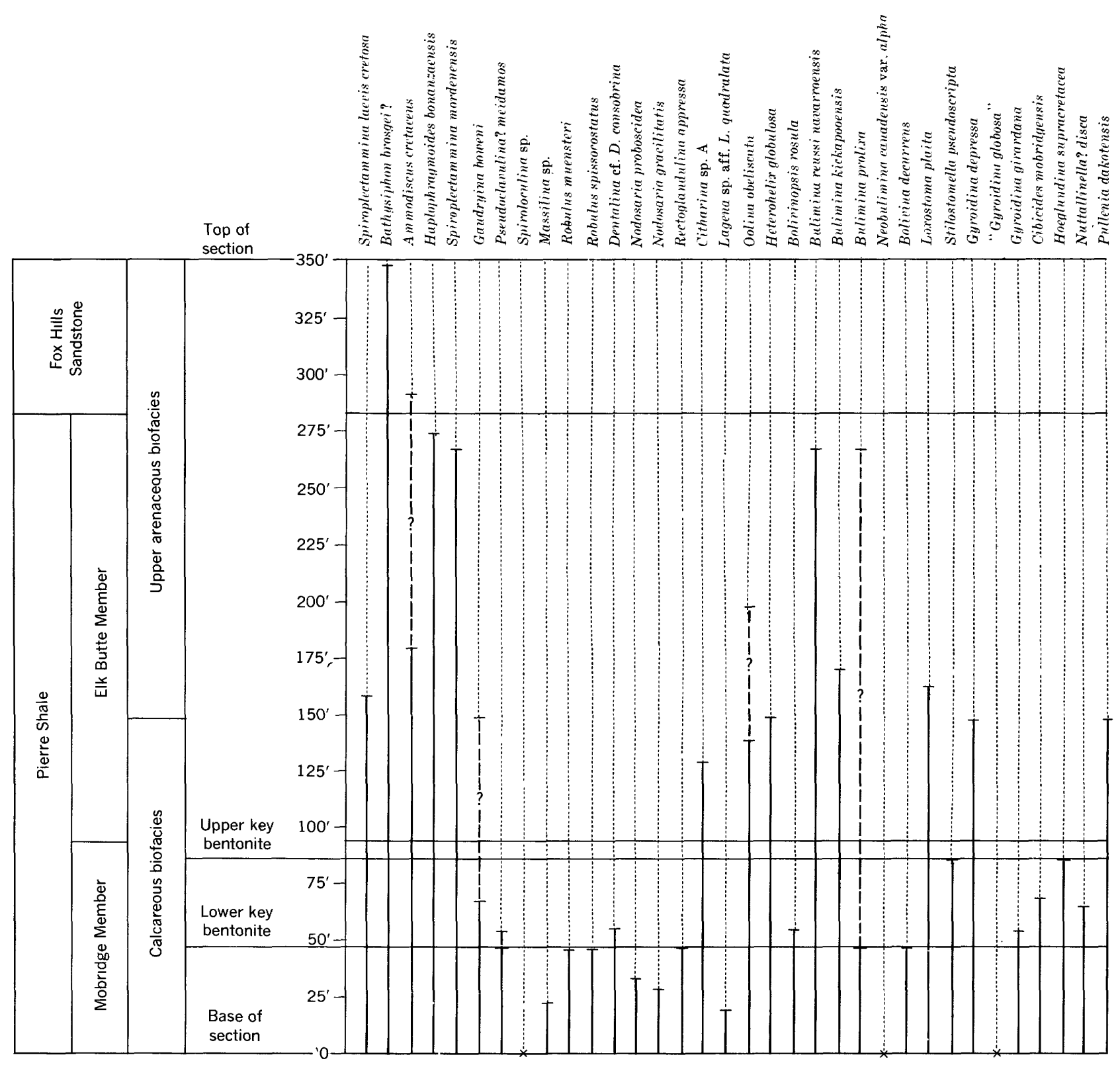




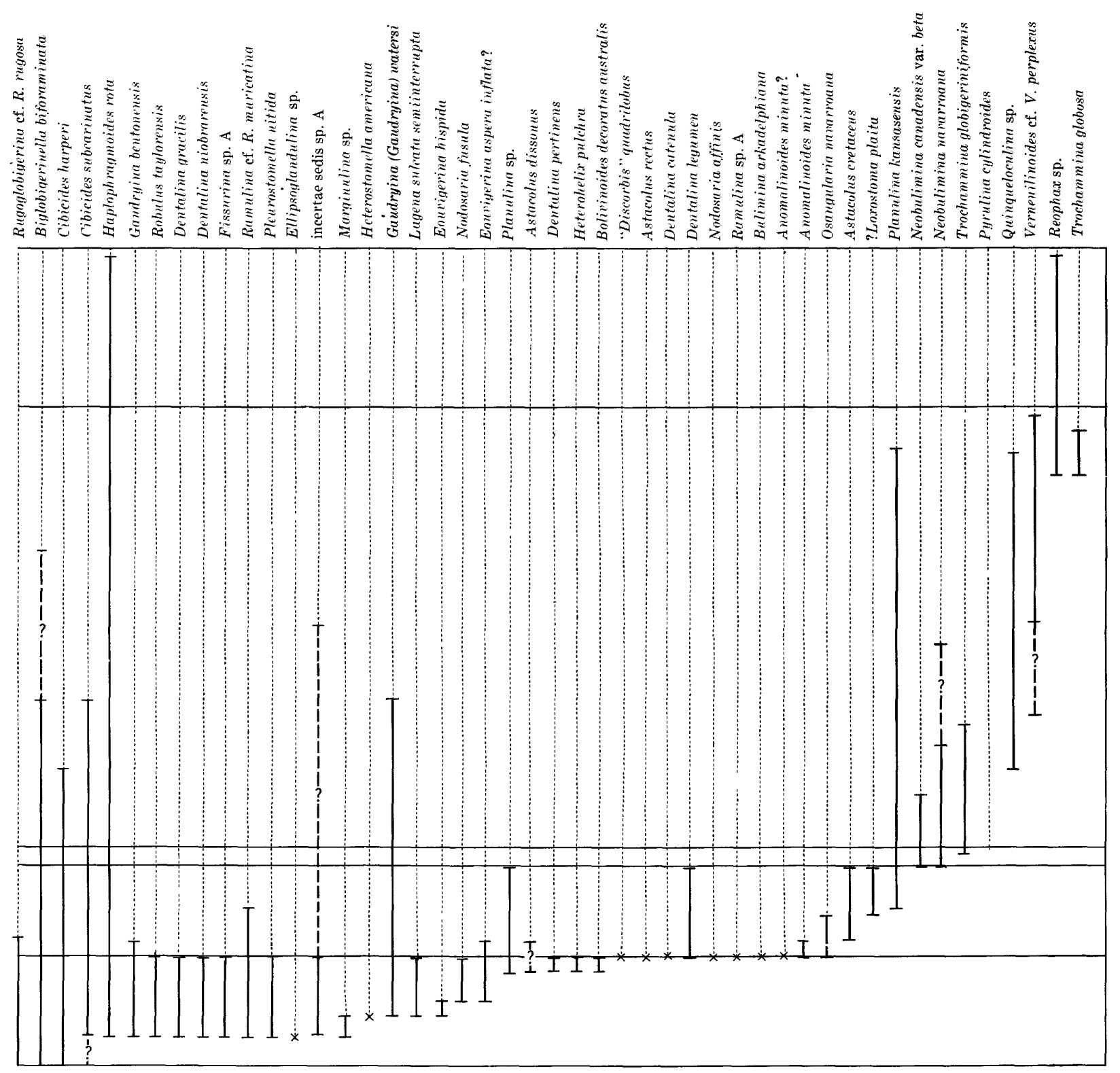

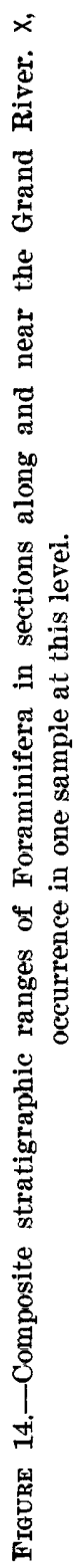


FORAMINIFERA, STRATIGRAPHY, PIERRE SHALE, FOX HILls SANDSTONE, S. DAK.

are assignable to his "Bottom living; stagnant? ; brackish or marine" environment (based on the dominance of arenaceous genera, including Haplophragmoides and Bathysiphon). That part of the Pierre calcareous biofacies dominated by genera, species, and specimens of Buliminidae would seem to belong in Lowman's "Upper part of continental slope (inner bathyal)" environment where there is a "Dominance of Buliminidae, especially Uvigerina and Bolivina." The part of the Pierre calcareous biofacies dominated by genera and species (but not specimens) of Lagenidae would seem to belong in Lowman's "Outer continental shelf (outer neritic)" environment, where there is a "Great abundance of genera and species; conspicuous number and variety of Lagenidae." The approximate depth ranges given by Lowman (1949, fig. 12, p. 1952) for these environments are: bottom living; stagnant (?) environment, about 0 to 20 feet; outer neritic environment, about 75 to 200 feet; and inner bathyal environment, about 200 to 1,500 feet. It should be pointed out that Lowman recognized two other marine environments in the depth range 0 to 75 feet, characterized by groups that are absent or inconspicuous in the upper Pierre and lower Fox Hills faunas. Thus, when the familial patterns for the Cretaceous Foraminifera are compared with Lowman's synthesis of Recent distributions, it is possible to infer a maximum depth of 200 to 1,500 feet and a minimum depth of 0 to 20 feet for the environment of deposition of the upper part of the Pierre and the lower part of the Fox Hills. When a comparison of Lowman's complete sequence of faunas is made with the Cretaceous patterns, however, there is little total agreement. If the interpretation that the calcareous and then the upper arenaceous biofacies were deposited under gradually shoaling conditions is accepted, one difference is that the buliminid-dominated and lagenid-dominated faunas are in reversed order. To put these faunas in their Recent order would require deepening water through this stratigraphic interval, and this does not seem likely. In any case, the close stratigraphic relationship between the buliminid and lagenid faunas suggests that the minimum water depth of 200 feet rather than the maximum of 1,500 feet is probably closer to being correct.

Albritton, Schell, Hill, and Puryear (1954) dealt with faunas at the family level at least in part comparable with those of the upper part of the Pierre Shale and lower part of the Fox Hills Sandstone. They treated the families on the basis of numbers of specimens, which I have not done, though it is possible to make approximate comparisons. These fossil faunas are also interpreted in terms of Lowman's Gulf of Mexico data. Their paper deals with Foraminifera from the Lower Cretaceous Grayson Marl of Texas and is of in- terest because the familial compositions of the faunas are somewhat similar to those of this stud\%. They described a shallow-water benthonic foraminiferal biofacies composed mainly of arenaceous genera and species and a deeper benthonic biofacies composed mainly of specimens of calcareous genera and species. In the deeper benthonic facies, specimens of Buliminidae are dominant at one stratigraphic level, and specimens of Lagenidae, Rotaliidae, and Anomalinidae combined are dominant at two stratigraphic levels. The main similarity between the Grayson and the upper part of the Pierre and lower part of the Fox Fills is that in both there are faunas characterized by arenaceous specimens, by specimens of Buliminidae, and by a more diverse assemblage containing varied forms of Lagenidae. In both the Grayson and the upper part of the Pierre Shale, the assemblages that lie batween the lagenid and arenaceous assemblages in the Gulf of Mexico are absent.

Other data on the distribution of Recent foraminiferal faunas were provided by Phleger (1960b, p. 280281 ), who discussed the general features of the foraminiferal faunas of the Gulf of Mexico. He characterized, in a generalized manner, the funas known from several environments in terms of number of species, number of genera, population size, planktonic-benthonic ratio, percentage of arenaceous forms, and characteristic genera. The number of genera and specios, the estimated planktonic-benthonic ratios, and the estimated percentage of arenaceous specimens present in some samples from all three foraminiferal biofrcies in the upper part of the Pierre Shale were determined for use in comparison with Phleger's data. Intermediate number values were given to the estimated abundarces of each species in a sample (see species descriptions for original abundance estimates) in order to provide numbers that could be compared with Phleger's data. Sixty-seven samples from the upper part of the Pierre Shale were analyzed, and the results are given in table 2 . The averages for the samples from the upper and lower arenaceous biofacies, despite small differences between them, much more closely resemble each other than they do the samples from the calcareous biofacies Also, the differences between the averages for samples of the calcareous biofacies that contain one to 10 species and 11 or more species are much less than are the dif erences between the calcareous biofacies averages as a whole and the averages of either of the arenaceous biofacies. The characteristics of the upper and lower arenaceous biofacies expressed in table 2 are most closely comparable with characteristics of faunas that Phleg?r grouped under the designations "Marine Marsh" and "Coastal Lagoon" environments, except for the fact that the 
TABLE 2.-Analysis of the number of genera, number of species, planktonic-benthonic ratios, and percentage of arenaceous specimens in 67 samples from the upper part of the Pierre Shale representing the three recognized foraminiferal biofacies

[Abundances used in compiling planktonic-benthonic ratios and average percentage of arenaceous specimens are estimates]

$\begin{array}{ccccc}\begin{array}{c}\text { Average } \\ \text { number } \\ \text { of genera } \\ \text { per } \\ \text { sample }\end{array} & \begin{array}{c}\text { Average } \\ \text { number } \\ \text { of species } \\ \text { per } \\ \text { sample }\end{array} & \begin{array}{c}\text { Average } \\ \text { planktonic- } \\ \text { benthonic } \\ \text { ratio per } \\ \text { sample }\end{array} & \begin{array}{c}\text { Average } \\ \text { percentage } \\ \text { of arena- } \\ \text { ceous } \\ \text { specimens } \\ \text { per sample }\end{array} & \begin{array}{c}\text { No. } \\ \text { of } \\ \text { ples- }\end{array} \\ & & & & \end{array}$

\begin{tabular}{|c|c|c|c|c|c|}
\hline Upper arenaceous bio- & 2.8 & & 10 & 95.7 & \\
\hline Calcareous biofacies 2 & $\begin{array}{l}2.0 \\
7.4\end{array}$ & $\begin{array}{l}0.0 \\
7.7\end{array}$ & $1: 3.9$ & $\begin{array}{l}9.8 \\
14.8\end{array}$ & 13 \\
\hline Calcareous biofacies 3 ..... & 17.3 & 21 & $1: 8.4$ & 7.1 & 27 \\
\hline $\begin{array}{c}\text { Total calcareous } \\
\text { biofacies } \\
\text { Lower arenaceous bio- }\end{array}$ & 14.1 & 16.6 & $1: 6.9$ & 8.8 & 40 \\
\hline facies & 6.8 & 6.8 & $1: 350$ & 67.5 & 10 \\
\hline
\end{tabular}

This ratio is infinity because no planktonic specimens were found in these samples. Samples of one to 10 species.

Samples of 11 or more species.

dominant genera are not the same. The characteristics of the samples from the calcareous biofacies most closely resemble the characteristics of Phleger's "Inner Continental Shelf" environment, again except for a difference in dominant genera. Phleger (1960b, p. 267), gave a depth range of 0 to 30 fathoms for the inner continental-shelf environment.

The application of Recent occurrence data to Cretaceous formainiferal faunas is subject to question. Phleger (1960b, p. 280) prefaced his data with a word of caution, and it is known that the planktonicbenthonic ratios given by Phleger do not hold for Recent faunas in some places in the Gulf of Maine (Thomas G. Gibson, written commun., 1963). Nevertheless, similarities between the Pierre faunas and those from the Gulf of Mexico are suggestive, and it is probable, from this line of evidence, that the Foraminifera from the upper part of the Pierre Shale and lower part of the Fox Hills sandstone lived in waters that were not deeper than about 200 feet.

Linguloid brachiopods, sporadically present in samples from 20 feet below the lower key bentonite to 37 feet above the base of the Fox Hills sandstone, may also be used as environment indicators. Cooper (1937, p. 30) reported that Recent linguloid brachiopods live from the tidal zone to depths of about 100 feet. They are presently found in tropical and warm-temperate waters (Allan, 1936, p. 384) and are not tolerant of fresh or brackish water for more than a few hours at a time (Rudwick, 1965, p. H211).

This attempt to use biologic data in environmental interpretation has yielded the following results:

1. Some characteristics of the three foraminiferal biofacies are elucidated by familial compositions, numbers of genera and species, planktonic-benthonic ratios, and percentages of arenaceous speci- mens in a group of upper Pierre-lower Fox Hills samples. These comparisons indicate:

a. that the lower and upper arenaceous biofacies are quite similar;

b. that the calcareous biofacies differs markedly from the two arenaceous biofacies.

2. Comparison with data on the distribution of Recent Foraminifera in the Gulf of Mexico indicates that the upper Pierre-lower Fox Hills faunas lived in waters that probably did not exceed about 200 feet in depth and that the faunas of the arenaceous biofacies lived at considerably shoaler depths.

3. The ecology and inferred paleoecology of linguloid brachiopods suggests that the strata containing them (from 20 feet below the lower key bentonite. to 37 feet above the base of the Fox Hills sandstone) were laid down in warm water of normal salinity at depths not greater than about 100 feet.

\section{LITHOLOGIC INFORMATION}

The upper part of the Pierre Shale is typically very fine grained and homogeneous with no megascopically apparent sedimentary structures. A sufficiently high content of calcium carbonate to cause a visible reaction with dilute hydrochloric acid is characteristic of the middle part of the stratigraphic sequence. Silt and sanc are apparently irregularly distributed through the shale and form barely distinguishable discontinuous layers along which the shale parts. In the upper part of the sequence, near the contact with the Fox Hills Formation, layers of silty and sandy shale become more commor and are thicker. The lower part of the Fox Hills Sandstone is typically a clayey sandy silt with more clay ir the lower part and more sand in the upper part.

A grain count of the constituents of the coarsegrained sediment fraction $(0.074 \mathrm{~mm}$ and larger $)$ was made for each sample examined for microfossils. The coarse-grained fraction generally composed only onefiftieth to one-one hundredth of the original sample, except for those samples from the upper part of the Elk Butte Member and from the lower part of the Fox Hills Sandstone, where sand-sized grains were more common. Quartz, pyrite, clayey calcareous and noncalcareous aggregates, and rusty aggregates of clay and silt were the most common grains found; fewer grains of glauconite, muscovite, biotite, Foraminifera, carbonized plant fragments, and other materials were also present. Glauconite, muscovite, and carbonized plant fragments are usually found only in the uppermost part of the Elk Butte and in the lower part of the Fox Hills. Glauconitc is almost always associated with quartz grains of ap. proximately the same size, a fact suggesting that the glauconite was probably not authigenic. The carbonized 
FORAMINIFERA, STRATIGRAPHY, PIERRE SHALE, FOX HILLS SANDSTONE, S. DAK.

plant fragments are never more than 5 percent of the total coarse fraction, and muscovite is generally less than 20 percent. Foraminifera are usually very few in samples containing muscovite and carbonized plant fragments.

\section{RECENT ANALOGS}

An attempt has been made to find faunal and lithologic similarities between the strata studied for this report and sediments being laid down at present. Because of inferred shallow-water and relatively nearshore conditions during deposition of these strata, comparisons have been made with Recent near-shore and continentalshelf deposits. Many modern outer-shelf environments are poorly suited for comparison because of the presence of anomalous sediments laid down during the lowered sea level of the Pleistocene.

Reports on the nearshore and continental-shelf deposits of the Mississippi delta (Shepard, 1956; Scrutoll, 1960), the Texas Gulf Coast (Shepard and Moore, 1955), the Paria-Trinidad shelf (Koldewijn, 1958), the western Guiana shelf (Nota, 1958), and the East China and South China Seas (Niino and Emery, 1961) were examined. In each of these areas, grain size decreases seaward, and calcium carbonate content increases seaward, at least to the point where Pleistocene deposits begin. In each of these modern areas the number of species and specimens of Foraminifera per gram of dry sediment (foraminiferal number) increases offshore, as does the proportion of planktonic specimens. Along the western Guiana shelf, a shallow depth zone paralleling the shore contains no Foraminifera, and in the other areas mentioned above, small foraminiferal numbers nearshore are usual. This foraminiferal distribution in a horizontal plane from offshore to nearshore is analogous to the vertical distribution in the strata studied from the base of the calcareous biofacies to the top of the upper arenaceous biofacies.

In discussing the marginal deposits of the Mississippi delta, Shepard $(1956$, p. 2537$)$ reported the presence of abundant wood fibers and mica and a low foraminiferal number in the foreset deposits. Foraminiferal number increases and wood fibers and mica decrease away from shore in the lower foreset and bottomset beds. Abundant wood fibers were also reported in the nearshore silty pelites on the western Guiana shelf (Nota, 1958, p. 38, 39 ), but they are much less common in the offshore pelites. Muscovite and carbonized plant fragments are most abundant in the upper part of the upper arenaceous biofacies, and foraminiferal number is low. Both muscovite and plant fragments decrease and foraminiferal number increases as the Cretaceous section is descended. Thus, changes that occur in these parameters in modern areas from nearshore to offshore are analo- gous to the same changes occurring in the upper arenaceous biofacies from its top in the lower part. of the Fox Hills Sandstone downward into the Elke Butte Member of the Pierre Shale.

\section{CONCLUSIONS}

The limited areal and stratigraphic nature of this investigation prechudes definitely relating the environments represented to any specific Recent analog. The biologic comparisons also do not closely def ne environments. However, the lithologic and biologic data do suggest that the vertical changes occurring from about the base of the Mobridge Member through the lower part of the Fox Hills Sandstone are analogous. in general, to the changes that occur from inner continental-shelf depths to nearshore in some areas of Recent deposition. Additional observations and inferences can be made on the more local aspects of the upper part of the Pierre and lower part of the Fox Hills environments.

The faunas of the upper arenaceous biofacies lived in shallow water. The increasing percentages of fossil plant fibers and muscovite and the decreasing foraminiferal number toward the top of the biofacies indicate an increasingly close approach to shore. Increase in the sand-silt content of the strata towards the tcp of the biofacies indicates that the sea bottom had come into an environment of higher energy. Recent bracl-ish marshes and lagoons discussed by Phleger (1960a, p. 258) support exclusively or predominantly arenaceous faunas, and it is possible, though not likely, that the faunas of the upper arenaceous biofacies lived in waters of lowered salinity. Lowered salinity has been suggested as the factor responsible for the small predominantly arenaceous faunas in the Triassic beds of the Arctic slope of Alaska (Tappan, 1951, p. 3) and tho Cretaceous Thermopolis Shale (Eicher, 1960, p. 48).

It is possible that increased turbidity inhibited the growth of calcareous Foraminifera or that increased turbulence exposed abandoned tests to the water a sufficient number of times to promote complete dissolution. Introduction of more organic material from land may have produced toxic conditions which could not be tolerated by most calcareous species, or the anaerobic destruction of this material within the sediment may have produced acidity which destroyed calcareous test.s. Also, the population of arenaceous Foraminifera may have filled the normal nearshore niche today occupied by the calcareous species Elphidium, Ammonia, and Buccella. In short, although various authors explaired the presence of largely or totally arenaceous fossil foraminiferal faunas as probably due to lowered salinity, this does not seem to have been the cause of the arenaceous nature of the foraminiferal faunas in the upper arenaceous bio- 
facies, and other possible but unverified explanations are suggested.

The composition of the faunas of the calcareous biofacies indicates that they lived in rather shallow water, although deeper than that in which the upper arenaceous biofacies lived. The scarcity of silt and sand in the enclosing shale indicates that the sea bottom was not affected by strong winnowing currents. The size and diversity of the faunas suggest that the bottom waters were well aerated and of normal salinity.

The small predominantly arenaceous foraminiferal faunas which compose the lower arenaceous biofacies present certain difficulties in interpretation. The similarities of these faunas with those of the upper arenaceous biofacies, at least in terms of the comparisons made in this study, suggest similar environments. On the other hand, the presence of abundant Radiolaria, the filling of calcareous specimens with silica, and the numerous thin bentonite beds in strata containing the lower arenaceous foraminiferal biofacies contrast markedly with the strata containing the upper arenaceous biofacies where these features are absent. The Radiolaria themselves seem not to have occupied a restricted niche because they also occur in the upper arenaceous biofacies, in the Fox Hills Sandstone, and in shales of the calcareous biofacies. In this case, they certainly do not indicate water of abyssal depth. The undisturbed nature of the bentonite beds in the strata of the lower part of the biofacies indicates that bottom-disrupting currents were not operative. However, the presence of several thin and laterally persistent bentonite beds in the lower part of the Fox Hills Sandstone indicates that lack of disruption is not a criterion of deep water (Fox Hills data from Karl M. Waagé, written commun., 1963). In short, no unequivocal lithologic evidence of deposition of the Virgin Creek shale in deeper water has been observed. The upper and lower foraminiferal biofacies probably had similar living conditions, which may indicate a shallow depositional depth for the Virgin Creek, as for the upper part of the Elk Butte Member and lower part of the Fox Hills Sandstone. It is not possible, on the faunal evidence, to do more than suggest this because similarities of fauna may be due to those of environment independent of water depth. A brackishwater environment is considered unlikely for the upper arenaceous biofacies because linguloid brachiopods, sporadically present throughout, are not found in brackish water today and because the diversity of the benthonic and nektonic molluscan fauna in the upper beds (Fox Hills Sandstone) containing this biofacies is atypical of a brackish-water environment.

One can postulate a general sequence of events in the deposition of the upper part of the Pierre Shale. The strata containing the lower arenaceous biofacies are assumed to have been deposited in rather shallow water, but the locale of deposition must have been far enough offshore not to receive noticeable quantities of plant fibers and mica. Alternatively, it could be assumed that these strata were deposited at the same or greater depths than those in which the strata of the calcareous biofacies accumulated and that faunal similarities between the lower and upper arenaceous biofacies are depth-independent or fortuitous. In either case the rapid transition from the lower arenaceous to the calcareous biofacies indicates a rather rapid change in environmental conditions. If the first assumption is accepted, this change may have been due to deepening, possibly in conjunction with an advance of the Cretaceous sea. If the second assumption is accepted, the change may have been due to environmental changes not related to depth. The gradual decrease in faunal size and diversity in the upper part of the calcareous biofacies and the gradual transition to the overlying upper arenaceous biofacies indicate shallowing through this time interval. The upper arenaceous biofacies was deposited in increasingly shoaling water, as shown by the nature of the fauna and by the sedimentologic and lithologic changes that take place upward, culminating in the deposition of the very nearshore sands and silts of the lower part of the Fox Hills Sandstone.

\section{PALEONTOLOGY}

\section{LABORATORY METHODS}

Samples were usually taken at 5-foot 9-inch intervals, but generally only every other sample was examined for microfossils. These samples were processed by the following methods: One-quarter pound $(113.4 \mathrm{~g})$ of the largest pieces of rock in each sample were boiled in a weak solution of sodium hexametaphosphate and water until broken down. The mud was washed through a 200-mesh sieve (openings of $0.074 \mathrm{~mm}$ ). The residue was dried, weighed, and bottled. Few samples left a residue of more than $2 \mathrm{~g}$, and most left less than $1 \mathrm{~g}$. Of this amount approximately 0.1 to $0.15 \mathrm{~g}$, or the equivalent of about 6 to $17 \mathrm{~g}$ of shale, was examined under the microscope. Before any specimens were picked, at least 100 randomly encountered grains of residue, including fossils, were counted and assigned to categories on the basis of mineralogy or other distinguishing characteristics.

Magnetic separation of Foraminifera from ferruginous residue was successful for nearly all samples on which it was tried. This method removed at least 50 percent and sometimes as much as 90 percent of the ferruginous particles from the residue. The loss of specimens that were preserved as ferruginous internal molds 
or that contained pyrite was more than compensated for by the many-fold concentration of unfilled tests. However, it was impractical to separate either calcareous or arenaceous Foraminifera from a quartz-rich residue by this method.

After picking, sorting, and mounting the Foraminifera, estimates of species abundance were recorded. These were the estimated number of specimens of each species seen in the course of picking the 0.1 to 0.15 gram of residue examined. Nine abundance categories were established. The estimates are comparable for most samples because in all samples except those from the siltier upper part of the Elk Butte Member and lower part of the Fox Hills Sandstone, weight percentages of residues were comparable.

\begin{tabular}{|c|c|}
\hline Category & Specimens and symbol \\
\hline Abundant & $>1,000(\mathrm{~A})$ \\
\hline Very common & $500-1,000(\mathrm{VC})$ \\
\hline Common_.......... & $150-499(\mathrm{C})$ \\
\hline Rather common $\ldots$ & 50-149 (RC) \\
\hline Rather rare & 20-49 (RR) \\
\hline Rare & $10-19(\mathrm{R})$ \\
\hline Very rare & $4-9(\mathrm{VR})$ \\
\hline Scarce & $2-3(\mathrm{~S})$ \\
\hline Exclusive. & $1(X)$ \\
\hline
\end{tabular}

The estimated abundance of each species in the examined residue of each sample in which it occurs is given under "Occurrence" following each species description. Under "Material" is an estimate of the total number of specimens observed (although not necessarily picked), based on the total of the estimated abundances.

\section{MACROFOSSILS}

Listed below are the macrofossils that were collected and identified and the sections and stratigraphic horizons from which they came. Identifications were made chiefly by reference to the classic work on western interior invertebrates by Meek (1876). No comparative material was studied.

Locality

3 Baculites sp. $-41 \mathrm{ft}$ above base of section, $169 \mathrm{ft}$ below the lower key bentonite.

Ostrea pellucida Meek and Hayden and Inoceramus cf. I. cripsii? Mantell var. barabini Morton- $-32 \mathrm{ft}$ above base of section, $178 \mathrm{ft}$ below lower key bentonite.

4 Inoceramus sp.- - float.

7 Lucina sp., Nuculana ef. N. bisulcata Meek and Hayden, and hamulid worm tubes- $56 \mathrm{ft}$ above base of section, $48 \mathrm{ft}$ below lower key bentonite.

Inoceramus fibrosus (Meek and Hayden)-148 $\mathrm{ft}$ above base, $43 \mathrm{ft}$ above lower key bentonite.

Baculites sp. $-51 \mathrm{ft}$ above base, $53 \mathrm{ft}$ below lower key bentonite.

Linguloid brachiopods, in samples $17,19,23,25,27$, and 29 , range from $14 \mathrm{ft}$ below the lower key bentonite to directly below the level of the upper key bentonite.
Locality

Callista? ef. C. pellucida Meek and Hayden--60 ft above base of section, $21 \mathrm{ft}$ above lower key bentonite.

Scaphites sp.-76 ft above base of section, $37 \mathrm{ft}$ above lower key bentonite.

11 Linguloid brachiopods, from sample 3, directly above the upper key bentonite.

13 Inoceramus fibrosus (Meek and Hayden) and Scaphites sp.-from 85 to $110 \mathrm{ft}$ above base of section, from 34 to $59 \mathrm{ft}$ above lower key bentonite.

20 Lucina? sp.-16 $\mathrm{ft}$ above base of section, $29 \mathrm{ft}$ below upper key bentonite.

27 Scaphites? sp.-at base of section, $20 \mathrm{ft}$ belc $\mathrm{N}$ the upper key bentonite.

Linguloid brachiopods, in samples $3,6,9$, and 10 , range from just below to $35 \mathrm{ft}$ above the upper key bentonite.

27A Discoscaphites sp. $-108 \mathrm{ft}$ above base of section, 12 feet below the base of the Fox Hills Sandstone.

Linguloid brachiopods, in samples $2,3,5,6,7,11,12$, $14,15,17,18,19$, and 23 , range from 84 ft below to $32 \mathrm{ft}$ above the base of the Fox Hills Sandstone.

31 Drepanochilus americana (Evans and Shumard), Goniomya americana Meek and Hayden, Discoscaphites sp., Pteria linguiformis (Evans and Shumard), and Lunatia cf. L. concinna (Hall and Meek)-top of the section, $107 \mathrm{ft}$ above the base of the Fox Hills Sandstone.

Linguloid brachiopods, in samples $1,3,5,7(?)$, and 9, range from $45 \mathrm{ft}$ below to $11 \mathrm{ft}$ below tl 9 base of the Fox Hills Sandtone.

36 "Serpula" wallacensis Elias of Searight (1937, p. 38), and Baculites cf. B. grandis Hall and Meek-fossils scattered through the section; stratigrapl ic position of the section not precisely known but bylieved to be 50 to $150 \mathrm{ft}$ below the lower key bentonite.

37 Baculites cf. B. clinolobatus Elias and Scaphites sp.-fossils scattered through the lower $40 \mathrm{ft}$ of the section, from 0 to $40 \mathrm{ft}$ below the lower key bentonite.

39 Drepanochilus sp.- - on the basis of the mirrofauna, this short section appears to lie 50 to $100 \mathrm{ft}$ below the lower key bentonite.

41 Baculites cf. B. clinolobatus Elias and Inoceramus sp.fossils occur from base of section to approximately 45 feet above the base, 5 to $50 \mathrm{ft}$ below the lower key bentonite.

Linguloid brachiopods, in samples $1,3,5$, and 7 , range from $32 \mathrm{ft}$ below to directly below the lower key bentonite.

49 Linguloid brachiopods, in samples $1,3,5.7,9,11,13$, and 15 , range from directly above to $53 \mathrm{ft} 10$ inches above the upper key bentonite.

50 Discoscaphites nicolleti (Morton) -2 to $9 \mathrm{ft}$ above the base of the Fox Hills Sandstone.

Gervillia sp. -24 to $30 \mathrm{ft}$ above the base of the Fox Hills Sandstone.

Protocardia sp. $-40 \mathrm{ft}$ above the base of the Fox Hills Sandstone.

52 Linguloid brachiopods, in sample 3, $28 \mathrm{ft}$ klow the base of the Fox Hills Sandstone.

54 Linguloid brachiopods, in samples $1,3,5,7,9$, and 13 , present at all sampled levels in the secticn.

The above is by no means a complete list of the occurrences of macrofossils in the upper part of the Pierre Shale. Macrofossils are generally rare and rore difficult 
to find in this part of the section than they are in the overlying Fox Hills Sandstone; not all those found were collected and identified. The scaphitid ammonites from the upper part of the Pierre were examined by $\mathrm{K}$. M. Waagé and are believed by him to represent undescribed species or subspecies. Also, because no concerted effort was made to collect macrofossils from the Fox Hills Sandstone, only a few of the many genera and species present in this formation are listed here.

\section{OSTRACODES}

A small suite of ostracodes from the upper part of the Pierre Shale was submitted to I. G. Sohn of the U.S. Geological Survey for identification. Below is a list of genera and species identified and the localities from which they came.

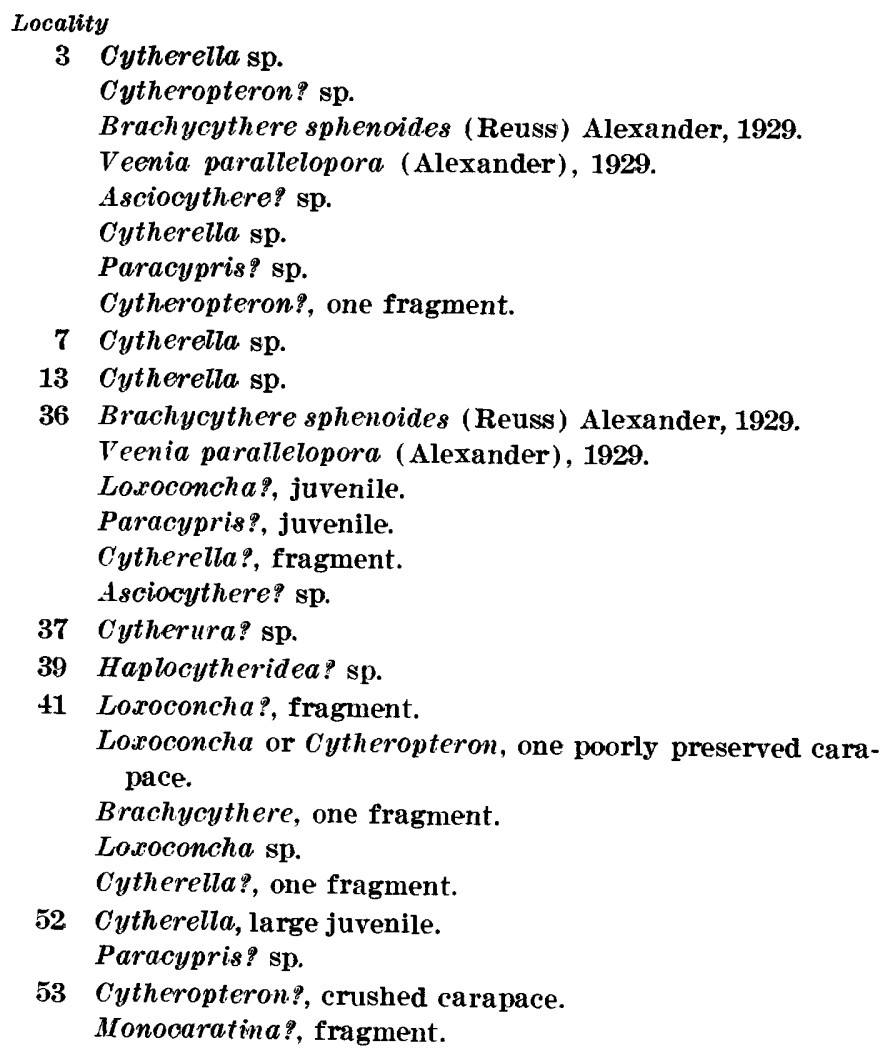

In addition to the ostracodes, Sohn identified ophiuroid ossicles from locality 36 , sample 3 , and locality 52 , sample 3.

\section{CLASSIFICATION AND TAXONOMY OF FORAMINIFERA}

The classification used here is essentially that of Cushman (1948b), although a number of modifications have been adopted. One advantage to this classification is that most of the work on Foraminifera over the past 30 years or so has been either in terms of this classification or its somewhat more simplified earlier versions; thus more direct faunal comparisons can be made. Another advantage is that this classification, based as it is on relatively few morphologic features, is easy to use and quite flexible. Several classifications of Foraminifera have been published in recent years; the more important are based at least in part on test composition and features of morphology that are more difficult to observe but that are considered to be of basic importance. The best documented recent classification is that of Loeblich Tappan, and others (1964). This impressive work was published too recently to permit application to the faunas discussed here.

Taxonomically, the familial and generic distinctions are adopted from Cushman, with several exceptions. The large number of taxa made it impossible to investigate the taxonomy of all genera and families, although several genera were analyzed in detail.

For most species the dimensions of one or a few specimens, visually determined to be of average size for the Pierre specimens, were measured as described below. The measurements are in no way statistical averages; they are meant only to give a general idea of the sizes of the several species. Measurements were made with a binocular microscope and screw micrometer eyepiece at a magnification of $\times 50$.

1. On planispiral and low trochospiral specimens:

Maximum diameter.-The greatest distance between opposite peripheries measured perpendicular to the axis of coiling along a line passing across the center of the umbilicus or axis of coiling. One end of the line usually terminates at the outer periphery of the final chamber.

Minimum diameter.-The least distance between opposite peripheries measured along a line passing across the center of the umbilicus or axis of coiling. One end of the line usually terminates at the periphery of the first chamber in the fina] whorl.

Diameter.-Measured in the same plane as maximum and minimum diameter along a line passing through the center of the umbilicus or axis of coiling and used for species in which there is no appreciable difference between diameters.

Thickness.-The greatest distance observed in the, horizontal plane which includes the umbilicus or axis of coiling when the specimen is oriented with the axis of coiling and apertural face ir the vertical plane. This is usually a measure of the distance across one of the last few chambers in the final whorl in planispirally coiled forms or of the height of the spire in trochospirally coiled forms. 
FORAMINIFERA, STRATIGRAPHY, PIERRE SHALE, FOX HILls SANDSTONE, S. DAK.

2. On elongate flattened specimens:

Length.-Distance along the axis of elongation.

Breadth.-Greatest distance in the plane of compression and perpendicular to the axis of elongation.

Thickness. - Greatest distance perpendicular to the plane of compression.

3. On elongate cylindrical specimens, including hightrochospiral specimens:

Length.-Distance along the axis of elongation.

Breadth.-Greatest distance perpendicular to the axis of elongation.

4. On single-chambered specimens:

Height.-Distance from the aperture to the base of the chamber. This is the only dimension in globular tests.

Breadth.-Greatest distance in the plane of compression and perpendicular to the axis of height or, in cylindrical forms, the greatest distance perpendicular to the axis of height.

Thickness.-As defined in (2) above, if the chamber is compressed.

Almost all taxa, including those that could not be identified to species, are described, with the exception of a few well-known and frequently cited species. All identified species and most of those that could not be identified to species are illustrated. Photographs illustrate most species, but drawings are used for the new species and for a few others. Retouching of photographs was done by me or by Mrs. Elinor Stromberg under my direction.

\section{Family RHIZAMMINIDAE}

Genus BATHYSIPHON M. Sars, 1872

Bathysiphon brosgei Tappan?

Plate 4, figure 1

Test single chambered, elongate, cylindrical or compressed, with occasional constrictions; compressed specimens often with a troughlike central depression due to the collapsing of the wall into the central cavity; wall thick in larger specimens, rather thin in some smaller specimens, and consists of amorphous noncalcareous cement and silt grains in widely varying proportions, the texture ranging from smooth to very rough; aperture, the open end of the tube. Dimensions of average-sized specimens : length, about $0.7 \mathrm{~mm}$; breadth, about $0.2 \mathrm{~mm}$ (crushed).

Remarks.-The most distinctive characteristic of these specimens is the range of variation in wall composition. The proportions of amorphous cement and silt grains vary considerably. Amorphous material composes all the wall in most smaller specimens and virtually all

in some larger specimens. Quartz grains with a minor amount of cement compose the wall in other Targe specimens and in some smaller specimens. Series of specimens have been found that exhibit all stages between the two extremes.

Silt particles are all approximately the same size in each test. Grain size does not appear directly related to test size; some of the narrowest specimens ar? composed of very coarse grains, whereas some of the wider and presumably more mature tests are composed of rather fine grains.

Specimens composed entirely of amorphous material may be as thick walled as coarsely arenaceous specimens, though in general they are more delicate and some exhibited thin translucent walls.

The range of variation of the upper Pierre and lower Fox Hills specimens, coupled with the scarcity of diagnostic criteria to identify species of this genus, makes it difficult to determine the species to which these specimens should be assigned. The more common smoothly finished specimens resemble Bathysiphon brosgei Tappan (Tappan, 1957, p. 202, pl. 65, figs. 1-5). The larger smooth specimens resemble what Tappan (1962, p. 128) referred to as B. vitta Nauss. Because of the gradational sequence that the upper Pierre and lower Fox Hills specimens exhibit, all the specimens are tentatively assigned to B. brosgei Tappan. All specimens are incomplete.

Occurrence.-Bathysiphon brosgei Tappen has previously been reported from the Cretaceous of Alaska, where it is found throughout the Colville and Nanushuk Groups and in the underlying Fortres: Mountain Formation (Tappan, 1957, p. 202; 1962, p. 128) ; from shales of Coniacian and Santonian ages in the Redding area, Shasta County, Calif.; and from the Holz Shale Member of the Ladd Formation of late Turonian to early Campanian ages in the Santa Ana Mountains, Calif. (Trujillo, 1960, p. 302).

The species occurs at nearly all levels in the upper part of the Pierre Shale and lower part of tho Fox Hills Sandstone. It is usually scarce but occasionally becomes an abundant element in the fauna.

Material.-Several hundred specimens rere found.

\begin{tabular}{|c|c|c|c|}
\hline \multirow{4}{*}{ Locality } & Sample & Locality & Sample \\
\hline & $5-\mathrm{RR}$ & $7 \ldots$ & $3-\mathrm{X}$ \\
\hline & $7-V R$ & & 11 ?-VR \\
\hline & $9-\mathrm{R}$ & & $15-\mathrm{R}$ \\
\hline \multirow[t]{8}{*}{$3 \ldots \ldots \ldots$} & 1-RR & & 17-RR \\
\hline & $3-\mathrm{R}$ & & $23-\mathrm{X}$ \\
\hline & $5-\mathrm{RR}$ & $13 \ldots$ & $23-X$ \\
\hline & 9-RR & $20 \ldots$ & $17-V R$ \\
\hline & $11-\mathrm{RC}$ & $27 \ldots \ldots \ldots$ & $6-S$ \\
\hline & 14-RR & & $9-\mathrm{RC}$ \\
\hline & $16-X$ & $27 A_{\ldots} \ldots \ldots$ & $2-\mathrm{RC}$ \\
\hline & $18-\mathrm{RC}$ & & $3-V R$ \\
\hline
\end{tabular}




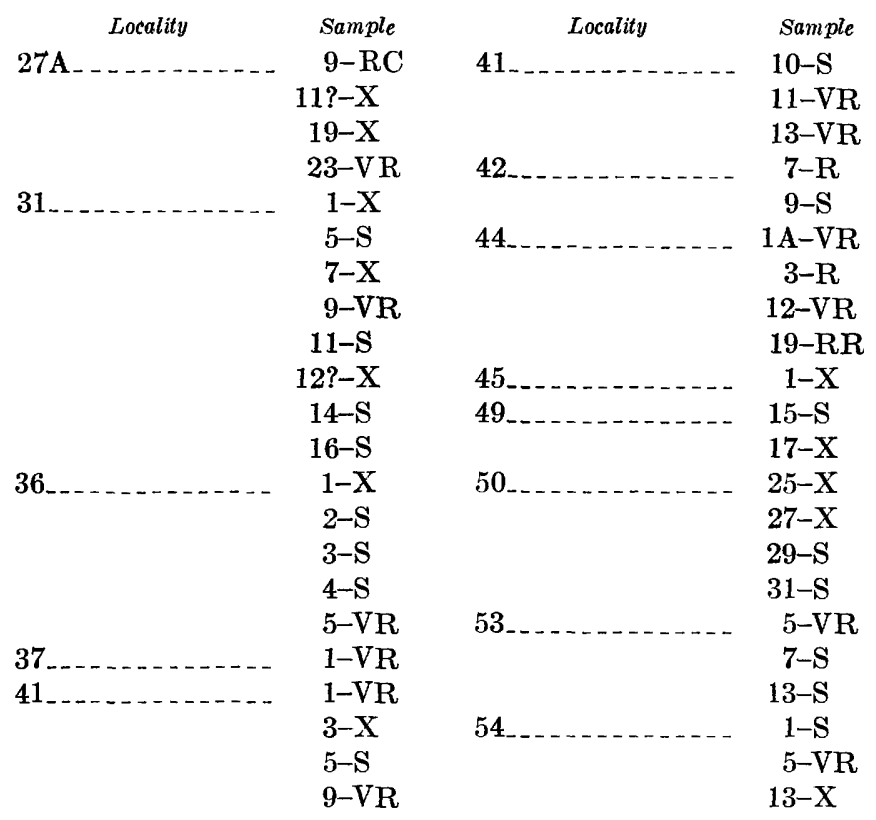

Family REOPHACIDAE

Genus REOPHaX Montfort, 1808

Reophax sp.

Plate 4, figure 2

Test incomplete or distorted in all specimens. The best specimens are rectilinear, uniserial, with globular partly overlapping chambers; wall composed of moderately coarse, angular silt grains, about 30 percent cement; surface smooth relative to the size of the grains composing the wall; aperture believed to be terminal but not positively identified in any of the few specimens having the final chamber preserved. Dimensions of average-sized specimens : length, about $0.7 \mathrm{~mm}$; breadth, about $0.2 \mathrm{~mm}$.

Remarks.-Although the specimens are typically crushed and broken, shape of the test and chambers indicates that they are in the genus Reophax. Lack of complete specimens and apertural details precludes specific identification. The specimens resemble $R$. minuta Tappan and $R$. arctica Brady in size, nature of the external globular chambers, and coarseness of wall composition. They are more closely similar to $R$. minuta Tappan than to any other Cretaceons species of this genus known to me.

Occurrence.-These specimens are found from 66 feet above to 74 feet below the base of the Fox Hills Sand. stone.

Material.-Fewer than 50 specimens were found.

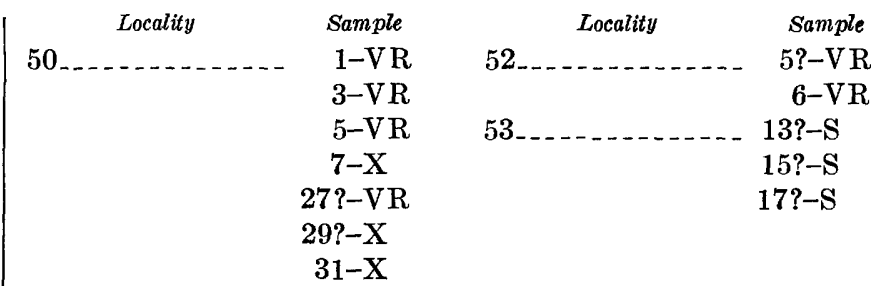

Family AMMODISCIDAE

Genus AMmodiscus Reuss, 1861

Ammodiscus cretaceus (Reuss)

Plate 4, figure 3

Operculina cretacea Reuss, 1845, Versteinerungen Böhmischen Kreideformation, pt. 1, p. 35, pl. 13, figs. 64, 65.

Cornuspira cretacea Reuss, 1860, Akad. Wiss. Wien, Matr.naturw. Kl. Sitzungsber., v. 40, p. 177, pl. 1, fig. 1.

Ammodiscus cretacea (Reuss). Cushman, 1934, Cushman Lab. Foram. Research Contr., v. 10, pt. 2, p. 45.

Test planispiral, biconcave, closely and uniformly coiled, partially involute; each succeeding whorl cover's about one-half the preceding whorl; chamber size increases gradually and uniformly, with many coils, commonly distorted in fossilization; suture distinct, depressed; wall fairly thick, composed completely of noncalcareous cement, surface matte textured, milky white; aperture the open end of the chamber, generally flattened or distorted by crushing. Dimensions of averagesized specimens: maximum diameter, about $0.5 \mathrm{~mm}$; minimum diameter, about $0.4 \mathrm{~mm}$; thickness, about 0.1 $\mathrm{mm}$.

Remarks.-The specimens included in this specier, like those included in Bathysiphon brosgei Tappan? exhibit a wide range in variation in wall thicknes?. Smaller, presumably less mature, specimens have thimner and more translucent walls than the associater larger specimens. Most specimens were distorted during compaction of the sediments, and many were flattened in the plane of coiling. Thinner walled specimens were flattened relatively more than thicker walled ones.

Occurrence.-This species has been reported from the Pierre Shale of South Dakota (Loetterle, 1937, p. 56), from the Riding Mountain Formation of Saskatchewan and Manitoba (Wickenden, 1945, p. 50), and from the Sentinel Hill Member of the Schrader Bluff Formation in Alaska (Tappan, 1962, p. 130, 131). Cushman (1946, p. 17) recorded it from beds of Austin, Taylor, and Navarro ages in Cretaceous deposits of the Gulf Coastr.l Plain. Since 1946, the species has been reported from a borehole penetrating Upper Cretaceous rocks near Salis- 
FORAMINIFERA, STRATIGRAPHY, PIERRE SHALE, FOX HILLS SANDSTONE, S. DAK.

bury, Md. (Cushman, 1948a, p. 245), and from the Arkadelphia Marl in Arkansas (Cushman, 1949, p. 2). In addition to these North American occurrences, $\mathrm{Am}$ modiscus cretaceus has been reported from the Cretaceous of France, the Netherlands, Germany, Spain, Poland, and Ireland, and also from Japan and Australia.

Specimens are generally few in any one sample but occur through the entire measured section.

Material.-Several hundred specimens were found.

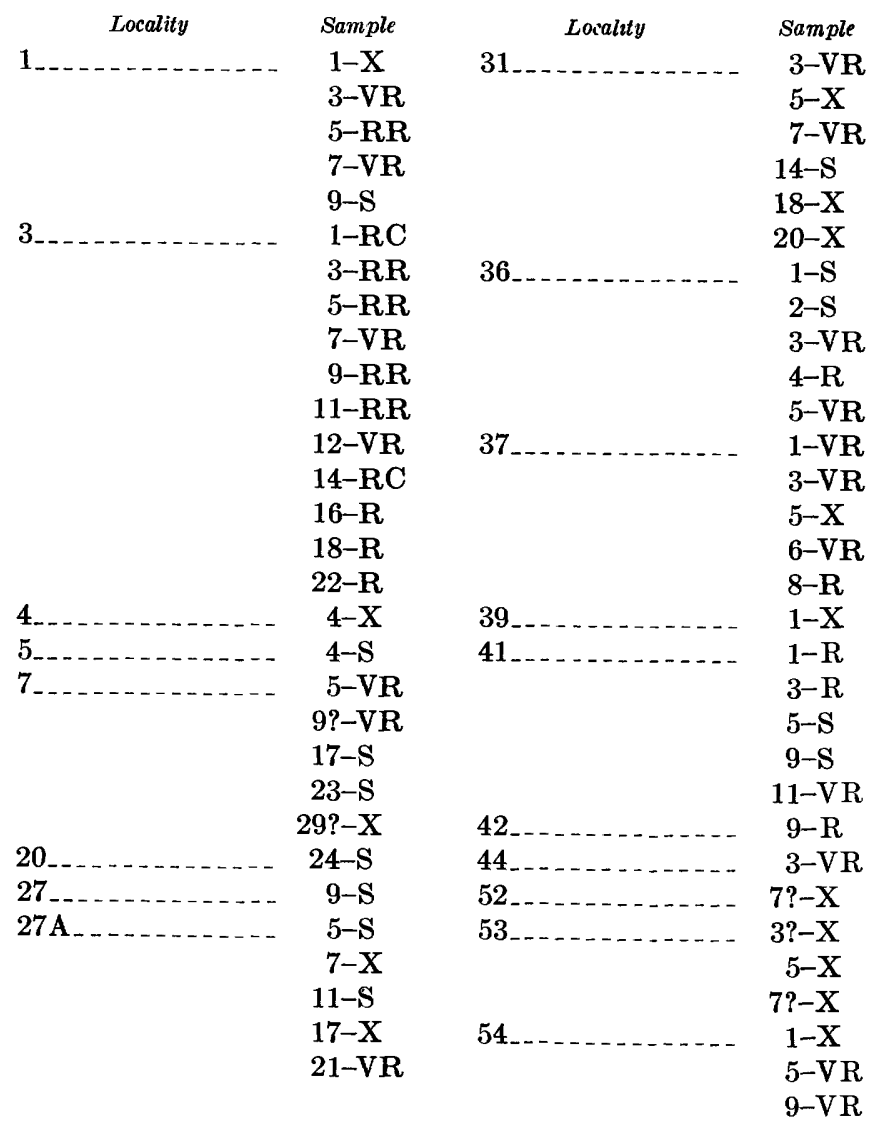

Genus GLOMOSPIRA Rzehak, 1888

Glomospira charoides (Jones and Parker)

Plate 4, figures $4 a, b$

Trochammina squamata var. charoides Jones and Parker, 1860, Geol. Soc. London Quart. Jour., v. 16, p. 304

Glomospira charoides (Jones and Parker). White, 1928, Jour. Paleontology, v. 2, no. 3, p. 187, pl. 27, fig. 7.

Test small, composed of a proloculus and an undivided tubular chamber which forms a low bell-shaped, rounded spire; in most specimens the area enclosed by the spire is occupied by a slightly protruding to slightly depressed convex lump of shell material; several other specimens are more discoidal, perhaps because of deformation; wall noncalcareous, composed of milky- white material, with no foreign particles visible; aperture formed by the open end of the chamber at the basal rim of the spire. Dimensions of average-sized specimens: thickness, about $0.1 \mathrm{~mm}$; diameter, about $0.25 \mathrm{~mm}$. All specimens distorted.

Remarks.-The specimens differ from Glomospira charoides var. corona Cushman and Jarvis in lacking the "crown" of irregular coils from which the variety takes its name. They differ from most other specimens of $G$. charoides which $\mathrm{I}$ have seen in being completely opaque rather than slightly translucent; as a result, the coiling pattern is not clearly accentuated in the Pierre specimens.

Occurrence.-Glomospira charoides var. corona has ben reported from the Pierre Shale of South Dakota (Searight, 1938, p. 135; Applin, 1933, p. 21.9). It has not been recorded from Upper Cretaceous deposits of the Gulf Coast. G. charoides has not previously been recorded from the United States, to my knovledge, but has been recorded from the Upper Cretaceous of Mexico (White, 1928, p. 187) and from the Cretaceous of Switzerland, Czechoslovakia, Germany, the Netherlands, Poland, England, and France.

In the upper part of the Pierre Shale of north-central South Dakota, this species is represented by a few specimens found 52 to 143 feet below the lower key bentonite in the Moreau River stratigraphic sequence.

Material.-About a dozen specimens were found.

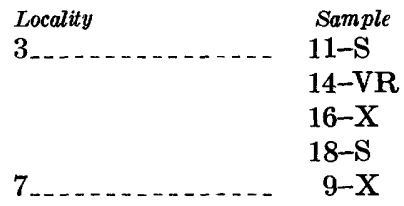

Family LITUOLIDAE

Genus HAPLOPHRAGMOIDES Cushman, 1910

Haplophragmoides rota Nauss

Plate 4, figures 5a, b

Haplophragmoides rota Nauss, 1947, Jour. Paleontology, v. 21, no. 4 , p. 339 , pl. 49 , figs. 1,3 .

Test planispiral, compressed, completely involute, with small shallow umbilici; periphery subacute, smooth to slightly lobulate; chambers rather indistinct, eight to 10 in the final whorl, slightly if at all inflated; sutures unrecognizable except where slightly depresse 7 between inflated chambers, straight to slightly convex toward the aperture; walls moderately coarsely arenacebus, rather smoothly finished, with relatively little cement, silt grains fairly well size sorted; aperture not well preserved, apparently a low silt between the brse of the apertural face and the underlying chamber; color white 
to rust tinted, generally the former. Dimensions of average-sized specimens : maximum diameter, about $1.0 \mathrm{~mm}$; minimum diameter, about $0.7 \mathrm{~mm}$; thickness, about 0.2 $\mathrm{mm}$. All specimens at least partly distorted.

Remarks.-Direct comparison of the Pierre and Fox Hill specimens with the holotype and paratypes or Haplophragmoides rota Nauss was not possible. However, hypotypes of this species from the Cretaceous of Alaska, designated by Tappan (1962, p. 134-135), compare well with some of the Pierre specimens in both the wellpreserved and deformed states.

Nearly all specimens of Haplophragmoides recovered in this study were distorted in one way or another. This added greatly to the difficulty of assigning the specimens to species. As a result, the assignments to $H$. rota have been much more subjective than for almost every other species; many specimens could only be tentatively assigned to this species. Furthermore, the distinction between small specimens of $H$. rota and average-sized specimens of $H$. bonanzaensis Stelck and Wall are often not clear cut. $H$. rota and $H$. bonanzaensis, at least as I have recognized them, may be variants of a single species.

Occurrence.-This species was first reported from the Mulga, Grizzly Bear, and Vanesti Tongues of the Belly River Formation in Alberta, Canada (Nauss, 1947, p. 339). It has since been tentatively identified from beds of Coniacian and Santonian age in Alberta (Wall, 1960, p. 20) and has been identified from the Seabee and Schrader Bluff Formations in Alaska (Tappan, 1962, p. 134-135).

Specimens which are here included in Haplophragmoides rota Nauss occur from 11 feet above the base of the Virgin Creek Member to 66 feet above the base of the Fox Hills Sandstone.

Material.-More than 1,000 specimens were found.

\begin{tabular}{|c|c|c|c|}
\hline \multirow{5}{*}{$\begin{array}{c}\text { Locality } \\
\end{array}$} & Sample & Locality & Sample \\
\hline & 1?-RR & $20 \ldots$ & $24-\mathrm{VR}$ \\
\hline & $3-V R$ & $27 \ldots$ & $10-V R$ \\
\hline & $5 ?-\mathrm{R}$ & $27 \mathrm{~A}_{\ldots} \ldots$ & 7-RR \\
\hline & 9?-R & & $9 ?-\mathrm{RC}$ \\
\hline \multirow[t]{8}{*}{3} & $1-\mathrm{C}$ & & $11 ?-\mathrm{R}$ \\
\hline & $3 ?-\mathrm{RC}$ & & $17 ?-\mathrm{RR}$ \\
\hline & $5 ?-\mathrm{RC}$ & & $19-X$ \\
\hline & $7 ?-\mathrm{R}$ & & $21-\mathrm{RR}$ \\
\hline & $9 ?-\mathrm{RC}$ & & $23-\mathrm{S}$ \\
\hline & $11 ?-\mathrm{RC}$ & $31 \ldots \ldots$ & $1-R$ \\
\hline & 18-RC & & $3-\mathrm{RC}$ \\
\hline & $22-\mathrm{R}$ & & 5-RR \\
\hline - & $9-\mathrm{R}$ & & $7-S$ \\
\hline & $17 ?-\mathrm{S}$ & & $9-\mathrm{R}$ \\
\hline & $19-X$ & & $11-S$ \\
\hline & $27-C$ & & $12-\mathrm{VR}$ \\
\hline & $29 ?-\mathrm{C}$ & & $14 ?-\mathrm{S}$ \\
\hline & $30 ?-X$ & & 17-VR \\
\hline 13 & $33 ?-\mathrm{S}$ & & $20-\mathrm{VR}$ \\
\hline
\end{tabular}

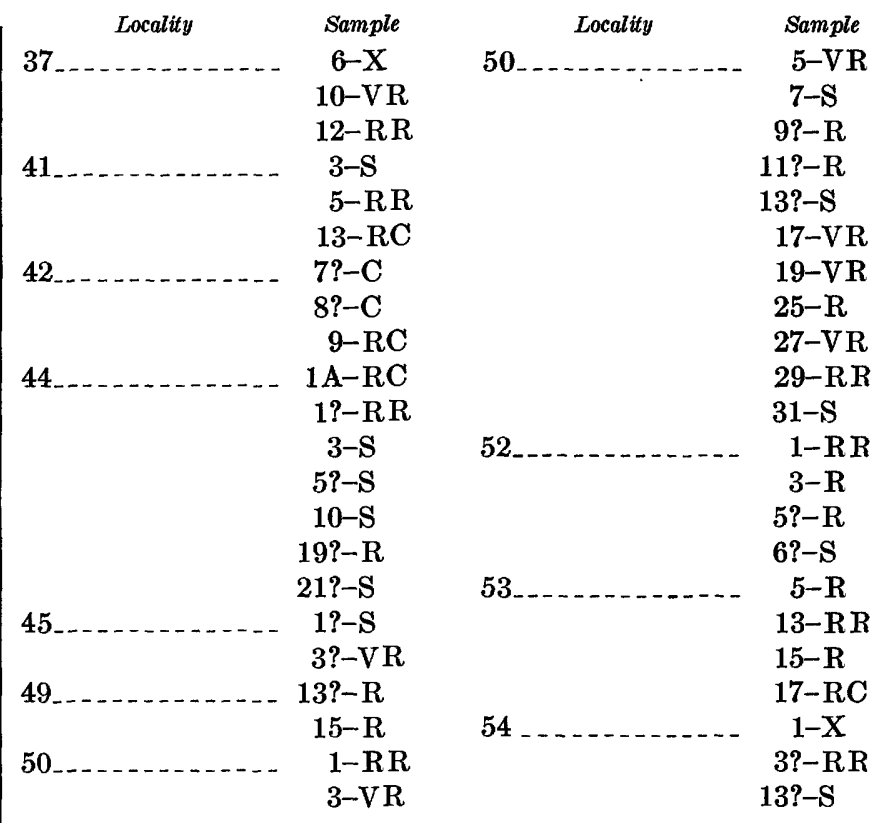

Haplophragmoides bonanzaensis Stelck and Wall

Plate 4, figures $6 a, b$

Haplophragmoides bonanzaensis Stelck and Wall, 1954, Research Council Alberta Rept. 68, p. 24, pl. 2, fig. 10.

Test planispiral, completely involute, biumbilicat?; periphery fairly broad, well rounded, slightly lobulats; umbilici open, shallow, small; chambers large, distinct, slightly inflated, five to seven in last-formed whorl, usually six; sutures distinct, depressed, straight, radial, occasionally oblique; wall smoothly finished, noncalcareous, with a rather high proportion of cement enclosing fine- to medium-grained silt particles; color usually milky white but ranges to rusty orange; aperture a very low interiomarginal equatorial silt. Dimensions of average-sized specimens: maximum diameter, $0.2 \mathrm{~mm}$ to $0.25 \mathrm{~mm}$; minimum diameter, about $0.2 \mathrm{~mm}$; thickness, about $0.15 \mathrm{~mm}$.

Remarks.-The apertures of most specimens are poorly defined or are not visible at all, but on some specimens the apertural area is clear and undistorted, and the aperture is a low-arched interiomarginal slit. The specimens compare well with hypotypes of $H$ aplophragmoides bonanzaensis from the Upper Cretaceons of Alaska (Tappan, 1962, p. 134) in terms of siz?, chamber shape, and chamber number, although preservation is quite different.

Specimens of this species are commonly distorted in various planes, as are the specimens of $H$. rota Nauss with which they are commonly associated. $H$. bonanzaensis, as differentiated from $H$. rota in this study, is generally smaller, has a smoother and less arenaceors 
wall, and has fewer chambers in the final whorl. In other respects these species are quite similar, and they may be variants of a single species.

Occurrence.-Haplophragmoides bonanzaensis Stelck and Wall was first reported from the Kaskapau Formation of Turonian age in Alberta and British Columbia (Stelck and Wall, 1954, p. 24). It has since been reported from the Seabee and Schrader Bluff Formations of Turonian to Campanian age in Alaska (Tappan, 1962, p. 134).

This species occurs from 25 feet above the base of the Virgin Creek Member to 24 feet above the base of the Fox Hills Sandstone. It becomes a dominant element in the fauna only in the upper part of the sequence where it increases in number and where its relative importance is greatly increased because of reduction in size of the fauna as a whole.

Material.-100 to 200 specimens were found.

\begin{tabular}{|c|c|c|c|}
\hline Locality & Sample & Locality & Sample \\
\hline $1 \ldots \ldots$ & $5-\mathrm{R}$ & $42 \ldots \ldots$ & $9-\mathrm{R}$ \\
\hline \multirow[t]{4}{*}{$3 \ldots$} & $11-\mathrm{R}$ & 44 & $19-\mathrm{S}$ \\
\hline & $14 ?-\mathrm{R}$ & $49 \ldots \ldots$ & $15-\mathrm{R}$ \\
\hline & $22-S$ & & $17-\mathrm{RC}$ \\
\hline & $23 ?-\mathrm{X}$ & & $19-R R$ \\
\hline $7 \ldots \ldots \ldots$ & $7 ?-\mathrm{S}$ & 50 & $1-V R$ \\
\hline $20 \ldots \ldots$ & $24-V R$ & & $3-V R$ \\
\hline \multirow[t]{3}{*}{$27 \mathrm{~A}_{\ldots} \ldots \ldots$} & 6-R & $52 \ldots$ & $1-R R$ \\
\hline & 7-RR & & $3-\mathrm{R}$ \\
\hline & $21-\mathrm{RR}$ & & $5-\mathrm{R}$ \\
\hline \multirow[t]{4}{*}{$31 \ldots \ldots$} & $1-\mathrm{R}$ & $53 \ldots$ & $3-X$ \\
\hline & $7-\mathrm{VR}$ & & 9-RR \\
\hline & $9-\mathrm{VR}$ & & $11-\mathrm{C}$ \\
\hline & $14-V R$ & & $13-\mathrm{RC}$ \\
\hline $36 \ldots \ldots$ & $4-R$ & & $15-\mathrm{R}$ \\
\hline $41 \ldots \ldots \ldots$ & $1-R$ & 54 & $5-\mathrm{R}$ \\
\hline
\end{tabular}

Haplophragmoides sp.

Many specimens of Haplophragmoides were too poorly preserved to permit species identification. The localities and samples from which these specimens came are env elated below.

\begin{tabular}{|c|c|c|c|}
\hline Locality & Sample & Locality & Sample \\
\hline$\ldots \ldots$ & $7-V R$ & $36 \ldots$ & $3-S$ \\
\hline 5 & $4-8$ & & $5-\mathrm{VR}$ \\
\hline $13 \ldots \ldots$ & $16-V R$ & $42 \ldots$ & $10-\mathrm{C}$ \\
\hline & $35-\mathrm{S}$ & 49 & $1-\mathrm{S}$ \\
\hline $20_{\ldots} \ldots \ldots$ & $17-\mathrm{VR}$ & & $3-\mathrm{S}$ \\
\hline $27 \ldots \ldots \ldots$ & $9-\mathrm{VR}$ & & $7-X$ \\
\hline $27 \mathrm{~A}_{\ldots} \ldots \ldots \ldots$ & $3-x$ & & $9-\mathrm{VR}$ \\
\hline & $5-\mathrm{S}$ & $52 \ldots \ldots \ldots$ & $7-S$ \\
\hline & $15-\mathrm{X}$ & & \\
\hline
\end{tabular}

\section{Family TEXTULARIIDAE}

\section{Genus SPIROPLECTAMMINA Cushman, 1§27}

Spiroplectammina laevis (Roemer) cretosa Cushman

Plate 4, figures 7a-c

Spiroplectammina laevis (Roemer) var. cretosa, Cushman, 1932, Cushman Lab. Foram. Research Contr., v. 8, pt. 4, p. 87, pl. 11, figs. 3a, b.

Test biserial, elongate, about $11 / 2$ times as long as broad, compressed; tapers rather rapidly to a sharply rounded initial end, greatest breadth at tha apertural end, thickest at the apertual end through tho middle of the test; periphery subacute to acute, lobulate, in some specimens dentate; apertural end nearly flat, widest at the center and tapers rapidly to the acute peripheries, perpendicular to the vertical axis at the midline, becomes oblique toward the peripheries, apertural face very low and rounded; early coiled part obscure, small, involves only the first few chambers, rapidly becomes biserial; chambers distinct, not inflated, long, low, slightly overlapping; sutures flush or slightly raised, limbate, gently convex upward, oblique to the axis of elongation; wall finely arenaceous, with a rariable but generally high proportion of calcareous cement, not usually collapsed; aperture an arched, centrally located, interiomarginal opening extending for one-third to onefourth the thickness of the test, slightly recessed between the lateral areas of the apertural face. Dimensions of average-size specimens: length, 0.25 to $0.35 \mathrm{~mm}$; breadth, about $0.25 \mathrm{~mm}$; thickness, 0.1 to 0.15 $\mathrm{mm}$.

Remarks.-Specimens of this subspecie? are often preserved as pyritic internal molds. They are commonly associated with a predominantly calcareous-perforate suite of Foraminifera. Some specimens, referred to this subspecies with question, have noncalcareous walls but are otherwise very similar to the more conmon specimens with calcareous walls. Noncalcareous specimens have not been found in samples containing calcareous specimens. Diagenetic replacement of calcite by silica may account for this difference, or it may bo due to the substitution of silica by calcite as a cementing agent by the living animal.

Spiroplectammina nuttalli Lalicker is in general very similar to $S$. laevis cretosa but differs in having a smoother periphery, in being somewhat thicker, and in lacking raised, strongly limbate sutures. S. knebeli LeRoy is quite a bit wider than the Pierre species, whereas S. Knebeli var. longa Said and Kenawy is more closely 
similar but differs in being slightly thicker and in having a smoother surface texture. S. esnaensis LeRoy has a different wall texture and slightly higher chambers. The Pierre specimens differ from the type specimens of $S$. laevis cretosa only in having slightly higher chambers. Cushman did not state that the wall of this subspecies is calcareous, but a plesiotype designated by him was tested with dilute hydrochloric acid and was found to be very calcareous.

Occurrence.-To my knowledge, Spiroplectammina laevis cretosa has not been reported previously from deposits in the western interior of the United States or from Canada. Cushman (1946, p. 28) recorded its occurrence in beds of Austin and Taylor ages in the Gulf Coastal Plain. It was reported from the Mt. Laurel and Navesink Formations in New Jersey (Jennings, 1936, p. 12) and from the Hammond well near Salisbury, Md. (Cushman, 1948a, p. 245). It was also reported from the UTper Cretaceous of France, Japan, Israel, Ireland, Germany, and Western Australia.

In the upper part of the Pierre Shale this subspecies occurs from 115 feet below the lower key bentonite to 81 feet above the upper key bentonite.

Material.-More than 1,000 specimens were found.

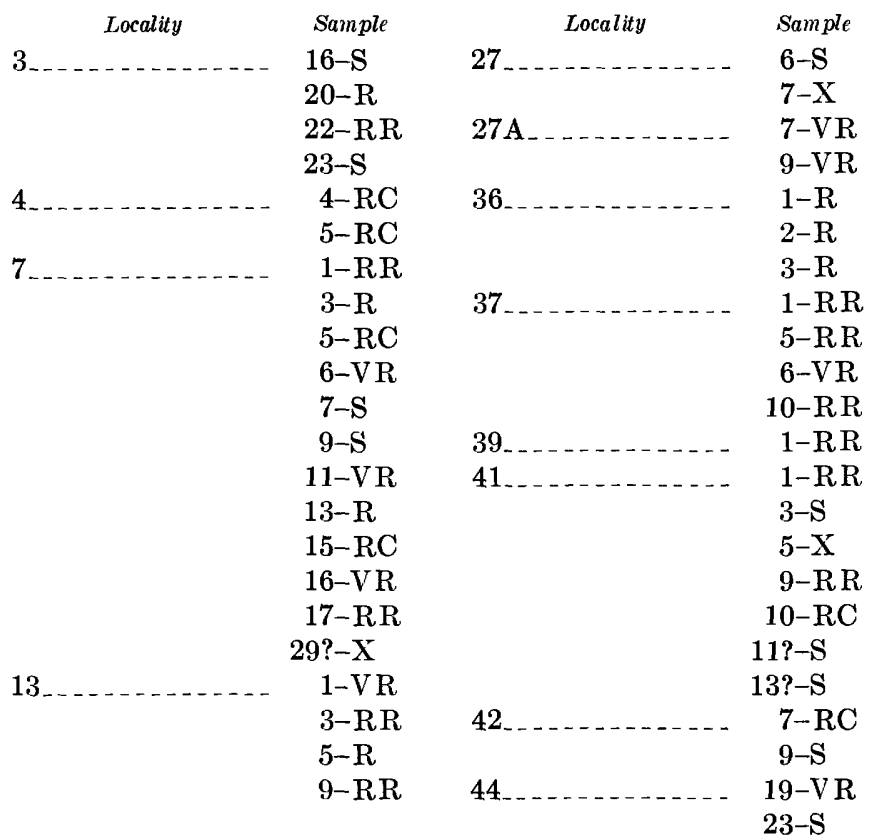

Spiroplectammina mordenensis Wickenden

Plate 4, figures 8a-d

spiroplectammina mordenensis Wickenden, 1932, Royal Soc. Canada Trans. 3d ser., v. 26, sec. 4, p. \$6, pl. 1, fig. 4.

Test initially planispiral, later becoming biserial, elongate in larger specimens, compressed; $11 / 4$ to 2 times as long as broad, broadest and thickest at apertural end except in some of the longest specimens; lateral periph- eries usually irregular in outline, sometimes smooth, acute to subacute; apertural end rhomboidal in outline, slightly convex, composed of the upper surfaces of the last and penultimate chambers which meet at an acute angle in the midline of the test; planispiral part composed of four to seven chambers in addition to the proloculus, diameter of the initial end dependent upon the size of the chambers composing the coil; specimens with a coiled part of large diameter increase less rapidly in breadth than specimens with a coiled part of small diameter; size of chambers in the coil apparently rot directly related to the size of the proloculus; biserial part composing most of the test in all but the smallest specimens, usually composed of four or five pairs of chambers, but some specimens have as many as seven pairs; chambers oblique to axis of elongation, usually not inflated, two to three times broader than high, regularly increase in size as added, slightly overlapping; in all longer specimens the final few pairs of chambers become nearly as high as broad; sutures usually flush with the surface, indistinct, occasionally slightly depressed, slightly if at all limbate, oblique to the axis of elongation, straight or slightly convex toward the apertural end; wall arenaceous, composed of either calcareous or noncalcareous particles; particle size ranges from relatively coarse grained to fine grained, amount of cement variable, finer grained particles and more cement characteristic of calcareous specimens; aperture a lowarched interiomarginal opening at the midline of the test, located in a slight invagination at the base of the low rounded apertural face.

Remarks.-The breadths, lengths, and thicknesses of 13 specimens were measured. The specimens rangod from $0.23 \mathrm{~mm}$ to $0.47 \mathrm{~mm}$ in length. The length-tobreadth ratio varied from $1.3: 1$ to $1.9: 1$; the length-tothickness ratio varied from $2.2: 1$ to $4.7: 1$; and the breadth-to-thickness ratio varied from $1.7: 1$ to $2.5: 1$. Only one definitely megalospheric specimen was found. Its length-to-breadth ratio was slightly higher $(2.0: 1)$ than the highest value of this ratio for microspheric specimens $(1.9: 1)$, but the other ratios for this specimon were within the ranges shown by the microspheric sperimens.

As can be inferred from the variations described for the measured dimensions, amount and coarseness of arenaceous material, calcareous and noncalcareous nature of the wall, chamber shape, and initial coiled part, the interpretation of the species encompasses specimens different from each other in a number of ways. All these variations are either present in single specimens or cre gradational within suites of specimens, except that the wall is either calcareous or noncalcareous. Features that unite these specimens are the fairly uniform number of 
FORAMINIFERA, STRATIGRAPHY, PIERRE SHALE, FOX HILLS SANDSTONE, S. DAK.

chambers in the coiled part and the generally small number, obliquity, and shape of chambers in the biserial part.

To my knowledge, the only previously described species of Spiroplectammina that includes at least some of the specimens found in the Pierre samples is $S$. mordenensis Wickenden. These similar specimens seem to be related to specimens showing the described variations through several suites of morphologically intermediate specimens. Some of the Pierre specimens resemble $S$. gaultana Lalicker, and others resemble S. gryzbowskii Frizzell, but none is considered similar enough to be placed in these species.

Occurrence.-Spiroplectammina mordenensis Wickenden was originally described from the Upper Cretaceous Morden beds of Manitoba, Canada (Wickenden, 1932a, p. 86). It has since been reported from the Sentinel Hill and Barrow Trail Members of the Schrader Bluff Formation in Alaska (Tappan, 1962, p. 140) and from the Tuluga Member of the Schrader Bluff Formation (Tappan, 1951, p. 5).

The Pierre specimens are found in small numbers in samples sporadically distributed from 107 feet below the lower key bentonite to within 20 feet of the base of the Fox Hills Sandstone.

Material.-Fewer than 150 specimens were found, many of which were not well preserved.

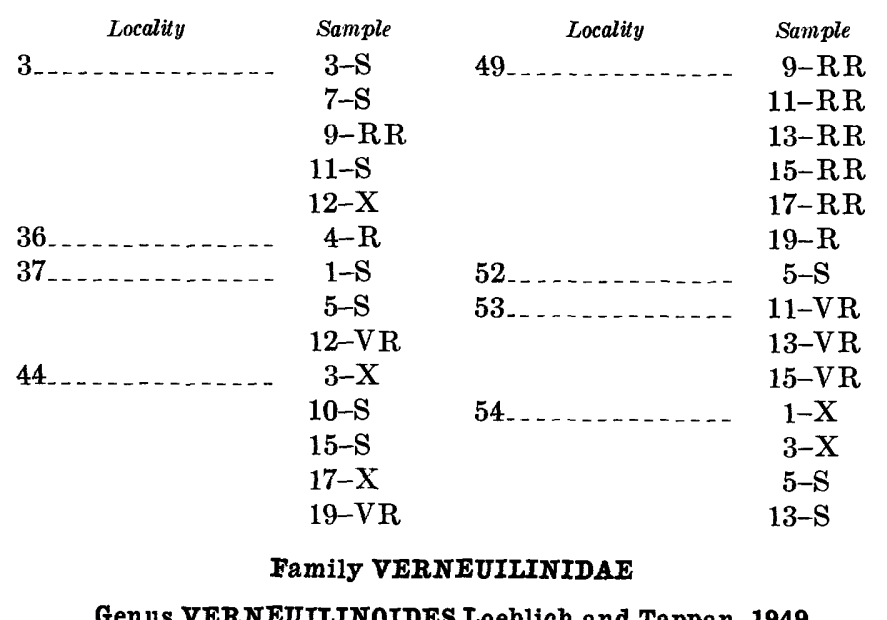

Verneuilinoides cf. V. perplexus (Loeblich)

Plate 1, figures 1a, b

Verneuilina perplexa Loeblich, 1946, Jour. Paleontology, v. 20, no. 2, p. 138, pl. 22, figs. 14-16.

Terneuilinoides perplexus (Loeblich). Loeblich and Tappan, 1949, Washington Acad. Sci. Jour., v. 39, no. 3, p. 91.

Test elongate, slender to rather rapidly flaring with early part of some specimens in a definite slightly twisted triserial arrangement followed by a more bulimine arrangement of later chambers; other specimens apparently with all chambers in a strongly twisted or bulimine arrangement; slightly twisted triserial part, when present, composed of as many as four whorls; chambers slightly to moderately inflated, sul rylobular, rather closely appressed, slightly to moderately overlapping, generally increase regularly and moderately in size as added but in some specimens show an unusual increase in size near the apertural end of the test, often at the start of bulimine chamber arrangement; sutures in early part indistinct, flush or slightly deprassed, distinct and depressed between later and larger chambers; wall arenaceous, composed of numerous closely fitted quartz grains held by a rather small amount of cement; surface moderately rough textured, noncr.lcareous; aperture a high-arched opening at the base of the apertural face, set in a large indentation of the apertural face, not well preserved on most specimens. Dimensions of average-sized specimens: length, about $0.4 \mathrm{~mm}$; breadth, about $0.15 \mathrm{~mm}$.

Remarks.-Most of the Pierre specimens are distorted, but several of the better preserved specimens closely resemble the holotype and paratypes of Verneuilinoides perplexus. Distorted specimens correspond very well with distorted paratypes (Cushman colln. 44122).

Despite the similarity of some of the Pierre specimens to the type specimens of Verneuilinoides perplexus, assignment to this species is not positive because of the bulimine arrangement of chambers in at leas' a part of nearly all specimens. In addition, the Pierre specimens are more coarsely arenaceous and contain less cement than the types.

Occurrence.-Verneuilinoides perplexus (Loeblich) was originally described from the Upper Cretaceous Pepper Shale (Pepper Shale Member of Woolbine Formation) of Texas (Loeblich, 1946, p. 138) and has since been reported from shale of Cenomanian ag. (Dunveganoceras zone) in Alberta, Canada (Stelck and Wall, 1955$, p. 60$)$.

This species occurs from 70 feet above the upper key bentonite to 24 feet above the base of the Fox Hills Sandstone in the Moreau River sections and from 58 feet above the upper key bentonite to just below the base of the Fox Hills in the Grand River sections.

Material.-100 to 200 specimens were found, most of which were distorted.

\begin{tabular}{|c|c|c|c|}
\hline \multirow{3}{*}{$27 \mathrm{~A}_{-} \quad$ Locality } & Sample & Locality & Sample \\
\hline & $7-X$ & 52 & $1-R R$ \\
\hline & $21-\mathrm{S}$ & & $3-\mathrm{RR}$ \\
\hline \multirow[t]{4}{*}{$31 \ldots$} & $1-V R$ & & $5-R R$ \\
\hline & $3-V R$ & & $6-V R$ \\
\hline & $9 ?-\mathrm{S}$ & $53 \ldots$ & $7-\mathrm{S}$ \\
\hline & $20-X$ & & $9-S$ \\
\hline \multirow{5}{*}{50} & $17 ?-\mathrm{R}$ & & $11-R R$ \\
\hline & $1-R R$ & & $13-\mathrm{RR}$ \\
\hline & $3-\mathrm{R}$ & & $15-\mathrm{RR}$ \\
\hline & $5-R$ & & $17-R R$ \\
\hline & $7-S$ & & \\
\hline
\end{tabular}


Genus GAUDRYINA d'Orbigny, 1839, emend. Bowen, 1955

Subgenus GAUDRYINA Cushman 1937, emend. Bowen, 1955

\section{Gaudryina (Gaudryina) watersi (Cushman)}

Plate 4, figures 9a-c

Plectina watersi Cushman, 1933, Cushman Lab. Foram. Research Contr., v. 9, pt. 3, p. 57, pl. 7, figs. 1a-d.

Test elongate, early triserial part prominent, later becomes biserial; triserial part tapers, broadly triangular with well-rounded edges when viewed from initial end, composes at least one-fourth of the length of even the largest specimens, broader than biserial part in side view; biserial part tapers slightly in side and front views, slightly twisted in some specimens, consists of three and sometimes four pairs of chambers; chambers indistinct in early part of triserial arrangement, later fairly distinct and slightly inflated, distinct and moderately inflated in biserial part; sutures become progressively more depressed with addition of chambers, moderately oblique in biserial portion; wall finely to moderately coarsely arenaceous, about 20 percent cement, cement soluble in dilute $\mathrm{MCl}$; aperture in the triserial part a simple high-arched opening at the basal margin of the last-formed chamber at the center of the upper surface; aperture in the biserial part somewhat recessed into the higher apertural face and becomes more recessed as chambers are added, in the largest specimens almost completely isolated in the apertural face, with only a small part of the periphery being formed by the upper surface of the penultimate chamber. Dimensions of average-sized specimens : length 0.55 to $0.6 \mathrm{~mm}$; breadth across biserial chambers about 0.25 $\mathrm{mm}$.

Remarks.-The emendation of the genus Gaudryina by Bowen (1955, p. 363-364) was made for the purpose of including in this genus a group of fossils which, up to that time, had been placed in separate but similar genera. The genus Plectina Marsson, 1878, was one of those placed in synonymy. In order to test Bowen's idea of the artificiality of the use of number of chambers in the initial whorl as a diagnostic character, I etched a paratype of $P$. watersi and found that the initial whorl consisted of three chambers surrounding a central proloculus. Bowen's arguments are supported by this finding, and I feel that he is correct in placing Plectina in synonymy with Gaudryina.

The early arrangement of chambers in the Pierre specimens is definitely triserial, as determined by etching a number of specimens. In addition, the prominence of the triserial part and its rounded angles are very similar to these features in the type specimens of $P$. watersi. However, the biserial chambers, in the Pierre specimens show less tendency toward the uniserial con- dition than do the types. The aperture never become entirely isolated in the apertural face in the Pierr? specimens, although in several it is terminal or nearly so and maintains contact with the penultimate chamber: through only a very small part of the apertural periphery. Unfigured specimens from the Nacatoch Sand (Cushman Collin. 28062) and Selma Group (Cushman collin. 28059) identified as $P$. watersi also do not have the aperture isolated in the apertural face.

Because of the close approach of the aperture to isclation in the apertural face and the very close similarit: in plan, shape, size, and texture of the test to that of $G$. watersi (Cushman), the Pierre specimens are placed in this species. The generic name Plectina is considered to be a junior synonym for Gaudryina, following th? emendation of Bowen (1955, p. 363-364).

An interesting feature, also noted for the Pierre specimens of Bathysiphon brosgei Tappan? and G. boveri Mello, is the larger size of arenaceous material composing the tests of specimens of all three species in samples 14,16 , and 18 of section 3 .

Occurrence.-This species has been reported from beds of Navarro age in the Gulf Coastal Plain by Cuslman $(1946$, p. 47$)$. It has also been reported from the Upper Cretaceous Vidoño Shale Member of the Santa Anita Formation of northeastern Venezuela and from beds of Senonian, Maestrichtian, and Danian ages in northeastern Bulgaria.

Gaudryina watersi occurs in the upper part of the Pierre Shale from 80 feet above the upper key bentonite to 144 feet below the lower key bentonite.

Material. -500 to 1,000 specimens were found.

\begin{tabular}{|c|c|c|c|}
\hline \multirow{5}{*}{ Locality } & Sample & Locality & Sample \\
\hline & $11-V R$ & $27 \mathrm{~A}_{\ldots} \ldots$ & $2-\mathrm{VF}$ \\
\hline & $14-\mathrm{RC}$ & & $3-\mathrm{VF}$ \\
\hline & $16-R R$ & & $9 ?-\mathrm{S}$ \\
\hline & $18-\mathrm{RR}$ & 36 & $2-S$ \\
\hline \multirow{4}{*}{$\begin{array}{l}5_{1} \\
7_{2}\end{array}$} & $8-V R$ & & $4-V F$ \\
\hline & $1-X$ & & $5-\mathrm{S}$ \\
\hline & $30-\mathrm{RC}$ & $37_{1}$ & $5-\mathrm{S}$ \\
\hline & $32-\mathrm{S}$ & 44 & $23-\mathrm{S}$ \\
\hline \multirow{2}{*}{13} & $40-X$ & 49 & $5-\mathrm{S}$ \\
\hline & $41-X$ & & $9-\mathrm{S}$ \\
\hline $20 \ldots$ & $17-\mathrm{VR}$ & & $15-\mathrm{R}$ \\
\hline \multirow{2}{*}{$27 \ldots$} & $6-\mathrm{S}$ & & $19 ?-X$ \\
\hline & $7-S$ & 54 & $1-X$ \\
\hline
\end{tabular}

Gaudryina boweni Mello, new name

Plate 4, figures 10a, b

Dorothia stephensoni Cushman, 1936, Cushman Lab. Foram. Research, Spec. Pub. 6, p. 28, pl. 4, fig. 15 (not Gaudryira stephensoni Cushman, 1928).

Test elongate, early part in a low trochoid spire, three to four chambers per whorl; later part biserial, slight $]$ twisted, nearly circular viewed from initial end, slight ${ }^{\top} y$ 
to moderately compressed viewed from apertural end; sides moderately taper in front view, nearly parallel in edge view, greatest breadth at apertural end; chambers in trochoid part overlapping, indistinct; in later biserial part, chambers slightly inflated, distinct; sutures flush and indistinct in trochoid part, slightly depressed and distinct between later inflated chambers, perpendicular or nearly so to the axis of elongation; wall finely to moderately finely arenaceous, rather smoothly finished, reacts with dilute $\mathrm{HCl}$, white or gray; aperture a narrow elongate slit at the center of the base of the final chamber surrounded by a slight thickening; base of aperture formed by top of preceding chamber. Dimensions of average-sized specimens: length, about 0.45 $\mathrm{mm}$; breadth of biserial part about $0.25 \mathrm{~mm}$; thickness of biserial part about $0.15 \mathrm{~mm}$.

Remarks.-In the Pierre specimens the low trochoid part is generally very short and is always several times shorter than the biserial portion. The amount and coarseness of arenaceous material is rather variable, but the most coarsely arenaceous specimens were obtained from section 3, samples 14,16 and 18 , the same stratigraphic interval that yielded the most coarsely arenaceous specimens of Bathysiphon brosgei Tappan? and Gaudryina watersi (Cushman). The surface texture and appearance of these three species are very similar in this interval.

The validity of the genus Dorothia is discussed by Bowen (1955, p. 362-363), who concluded that this genus should be considered a junior synonym of the genus Gaudryina. I find Bowen's arguments to be convincing and have here adopted his recommendation by placing Dorothia stephensoni Cushman in Gaudryina. The new name $G$. bowen $i$ is proposed because the specific name stephensoni is preoccupied in the genus Gaudryina.

Occurrence.-This species has been reported as Dorothia stephensoni Cushman from beds of Austin, Taylor, and Navarro ages in Arkansas, Alabama, and Texas (Cushman, 1946, p. 45). It has also been reported from the Senonian and Maestrichtian of Bulgaria.

In the upper part of the Pierre Shale, the species occurs from the base of the section to 64 feet above the upper key bentonite in the Grand River sequence and from 139 to 25 feet below the lower key bentonite in the Moreau River sections.

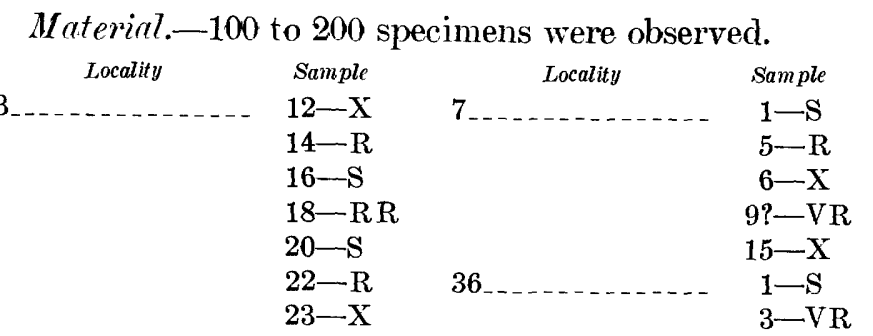

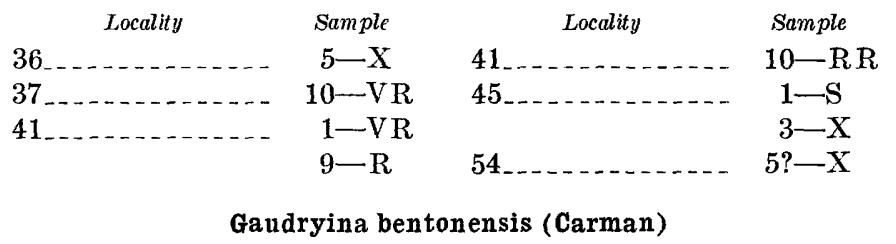

Plate 4, figures 1.1a, b

Npiroplectammina bentonensis Carman, 1929, Jour. $\mathbf{P} \uparrow$ leontology. v. 3, no. 3, p. 311, pl. 34, figs. 8,9 .

Gaudryina bentonensis (Carman). Cushman, 1932, Cushman Lab. Foram. Research Contr., v. 8, pt. 4, p. 96.

Cushman, 1937, Cushman Lab. Foram. Research Spec. Pub. 7, p. 42, pl. 6 , fig. 22 .

Cushman and Deaderick, 1942, Cushman Lab. Foram. Research Contr., v. 18, pt. 3, p. 52, pl. 9, figs. $12,13$.

Test elongate, straight, slightly twisted, usually distorted, earliest part obscure but probably triserial, followed by triserial part of variable length and then by a biserial part also of variable length but composing at least half of the longest specimens; chambers in triserial part slightly inflated, spheroidal, with shortest axis vertical and overlapping, similar in biserial part except more inflated and less overlapping; chambers increase in size fairly slowly in triserial part, very slc wly or not at all in biserial part so that the sides of the longer specimens are parallel or nearly so; wall ccmposed of silt grains of medium size relative to test size and embedded in a moderate amount of noncalareo's cement; sutures obscure in early part of triserial stage, become more distinct and depressed in later part of triserial stage and in biserial stage as chambers berome more inflated, perpendicular, or nearly so, to the axis of elongation; aperture obscured by crushing in all available specimens, but in the biserial stage apparently a simple opening in the midline of the test in the apertural face of the final chamber at or near the suture line separating this chamber from the preceding one. Dimensions of average-sized specimens : length, about $0.7 \mathrm{~mm}$; breadth, about $0.15 \mathrm{~mm}$.

Remarks.-In some specimens there is a tendency towards separation of the final few chambers from those immediately below, as evidenced by increasing incision of the sutures and corresponding decrease in chamber overlap. In a few samples containing Gaudryina bentonensis, several partial specimen of a large uniserial form composed of three or four chambers, with wall texture similar to $G$. bentonensis and with a protruding terminal aperture, were observed. These may represent a further development of $G$. bentonensis beyond what can be observed in complete specimens. However, a uniserial stage has not been found attached to any biserial specimen.

The Pierre specimens are very similar to the holotype and paratypes of Spiroplectummina bentonensis Car- 
man and to the plesiotypes figured in the papers cited in the synonymy. They also correspond quite well to nearly all the remaining specimens of $G$. bentonensis in the U.S. National Museum collections, when allowances are made for the distortion of the specimens.

Occurrence.-The species has been reported from the Upper Cretaceous of Trinidad, British West Indies (Cushman and Renz, 1946, p. 21; 1947, p. 38), from rocks of Austin, Taylor, and early Late Cretaceous age in Texas and Arkansas (Cushman, 1946, p. 33), from the Benton Shale and Niobrara Chalk of Wyoming (Carman, 1929, p. 311), from the lower shale member of the Niobrara Formation in Wyoming (Shaw, 1953), and from the Carlile and Cody Formations in South Dakota and Wyoming (Fox, 1954, p. 105, 107, 109).

This species is found from 5 feet above the lower key bentonite to the base of the Virgin Creek Member of the Pierre Shale.

Material.-About 170 specimens are found.

$\begin{array}{clcc}\text { Locality } & \text { Sample } & \text { Locality } & \text { Sample } \\ 1-\mathrm{RR} & 3 \ldots & 11-\mathrm{R} \\ & 3-\mathrm{R} & & 12-\mathrm{R} \\ & 5-\mathrm{R} & & 18-\mathrm{R} \\ & 7-\mathrm{RR} & & 22-\mathrm{S} \\ & 9-\mathrm{RC} & & 23-\mathrm{RR} \\ & 1-\mathrm{RC} & 37 \ldots \ldots & 3-\mathrm{S} \\ & 3-\mathrm{RR} & 42 \ldots & \\ & 5-\mathrm{R} & & 8-\mathrm{R} \\ & 9-\mathrm{RR} & 44 \ldots & 9-\mathrm{RC} \\ & & & 1 \mathrm{~A}-\mathrm{R}\end{array}$

Genus PSEUdoclavUlina Cushman, 1936

Pseudoclavulina? meidamos Mello, n. sp.

Plate 1, figures 2a-c ; plate 5, figures 1a-d

Test agglutinated, elongate, straight or slightly irregular; earliest part composed of the proloculus and about eight chambers arranged three to a whorl, forms a low relatively broad trochoid spire, becomes uniserial above the spire with no intervening biserial stage; chambers in trochoid part globular, closely appressed, increase rather rapidly in size as added, except much less rapidly for the final three or four chambers, indistinct when dry, fairly distinct when moistened; uniserial part composed of one to five globular to spheroidal chambers, usually three or four, each of which is slightly larger than its predecessor, slightly to moderately overlapping, quite distinct and slightly inflated; sutures indistinct in trochoid part, distinct and slightly depressed in uniserial part, oblique in the earliest uniserial part of some specimens, later more nearly horizontal; wall rather thick, smooth for agglutinated specimens, composed predominantly of small calcite grains with occasional quartz grains, ce- ment probably calcareous; aperture terminal, elongate, narrow, straight to very slightly curved, upper surface of the final chamber is at different levels on either side of the aperture, the higher side has an abrupt truncation forming one side of the aperture, and a distinct flap rises from the lower surface to the level of the higher surface to form the other side of the aperture; the aperture itself is the elongate narrow slit between the top of this flap and the edge of the higher surface; most specimens have a small lip about the aperture, but several have larger lips which give the aperture a protruding aspect; no internal tube is present between apertures. Dimensions of average-sized specimens: length, about $0.3 \mathrm{~mm}$; breadth, about $0.1 \mathrm{~mm}$.

Remarks.-The distinguishing characteristics of this species are the short, broad, roughly triserial trochoid stage in which the later chambers increase markedly in size as added, the following uniserial stage composed of inflated globular to spheroidal chambers, the finegrained calcareous wall, and the narrow elongate aperture.

The genus Pseudoclavulina has a triserial arrang?ment of the early chambers followed by a uniserial s?ries of chambers, and in these respects the new species resembles this genus, but no species of Pseudoclavulina has an aperture similar to that of the new species. A similar aperture is present in Martinottiella paleocenica Cushman, but this genus has four or more chambers per whorl in the early trochoid part whereas the new species has only three. The new species is tentatively placed in the genus $P$ seudoclavulina until further study of its variability and phylogeny becomes possible.

Examination of crushed specimens under the petrographic microscope revealed that the walls are composed of very small calcite grains oriented randomly. The apparently poreless nature of the wall and the presence of what appear to be silt-sized particles embedded in the wall, as determined under $\times 216$ magnificaticn, indicate that the wall is agglutinated. There is no tooth connected with the aperture, and there is no extension of any kind from one aperture to the next.

Occurrence.-This species occurs from the level of the lower key bentonite to 47 feet below this level. Ore specimen, placed here with question because of porr preservation, occurs 94 feet above the upper key bentonite. The holotype and paratypes of Pseudoclavulina? meidamos are from locality 41 , sample 1 . Holotype, USNM (U.S. National Museum) 642579; figured paratype, USNM 642580; unfigured paratypes, USNM $642581,6 \pm 2582$. 
Material.-Fewer than 50 specimens were found.

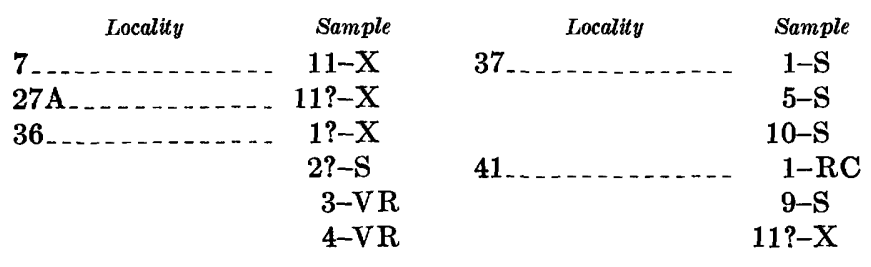

Genus CLAVtrIroIDEs Cushman, 1936

Clavulinoides trilaterus (Cushman)

Plate 1, figuress $3 a, b$

Clavulina trilatera Cushman, 1926, Am. Assoc. Petroleum Geologists Bull., no. 6, v. 10, p. 588, pl. 17, fig. 2.

Clavulinoides trilatera (Oushman). Cushman, 1937, Gushman Lab. Foram. Research Spec. Pub. 7, p. 121, pl. 16, figs. 12-18.

Clavulina trilatera Oushman var. concava Cushman, 1931, Jour. Paleontology, v. 5, no. 4, p. 302, pl. 34, figs. 12a, b.

Clavulinoides trilatera (Cushman) var. concava (Oushman). Cushman, 1937, Cushman Lab. Foram. Research Spec. Pub. 7, p. 121, pl. 16, figs. 19-25.

Test elongate, early triserial part rather rapidly tapers, consists of four or five whorls in which chambers increase rapidly in size as added, sides parallel in later uniserial part, triangular throughout, angles distinct, keeled; in the uniserial part chambers fairly distinct, overlap considerably, of rather uniform size and shape, increase in size slightly if at all as added; sutures fairly distinct, slightly depressed, oblique in triserial part and form a chevron pattern on each side, in uniserial part slightly convex upward, slightly oblique, become nearly horizontal in larger specimens; wall distinctly arenaceous, appears smoothly finished but in detail rather rough, composed of well-sorted small grains, percentage of cement variable but usually high, either cement or grains or both are calcareous; aperture in the triserial stage a simple small, rounded interioareal opening a slight distance above the junction of the final and penultimate chambers and near the point of junction of the final three chambers at about the center of the test, in the uniserial part the aperture is a small rounded to irregular opening at the apex of the chamber at about the center of the test that projects very slightly. Dimensions of a verage-sized specimens: length, about 0.9 $\mathrm{mm}$; breadth, about $0.45 \mathrm{~mm}$.

Remarks.-The type specimens of Clavulinoides trilatera var. concava (Cushman) differ from the types of $C$. trilaterus (Cushman) in having more acute angles and more concave sides, properties shared by the Pierre specimens. Varieties no longer have taxonomic status, according to the "International Code of Zoological Nomenclature" (Stoll and others, 1961) and the occurrence of var. concava in samples with $C$. trilaterus (Cushman, 1946, p. 38) suggests that it cann t be considered a valid biologic subspecies. Therefore the Pierre specimens and Cushman's var. concava are here placed in Clavulinoides trilaterus (Cushman) undifferentiated.

Occurrence.-Clavulinoides trilatera var. concava has been reported from beds of Taylor and Navarro ages in Tennessee, Alabama, Mississippi, Texas, and Arkansas by Cushman $(1946$, p. 38). It has also been reported from the Upper Cretaceous of Maryland (Cushman, 1948a, p. 246), from beds of Maestrichtian age in Egypt, and from the Cretaceous of northeastern Bulgaria.

In the upper part of the Pierre Shale this species occurs from 82 feet below the lower key bentonite to 17 feet above the upper key bentonite.

Material.-20 to 30 well-preserved specimens were found.

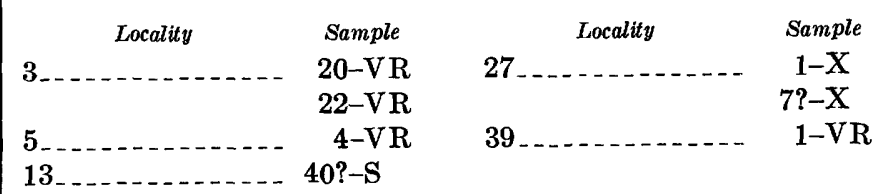

\section{Genus HETEROSTOMELLA Reuss, 1865}

Heterostomella americana Cushman

Plate 5, figures 2a-c

Heterostomella americana Cushman, 1936, Cushman Lab. Foram. Research Spec. Pub. 6, p. 24, pl. 3, fig. 20.

Remarks.-A single well-preserved microspheric specimen is assigned to Heterostomella americana. Its early triserial part is about one-third the ler gth of the test and is followed by a biserial part ornamanted with four or five longitudinal partially eroded ridges; the aperture is atop a very short neck. The specimen compares well with the holotype and paratypes of this species.

Occurrence.-Cushman (1946, p. 41-42) listed the species from beds of Taylor and Navarro ages in the Gulf Coastal plain but stated that "So far s.s seen, $H$. americana is confined to the Taylor marl and its equivalent of Texas and related areas, with the exception of a few specimens from the Navarro that may be identical." The species has also been reported from the Upper Cretaceous of Maryland (Cushman, 1948a, p. $247)$.

The single specimen from the upper part of the Pierre Shale was found 28 feet below the lower key bentonite. Material.-One specimen.

Locatity
41
$4 a m p l e$


Family SILICINIDAE

Genus SIIICOSIGMOIIINA Cushman and Church, 1929

Silicosigmoilina futabaensis Asano

Plate 5, figures 3a, b

Silicosigmoilina futabaensis Asano, 1950, Pacific Sci., v. 4, no. 2, p. 159 , pl. 1, figs. 6,7 .

Silicosigmoilina californica Cushman and Church. Applin, 1933, Jour. Paleontology, v. 7, no. 2, p. 219.

Test compressed, oval to nearly circular in equatorial outline, periphery subacute; chambers indistinct in early part, possibly planispirally arranged, later added in planes not quite $180^{\circ}$ apart; sutures flush or slightly depressed, indistinct; wall finely arenaceous, smooth to slightly grainy, generally flat white but in some specimens slightly vitreous; aperture the open end of the final chamber, irregular, somewhat produced and constricted, apparently without a tooth. Dimensions of average-sized specimens: length, 0.55 to $0.6 \mathrm{~mm}$; breadth, about $0.35 \mathrm{~mm}$; thickness, 0.05 to $0.1 \mathrm{~mm}$.

Remarks.-Some of the Pierre specimens closely resemble some of the paratypes of Silicosigmoilina californica Cushman and Church, but in general they are much more compressed than S. californica. The Pierre specimens seem to be better accommodated in $S$. futabaensis Asano, judging from the type description and figures (no comparative specimens were seen). S.futabaensis and S. californica are certainly closely related and may be variants of single species, although this has not been demonstrated yet.

Unfigured specimens on Cushman collection slides 28096 and 28097 labeled "Rzehakina epigona var. lata" also appear to belong in $S$. futabaensis. These specimens and the specimens from the upper part of the Pierre cannot be placed in the genus Rzehakina because of the nonplanispiral mode of addition of at least the later chambers.

A small group of specimens identified as S. catiformica Cushman and Church by Cushman and listed by Applin $(1933$, p. 219) from the Pierre Shale in South Dakota are like the Pierre specimens found in the present investigation and are here placed in $S$. futabaensis.

Occurrence.-Silicosigmoilina futabaensis was originally described from Senonian carbonaceous sandstone and shale at Yokouchi, Honshu, Japan. It has since been reported from Hokkaido, Japan (Fukuta, 1957 , p. 10; Yoshida, 1958, p. 259), and from beds of Coniacian-Santonian age near Redding, Shasta County, Calif. (Trujillo, 1960, p. 303).

This species is present in the upper part of the Pierre Shale 174 to 52 feet below the lower key bentonite in the Moreau River sections.
Material.-Fewer than 75 specimens were seen, man!" of which were at least somewhat distorted.

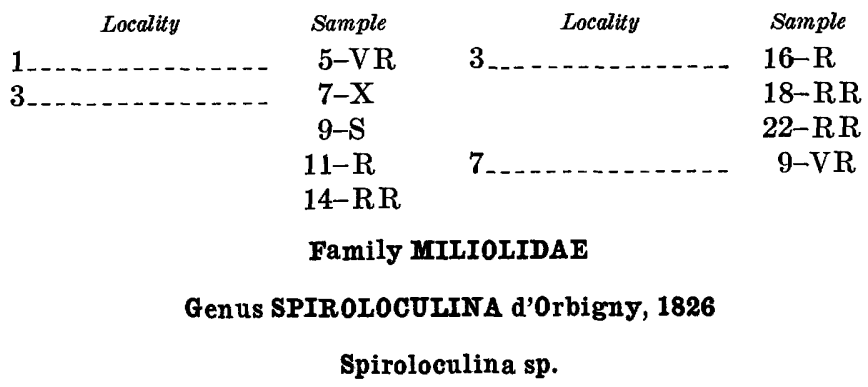

Remarks.-A single specimen referable to this genus was found. The test is very small, narrowly ovate, and flat and lacks an early quinqueloculine stage. The final chamber is broken, and apertural characters could not be observed. The specimen seems to be quite similar to specimens of Spiroloculina cretacea Reuss in the U.S. National Museum collections and may belong in thi : species. Dimensions: length, $0.2 \mathrm{~mm}$; breadth $0.1 \mathrm{~mm}$; thickness, 0.01 to $0.02 \mathrm{~mm}$.

Occurrence.-Spiroloculina oretace $a$ Reuss is the onl"r species of this genus so far reported from the American Cretaceous. It has been found in beds of Taylor and Austin ages (Cushman, 1946, p. 49).

The Pierre specimen was found in locality 37 , sample 1,47 feet below the lower key bentonite.

\section{Genus QUINQUELOCULINA d'Orbigny, 1826}

Quinqueloculina sp.
Plate 5, figures 4a-c

Remarks.-Included under this designation are specimens from nine samples and four different localities All specimens but one are preserved as internal molds in silica, and this lack of well-preserved specimens has made species identification impossible. Dimensions of average-sized specimens: length, 0.2 to $0.25 \mathrm{~mm}$; breadth, about $0.2 \mathrm{~mm}$; thickness 0.15 to $0.2 \mathrm{~mm}$.

Occurrence.-Distribution of this species is sporadic. It occurs most commonly in the Pierre Shale within 80 feet of the Fox Hills Sandstone but is also found 42 feet above the upper key bentonite and 155 feet belor the lower key bentonite.

\begin{tabular}{|c|c|c|c|}
\hline Locality & Sample & Locality & Sample \\
\hline 3מ- & 9-VR & $52 \ldots \ldots \ldots$ & $5-V R$ \\
\hline 49 & $13-\mathrm{S}$ & $\mathbf{5 3}_{\mathbf{n}}$ & $11-R$ \\
\hline 50 & $5-\mathrm{S}$ & & $13-\mathrm{VR}$ \\
\hline $2 \ldots$ & $1-\mathrm{S}$ & & $17-\mathrm{R}$ \\
\hline & $3-\mathrm{X}$ & & \\
\hline
\end{tabular}

Genus MASSILINA Schlumberger, 1893

Massilina sp.

Remarks.-Six specimens, only one of which is well preserved, are placed here. The well-preserved specimen 
FORAMINIFERA, STRATIGRAPHY, PIERRE SHALE, FOX HILLS SANDSTONE, S. DAK.

has an elliptical outline, elongate cylindrical neck with a round aperture lacking a tooth, long, narrow, rounded chambers, an early part not coiled in a single plane, and a rust-colored slightly calcareous wall which contains no silt grains. In shape, plan of coiling, and most other preserved details, the other five specimens exactly resemble this specimen; however, they have dull-white or whitish-gray very calcareous tests. The specimens do not seem to belong in any previously described species of Massitina and may represent a new species. Dimensions of the well-preserved specimen : length, $0.29 \mathrm{~mm}$; breadth, $0.17 \mathrm{~mm}$; thickness, $0.01 \mathrm{~mm}$.

Occurrence.-The samples from which the specimens came are distributed 25 to about 100 feet below the lower key bentonite in the Grand River sections.

Material.-Six specimens were found.

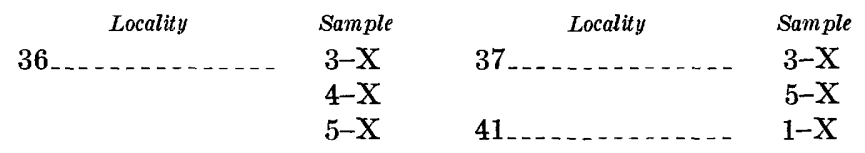

Family TROCHAMMINIDAE

Genus TROChammina Parker and Jones, 1859

Trochammina globigeriniformis Cushman

Plate 1, figures $4 a-c$

Trochammina globigeriniformis Cushman (not Parker and Jones), 1910, U.S. Natl. Mus. Bull. 71 pt. 1, p. 124, text figs. 193-195.

Test trochoid, of about four whorls, equatorial periphery subovate, spiral side strongly convex to conical, umbilical side slightly convex with a small shallow umbilical depression; chambers globular, four in the final whorl, inflated, not compressed, distinct; spiral and septal sutures distinct, depressed, septal sutures short, oblique on spiral side, straight and radial on umbilical side; wall very finely arenaceous, noncalcareous, smoothly finished, with a subordinate amount of cement : aperture not well exposed in available specimens, apparently a low-arched slit between the margin of the final chamber and the previous whorl extending from the periphery onto the umbilical side. Dimensions of the plesiotype, the only well-preserved specimen : maximum diameter, $0.22 \mathrm{~mm}$; minimum diameter, $0.20 \mathrm{~mm}$.

Remarks.-Cushman (1910, p. 124) placed some Recent specimens of Trochammina under the specific name globigeriniformis. He derived this name by placing Lituola nautiloidea (Lamarck) var. globigeriniformis Parker and Jones in the genus Trochammina and raising the name globigeriniformis from varietal to specific rank. This action seems to me to be in error because the aperture of Lituola is cribrate, whereas Trochammina has an interiomarginal aperture. In describ- ing their rariety, Parker and Jones mentionod no difference in aperture from that of the parent species. $L$. nautiloidea (Lamarck). If Parker and Jonєs' variety does have a cribrate aperture, it cannot be placed in Trochammina. As Cushman explicitly stated that his specimens do have an interiomarginal aperture, he is correct in placing them in Trochammina but ir correct in crediting the species designation to Parker and Jones as their variety (Cushman's species) globigeriniformis presumably belongs in the genus Lituola. This question cannot be properly resolved until specimens of $L$. nautiloidea (Lamarck) var. globigeriniformis Parker and Jones are available for comparison with specimens of T. globigeriniformis of Cushman.

The Pierre specimens are smaller on the average than specimens of T. globigeriniformis Cushman in the U.S. National Museum collections, but there is sufocient size variation to include the Pierre specimens. In other respects agreement is good.

Occurrence.-This species has been reported, as Trochammina globigeriniformis (Parker and Jones), from Cretaceous deposits of Switzerland, Trinidad, Peru, Venezuela, England, Bulgaria, U.S.S.R., cnd tentatively from Poland.

The few specimens obtained from the upper part of the Pierre Shale came from 70 feet below the lower key bentonite to 64 feet above the upper key bentonite.

Material.-Fewer than 25 specimens were sufficiently well preserved to be identified.

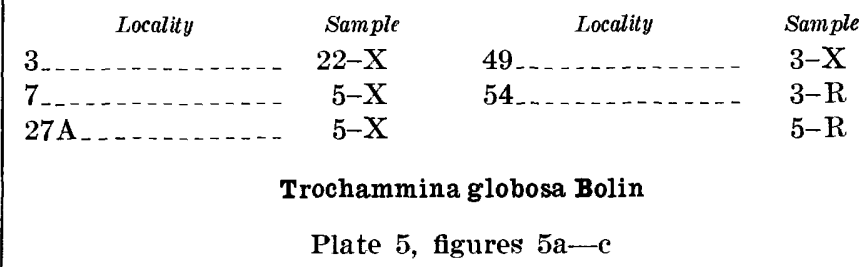

Trochammina globosa Bolin, 1956, Jour. Paleontology, v. 30, no. 2 , p. 289 , pl. 38 , figs. 8,9 ; text fig. 5 , fig. $7 \mathrm{a}, \mathrm{l}$.

Test in a low trochoid spire, equatorial periphery lobulate and roughly circular, spiral side noderately convex, umbilical side with a prominent centj"al depression encircled by the inflated chambers; chambers in final whorl vertically compressed, overlapping, moderately inflated, indistinct in earlier whorls; sutures distinct in final whorl, depressed, straight and oblique on spiral side, straight and radial on umbilical side; wall rather smoothly finished, white to yellow, composed predominantly of clear arenaceous grains the size of which varies quite noticeably, percentage of cement small; aperture an elongate interiomarginal opening extending from the periphery onto the umbilical side but apparently not extending into the umbilicus. Dimensions of average-sized specimens: marimum di- 
ameter about $0.3 \mathrm{~mm}$; minimum diameter, about 0.25 $\mathrm{mm}$; thickness, 0.15 to $0.2 \mathrm{~mm}$.

Remarks.-The above description is based primarily on the features exhibited by two well-preserved specimens. They somewhat resemble Trochammina albertensis Wickenden but differ in having indistinct earhier chambers and sutures and in having the sutures of the last-formed whorl distinctly depressed. The Pierre specimens agree well with the description and figures of $T$. globosa Bolin, but they are somewhat larger and have a more easily observable aperture.

Occurrence.-The species was found 172 to 190 feet above the upper key bentonite in two sections of the Grand River stratigraphic sequence. Bolin (1956, p. 289) reported it from the Cretaceous of Minnesota.

Material.-About 10 identifiable specimens were found.

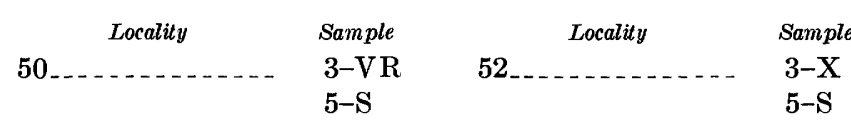

Family LAGENIDAE

Genus ROBULUS Montfort, 1808

Robulus muensteri (Roemer)

Plate 5, figures 6a, b

Robulina münsteri Roemer, 1839, Versteinerungen morddeutschen Oolithengebirges, Nachtrag.. p. 48, pl. 22, fig. 29.

Cristellaria münsteri (Roemer). Reuss, 1862, Akad. Wiss. Wien, Math.-naturw. Kl., Sitzungsber., v. 46, pt. 1, p. 77, pl. 9, figs. 3, 4 [1863].

Robulus münsteri (Roemer). Cushman, 1932. Jour. Palentology, v. 6, no. 4, p. 334, pl. 50, figs. $2 a$, b.

Test planispiral, completely involute, not much compressed, with large umbos; periphery sharply angled, slightly keeled; chambers distinct, of uniform shape and increase gradually in size as added, not inflated, eight or nine in final whorl; sutures distinct, slightly to moderately limbate and raised, tangential, slightly curved; wall smooth, glassy, without visible perforations; aperture at the outer peripheral angle, radiate, with a more elongate slit extending a short distance into the apertural face. Dimensions of average-sized specimens: maximum diameter, about $0.5 \mathrm{~mm}$; minimum cliameter, about $0.4 \mathrm{~mm}$; thickness, 0.25 to $0.3 \mathrm{~mm}$.

Remarhs.-The Pierre specimens correspond well with the description of Robulus maensteri given by Cushman (1946, p. 53) and compare favorably with specimens of this species in the U.S. National Museum collections.

Occurrence.-Cushman (1946, p. 53) noted the occurrence of Robutus muensteri in deposits of Austin, Taylor, and Navarro ages in Tennessee, Mississippi,
Texas, and Arkansas. Since 1945 the species has beer reported from the Arkadelphia Marl of Arkansas (Cushman, 1949 p. 4) and the Lawson Limestone of Florida (Applin and Jordan, 1945, p. 132 (list)) $R$. muensteri has also been reported from the Niobrars Formation of South Dakota (Bolin, 1952, p. 21), from the Hilliard Shale of Campanian and Santonian ages in Wyoming (Gauger in Jones, 1953, p. 66-67), and from the Niobrara Formation in Wyoming (Shaw, 1953, table 1).

Other Upper Cretaceous reports of this species are from Colombia, Spanish Sahara, Venezuela, Germany, Poland, Egypt, California (Graham and Clark, 1961, p. 108 (list)), and Maryland (Cushman, 1948, p. 248) and with question from Puerto Rico.

In the upper part of the Pierre Shale this species occurs from 1 foot above the upper key bentonite to $14 \%$ feet below the lower key bentonite.

Material.-Several hundred specimens from a number of samples were found.

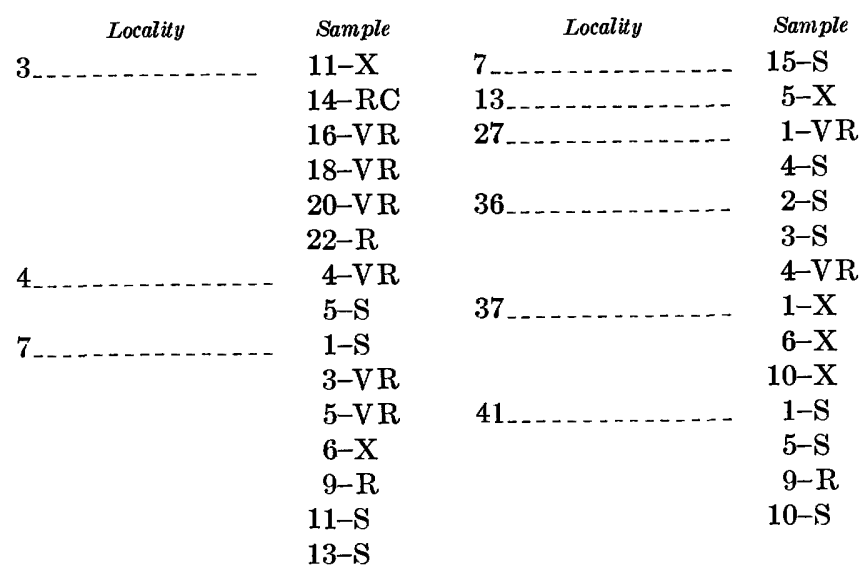

Robulus spissocostatus Cushman

Plate 5, figures $8 \mathrm{a}, \mathrm{b} ; 9 \mathrm{9}, \mathrm{b}$

Robulus spisso-costatus Cushman, 1938, Cushman Lab. Foram. Research Contr., v. 14, pt. 2, p. 32, pl. 5, fig. 2.

Test planispiral, completely involute to partially evolute, moderately compressed, most specimens not umbonate, but umbos developed on some, periphery acute on some specimens, slightly to moderately keelec? on some specimens, a delicate flangelike keel developed on a few specimens; chambers distinct, of uniform shape, increase fairly rapidly in size as added, slightly or not at all inflated, six to 10 in final whorl; sutures usually either flush or raised but occasionally slightly depressed; when raised, sutures are thickest near the center where they either join a central boss or coalesce into a less well defined mass; wall smooth, glassy, without visible perforations; aperture radiate, at the apex 
FORAMINIFERA, STRATIGRAPHY, PIERRE SHALE, FOX HILLS SANDSTONE, S. DAK.

of the periphery of the final chamber, without a prominent extension onto the apertural face. Dimensions of average-sized specimens: maximum diameter, 0.75 to $0.8 \mathrm{~mm}$; minimum diameter, about $0.6 \mathrm{~mm}$; thickness, 0.35 to $0.4 \mathrm{~mm}$.

Remarks.-The specimens here grouped in Robulus spissocostatus, if they are in fact members of the same species, indicate that the species exhibits a wide range of variation in several important characters. The degree of limbation and the elevation of sutures, the degree of involution, the presence and nature of the umbo, the number of chambers in the final volution, and the nature of the keel are all variable. This morphologic variation is impressive, but, as Cifelli (1960) has shown, species of Robulus characteristically vary a great deal in morphology. Cushman (1946, p. 51) pointed out the variability found in Upper Cretaceous species of Robulus.

The variations exhibited by the Pierre specimens are all closely matched by similar variations among the type specimens of $R$. spissocostatus, especially the large group of paratypes of Cushman collection 28380. Cushman $(1946$, p. 52) suggested that there is a great deal of similarity between $R$. spissocostatus and $R$. navarroensis var. extruatus Cushman but stated (p. 53) that $R$. spissocostatus is distinguished from $R$. navarroensis by the lack of a thin, flangelike keel and by the presence of raised sutures that become thick and rounded at the inner ends. However, two of the smaller paratypes of $R$. spissocostatus do have this thin flangelike keel. Moreover, paratypes of $R$. navarroensis var. extruatus have raised and thickened sutures exactly similar to those on some of the paratypes of $R$. spissocostatus. In short, these two forms are very similar and may well belong in the same species, although I do not have sufficient specimens to resolve this question to my own satisfaction.

Occurrence.-Robulus spissocostatus has been reported from stratigraphic units of Navarro age in Texas, Mississippi, Arkansas, and Alabama (Cushman, 1946 , p. 53). Other Cretaceous citations are from Venezuela and Japan.

The Pierre specimens were found from just below the lower key bentonite to 139 feet below this bentonite.

Material.-Fewer than 50 specimens were found.
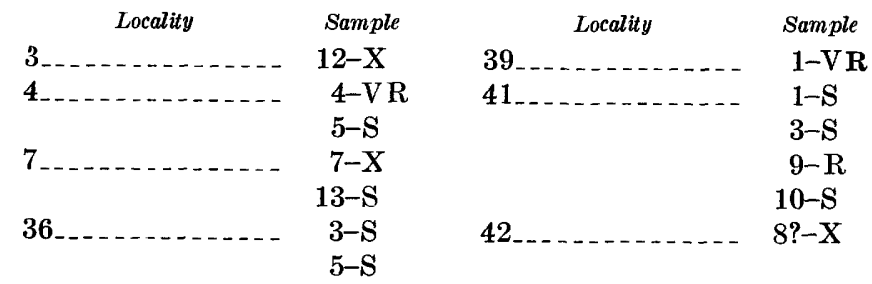

\section{Robulus taylorensis (Plummer)}

Plate 5, figures $7 \mathrm{a}, \mathrm{b}$

Astacolus taylorensis Plummer, 1931, Texas Univ. Bull. 3101, p. 143 , pl. 11, fig. 16 ; pl. 15, figs. 8-11.

Robulus taylorensis (Plummer). Cushman, 1941, Cishman Lab. Foram. Research Contr., v. 17, pt. 3, p. 57, pl. 15, figs. 5 a, b.

Test planispiral, incompletely involute, uncoiling in the final part of largest specimens, only a small part of previous whorls visible in umbilical areas, moderately compressed, umbilical areas flush with the surface of the test or slightly depressed; axial peripl ary acute, with a small keel, equatorial periphery smocth or with slight indentations at the sutures; chambers distinct, of uniform shape, increase gradually in size as added, very slightly if at all inflated, eight to 12 chambers per whorl, usually nine to 11 ; sutures distinct, in some specimens slightly limbate but in most not at all limbate, nearly radial towards the center but beccme gently curved toward the periphery, flush in most specimens, slightly depressed in some; wall smooth, thick, glassy, without visible perforations; aperture radial, at the apex of the apertural face, with an elongate, widened slit extending about one-fourth to one-third the distance down the slightly convex apertural face. Dimensions of average-sized specimens: maximum diameter, about $0.6 \mathrm{~mm}$; minimum diameter, between 0.45 and $0.5 \mathrm{~mm}$; thickness, between 0.15 and $0.2 \mathrm{~mm}$.

Remarks.-None of the specimens becomes completely uncoiled, but in several of the largest specimens, the final few chambers migrate quite far out toward the periphery. In most specimens the proloculus is visible in the umbilical region, but in larger specimens, cloudy shell material covers the proloculus and the er posed part of earlier whorls as succeeding whorls ircrease the thickness of the test.

The specimens closely resemble specimens of Robulus taytorensis in the Cushman Collection but differ from most of these in having a slightly less convex umbilicus, and slightly less tangential sutures.

Occurrence.-Cushman (1946, p. 53) reported this species from Alabama, Mississippi, Texas, and Arkansas from beds of Austin and Taylor ages. To my knowledge this species has not been found in beds of Navarro age.

In the upper part of the Pierre Shale, Robutus taylorensis occurs from 35 feet below the lower key bentonite to just above the upper key bentonite.

Material.-50 to 100 specimens were found.

$\begin{array}{cccc}\text { Locality } & \text { Sample } & \text { Locality } & \text { Sample } \\ 7 \ldots \ldots & 15-\mathrm{S} & 13 \ldots & \\ 11 \ldots \ldots & 21-\mathrm{X} & 41 \ldots \ldots & \\ 13 \ldots \ldots & 2-\mathrm{X} & & 10-\mathrm{S}\end{array}$




\section{Marginulina curvatura Cushman}

Plate 6, figure 1a, $\mathrm{b}$

Marginulina curvatura Cushman, 1938, Cushman Lab. Foram. Research Contr., v. 14, pt. 2, p. 34, pl. 5, figs. 13, 14.

Remarks.-Five fairly well preserved specimens are placed in this species. They match the type description and the holotype of Marginulina curvatura very well except for having a shorter uncoiled part. It seems safe to assume that this difference is due to the failure of the Pierre specimens to reach as advanced a stage of growth as the holotype. Dimensions of a somewhat larger than average-sized specimen: length, $0.45 \mathrm{~mm}$; breadth, 0.22 $\mathrm{mm}$; thickness, $0.20 \mathrm{~mm}$.

Occurrence.-Marginulina curvatura has been reported from the Arkadelphia Marl of Arkansas and the Corsicana Marl of Texas (Cushman, 1946, p. 63), from the Upper Cretaceous of Hokkaido, Japan, and questionably from beds of Cenomanian age near Dresden, Germany.

In the upper part of the Pierre Shale this species occurs from 126 to 25 feet below the lower key bentonite. Material.-Five specimens were found.

$\begin{array}{cccc}\text { Locality } & \text { Sample } & \text { Locality } & \text { Sample } \\ 3 & \text { Marginulina sp. } & \end{array}$

Remarks.-Five similar specimens from four samples were found which appear to belong in the genus $M a r-$ ginulina but which could not be identified to species. They are composed of three to five small oblique, overlapping chambers and are slightly curved in the early part. A radiate, moderately produced aperture is at the apex of the test on the dorsal periphery. The type figure of M. depressa. Blake (Tate and Blake, 1876, p. 463, pl. 19, fig. 9) closely resembles these specimens, but the generalized type description is of little use for making a more detailed comparison. $M$. depressa has not been reported from the Cretaceous. Dimensions of an average-sized specimen: length, about $0.25 \mathrm{~mm}$; breadth, about $0.1 \mathrm{~mm}$.

Occurrence.-The specimens are found 30 to 70 feet below the lower key bentonite.

Material.-Five specimens were found.

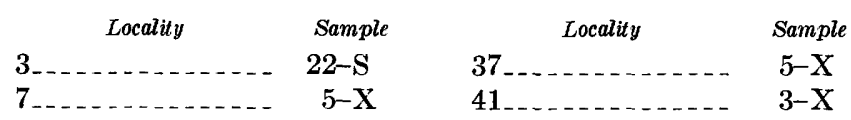

The genera Astacolus and Marginulina

Some confusion surrounds the designation of a type species for the genus Marginulina, which makes it imperative that $I$ discuss the removal herein of several species from Marginulina and their relocation in Astacolus. The genus Marginulina was erected by d'Orbigny
(1826, p. 258). The generic description stated that the test is in the form of an arched scabbard, that the aperture is radiate, marginal, and situated at the tip of a prolongation of the final chamber at the anterior angle, that there is an early coiled part (the degree or amount of coiling is not specified), and that the chambers are superposed and slightly oblique. d'Orbigny did not designate a type species for Marginutina. Deshayes (1832, p. 1107) designated $M$. raphanus (Linné) $=$ Nautilus raphanus Linné, 1758) as the type species of Marginulina. Cushman (1913, p. 79) designated $M$. glabra d'Orbigny, 1826, as the type species of Marginulina. Marie (1941, p. 105, 257, 258) also decided to consider $M$. raphanus (Linné) as the type species. The type specimens of $N$. raphanus and $M$. glabra have not been available to me for study, and my conclusions are based on the type figures and descriptions of these species. The type figures of $N$. raphanus Linné (Ellis and Messina, 1940-1964) show a straight uniserial, Nodosarialike form with no indication of an early coiled part. This form does not correspond to the type description of Marginulina given by d'Orbigny, and it must be concluded that d'Orbigny was ignorant of the true nature of $N$. raphanus Linné (as this nature is indicated by Linné's figures) when he placed the species in Marginulina. Cushman $(1945$, p. 12) reexamined material from Castel Arquato, Italy, one of the localities from which d'Orbigny reported $M$. raphanus (Linné), but he found no specimens identical with d'Orbigny's figure or model of this species.

In view of the apparently incorrect assignment of $N$. raphanus Linné to the genus Marginulina, I prefer to consider $M . g^{7} a b r a$ d'Orbigny as the type speoies of Marginulina, as proposed by Cushman (1913, p. 79). M. glabra corresponds to the type description of $M a r$. ginulina in having an early coiled part, a radiate aperture situated at the tip of a slight prolongation at the apex of the test, and slightly oblique chambers in the uniserial portion. In addition, this species was named by d'Orbigny and placed by him in his genus $M$ Larginulina.

The genus Astacolus, erected by Denys de Montfort in 1808 , is poorly described, and the type figure is also very poor. However, the type species, Nautilus crepidula: Fichtel and Moll was well figured by the original authors. This species differs from the type species of $M \mathrm{ar}^{2}$ ginulina in having the chambers of the uniserial part extending well back toward the proloculus on the ventral side and in having the early chambers more loosely coiled. It is primarily on the basis of these two characteristics, especially the extension of the uniserial chambers toward the proloculus, that I have separated Astacolus from Marginulina. 


\section{The genera Astacolus and Vaginulina}

For a number of years the genus Astacolus was ignored by most workers in Foraminifera, and species that could have been placed in this genus were placed, for the most part, in the genera Marginulina and Vaginutina. The genus Astacolus is valid and in my opinion serves a useful purpose-under this generic name can be placed those species that are laterally compressed and partially coiled in the early part, become uniserial and gently curved Iater, and have rather oblique chambers which extend back toward the proloculus. All these characteristics are shown by the type species of Astacolus, A. crepidulus (Fitchel and Moll) (=Nautitus crepidula Fichtel and Moll). The type species of Vaginutina, V. Tegumen (Linné) $(=$ Nautilus legumen Linné) is similar to Astacolus in many respects but differs in being slightly if at all compressed laterally and in having only slightly oblique chambers which do not extend back appreciably toward the initial end. It seems desirable to utilize these differences in placing species in Astacolus and Vaginulina, respectively.

\section{Genus ASTACOLUS Montfort, 1808}

Astacolus cretaceus (Cushman)

Plate 6, figures 2a-d

Marginulina cretacea Cushman, 1937, Cushnan Lab. Foram. Research Contr., v. 13, pt. 4, p. 94, pl. 13, figs. 12-15. Astacolus cretaceus (Cushman). Pozaryska, 1957, Paleont. Polonica, no. 8 , p. 98, pl. 11, figs. 11,$12 ;$ pl. 13, fig. 7 .

Remarks.-The single complete, well-preserved specimen, of the few that are referred to this species, compares almost perfectly with the holotype of this species and quite well with the paratypes. This species differs from Cushman's (1946, p. 60, pl. 12, figs. 4, 5) description and figures of Marginulina cf. Mr. recta, in having shorter, ventrally narrower, less oblique chambers, fewer of which reach back to the early part of the test. The Pierre specimens resemble $\boldsymbol{M}$. siliqua. Cushman a great deal but differ in having a more concave ventral side, continually increasing size of chambers with growth, and a less pronounced extension of the chambers toward the earlier part of the test. Dimensions of the plesiotype: length, $0.56 \mathrm{~mm}$; breadth, $0.24 \mathrm{~mm}$; thickness, $0.18 \mathrm{~mm}$.

Occurrence.-Cushman (1946, p. 61) recorded this species from beds of Taylor and Navarro ages in Texas and Arkansas. The species has also been recorded from the Hilliard Shale in Wyoming (Gauger, in Jones, 1953, p. 68), from the Upper Cretaceous in Maryland (Cushman, 1948a, p. 250), from beds of Campanian age in California (Graham and Clark, 1961, p. 108 (list)), and from the Upper Cretaceous of France, Poland, and Puerto Rico.
In the upper part of the Pierre Shale this species occurs from 32 feet below to just above the upper key bentonite.

Material.-Fewer than 10 specimens were found.

$\begin{array}{cccc}\text { Locality } & \text { Sample } & \text { Locality } & \text { Sample } \\ 27 & 1-\mathrm{X} & 45 \ldots \mathrm{X} \\ 4-\mathrm{S} & & 7-\mathrm{S} \\ & \text { Astacolus rectus (d'Orbigny) } \\ & \text { Plate 6, figures } 3 \mathrm{a}, \mathrm{b}\end{array}$

Cristellaria recta d’Orbigny, 1840, Soc. géol. France Mém., v. 4 , p. 28, pl. 2, figs. 23-25.

Enantiovaginulina recta (d'Orbigny). Marie, 1941, Mus. Histoire Naturelle, Mém., new ser., v. 12. pt. 1, p. 161, pl. 21, figs. 235a-e.

Astacolus rectus (d'Orbigny). Hagn, 1953, Paleortographic, v. 104 , pts. A, p. 39, pl. 5, fig. 16.

Test elongate, compressed, early part partially coiled, rapidly uncoiling; ventral periphery smooth, straight to slightly concave, dorsal periphery smocth, convex, dorsal margin sharply rounded, ventral margin smoothly rounded, uncoiled part subtriangular in cross section; chambers distinct, slightly if at all inflated, increase rather rapidly in length but more gradually in breadth and thickness as added; final chambers in large specimens do not reach back to the early coiled port; sutures distinct, slightly curved, flush to slightly depressed; wall smooth, semitransparent, lacks visikle perforations; aperture radiate, at the outer peripheral angle; apertural face shightly convex, with smoothly rounded edges, steeply inclined. Dimensions of an average-sized specimen with final chamber extending nearly to the proloculus; length, $0.37 \mathrm{~mm}$; breadth, $0.17 \mathrm{~mm}$; thickness, $0.12 \mathrm{~mm}$. Dimensions of a specimen in which the final chamber does not extend as far towerd the proloculus: length, $0.47 \mathrm{~mm}$; breadth, $0.14 \mathrm{~mm}$; thickness, $0.11 \mathrm{~mm}$.

Remarks.-The final chamber on several specimens is much smaller than the preceding chambers and only partially covers the apertural face of tha preceding chamber.

This species differs from Astacolus cretaceus (Cushman) in its more smoothly rounded ventral margin and its subtriangular outline in cross section. d'Orbigny's type description of $C$ ristellaria recta and the type figure resemble the Pierre material rather closely, as does the description and fignre given by Hagn for $A$. rectus (d'Orbigny). Cushnian recognized a form that he considered similar to $A$. recta from the Cretaceous rocks of the United States Gulf Coast and designated it Marginulina cf. $M$. recta (d'Orbigny). An exemination of some of the slides of Marginutina cf. $M$. recta in the U.S. National Museum collections revealed close similarity of the Pierre material with the plesiotypes and 
identity with those specimens (unfigured) on Cushman collection slide 28733 from the upper part of the Taylor Marl.

Occurrence.-This species has been reported from the upper part of the Taylor Marl and the Pecan Gap Chalk Member of the Taylor Marl in Texas (Cushman, 1946, p. 60) and from Upper Cretaceous strata near Salisbury, Md. (Cushman, 1948a, p. 249). It has also been reported from the Cretaceous of Czechoslovakia and from the upper Campanian of Germany.

In the upper part of the Pierre Shale, Astacolus rectus (d'Orbigny) occurs from 115 feet below the lower key bentonite to 24 feet above the upper key bentonite. Material.-Fewer than 50 specimens were found.

\begin{tabular}{|c|c|c|c|}
\hline Locality & Sample & Locality & Sample \\
\hline $3_{-1, n}$ & $\begin{array}{l}16-V R \\
18-X\end{array}$ & 7 & $\begin{array}{l}6-X \\
7-S\end{array}$ \\
\hline$\ldots \ldots$ & $4-S$ & & $25-X$ \\
\hline & $5-\mathbf{R}$ & 27. & $6-X$ \\
\hline 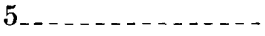 & $4-\mathrm{S}$ & & $9-X$ \\
\hline$\ldots$ & $1-\mathrm{S}$ & $42 \ldots$ & $8-X$ \\
\hline
\end{tabular}

Astacolus jarvisellus Mello, new name

Plate 6, figures $4 a, b$

Marginulina jarvisi Cushman, 1938, Cushman Lab. Foram. Research Contr., v. 14, pt. 2, p. 35, pl. 5, figs. 17. 18.

Astacolus jarvisi (Cushman) (not Astacolus jarvisi Brotzen, 1936). Trujillo, 1960, Jour. Paleontology, v. 34, no. 2, p. 317, pl. 46, fig. 2 .

Remarks.-The few specimens found are characterized by a compressed test with early coiled part, straight or slightly concave ventral side, straight or slightly convex dorsal side, an oval outline in cross section, equally and rather abruptly rounded lateral peripheries, and moderately oblique chambers. The Pierre specimens compare well with plesiotypes of this species.

Astacolus jarvisi Brotzen (Brotzen, 1936, p. 56, pl. 3, figs. 5a, b, 6, 7 , text fig. 17) from the Upper Cretaceous of Sweden is not the same species as Marginutina jarrisi Cushman. Therefore, in placing $M$. jarvisi Cushman in the genus Astacolus, I have changed the species name to jarvisellus. Dimensions of average-sized specimens: length, 0.35 to $0.4 \mathrm{~mm}$; breadth, 0.1 to $0.15 \mathrm{~mm}$; thickness 0.05 to $0.1 \mathrm{~mm}$.

Occurrence.-Astacolus jarvisellus has been reported, as Marginulina jarvisi, from the Kemp Clay (Navarro age) of Texas (Cushman, 1946, p. 63) and from the Upper Cretaceous of Mexico and Venezuela. It has also been reported, as Astacolus jarvisi. from beds of Coniacian and Santonian ages in California (Trujillo, 1960, p. 317).

In the upper part of the Pierre Shale this species was found only at locality 7 from 70 to 36 feet below the lower key bentonite.

Material.-Fewer than 20 specimens were found.

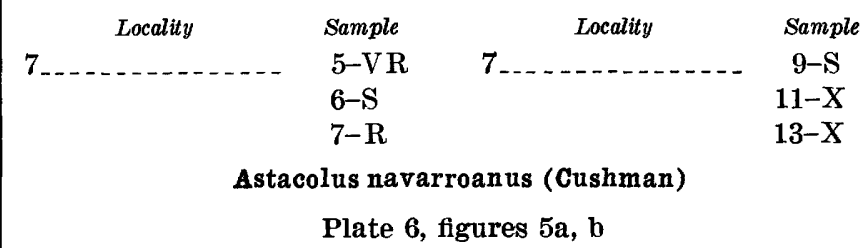

Vaginulina navarroana Cushman, 1936, Geol. Soc. America Bull., v. 47, no. 3, p. 416, pl. 1, fig. 3 .

Astacolus navarroanus (Cushman). Perlmutter and Todd, 1965, U.S. Geol. Survey Prof. Paper 483-I, p. 11, pl. 1, fig. 9.

Test elongate, somewhat compressed, early part slightly curved, later part straight, periphery rounded, ventral side straight to slightly concave, not interrupted, dorsal side straight in later part, convex in early part, initial end with or without a small spine; chambers distinct, slightly inflated, oblique, moderately overlapping, higher than broad, appear broader than high when overlapped, six in the largest specimen, of uniform shape except for the more bulbous proloculus, increase very gradually in size as added; sutures distinct, slightly depressed, oblique, curve slightly downward; wall ornamented with about 11 longitudinal, nearly vertical costae, often in the form of thin flanges that are continuous across sutures and chambers alike, best developed in early part, become weaker and less numerous in later part, completely absent in upper half of final chamber; aperture radiate, terminal, at the dorsal angle. with a short neck. Dimensions of the only complete specimen in addition to the plesiotype: length, $0.7 \mathrm{E}$ $\mathrm{mm}$; breadth, $0.15 \mathrm{~mm}$; thickness, $0.11 \mathrm{~mm}$.

Remarks.-Only four specimens from a single sample were found, and all are macrospheric forms. They fit the description of Astacolus navarroanus (Cushman) quite well and are closely similar to the holotype except that they are less compressed in the early part because of the large size of the proloculus. The Pierre specimens most closely resemble the plesiotype of this species illustrated by Cushman (1946, pl. 29, fig. 22) from the Bulimina zone of the Corsicana Marl of Texas.

Occurrence.-This species has been reported from beds of Navarro age in Mississippi, Texas, and Arkansas (Cushman, 1946, p. 81) and from the Arkadelphia Marl of Navarro age in Arkansas (Cushman, 1949, p. 6). The holotype comes from Cretaceous deposits on Georges Bank (Cushman, 1936, p. 416). The species has also been reported from the Cretaceous of New Jersey (Olsson, 1960, p. 20), New York (Perlmutter and Todd, 1965, p. 11), Colombia, and Africa.

The Pierre specimens come from 12 feet above the lower key bentonite.

Material.-Four specimens were found.

$\begin{array}{cc}\text { Locality } & \text { Sample } \\ 7 & \end{array}$




\section{Astacolus dissonus Plummer}

Plate 6, figure 6

Astacolus dissonus Plummer, 1931, Texas Univ. Bull. 3101, p 145, pl. 11, figs. 17, 18; pl. 15, figs. $2-7$.

Test planispiral, completely involute except uncoiling in some larger specimens, quite compressed, not umbonate, periphery on smaller specimens sharply angled and in some slightly keeled, larger specimens with a broad, thin, delicate keel; chambers distinct, in the shape of elongate curved triangles, increase in length rather rapidly as added, early chambers slightly or not at all inflated, later chambers slightly inflated, seven to .nine in the final whorl of larger specimens; sutures distinct, in smaller specimens generally moderately limbate and in larger specimens slightly or not at all limbate, nearly radial at the point of junction, gently arched away from the aperture as they approach the periphery, flush with the surface or slightly depressed between slightly inflated chambers; wall smooth, glassy, without visible perforations; aperture radiate, at the apex of the final chamber, lacks a prominent slit in the apertural face; apertural face slightly convex, with rounded edges, not sharply set off from the chamber sides. Dimension of average-sized specimens: maximum diameter, about $0.65 \mathrm{~mm}$; minimum diameter, 0.45 to $0.5 \mathrm{~mm}$; thickness, about $0.1 \mathrm{~mm}$.

Remarks.-Only a few specimens are assigned here with confidence. The other specimens exhibit a wide range of variation and may in fact belong in another species. Similar variants, labeled as Planularia dissona, were found in the U.S. National Museum collections. The type figures for this species (Plummer, 1931, pl. 11, figs. 17,18 ; pl. 15, figs. 2-7) also show a range of variation which is similar in most respects to that exhibited by the Pierre specimens.

This species is placed in the genus Astacolus rather than in the genus Planularia, where it has been most frequently placed in the past, because it more closely resembles Nautilus crepidula. Fichtel and Moll, the type species of Astacolus, than it does Peneroplis auris Defrance, the type species of Planularia.

Occurrence.-This species has been reported from beds of Navarro age in Texas and Arkansas by Cushman $(1946$, p. 57). It has also been reported from the Red Bank Sand of New Jersey (Olsson, 1960, p. 11) and from Upper: Cretaceous deposits in Long Island Sound (Perlmutter and Todd, 1965, pp. 11).

In the upper part of the Pierre Shale this species is found from 25 feet below to 6 feet above the lower key bentonite.

Material.-Fewer than 20 specimens were found.

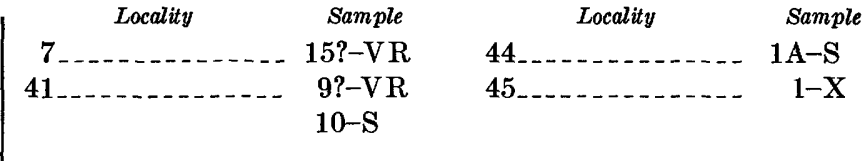

Genus DENTAIINA d'Orbigny, 1826

Dentalina catenula Reuss

Plate 6, figure 7

Dentalina catenula Reuss, 1860, Akad. Wiss. Wien, Math.naturw. Kl., Sitzungsber., v. 40, p. 185, pl. 3, fig. 6.

Test elongate, straight, tapers in microspheric individuals, with parallel sides in megalospheric individuals, initial end with a distinct spine; chambers. few, pyriform, of uniform shape, all but final chamber appears globular because of slight overlapping; sutures distinct, strongly depressed; wall smooth; apertur? terminal, radiate. Dimensions of an average-sized two-chambered specimen : length, $0.55 \mathrm{~mm}$; breadth, $0.24 \mathrm{~mm}$.

Remarks.-Specimens referable to this species are few, and no specimen preserves more than five chambers. Nevertheless, the smooth surface, pyriforn chamber shape, deep sutural depressions, and basal soine are diagnostic criteria which allow a reasonably crrtain identification.

Occurrence-Dentalina catenula has been reported from the beds of Taylor and Navarro ages in Alabama, Texas, and Arkansas (Cushman, 1946, p. 68). Other United States occurrences are from the Upper Cretaceous of California (Trujillo, 1960, p. 327; Cushman and Church, 1929, p. 509) and Maryland (Cushman, 1948a, p. 251). It has also been reported from the Cretaceous of Germany, Palestine, Switzerland, tta Spanish Sahara, Venezuela, Poland, Egypt, Angsla, Japan, Australia, and Puerto Rico.

In the upper part of the Pierre Shale this species occurs from just below the lower key bentonite to 103 feet below this bentonite.

Material.-Fewer than 20 specimens were found.

\begin{tabular}{|c|c|c|c|}
\hline \multirow{4}{*}{\begin{tabular}{c}
\multicolumn{2}{c}{ Locality } \\
3
\end{tabular}} & Sample & Locality & Sample \\
\hline & 18-VR & 7 & $9-\mathrm{VR}$ \\
\hline & $20-\mathrm{VR}$ & & $11-\mathrm{S}$ \\
\hline & 22-S & $42 \ldots \ldots$ & 8-S \\
\hline
\end{tabular}

Dentalina niobrarensis Loetterle

Plate 6, figures $8 \mathrm{a}, \mathrm{b}$

Dentalina niobrarensis Loetterle, 1937, Nebraska Geol. Survey Bull. 12, 2d ser., p. 24, pl. 2, fig. 3.

Remarks.-Assignment of the Pierre specimens to this species is made with some hesitation bea ause of the scarcity of good specimens and because the species does not have many distinctive morphologic parameters on which to base comparisons. The specimens available 
correspond quite well to Loetterle's type figures and description, but they also appear to be similar to the type figures and description of Marginulina subtilis Brotzen. No comparative specimens of either species were seen. Dimensions of average-sized specimens: length, 0.25 to $0.3 \mathrm{~mm}$; breadth, about $0.1 \mathrm{~mm}$.

Occurrence.-Dentalina niobrarensis Loetterle was originally described from the Niobrara Formation in Nebraska (Loetterle, 1937, p. 24) and since then has only been reported once, from the Niobrara Formation in South Dakota (Bolin, 1952, p. 28).

The species occurs from the level of the lower key bentonite to 69 feet below this level in the upper part of the Pierre Shale.

Material.-Fewer than 15 specimens were found.

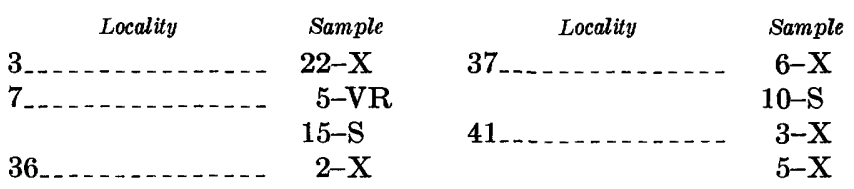

Dentalina cf. D. consobrina d'Orbigny

Plate 6, figures 9a, b

Remarks.-A slightly bulbous initial chamber, straight or very slightly arched test, and chambers that increase considerably in height but little in breadth as added are characteristic features of the Pierre specimens. In these respects the specimens are similar to Dentalina consobrina d'Orbigny. Only three of 10 specimens that have the initial chamber preserved have a sharp basal spine, a character described by d'Orbigny for his species. No specimen with the aperture preserved was found. Dimensions of an incomplete specimen composed of proloculus and four chambers: length, 1.41 $\mathrm{mm}$; breadth, $0.08 \mathrm{~mm}$.

The Pierre specimens closely correspond to Cretaceous specimens in the U.S. National Museum collections labeled Dentalina cf. D. consobrina from the Selma Group in McNairy County, Tenn. (Cushman colln. 15164), and from 1,410-1,420 feet in the Ohio Oil Co. Hammond well 1 in eastern Maryland (Cushman colln. 62029 ). These specimens are the best preserved of any American Cretaceous specimens bearing this designation in the U.S. National Museum collections. Topotypes of D. consobrina from Baden, Austria (Cushman colln. 17167), are also closely similar to the Pierre specimens and to the specimens from Tennessee and Maryland mentioned above, but they differ in being somewhat stouter in proportion to their length.

These similarities indicate that the Pierre specimens are morphologically very close to and perhaps are conspecific with $D$. consobrina. However, because of the difference in proportions between the Pierre specimens and the topotypes and because of the absence of any specimen in the Pierre samples on which the apertur? is preserved, only a tentative assignment to $D$. conscbrina is made.

Occurrence.-Dentalina consobrina has been reported from beds of Taylor and Navarro ages in Texas and Tennessee (Cushman, 1946, p. 69, 70). It has also been reported from Europe, Japan, Palestine, South America, and from the Campanian of California (Grahar and Clark, 1961, p. 108).

This species occurs in samples from 6 feet above th lower key bentonite to 126 feet below this level.

Material.-Fewer than 50 specimens were found.

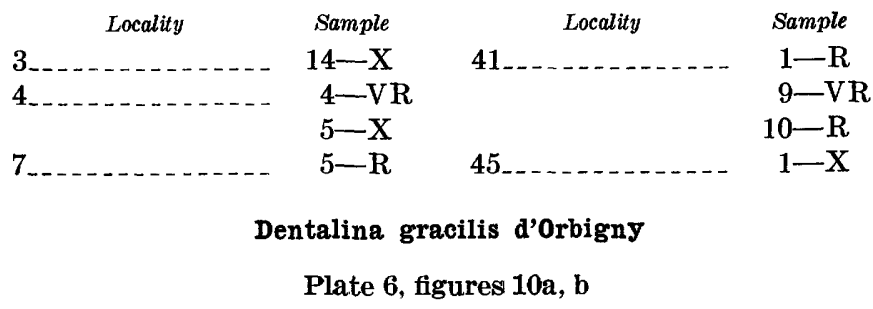

Dentalina gracilis d'Orbigny, 1840, Soc. géol. France Mém., 1st ser., จ. 4, p. 14, pl. 1, fig. 5.

Test elongate, slender, gently arched, initial end pointed in most specimens, chambers slightly if at all inflated, increase gradually in size as added, moderately overlapping; sutures flush or slightly depressed, shightly oblique to axis of elongation; wall smooth, finely perforate; in a few well-preserved specimens the upper third of the final chamber is more transparent than the lowen part, and a small triangle of clear shell persists beneath the aperture of each overlapped chamber; the clear shell area is apparently not perforate; aperture radiate, moderately produced, at the inner or concave periphery of the test. Dimensions of average-sized specimens: length about $0.7 \mathrm{~mm}$; breadth, about $0.1 \mathrm{~mm}$.

Remarks.-The specimens with the distinctive pattern of clear and cloudy shell material are matched perfectly by specimens of Dentalina gracilis from the Kemp Clay (Cushman colln. 29236) and from the Matawan Formation in Ohio Oil Co. Hammond well 1 from 1,410-1,42) feet (Cushman, colln. 62003). These specimens resembls D. lequmen Reuss rather closely but are distinguished by the less oblique sutures and chambers.

Occurrence-Dentalina gracilis has been reported from beds of Austin, Taylor, and Navarro ages in tha Gulf Coast Cretaceous (Cushman, 1946, p. 65-66), from the Hilliard Shale of Campanian and Santonian ages in Wyoming, Gauger, in Jones, 1953, p. 70), from the Frontier Formation of Campanian and Santonian age: in Utah (Peterson, in Jones, 1953, p. 34), and from th? Upper Cretaceous of Maryland (Cushman, 1948a, r. $250)$. This species has also been reported from the Cre- 
taceous of France, Germany, Switzerland, Poland, England, Trinidad, Venezuela, Egypt, and Australia.

In the upper part of the Pierre Shale the species ranges from just below to 126 feet below the lower key bentonite.

Material.-Fewer than 50 specimens were found, and well-preserved specimens are very few.

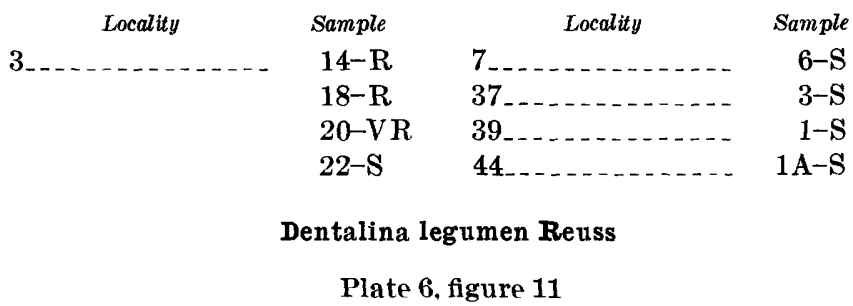

Dentalina legumen Reuss, 1851, Haidinger's Naturw. Abh., v. 4, p. 10, pl. 1, fig. 14 .

Test elongate, slender, straight to slightly arched, lacks a basal spine; chambers slightly to moderately inflated, increase gradually in size as added, slightly to moderately overlapping; sutures slightly to moderately depressed, vary in angle from about $20^{\circ}$ to $45^{\circ}$ to the axis of elongation; wall smooth, in some specimens transparent, finely perforate; aperture radiate, slightly to moderately produced, at the inner or concave margin of curved specimens. Dimensions of average-sized specimens : length, 0.25 to $0.3 \mathrm{~mm}$; breadth, about $0.1 \mathrm{~mm}$.

Remarks.-Inflation of chambers, angle of sutures, and test size and shape are quite variable among the group of specimens here assigned to Dentalina legumen, but the specimens appear to belong together in a single species. The range of variation credited to this species, primarily by Cushman (1946, p. 65), exceeds the limits of variation shown by the Pierre specimens.

nccurrence.-Dentatina legumen has been reported from beds of Austin, Taylor, and Navarro ages in the Gulf Coast deposits. The only other North American occurrence is from the Upper Cretaceous of Maryland (Cushman, 1948a, p. 250). Elsewhere this species has been recorded from the Cretaceons of the U.S.S.R., Germany, France, Czechoslovakia, Trinidad, Palestine, Sweden, Switzerland, the Spanish Sahara, the Netherlands, Venezuela, England, Egypt, and Poland.

In the upper part of the Pierre Shale, D. Legumen occurs from 12 feet above the upper key bentonite to 144 feet below the lower key bentonite.

Material. -50 to 100 specimens were found.

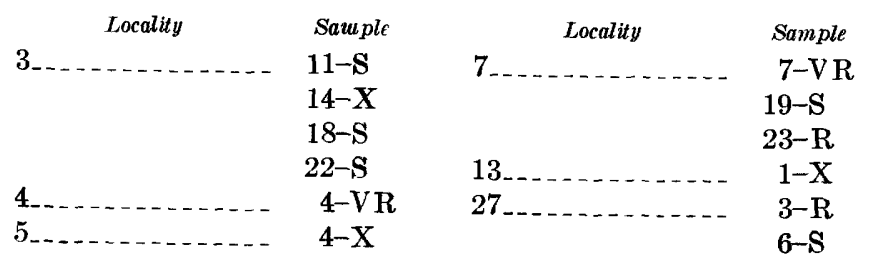

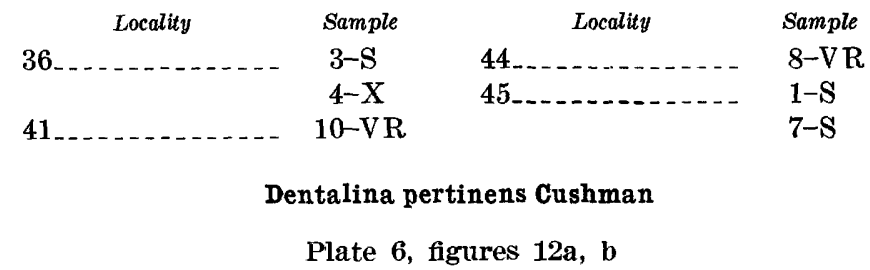

Dentalina pertinens Cushman, 1938, Cushman Lab Foram. Research Contr., v. 14, pt. 2, p. 40, pl. 6, figs. 15-18.

Test elongate, slightly arched, tapers moderately rapidly, rather stout for a species of this genus; chambers of the early part indistinct and not inflated, gradually become more inflated, less overlapping, and more distinct; sutures indistinct in early part, become progressively depressed and distinct toward apertural end, slightly limbate; wall quite thick, ornamented by rather heavy costae, which are twisted and continuous across several chambers in the early part and become finer, more numerous, less continuous, and less twisted on later chambers; aperture radiate, slightly projecting, toward the convex margin of the test. Dimensions of the best preserved specimen, the plesiotyze: length $0.83 \mathrm{~mm}$; breadth, $0.25 \mathrm{~mm}$.

Remarks.-Very few specimens of this species were found, but their distinctive ornamentation and shape are diagnostic. They agree exactly with tha holotype. The single specimen with the early chambers preserved has two short basal spines.

Occurrence.-In North America Dentalina pertinens has been reported from the upper part of the Taylor Marl and upper part of the Selma Group in Mississippi and Texas (Cushman, 1946, p. 70) and from the Upper Cretaceous of Maryland (Cushman, 1948a, ]. 252). The species has also been reported from the Crotaceous of Australia.

In the upper part of the Pierre Shale, D. pertinens occurs immediately below the lower key lantonite in two sections along the Grand River and $8 \stackrel{i}{ }$ feet below this bentonite in one section along the Moreau River.

Material.-Fewer than five specimens were found.

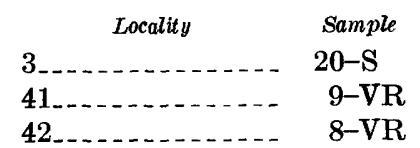

\section{Dentalina solvata Cushman}

Plate 6, figures 13, 14

Dentalina solvata Cushman, 1938, Cushman Lak. Foram. Research Contr., v. 14, pt. 2, p. 39, pl. 6, figs. ?-14.

Remarks.-A few slightly arcuate specimens are placed in this species on the basis of the globular chambers and the fairly numerous heavy costae which traverse early chambers and flush sutures and later become 
confined to the progressively wider and more indented sutural areas. One specimen preserves the early part of the test, which has a small pointed basal spine. The holotype for this species has been lost, and comparison was made with the paratypes. Dimensions of the smaller plesiotype, one of the few nearly complete specimens: length, $0.59 \mathrm{~mm}$; breadth, $0.09 \mathrm{~mm}$.

Occurrence.-Dentalina solvata has been reported from beds of Austin, Taylor, and Navarro ages in the Gulf Coast deposits (Cushman, 1946, p. 69), from the Frontier Formation of Campanian-Santonian age in Utah (Peterson, in Jones, 1953, p. 37), from the Hilliard Shale of Campanian-Santonian age in Wyoming (Gauger, in Jones, 1953, p. 71), and from the Upper Cretaceous of Maryland (Cushman, 1948a, p. 252). To my knowledge these are the only reported occurrences of this species.

In the upper part of the Pierre Shale, D. solvata is present 126 to 65 feet below the lower key bentonite.

Material.-Fewer than 30 specimens were found.

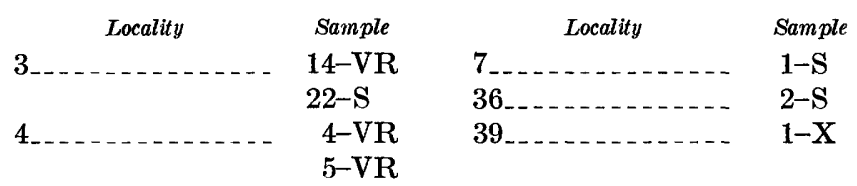

Genus NODOSARIA Lamarck, 1812

Nodosaria affinis Reuss

Plate 6, figure 15

Nodosaria affinis Reuss, 1845, Versteinerungen Böhmischen Kreideformation, pt. 1, p. 26, pl. 13, fig. 16.

Remarks.-The few specimens assigned to this species are characterized by globular chambers not closely appressed and separated by moderately depressed sutures and by numerous platelike costae which extend the length of the test, continuing across both sutures and chambers. The specimens are larger, have less closely appressed chambers, more elevated costae, and are straighter than the specimens placed in Dentalina solvata Cushman. Dimensions of the plesiotype, the most nearly complete specimen: length, $1.06 \mathrm{~mm}$; breadth, $0.21 \mathrm{~mm}$.

Occurrence.-Nodosaria affinis has been reported from beds of Austin, Taylor, and Navarro ages in the Gulf Coast deposits (Cushman, 1946, p. 71), from the Upper Cretaceous of Maryland (Cushman, 1948a, p. 252), and from the Hilliard Shale of Wyoming (Gauger, in Jones, 1953, p. 70-71). This species has also been reported from Cretaceous deposits in Hungary, Czechoslovakia, Poland, Germany, Ireland, Antigua, Trinidad, Cuba, Venezuela, Argentina, Egypt, South Africa, and Australia.

323-073 $0-69-5$
The specimens from the upper part of the Pierre Shale come from immediately below the lower key bentonite and from 48 feet above the upper key bentonite. Material.-Three specimens were found.

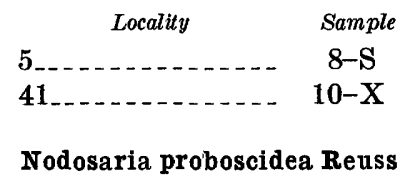

Plate 6, figure 16

Nodosaria proboscidea Reuss, 1851, Haidinger's Naturw. Abh., v. 4 , pt. 1 , p. 7 , pl. 1 , fig. 6 .

Test elongate, straight, composed of two to six slightly to moderately overlapping globular chambers; either the first or last chamber is largest in the Pierre specimens, and chambers smaller than those adjacent may occur anywhere in the test; sutures slightly to moderately depressed depending on degrees of overlap and inflation of chambers; wall translucent in some specimens but generally opaque, of moderate thickness, ornamented by seven to 14 longitudinal costae which are usually thin and platelike; costae extend the length of the test over both sutures and chambers and increase in number by bifurcation of individual costae at chamber bases; aperture apparently broken off in all specimens, leaving a round or irregular opening at the apex of a cylindrical neck; a collar of shell material surrounds the base of the apertural neck, and against this structure some or all of the costae terminate. Dimensions of average-sized specimens: length, about $0.6 \mathrm{~mm}$; breadth, about $0.15 \mathrm{~mm}$.

Occurrence.-Cushman (1946, p. 72) reported this species from beds of Taylor age in the Gulf Coast deposits, but specimens are rare. It has also been reported from the Upper Cretaceous of Maryland (Cushman, 1948a, p. 253) and from the Cretaceous of Hungary, England, and Puerto Rico.

In the upper part of the Pierre Shale this species was found in samples between 155 feet below the lower key bentonite and 45 feet above the upper key bentonite.

Material.-About 15 specimens were found.

$\begin{array}{cccc}\text { Locality } & \text { Sample } & \text { Locality } & \text { Sample } \\ & 9-\mathrm{S} & 27 \mathrm{~A} \ldots \ldots & 2-\mathrm{S} \\ & 16-\mathrm{S} & & 3-\mathrm{X} \\ 4 \ldots & 5-\mathrm{X} & 41 \ldots \ldots & 1-\mathrm{S} \\ 7 \ldots \ldots & 3-\mathrm{VR} & & 5-\mathrm{X}\end{array}$

Nodosaria cf. N. aspera Reuss

Plate 6, figure 17

Remarks.-Three specimens are included under this designation, and only one of these is well preserved. They consist of three or four ovoid, inflated, rapidly enlarging, slightly overlapping chambers the walls of 
which are covered by moderately closely spaced delicate spines or spine bases. The aperture is elevated on an elongate, slender, cylindrical neck. Dimensions of the plesiotype, the only well-preserved specimen: length (incomplete), $0.82 \mathrm{~mm}$; breadth, $0.22 \mathrm{~mm}$.

Occurrence.-In California, Nodosaria aspera has been reported from beds of Coniacian (Trujillo, 1960, p. 328) and Campanian (Graham and Clark, 1961, p. 108) ages. In the Gulf Coast Cretaceous deposits, it has been found in beds of Taylor age (Cushman, 1946, p. 72 ), and it has been reported from the Upper Cretaceous of Maryland (Cushman, 1948a, p. 252).

Other reports of $N$. aspera are from Germany, France, Poland, Trinidad, and the U.S.S.R. (Siberia).

In the upper part of the Pierre Shale the specimen from locality 7 came from directly above the lower key bentonite, and those from locality 36 came from within 150 feet below this level.

Material.-Three specimens were found.

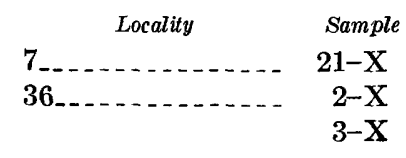

\section{Nodosaria fusula Reuss}

Plate 6, figure 18

Nodosaria fusula Reuss, 1874, Paleontographica, v. 20, pt. 2, p. 82, pl. II $\cdot 20$, fig. 9 .

Remarks.-The test is composed of four or five ovate, inflated, slightly overlapping chambers that increase rapidly and not very regularly in size as added. The ornamentation consists of four well-developed thin, platelike costae which are spaced about $90^{\circ}$ apart and which attach as buttresses to the elongate, slender cylindrical apertural neck. One minor costa lies between each pair of major ones. The costae extend uninterrupted from the base of the test to the top of the final chamber, but only the four major costae extend onto the apertural neck. This species is characterized by its ornamentation, apertural neck, and chamber shape, and the Pierre specimens are typical. Dimensions of the only other complete specimen in addition to the plesiotype: length, $0.36 \mathrm{~mm}$; breadth, $0.10 \mathrm{~mm}$.

Occurrence.-Nodosaria fusula has been reported from beds of Taylor and Austin ages in the Gulf Coast Cretaceous deposits (Cushman, 1946, p. 72), from the Upper Cretaceous of Maryland (Cushman, 1948a, p. 252), from beds of Campanian and Santonian ages on the Arctic slopes of Alaska (Tappan, 1962, p. 173), and from the Cretaceous of Germany.
SHALE, FOX HILLS SANDSTONE, S. DAK.

In the upper part of the Pierre Shale this species occurs from 45 feet above the upper key bentonite to 126 feet below the lower key bentonite.

Material. Fewer than 20 specimens were found.

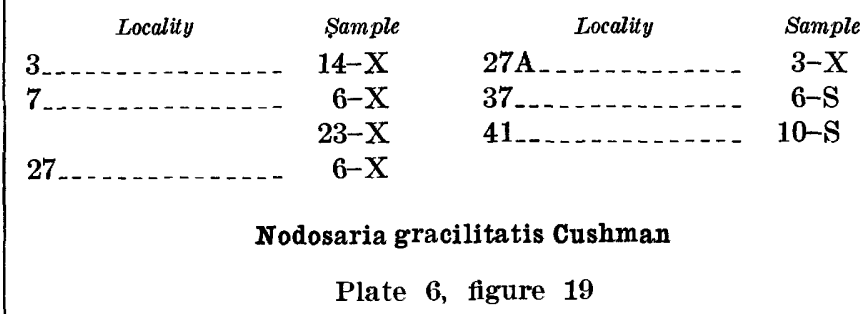

Vodosaria gracilitatis Cushman, 1938, Cushmar Lab. Foram. Research Contr., v. 14, pt. 2, p. 41, pl. 6, figs. 23-26.

Remarks.-The Pierre specimens placed in this species are usually preserved as single chambers, although a few consist of two or three chambers. The chambers are elongate, slender, and fusiform. They are ornamented by about six low, wide, longitudinal costae. These may or may not continue across sutures or across chambers. Several specimens have costae only at the tapering ends of the chambers. Close similarity exists between the holotype of this species and the specimens with costae extending the length of the chamber. The specimens with costae only at the ends of the chambers are probably smooth variants of the more heavily costate forms. Dimensions of a two-chambered fragment of a relatively large specimen: length, $0.89 \mathrm{~mm}$; breadth, $0.16 \mathrm{~mm}$.

Occurrence.-This species has been reported from the lower part of the Taylor Marl of Texas (Cushman, 1946, p. 72) and from the Upper Cretacesus of Maryland (Cushman, 1948a, p. 253).

In the upper part of the Pierre Shale tris species occurs from 21 feet to 126 feet below the lower key bentonite.

Material.-Fewer than 40 specimens were found.

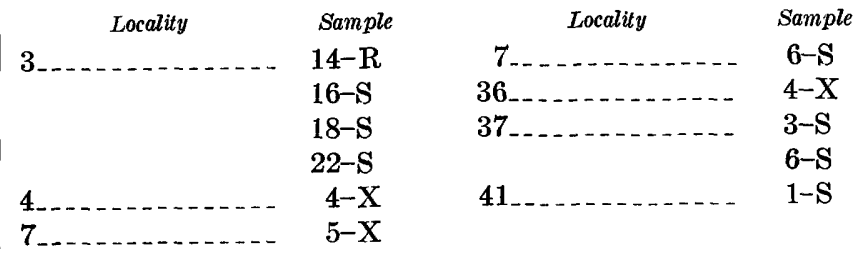

Genus RECTOGLANDULINA Loeblich and Tappan, 1955

Rectoglandulina appressa Loeblich and $T \wedge$ ppan

Plate 7, figures 1a, b; 2a, b

Rectoglandulina appressa Loelolich and Tappan, 1955, Smithsonian Misc. Colln., v. 126, no. 3, p. 4, pl. 1, figs. 1-4.

Remarks.-The specimens from the upp $\rightarrow$ part of the Pierre Shale closely resemble the smaller, more fusiform paratypes of Rectoglandulina appressa. O ve such para- 
type is that illustrated in figure 1 of Loeblich and Tappan $(1955$, pl. 1). Pseudoglandulina acuta LeRoy, from the Miocene or Pliocene of the Netherlands East Indies, appears to be closely similar to $R$. appressa, judging from the type description and figures. No specimens of $P$. acuta were available for comparison. Dimensions of average-sized specimens: length, about $0.2 \mathrm{~mm}$; breadth, 0.1 to $0.15 \mathrm{~mm}$.

Occurrence.-Loeblich and Tappan $(1955$, p. 4, 5) reported this species from the Ozan Formation and Annona Chalk of Arkansas and the Corsicana Marl and Taylor Marl of Texas. It has not been reported elsewhere.

In the upper part of the Pierre Shale Rectoglandulina appressa is a rare species in samples from immediately below the lower key bentonite to 69 feet below this level.

Material.-Twelve specimens were found.

$\begin{array}{cccc}\text { Locality } & \text { Sample } & \text { Locality } & \text { Sample } \\ 3 \ldots \ldots & 22-\mathrm{S} & 37 \ldots \ldots-\mathrm{X} \\ \mathbf{2} & 23-\mathrm{S} & 39 \ldots \ldots & 1-\mathrm{X} \\ & 5-\mathrm{X} & 41 \ldots \ldots \ldots & 1-\mathrm{S}\end{array}$

Genus CITHARINA d'Orbigny, 1839, emend. Marie, 1938 Citharina sp. A

Plate 7, figure 3

Test elongate, moderately compressed, dorsal edge straight, ventral edge slightly convex, pointed at both ends; chambers very few, three in largest specimen, initial chamber long, slender, fusiform, circular in cross section; later chambers similar except not as long, pointed at apertural end and rounded at base, slightly sinuous; second chamber reaches back to about the middle of the initial chamber, third chamber reaches nearly to the base of the second; sutures fairly distinct, slightly depressed, sinuous; wall ornamented by a few thin but prominent costae, these are vertical or nearly so, even across the slightly oblique later" chambers, they may or may not continue across sutures; aperture apparently atop the thin, cylindrical drawn-out tip of the final chamber, details not preserved. Dimensions of the plesiotype, the only complete specimen: length, 0.76 $\mathrm{mm}$; breadth, $0.08 \mathrm{~mm}$; thickness, $0.06 \mathrm{~mm}$.

Remarks.-The Pierre specimens do not appear to belong in any described species of Taginutina or $\mathrm{Cith}$ arina. They are placed in the genus $C$ itharina on the basis of the rectilinear grouping of the chambers, the compression of the test, the elongation and obliquity of the chambers, the presence of fine longitudinal costae, and the straightness of the dorsal margin. Marie (1938, p. 93), in his emendation of the genus Citharina, used most of these characteristics to distinguish Citharina from Vaginulina and Planularia. The Pierre specimens are perhaps not as strongly compressed as specimens of most species of Citharina, and the apertural details could not be observed, but in the other diagnostic features they correspond well with Citharina as emended by Marie.

Occurrence.-Citharina sp. $\mathbf{A}$ is present in a number of samples in the upper part of the Pierre Shale from 43 feet above the upper key bentonite to 126 feet below the lower key bentonite but is never represented by more than a few specimens in any one sample.

Material.-Fewer than 40 specimens were found, and most are poorly preserved.

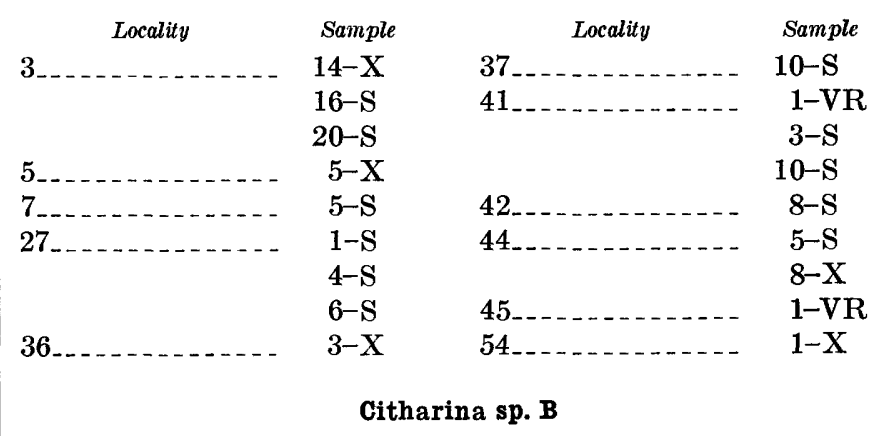

Plate 7, figures $4 a, b$

Test strongly compressed, initial end acute, dorsal margin straight, bicarinate, ventral margin convex, also bicarinate, greatest breadth near the base; chambers distinct, seven in each of two complete specimens, not inflated, increase markedly in length as added, with a moderate increase in width and slight increase in thickness, the bases of all but the initial chamber lie along an imaginary line which lies nearly perpendicular to the straight side of the test; sutures distinct, curved, moderately to quite limbate; wall ornamented with a very few weak vertical costations in the lower and middle parts of the test; aperture terminal, at the apex of the thin, drawn-out final chamber, an irregular opening, possibly slightly radiate. Dimensions of the only specimen in addition to the plesiotype : length, $0.95 \mathrm{~mm}$; breadth, $0.20 \mathrm{~mm}$; thickness, $0.04 \mathrm{~mm}$.

Remarks.-These specimens do not appear to belong in any described species of either Vaginulina or $C$ itharina. V. barcoensis Cushman and Hedberg is similar but differs in being much wider and in having more chambers and more longitudinal costae.

The Pierre specimens definitely belong in the genus Citharina, as emended by Marie (1938, p. 93), on the basis of their total morphology, but they do not correspond to Marie's emended description in one respect. According to Marie, the genus Citharina is distinguished from the genus Traginulina in having very inclined, narrow, elongate chambers which are not car- 
inate at the peripheries. The Pierre specimens have chambers of this character, but the chambers are carinate at their lateral peripheries. In my opinion the presence of absence of carinae may well be of specific importance within the genus Citharina but should not be considered to be of generic importance.

Occurrence.-Citharina sp. B was found in three sections along the Moreau River and occurs 36 to 115 feet below the lower key bentonite.

Material.-Fewer than 10 specimens were found.

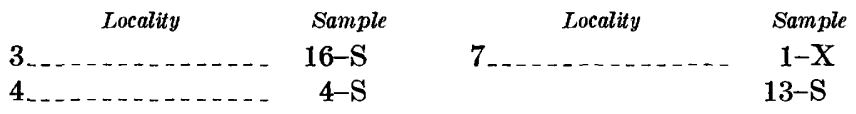

\section{Genus Palmula Lea, 1833}

Palmula primitiva Cushman Plate 7, figure 5

Palmula primitiva Cushman, 1939, Cushman Lab. Foram. Research Contr., v. 15, pt. 4, p. 91, pl. 16, figs. 4, 5 .

Remarks.-The single specimen referred to this species is well enough preserved to show the early coiled part, chevron-shaped adult chambers, and limbate sutures flush with the surface. The specimen does not preserve the fine striae noted by Cushman as being present on the holotype, but these striae are also not preserved on the paratype of the species, an indication that they are either easily destroyed or are not always developed. The distinctiveness of this species compensates for the scarcity of specimens and makes identification possible. Dimensions of the plesiotype: length, $0.47 \mathrm{~mm}$; breadth, $0.22 \mathrm{~mm}$; thickness, $0.12 \mathrm{~mm}$.

Occurrence.-Cushman (1946, p. 84) reported Palmula primitiva from beds of late Taylor age in the Gulf Coast deposits and indicated that this species should be a good index fossil for beds of this age. The only other North American report of this species is from the Upper Cretaceous of California (Bandy, 1951, p. 495). It has also been reported from the Cretaceous of Colombia and Poland.

The single specimen recovered from the upper part of the Pierre Shale comes from 115 feet below the lower key bentonite.

Material.-One specimen was found.

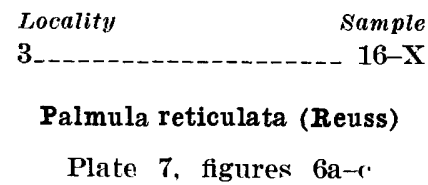

Plate 7, figures 6a-r.

Flabellina reticulata Reuss, 1851, Haidinger's Naturw. Abh., v. 4, pt. 1, p. 30, pl. 1, fig. 22.

Frondicularia reticulata (Reuss). Bagg, 1898, U.S. Geol. Survey Bull. 88, p. 50, pl. 3, fig. 6 .

Palmula reticulata (Reuss). Cushman, 1940, Foraminifera, [3d ed.] pl. 20, fig. 9.
Remarks.--Only a single specimen of this distinctively ornamented species was found. It differs from the figures given by Cushman (1946, pl. 31, figs. 1-6) only in test outline, which Cushman listed as a variable character. Comparison with the specimens of this species in the U.S. National Museum collections reveals that the reticulations in the Pierre specimen are wider apart and more elevated than in most specimens in the collection; the chambers are also slightly wider. "The specimen is exactly similar to one of the five topotypes of this species in the U.S. National Museum collections and is very closely similar to the other four. Dimensions of the specimen : length, $0.94 \mathrm{~mm}$; braadth, 0.56 $\mathrm{mm}$; thickness, $0.12 \mathrm{~mm}$.

Occurrence.-Palmula reticulata has been reported from beds of Taylor and Navarro ages in the Gulf Coast deposits, as summarized by Cushman (1946, p. 84). The only other North American report of the species is by Olsson $(1960$, p. 22$)$ from bec's of latest Cretaceous and possibly earliest Tertiary ages in New Jersey. The species has also been reported frc m the Cretaceous of Denmark, the Dutch East Indies, Israel, and the U.S.S.R.

The specimen found in the upper part of the Pierre Shale comes from a sample the exact position of which is unknown, but which is almost certainly within 150 feet below the lower key bentonite.

Material.-One specimen was found.

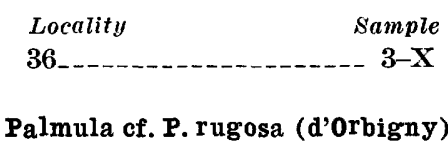

Plate 7 , figure 7

Remarks.-Only the lower third of a single specimen was found. This fragment exhibits an early coiled part followed by chevron-shaped chambers. The sutures are raised and sharp, and the surface between them is covered with short round papillae. These fatures are all characteristic of Palmula rugosa, but kocause test shape, aperture, and later chambers cannot bo observed, the specimen cannot be placed in this species with certainty. Dimension of the specimen : length, incomplete; breadth, $0.50 \mathrm{~mm}$; thickness, $0.15 \mathrm{~mm}$.

Occurrence.-Palmula rugosa has been reported from beds of Austin, Taylor, and Navarro ages in the Gulf Coast Cretaceous deposits (Cushman, 1946, p. 83). The only other reported North American occurrence is from the Cretaceous of Maryland (Cushman, 1948a, p. 254). This species has also been reported from the Cretaceous of New Zealand, the Netherlands, Israel, and Poland.

The single specimen from the upper part of the Pierre Shale, tentatively assigned to $P$. mugosa, comes from within 150 feet below the lower key bentonite. 
Material.-One specimen was found.

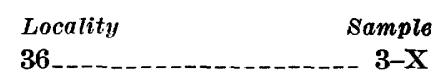

\section{Genus FRONDICULARIA DeFrance, 1826}

Frondicularia archiaciana d'orbigny

Plate 7, figures $8 \mathrm{a}, \mathrm{b}$

Frondicularia archiaciana d'Orbigny, 1840, Soc. géol. France Mém., 1st ser., v. 4. p. 20, pl. 1, figs. 34-36.

Remarles.-Only 11 specimens referable to this distinctive species were found. They are characterized by the wide, truncate periphery, bulbous initial chamber with basal spine and heavy costae, and slender, compressed, gently tapering test. Most specimens have characteristic raised, limbate, slightly curved sutures, but one specimen has slightly inflated chambers and slightly depressed sutures. Dimensions of a comparatively small megalospheric specimen of two chambers and proloculus: length, $1.02 \mathrm{~mm}$; breadth, $0.31 \mathrm{~mm}$; thickness (measured above the bulbous proloculus), $0.18 \mathrm{~mm}$.

Occurrence.-This species has been reported from a number of formations of Taylor and Navarro ages in the Gulf Coast deposits (Cushman, 1946, p. 91) and from the Cretaceous of New Jersey (Jennings, 1936, p. 22), Maryland (Cushman, 1948a, p. 255), and California (Cushman and Campbell, 1935, p. 70; Bandy, 1951, p. 496). The only report of Frondicularia archiaciana from the western interior of the United States is from the Hilliard Shale of Campanian-Santonian age in Wyoming (Gauger, in Jones, 1953, p. 72, 73).

In the upper part of the Pierre Shale this species occurs 103 to 126 feet below the lower key bentonite.

Material.-11 specimens.

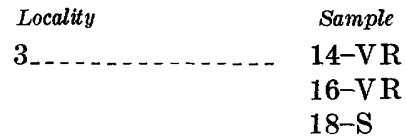

Genus LAGENA Walker and Jacob, 1789

Lagena sp. aff. L. quadralata Brady

Plate 7, figure 9

Remarks. - A single specimen which bears close resemblance to Brady's species was found. It has four wide, equidistant, tubulated wings or alate costae which widen both at the top and base of the chamber. At the top of the chamber the wings attach at the base of the very elongate apertural neck, and at the bottom of the chamber they join in a thickening at the longitudinal axis of the chamber. The chamber itself is globular and, unlike Brady's species, has a finely hispid surface rather than a longitudinally weakly striate surface. Th? specimen is $0.28 \mathrm{~mm}$ high and $0.08 \mathrm{~mm}$ wide.

Several other specimens, only one of which is well preserved, may belong in the same species, although they differ in having more than four wings. The scarcit:r of specimens from the Pierre samples and the wellknown variability of the Lagenidae contribute to the difficulty of assigning a name to the Pierre specimens. The species which seems to me to be most similar in morphology to the Pierre specimens is Lagena quadrc. lata Brady. This judgment is based on the publisher type description and figures; no comparative material was seen. The fact that the chamber surface in $L$. quadralata is striate rather than hispid and the fact the.t L. quadralata is a Recent and Tertiary species lead me to use this species name only as a means of comparing the morphology of the Pierre specimens with a known species rather than as an expression of inferred genetic relationship.

Occurrence.-Lagena quadralata was first described from Recent seas (Brady, 1881, p. 62) and since then has been reported from deposits as old as Eocene. It has never been described from the Cretaceous.

The Pierre specimens were found in samples between the base of the upper key bentonite and 103 feet below the lower key bentonite.

Material.-Fewer than 10 specimens were found.

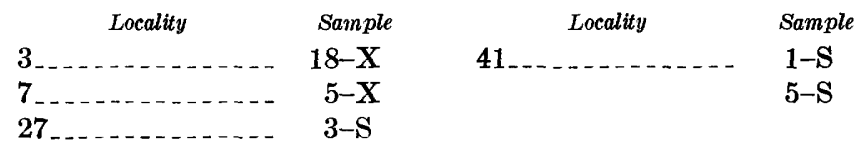

Lagena sulcata (Walker and Jacob) semiinterrupta W. Berry

Plate 7, figures $10 \mathrm{a}, \mathrm{b}$

Lagena sulcata (Walker and Jacob) var. semiinterrupta $V$. Berry, 1929, in Berry and Kelley, U.S. Natl. Mus. Proc., v. 76, art. 19, p. 5, pl. 3, fig. 19.

Lagena sulcata semiinterrupta W. Berry. Olsson, 1960, Jour. Paleontology, v. 34, no. 1, p. 23, pl. 3, fig. 22.

Remarks.-The numerous strong costae originate at a small ring of shell material at the base of the test, which seems to be the point of attachment of a basal spine. Most of the specimens have a small costate protrusion atop the spherical chamber from which tra fairly long, smooth apertural neck arises. Several spe?imens have only three or four widened and very delicate costae extending onto this protrusion. The holotype and other specimens of this subspecies in the U.S. National Museum collections are quite similar to tra Pierre specimens. Dimensions of average-sized specimens: length, 0.15 to $0.2 \mathrm{~mm}$; breadth, about $0.1 \mathrm{~mm}$.

Occurrence.-Cushman (1946, p. 94) reported this subspecies from deposits of Navarro age in Tennesses. 
It has also been reported from the Upper Cretaceous of Maryland (Cushman, 1948a, p. 256) and New Jersey (Jennings, 1936, p. 23; Olsson, 1960, p. 23).

In the upper part of the Pierre Shale this subspecies occurs from 12 feet above the upper key bentonite to 103 feet below the lower key bentonite.

Material.-Fewer than 75 specimens were found.

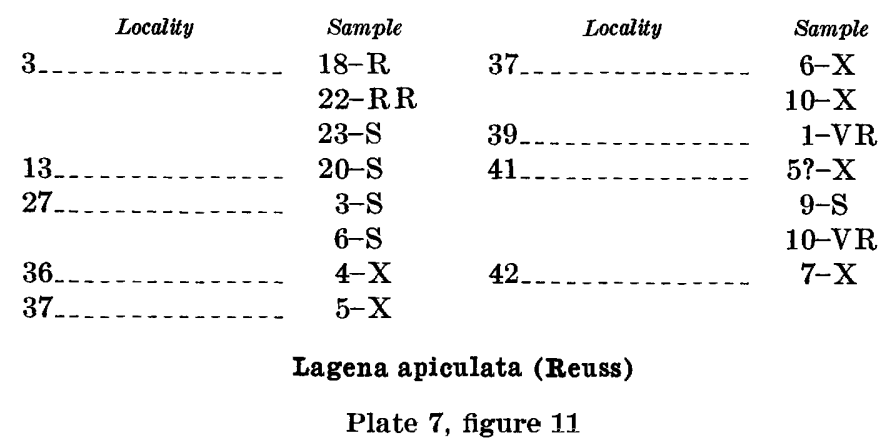

Oolina apiculata Reuss, 1850, Haidinger's Naturw. Abh., v. 4, p. 22, pl. 1, fig. 1.

Lagena apiculata (Reuss). Reuss, 1861, Akad. Wiss., Wien. Sitzungsber. v. 44, pt. 1, p. 325, (1862).

Test single chambered, small, pyriform, circular in apertural view; wall smooth, opaque, usually smooth and rounded at the base, but one specimen with a short basal spine; aperture at the narrow end of the test, slightly produced, a series of radially arranged slits, occasionally with a small rounded central opening atop a solid transparent cone of shell material which composes as much as one-fifth the length of the test and which is penetrated by a slender tube connecting the aperture to the interior; tube does not continue free into the interior. Dimensions of average-sized specimens: height, about $0.2 \mathrm{~mm}$; breadth, 0.1 to $0.15 \mathrm{~mm}$.

Remarks.-The type specimen of this species, as described by Reuss, has a short basal spine. One of the Pierre specimens has such a spine and appears to be identical with Reuss' figured specimen. The other Pierre specimens from the same, as well as different, samples lack a basal spine but in other respects are similar to the specimen bearing the basal spine. A small suite of specimens in the U.S. National Museum collections labeled Lagena apiculata (Reuss), from the Lizard Springs Marl, Trinidad (Cushman colln. 46656), includes several specimens lacking basal spines which are closely similar in form to the majority of the Pierre specimens, though slightly larger.

The single spine-bearing specimen from the upper part of the Pierre is to be placed definitely in L. apiculata (Reuss). The spineless specimens which occur with it, and similar spineless specimens from other samples, are also placed in this species because they are mor- phologically similar in all other respects to the spinebearing specimen.

Occurrence.-Lagena apiculata has been reported from beds of Navarro and Taylor ages in the Gulf Coast Upper Cretaceous (Cushman, 1946, p. 94), from the Upper Cretaceous of Maryland (Cushman, 1948a, p. 256), and from the Lower Cretaceous of Texas, Oklahoma, and Alaska. This species has also been reported from the Cretaceous of Germany, Austria, Hungary, Czechoslovakia, Poland, Switzerland, the Netherlands, Sweden, France, England, Egypt, Mexico, Venezuela, and Australia.

L. apiculata occurs 51 to 165 feet below the lower key bentonite in the upper part of the Pierre Shale.

Material.-About 10 specimens were found.

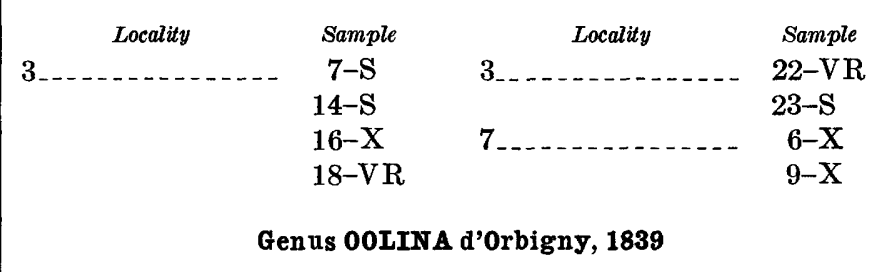

Oolina obeliscata Mello, n. sp.

Plate 1, figures 5a, b; plate 7, figures 12, 13

Lagena vulgaris Williamson. Cushman, 1931, Jour. Paleontology, v. 5, no. 4, p. 308, pl. 35, fig. 11 (not of Williamson).

Test spherical, ovate or elongate fusoid, with a small basal spine or a vestige thereof; wall surface not glassy, smooth to moderately hispid, translucent in well-preserved specimens; aperture a round opening at the end of an elongate cylindrical unornamented tube, with a slightly thickened lip; a straight entosolenian tube extends into the chamber along the axis of elongation from the base of the apertural neck to as much as twothirds the length of the test. Dimensions of averagesized specimens; height, 0.15 to $0.2 \mathrm{~mm}$; breadth, 0.1 to $0.15 \mathrm{~mm}$.

Remarks.-The variation in wall rugosity may be due to preservational factors rather than orginal variability. The small protuberances are more easily dissolved than the wall proper and thus may have been lost since the test was abandoned. The short delicate basal spine has been broken off in some specimens and a small hole at the base of the test is the result. Several specimens have neither a spine nor a basal hole, and presumably in these specimens the spine was broken or dissolved off flush with the wall of the test. Alternatively, some of the tests may have lacked spines originally, although in other respects they exactly resemble the specimens with spines. The elongate apertural neck is commonly broken at various heights above the top of the test, but in a few specimens the round apertural opening is slightly thick- 
ened, and it is presumed that in these specimens the apertural neck is complete. The entosolenian tube extends only a very short distance into the chamber in most specimens, and in a few it apparently has been broken or dissolved off flush with the inner surface of the test. However, several specimens that are filled with a clear noncalcareous mineral, presumably silica, have tubes preserved that extend one-half to two-thirds the length of the test. The end of the tube could not be closely observed, but it does not seem to widen or flatten out. It was not possible to determine whether or not the tube continues as a discrete inner cylinder within the external apertural neck, but judging from the narrowness of the apertural neck and the nearly equal diameter of the entosolenian tube, it seems unlikely that this is the case.

The Pierre specimens, considered in the framework of Parr's (1947) classification of the Lagenidae, are placed in the genus Oolina d'Orbigny on the basis of the entosolenian tube. Parr (1947, p. 120) cited several species that have both an apertural neck and entosolenian tube which he believes are probably referable to Ootina. However, it should be pointed out that, to my knowledge at least, the function, the biologic importance, and the history of the development of the entosolenian tube, on which recognition of the genus Oolina is largely based, are not known.

Parr (1947, p. 120) pointed out that "**** it is not unlikely that the Mesozoic species showing the external characters of the genus Lagena include a number in which the entosolenian tube is also present." Some of the Pierre specimens assigned to $O$. obeliscata $\mathrm{n}$. sp. resemble the descriptions and figures of L. laevis (Montagu) var. stavensis Bandy and L. sphaerica Marie, but neither of these taxa are reported to have entosolenian tubes.

L. citriformis Buchner has an internal tube and externally resembles $O$. obeliscata n. sp., except that it lacks an elongate apertural neck. In external features the new species also resembles $L$. mucronata Terquem and Berthelin, and the more hispid specimens resemble L. hispida Reuss, but these species also lack an entosolenian tube. No type specimens of any of the above species were available for comparison.

Occurrence.--Specimens in the U.S. National Museum collections labeled Lagena vulgaris Williamson from the Saratoga Chalk of Saratoga, Ark. (Cushman colln. 15617), and from the Marlbrook Marl of Hempstead County, Ark. (Cushman colln. 41885), belong in the new species. Specimens labeled Lagena cf. $L$. vulgaris from the Mooreville Chalk of the Selma Group near Mooreville, Miss. (Cushman colln. 42407, 42408, and 42464), may also belong in the new species.
In the upper part of the Pierre Shale this species occurs from 111 feet above the upper key bentonite to 126 feet below the lower key bentonite.

The holotype and paratypes of Oolina obeliscata are from locality 27 , sample 6 , and bear the following U.S. National Museum numbers: holotype, USNM 642625; figured paratypes, USNM 642623, 642624; unfigured paratype, USNM 642626.

Material.-150 to 250 specimens were found.

\begin{tabular}{|c|c|c|c|}
\hline Locality & Sample & Locality & Sample \\
\hline \multirow[t]{5}{*}{$3 \ldots$} & $14-\mathrm{S}$ & $27 \ldots \ldots$ & $3-\mathbf{R}$ \\
\hline & 18-RR & & $4-S$ \\
\hline & $20-\mathrm{S}$ & & $6-\mathrm{R}$ \\
\hline & 22-RR & & $7-\mathrm{S}$ \\
\hline & $23-\mathrm{S}$ & & $9-S$ \\
\hline \multirow{2}{*}{4} & $4-X$ & 36 & 2-VR \\
\hline & $5-\mathrm{VR}$ & & $3-\mathrm{S}$ \\
\hline \multirow{2}{*}{5} & $5 ?-\mathrm{X}$ & & $4-V R$ \\
\hline & $8 ?-\mathrm{VR}$ & 37 & $1-V R$ \\
\hline \multirow[t]{10}{*}{7} & $1-X$ & & $3-X$ \\
\hline & $5-X$ & & $5-S$ \\
\hline & $6-X$ & & $6-V R$ \\
\hline & $9-X$ & & $10-\mathrm{X}$ \\
\hline & $11-V R$ & 39 & $1-\mathrm{C}$ \\
\hline & $15-\mathrm{S}$ & 41 & $1-V R$ \\
\hline & $19-\mathrm{S}$ & & $9-\mathrm{R}$ \\
\hline & $21-S$ & & $10-V R$ \\
\hline & $23-V R$ & 42 & 8-S \\
\hline & $25-\mathrm{S}$ & 44 & $5-X$ \\
\hline \multirow[t]{4}{*}{13} & $3-X$ & & $8-X$ \\
\hline & $5-X$ & 45 & $1-\mathrm{VR}$ \\
\hline & $20-S$ & & $3-S$ \\
\hline & $21-X$ & & $7-V R$ \\
\hline \multirow[t]{3}{*}{$20 \ldots$} & $5-\mathrm{R}$ & 49 & $5 ?-\mathrm{X}$ \\
\hline & $11-V R$ & $53 \ldots$ & $11 ?-\mathrm{X}$ \\
\hline & $17-S$ & $54 \ldots$ & $3-X$ \\
\hline 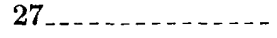 & $1-\mathrm{S}$ & & \\
\hline
\end{tabular}

\section{Genus FISSURINA Reuss, 1850}

Fissurina sp. A

Plate 1, figures 6, 7 ; plate 7 , figures $14 a, b$

Test single chambered, small, moderately compressed, elliptical in outline except truncated at the apertural end at right angles to the axis of elongation, bluntly rounded at the base; wall smooth and rather transparent except for a less transparent slightly raised horseshoe-shaped area on each side, without visible perforations; aperture terminal, narrowly elliptical, about half as broad as the test, thick lipped, with an internal tube which extends approximately to the center of the chamber, end of tube compressed in the plane of compression of the test, extends slightly farther on the flattened sides and thus forms a saddle-shaped opening in the tube; the cloudy horseshoe-shaped areas lie parallel to the periphery of the test and ring the clear central areas except at the apertural end; slightly ele- 
vated ridges mark the peripheral and inner margins of these areas. Dimensions of average-size specimens: height, about $0.15 \mathrm{~mm}$; breadth, 0.1 to $0.15 \mathrm{~mm}$; thickness, about $0.1 \mathrm{~mm}$.

Remarks.-Only seven well preserved specimens of this species were found. They resemble Lagena Tunata Matthes in the presence and shape of the horseshoeshaped areas but differ in having a more truncated upper surface and less compressed test. The specimens are placed in the genus Fissurina on the basis of the moderately compressed test, elongate fissurelike aperture, and entsolenian tube. They do not seem to belong in any previously described species of Fissurina, Entosolenia, or Lagena, but because so few specimens have been found, no new species is erected here to receive them.

A single specimen of this species is reported, also as Fissurina sp. A, from the Cretaceous Monmouth Group of New York (Perlmutter and Todd, 1965, p. 16).

Occurrence.-Specimens were found at only one locality and occurred from the base of the lower key bentonite to 34 feet below this bentonite.

Material.-Seven specimens.

$\begin{array}{cc}\text { Locality } & \text { Sample } \\ 41 & 3-\mathrm{S} \\ & 9-\mathrm{S} \\ 10-\mathrm{S}\end{array}$

\section{Family POLYMORPHINIDAE}

Genus GUTTULINA d'Orbigny, 1826

Guttulina trigonula (Reuss)

Plate 7, figures 15a-d, 16

Polymorphina trigonula Reuss, 1845, Versteinerungen böhmischen Kreideformation, pt. 1, p. 40, pl. 13, fig. 84 .

Guttulina trigonula (Reuss). Cushman and Ozawa, 1930, U.S. Natl. Mus. Proc., V, 77, art. 6, p. 28, pl. 4, fig. 2.

Test teardrop shaped, generally a rounded triangle in outline viewed from the base, subflattened at the base, apertural end slightly drawn out; chambers rounded, inflated, elongate, arranged in a clockwise quinqueloculine series, each succeeding chamber extends back to the base but does not cover all the earlier chambers at the base; the net effect of addition of chambers is the obscuring of all but the earliest parts of the most centrally located chambers, thus making it impossible to deduce the nature of chamber addition without sectioning; sutures slightly if at all depressed, quite distinct on well-preserved specimens; wall smooth, apparently very finely perforate; aperture at the apex of the test, radiate. Dimensions of average-sized specimens: length, about $0.3 \mathrm{~mm}$; breadth, 0.25 to $0.3 \mathrm{~mm}$; thickness, about $0.2 \mathrm{~mm}$.
Remarks.-In side view one side is typicslly flat with only a small part of a previous chamber visible between the two large lateral chambers, whereas the opposite side is quite rounded because of the bulge of the third from the last chamber between the two lateral chambers. Often only these four chambers are visible in side views, but occasionally the edges of one or two ott or chambers may be seen, especially from the bulging side. In basal view the early parts of a variable numb?r of chambers, usually three to five, may be seen.

The upper Pierre specimens are similar to Guttulina problema (d'Orbigny) and G. irregularis (d'Orbigny), but in my judgment they more closely resemble $G$. trigonula (Reuss). The rather close similarity of these three species and the morphologic variability exhibited by the Pierre specimens suggests that the features used to discriminate these species may not be diagnostic.

Occurrence.-Guttulina trigonula has bsen reported from beds of Taylor and Navarro ages in the Gulf Coast deposits (Cushman, 1946, p. 96), from the Upper Cretaceous deposits on Georges Bank (Cushman, 1936, p. 418), and from the Upper Cretaceous of Maryland (Cushman, 1948a, p. 256). This species has also been reported from the Upper Cretaceous of Sweden, Switzerland, Germany, the Netherlands, and Mexico.

In the upper part of the Pierre Shale this species occurs from 36 feet to 126 feet below the lower key bentonite.

Material.-Fewer than 50 specimens were found.

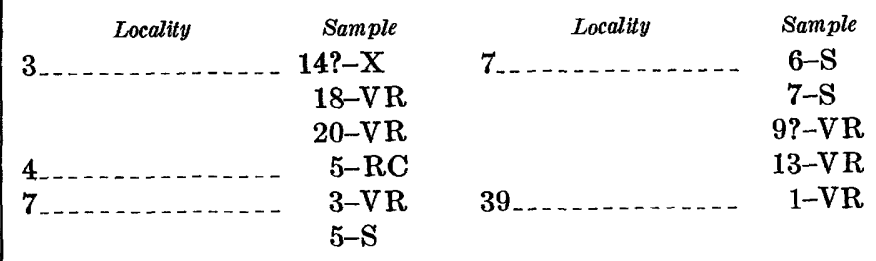

Genus GLOBULINA d'Orbigny, 1839

Globulina lacrima Reuss

Plate 7, figures $17 \mathrm{a}, \mathrm{b}, 18$

Polymorphina (Globulina) lacrima Reuss, 1845 Versteinerungen, Böhmischen Kreideformation. p. 40, pl. 12, fig. 6; pl. 13, fig. 83.

Globulina lacrima Reuss, 1851, Haidinger's Neturw. Abh., v. 4, p. 27 , pl. 4, fig. 9 .

Cushman and Ozawa, 1930, U.S. Natl. Mu Proc., v. 77, art. 6, p. 77, pl. 19. figs. 1, 2 (gives exhaust've synonymy).

Test subglobular to pyriform, nearly circular in transverse section; chambers few, inflated, rounded in outline, arranged triserially; the last two compose nearly all the test in larger specimens; sutc res generally not depressed except slightly in some smaller specimens, difficult to distinguish in larger specimens; wall 
smooth, translucent in better specimens, apparently very finely perforate; aperture apical, radiate, produced. Dimensions of average-sized specimens: length, about $0.3 \mathrm{~mm}$; breadth, 0.2 to $0.25 \mathrm{~mm}$; thickness, 0.15 to 0.2 mm.

Remark:s.--Externally some specimens of this species resemble species of Guttulina. Sections reveal that chambers are arranged $90^{\circ}$ to $180^{\circ}$ apart, unlike the arrangement in Guttulina.

Cushman and Ozawa (1930, p. 77), in their monograph on the family Polymorphinidae, state that in Globulina lacrima "the apertural end is definitely produced. The Cretaceous specimens of both Europe and America that we have examined are constant in this character." All specimens from the upper part of the Pierre Shale have this produced aperture and correspond quite well to most of the specimens of G. lacrima in the U.S. National Museum collections.

A single specimen of the G. lacrima var. horrida type was obtained from locality 3 , sample 23 . Its chambers are covered with small low protuberances which probably were the basal attachments of small spines, of which only a few remain. The final chamber is low and has three or four broken fistulose projections extending from it.

Occurrence.-Globulina lacrima has been reported from the Niobrara Formation, of Coniacian-Santonian age, of Nebraska (Loetterle, 1937, p. 31) and North Dakota (Grunseth, 1955, p. 125). In the Gulf Coast Upper Cretaceous it has been reported from beds of Austin, Taylor, and Navarro ages (Cushman, 1946, p. 96). It has also been reported from the Cretaceous greensand of New Jersey (Reuss, 1861, p. 338) and from the Georges Bank canyons (Cushman, 1936, p. 418). $G$. lacrima has also been reported from the Cretaceous of Germany, Peru, Austria, the Netherlands, the U.S.S.R., Belgium, Venezuela, Angola, and Japan.

The Pierre specimens of $G$. lacrima were found in samples 72 to 126 feet below the lower key bentonite, except for a single specimen obtained 6 inches below the upper key bentonite at locality 5 .

Material.-Fewer than 25 specimens were found.

$\begin{array}{clcc}\text { Locality } & \text { Sample } & \text { Locality } & \text { Sample } \\ & 14-\mathrm{VR} & 3 \ldots \ldots & 23-\mathrm{X} \\ & 16-\mathrm{X} & 4 \ldots \ldots & 4-\mathrm{R} \\ & 18-\mathrm{X} & 5 \ldots \ldots & \end{array}$

\section{Genus PYRULINA d'Orbigny, 1839}

Pyrulina cylindroides (Roemer)

Plate 8 , figures 1a-c

Polymorphina cylindroides Roemer, 1838, Neues Jahrb., p. 385, pl. 3, fig. 26
Pyrulina cylindroides (Roemer). Cushman and Ozawa, 1930, U.S. Natl. Mus. Proc., v. 77, art. 6, p. 56, pl. 14, figs. 1-5.

Remarks.-The redescription of Pyrulina cylindroides given by Cushman and Ozawa $(1930$, p. 56$)$ adequately describes the Pierre specimens, and their figures (pl. 14, figs. 1-5) cover the range of variation exhibited by these specimens. Good agreement is also found between the Pierre specimens and most of the specimens labeled $P$. cylindroides in the U.S. National Museum collections. No specimens with a branching or fistulose final chamber were found. Dimensions of average-sized specimens: length, 0.25 to $0.3 \mathrm{~mm}$; breadth, 0.1 to 0.15 $\mathrm{mm}$; thickness, about $0.1 \mathrm{~mm}$.

Occurrence.-Pyrulina cylindroides has been reported from beds of Taylor and Navarro ages in the Gulf Coast deposits (Cushman, 1946, p. 97), from the Upper Cretaceous of Maryland (Cushman, 1948a, p. 257), and from the Lower Cretaceous of Texas (Bullard, 1953, p. 343; Tappan, 1940, p. 114). This species has also been reported from the Cretaceous of the U.S.S.R., Germany, Switzerland, the Netherlands, and Australia.

In the upper part of the Pierre Shale, $P$. cylindroides occurs from 16 feet above the upper key bentonite to 126 feet below the lower key bentonite.

Material.-Fewer than 20 specimens were found.

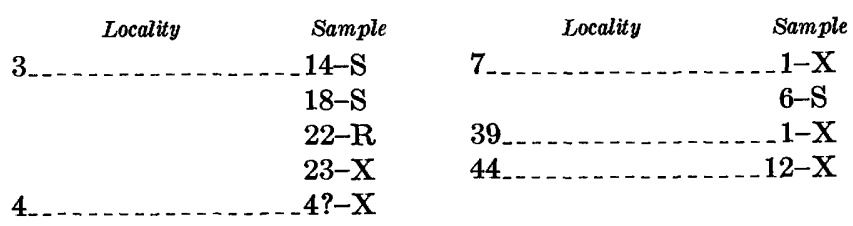

Genus RAMULINA Rupert Jones, 1875

Ramulina cf. R. muricatina Loeblich and Tappan

Plate 8, figure 3

Remarks.-All the Pierre specimens are broken tubular, branched pieces that are clothed with rather long clear spines or the bases for these spines. Apertures, when preserved, are simple round openings at the produced and constricted ends of the branches. Dimensions of a typical fragment: length (incomplete), $0.70 \mathrm{~mm}$; breadth, $0.18 \mathrm{~mm}$.

Ramulina muricatina Loeblich and Tappen (Loeblich and Tappan, 1949, p. 261, pl. 50, figs. 5, 6) is a name erected to replace the name $R$. aculeata Wright, an invalid designation which had been used by various authors (see synonymy in Loeblich and Tappan, 1949, p. 261).

Occurrence.-The name Ramulina muricatina was first used for specimens from the Walnut Clay, of Albian age, from Texas and Oklahoma. According to the synonymy given by Loeblich and Tappan (1949, 
p. 261), the same species has been recorded as $R$. aculeata Wright from the Cretaceous of Germany, Sweden, England, and France and from the Duck Creek Formation of Albian age in Texas (Tappan, 1943, p. 506, pl. 81, fig. $\boldsymbol{\tau}$ ). Since the erection of $R$. muricatina, this species has been reported from the Lower Cretaceous of the Netherlands, Germany, and Poland, in addition to the type American occurrence.

In the upper part of the Pierre Shale, the specimens here placed tentatively in $R$. muricatina occur from 12 feet above the upper key bentonite to 115 feet below the lower key bentonite.

Material.-Dpecimens are not very abundant but are found in a number of samples. Fewer than 75 were found.
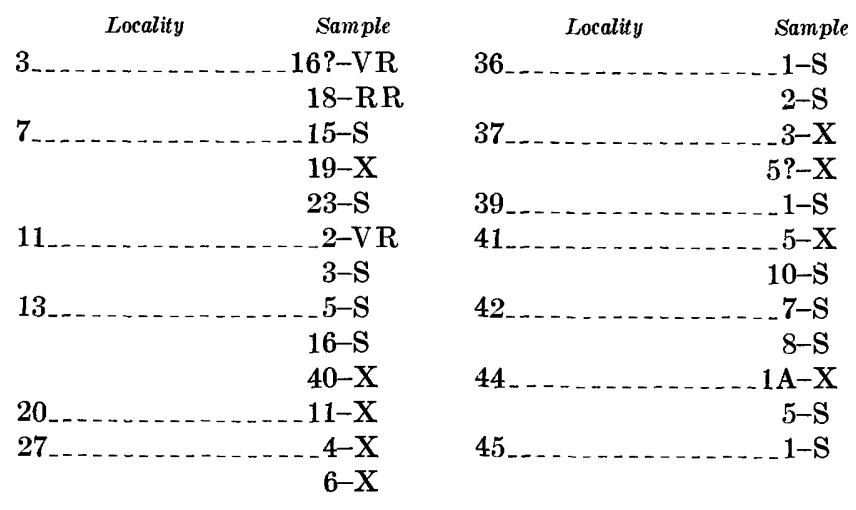

Ramulina sp. A

Plate 8, figures 2a, b

Remarks.-A few incomplete specimens were found which seem quite distinct from all previously described species of Ramutina. The specimens are composed of one or two cylindrical, fairly stout, slightly elongate chambers, the surfaces of which are covered by irregular welts and knobs. These welts and knobs, considerably stouter and more protruding than spine bases, show no sign of having served as such. The aperture is a simple round opening surrounded by a thick lip and located at the center of the end of the chamber. The combination of cylindrical shape, knobby surfaces, and slightly produced ringed aperture distinguishes this species from other species of Ramulina. A new species is not erected because of the incomplete nature of the specimens at hand and because so few specimens were found that a clear conception of the variability of the species could not be formed. Dimensions of an average-sized onechambered fragment: height (incomplete), $0.30 \mathrm{~mm}$; breadth, $0.24 \mathrm{~mm}$.

Occurrence.-The specimens occur from 47 feet above the upper key bentonite to 45 feet below the lower key bentonite.
Material.-Fewer than 20 specimens were found.

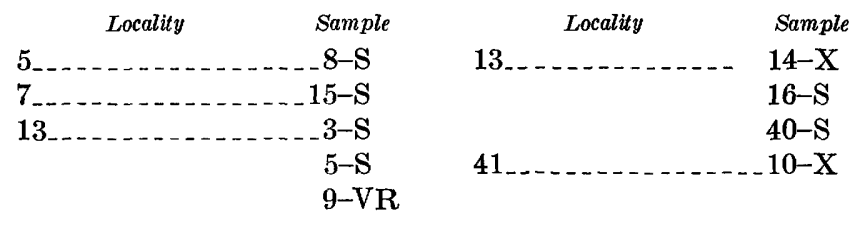

Family HETEROHELICIDAE

Genus HETEROHELIX Ehrenberg, 1841

Heterohelix globulosa (Ehrenberg)

Plate 8, figures 5a, b

Textularia globulosa Ehrenberg, 1834, Kgl. Preuss. Akad. Wiss. Abh., p. 135, pl. 4, fig. 4B.

Gümbelina globulosa (Ehrenberg). Egger, 1899, Kgl. Bayer. Akad. Wiss. Math.-naturw. Abt., Abh., Kl. 2, v. 21, pt. 1, p. 32 , pl. 14, fig. 43.

Heterohelix globulosa (Ehrenberg). Montanaro-Gallitelli, 1957, U.S. Natl. Mus. Bull. 215, p. 138, pl. 31, figs. 12-15.

Test biserial, tapers rather rapidly, greatest breadth toward apertural end, greatest width across the last pair of chambers, 11/4 to 2 times as long as broad; chambers inflated, increase more rapidly in size toward the apertural end, nearly spherical, slightly to moderately overlapping; sutures distinct, depressed, not limbate, wall smooth except for the tops of the final chambers where distinct rugosities are present, finely perforate, in some specimens perforations form very faint and nonpersistent longitudinal markings; aperture broad, low to moderately arched, with a thickened rim above. Dimensions of average-sized specimens: length, 0.25 to $0.3 \mathrm{~mm}$; breadth, about $0.2 \mathrm{~mm}$; thickness, 0.1 to $0.15 \mathrm{~mm}$.

Remarks.-In most specimens a disruption in the regular enlargement of the chambers occurs after the first four or five pairs of chambers. At this stage there is a marked increase in chamber diameter, after which increase is again regular. Very few specimens exhibit an initial coiled stage. In most, the early part is either obscure or clearly biserial. A field of very small, closely spaced spines is atop each of the last two chambers in well-preserved specimens. A greater proportion of the upper surface of the penultimate chamber is covered by them, which would seem to indicate that the living animal added more spines to the already existing field atop the penultimate chamber as well as depositing spines atop the final chamber. These spinose areas are completely overlapped by succeeding chambers. The papillate area about the aperture in species of the Amphisteginidae, as noted by Cushman (1948b, p. 300), may be analogous in mode of origin and in function, although this function is not known. 
Some specimens have very faint striations on the later chambers, and several specimens have them throughout. These striations, which parallel the contours of the chambers, are almost always considerably finer and less noticeable than those on Heterohelix striata, the species these specimens otherwise closely resemble.

Occurrence.-Heterohelix globulosa is one of the most common species of Upper Cretaceous Foraminifera, though most references to it have been made under the generic name Guembelina. It has been reported from the Niobrara Formation of Wyoming (Carman, 1929, p. 312; Shaw, 1953, pl. 1, figs. 19-21), South Dakota (Bolin, 1952, p. 37), and North Dakota (Grunseth, 1955, p. 124) ; from the Niobrara and Greenhorn Formations of South Dakota (Anderson, 1930, p. 3); from the Niobrara and Pierre Formations of South Dakota (Applin, 1933, p. 219) and of Nebraska, Kansas, and South Dakota (Loetterle, 1937, p. 34) ; from the Niobrara, Carlile, Greenhorn, and Graneros Formations (Morrow, 1934, p. 194) ; from the Hilliard Shale of Wyoming (Gauger, in Jones, 1953, p. 77) ; from the Frontier Formation of Montana (Young, 1951, p. 63) ; from the Lloydminster Shale in Alberta (Nauss, 1947, p. 332 (list) ) ; from the Kaskapau Formation of Alberta and British Columbia (Stelck and Wall, 1954, p. 22); from the Favel Formation and the Boyne Member of the Vermilion Formation of Saskatchewan and British Columbia (Wickenden, 1945, p. 33, 42 (lists)); and from the Seabee Formation of Alaska (Tappan, 1962, p. 196). According to the summary given by Cushman (1946, p. 106), H. globulosa has been found in beds of Navarro and Taylor ages in the Gulf Coast Cretaceous deposits. Other United States occurrences are from the Mt. Laurel and Navesink Formations of New Jersey (Jennings, 1936, p. 27), the Georges Bank canyon (Cushman, 1936, p. 418), two wells in Maryland (Cushman, 1948a, p. 258, 267), and the Coniacian of California (Trujillo, 1960, p. 344; Graham, 1962, p. 105). The species has also been reported from Cretaceous deposits in Germany, Australia, New Zealand, Mexico, Czechoslovakia, France, Angola, Cuba, Colombia, Indonesia, the Spanish Sahara, the U.S.S.R., England, the Netherlands, Venezuela, Poland, Egypt, Israel, Peru, Ireland, and Italy.

In the upper part of the Pierre Shale $H$. globulosa occurs from 82 feet above the upper key bentonite to 156 feet below the lower key bentonite. This species is one of the most abundant in the Pierre samples.

Material.-Many thousands of specimens were found. Some very calcareous shale layers are in large part composed of tests of this species.

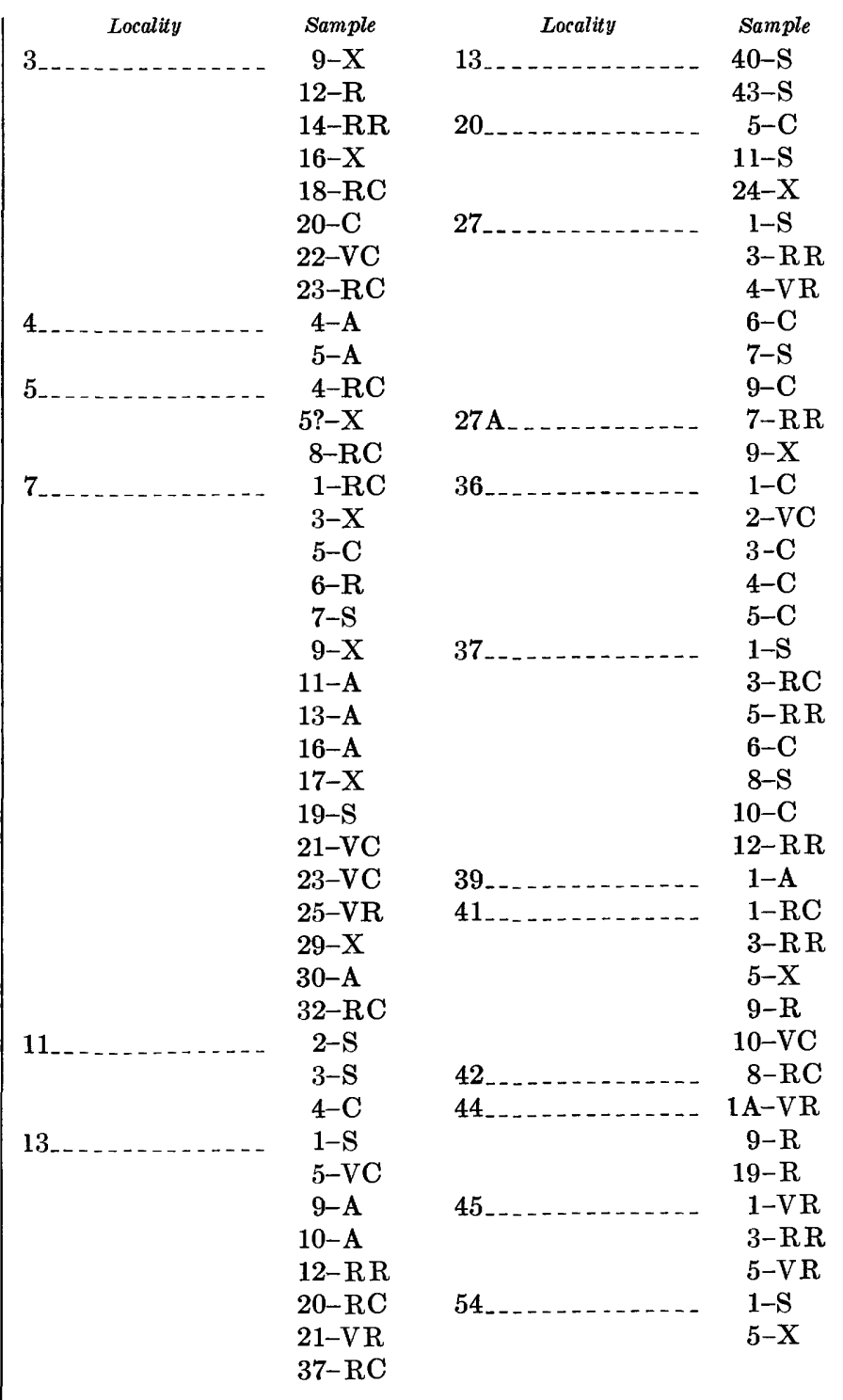

Heterohelix pulchra (Brotzen)

Plate 8, figures $4 a, b$

Gümbelina pulchra Brotzen, 1936, Sveriges geol. undersökning: Årsb., ser. C, no. 396, v. 30, p. 121, pl. 9, figs. 2a, b, 3a, b. Gïmbclina pscudotessera Cushman, 1938, Cushman Lab. Foram. Research Contr., v. 14, pt. 1, p. 14, pl. 2, figs. 19-21.

Heterohelix pulchra (Brotzen). Montanaro-Gallitelli, 1957, U.S Natl. Mus. Bull. 215, p. 137, pl. 31, fig. 20.

Remarks.-This species, as exemplified by the Pierre Specimens, differs from Heterohelix globulosa (Ehrenberg), with which it is almost always associated in the Pierre samples, in that the test is more compressed in the biserial plane because the chambers are more elongate in this plane; each of the last few chambers of the larger specimens overlaps the preceding chamber on the opposite side of the median line, the overlap giving 
FORAMINIFERA, STRATIGRAPHY, PIERRE SHALE, FOX HILLS SANDSTONE, S. DAK.

a distinct sinuousity to the median suture, and the angle of addition of the later chambers with respect to the median line is less than the nearly perpendicular angle of addition in $H$. globulosa.

These specimens have rugosities atop the final pair of chambers, as do specimens of $H$. globulosa, and in a few specimens the final chambers tend to become globular, similar to those in $H$. globulosa. The aperture is only moderately arched but takes up nearly all the low apertural face.

A paratype of Heterohelix pulchra (Cushman colln. 24391), though not too well preserved, closely resembles the Pierre specimens. The holotype of Guembelina pseudotessera Cushman (Cushman colln. 24380), which has been designated as a junior synonym of $H$. pulchra by Montanaro-Gallitelli, is well preserved and exactly resembles the Pierre specimens. A hypotype of $H$. pulchra (Cushman colln. 24417) designated by MontanaroGallitelli has the overlap of chambers developed to a greater degree than is exhihited by the Pierre specimens.

Dimensions of average-sized specimens: length, about $0.3 \mathrm{~mm}$; breadth, 0.15 to $0.2 \mathrm{~mm}$; thickness, about $0.1 \mathrm{~mm}$.

Occurrence.-Prior to Montanaro-Gallitelli's (1957) study of the genera Guembelina and Heterohe?ix, most references to $H$. pulchra from the American Cretaceous were made as $G$. pseudotessera. Cushman (1946, p. 107) reported this species from beds of Austin and Taylor ages in the Gulf Coast deposits. It has been reported from the Niobrara Formation of South Dakota, Nebraska, and Kansas by Loetterle (1937, p. 34), of South Dakota by Bolin (1952, p. 40), of Wyoming by Shaw (1953, pl. 1, fig. 26), and of North Dakota by Grunseth $(1955$, p. 124). Other reports are from the Greenhorn Limestone of South Dakota (Fox, 1954, p. 101 (chart)), the Upper Cretaceous of Minnesota (Bolin, 1956, p. 290), the Upper Cretaceous of Maryland (Cushman, 1948a, p. 258), and the Red Bank, Navesink and Olsson's New Egypt Formations of New Jersey (Olsson, 1960, p. 27). This species has also been reported from the Cretaceous of Indonesia, the Netherlands, France, Egypt, Angola, Sweden, Denmark, Italy, and Puerto Rico.

In the upper part of the Pierre Shale, H. pulchra is usually found in samples that contain large numbers of H. globulosa but is never very abundant itself. It occurs in only one sample in which H. globulosa was not found. Stratigraphically, this species occurs from 74 feet above the upper key bentonite to 103 feet below the lower key bentonite.

Material.-Between 100 and 200 specimens were found.

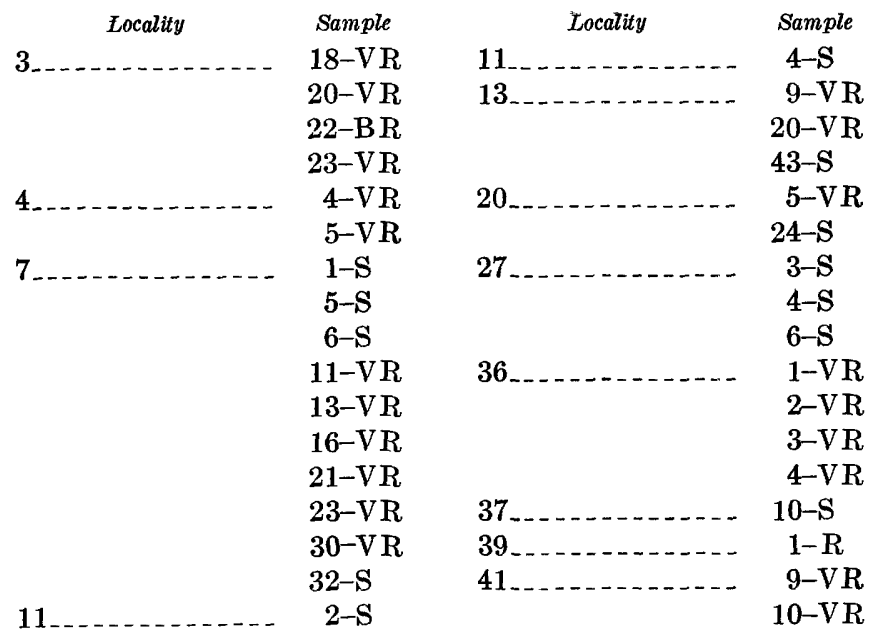

Genus BOIIVINOPSIS Yakovlev, 1891

Bolivinopsis rosula (Ehrenberg)

Plate 8, figure 6

Spiroplecta rosula Ehrenberg, 1854, Mikrogeologie, pl. 32, pt. 2, fig. 26.

Spiroplectoides rosula (Ehrenberg). Cushman, 1927, Cushman Lab. Foram. Research Contr., v. 3 , pt. 1, p. 62, pl. 13, figs. 9 a, b; v. 3, pt. 2, p. 114, pl. 23, figs. 6, 7 .

Bolivinopsis rosula (Ehrenberg). Macfayden, 1933, Royal Micros. Soc. Jour., 3d ser., v. 53, pt. 2, p. 141.

Test elongate, compressed, slender, the early part closely coiled, planispiral, sides approximately parallel in later biserial part, except where sporadic constrictions in the test occur, final part tends toward uniseriality; periphery acute, not keeled, slightly to moderately indented at the base of each chamber; chambers numerous in the biserial part, generally about as broad as high but with wide variation in this respect, oblique to the axis of elongation through a wide range of angles, planispiral part composed of four to five chambers arranged about a large central proloculus; sutures distinct, slightly to moderately limbate, slightly curved, depressed only at the periphery, nearly perpendicular to the axis of the test in the early biserial part, but angle progressively decreases with growth, median suture in early biserial part slightly sinuous and strongly limbate, in later biserial part, as it tends toward uniseriality, a slightly if at all limbate, conspicuously zigzag line, all degrees of limbation and sinuosity exist between these extremes; wall calcareous, smooth, polishec', finely perforate; aperture not preserved in any spacimens observed.

Dimensions of average-sized specimens: length, incomplete on all specimens; breadth of biserial part, 0.05 to $0.1 \mathrm{~mm}$; thickness of biserial part, abo'nt $0.05 \mathrm{~mm}$; 
breadth of coiled part, 0.1 to $0.15 \mathrm{~mm}$; thickness of coiled part, 0.05 to $0.1 \mathrm{~mm}$.

Occurrence.-Bolivinopsis rosula has been reported from beds of Austin, Taylor, and Navarro ages in the Gulf Coast deposits (Cushman, 1946, p. 101; Cushman, 1949 , p. 7), from the Niobrara Formation in Wyoming (Shaw, 1953, p. 48), from the Red Bank and Navesink Formations of New Jersey (Olsson, 1960, p. 27), and from the Upper Cretaceous of Maryland (Cushman, 1948a, p. 257). It has also been reported from the Cretaceous of the U.S.S.R.

In the upper part of the Pierre Shale, B. rosula occurs from 12 feet above the lower key bentonite to 103 feet below this bentonite.

Material.-More than 500 specimens were found.

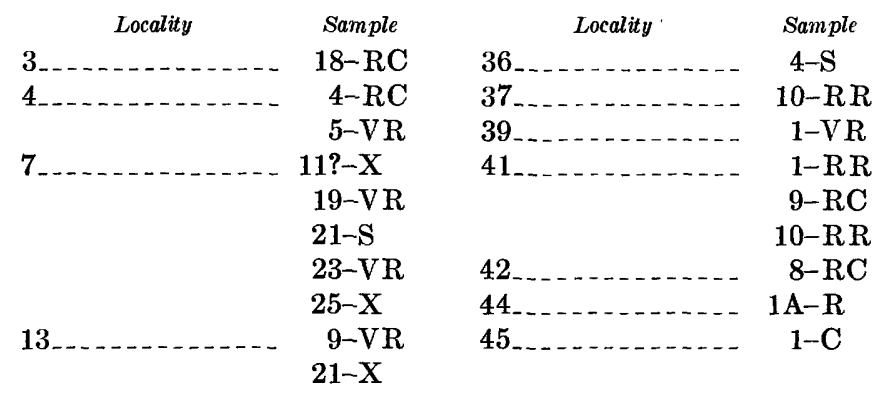

Genus RECTOGUEMBELINa Cushman, 1932

Rectoguembelina minuta Cushman

Plate 8 , figure 7

Rectogümbelina minuta Cushman, 1938, Cushman Lab. Foram. Research Contr., v. 14, pt. 2, p. 45, pl. 7, fig. 18.

Remarks.-Only two specimens referable to this species were found, but both are well preserved and very closely similar to the holotype of Rectoguembelina minuta. They differ only in being from one-half to twothirds the size of the holotype. The type description for $R$. minuta very adequately describes the Pierre specimens. Dimensions of the plesiotype: length, $0.21 \mathrm{~mm}$; breadth, $0.09 \mathrm{~mm}$.

Occurrence.-Rectoguembelina minuta, to the best of my knowledge, has only been reported once, from the lower part of the Taylor Marl in Texas (Cushman, $1938 \mathrm{a}$, p. 45 ). One of the Pierre specimens came from 103 feet below the lower key bentonite; the other specimen, from within 150 feet below the lower key bentonite.

Material.-Two specimens.

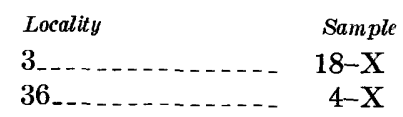

Genus BOLIVINOIDES Cushman, 1927

Bolivinoides decoratus (Jones) australis Edgell

Plate 8, figures 8a, b

Bolivinoides decorata (Jones) australis Edgell, 1954, Cushman Found Foram. Research Contr., v. 5, pt. 2, p. 71-72, pl. 13, figs. $5,6$.

Remarks.-The Pierre specimens are placed in Bolivinoides decoratus australis on the basis of the discontinuous ribs, rounded lateral margins, and presence of pustules nearly to the initial end of the test. The earliert, part of the test may be smooth or partially pustulose. The specimens differ from the subspecies gigantea in not having pustules that coalesce into continuous costae, and they differ from the subspecies decoratus in that more of the initial part of the test is ornamented.

Hofker (1958) suggested the use of the number of pustules on the last sutures of the subspecies of $B$. decoratus, that is, decoratus, australis and gigantea, as an index to the age of the deposits from which they came and used the number of pustules to subdivide the Belgian time-stratigraphic sequence from early Carnpanian to latest Maestrichtian into six parts. Six or seven specimens from a single Pierre sample have from four to seven pustules on the last sutures. This variation seems to be partly associated with test size, although there are differences in pustule number between specimens of approximately the same size. Thus no fine time-stratigraphic significance can be applied to the Pierre specimens on the basis of pustule number.

Hiltermann (1963, p. 204, table 1) indicated that $B$. decoratus australis is evolutionarily indetermediate between $B$. decoratus giganteus and B. decoratus decoratus. The time-stratigraphic ranges given by Hiltermann (1963, table 2) for the latter two subspecies indicate that $B$. decoratus australis is of probable late Campanian or early Maestrichtian age.

Dimensions of average-sized specimens : length, 0.45 to $0.5 \mathrm{~mm}$; breadth, 0.35 to $0.4 \mathrm{~mm}$; thickness, 0.15 to 0.2 $\mathrm{mm}$.

Occurrence.-Botivinoides decoratus australis was originally described from rocks of late Campanian age in northwestern Australia (Edgell, 1954, p. 71) and bas since been reported from the late Campanian to Maestrichtian of Belgium and Germany and from the Upper Cretaceous of Poland. This subspecies has never be?n reported from the Upper Cretaceous of North America, but the species $B$. decoratus has been frequently recorded, and specimens of the subspecies australis are probably included under this more general designation. In the upper part of the Pierre Shale, $B$. decoratus an'stralis occurs from just below to 6 feet below the lower key bentonite. 
Material.-15 specimens were found.

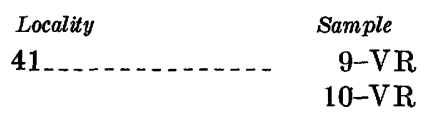

Genus TAPPaNINA Montanaro-Gallitelli, 1956

Tappanina costifera (Cushman)

Plate 8, figures 9a, b

Bolivinita costifera Cushman, 1937, Cushman Lab. Foram. Research Contr., v. 13, pt. 4, p. 105, pl. 15, fig. 15.

Tappanina costifera (Cushman). Montanaro-Gallitelli, 1956, Cushman Found. Foram. Research Contr., v. 7, pt. 2, p. 37, pl. 7, figs. 5-7.

Remarks.-A single specimen of this distinctively ornamented species was found. It is distinguished from the closely related species Tappanina selmensis (Cushman) by the more pronounced development of the sutural ridges. Dimensions of the specimen: length, 0.24 $\mathrm{mm}$; breadth, $0.11 \mathrm{~mm}$; thickness, $0.07 \mathrm{~mm}$.

Occurrence.-Tappanina costifera has been reported from the Arkadelphia Marl of Navarro age in Arkansas (Cushman, 1949, p. 8) and from the Upper Cretaceous of Maryland (Cushman, 1948a, p. 259, 267).

In the upper part of the Pierre Shale, T. costifera occurs 45 feet below the lower key bentonite.

Material.-One specimen was found.

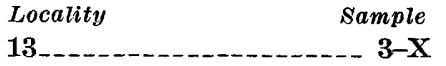

Family BULIMINIDAE Jones, 1876

Genus EOUVIGERINA Cushman, 1926

Eouvigerina aspera (Marsson) inflata Marie?

Plate 8, figures 11a-d

Test elongate, slightly compressed, slightly twisted and tapered, greatest width at the last two chambers, early part obscure; chambers distinct in later part, with smoothly arched upper surface the front and back margins of which attach to the earlier chambers and the lateral margins of which vary from sharply rounded to acute to slightly keeled and form the upper edges of flat inward-plunging flanges, these flanges form the lower lateral parts of the chambers; sutures moderately depressed in edge view, deeply indented in lateral view at the bases of the inward-plunging flanges; wall ornamentation ranges from nearly absent to a heavy covering of sharp short spines, those specimens most heavily covered with spines generally have the more rounded lateral chamber margins; aperture a rounded to ovate opening at the end of a short neck, with a distinct phialine lip. Dimensions of average-sized specimens: length, 0.2 to $0.25 \mathrm{~mm}$; breadth, about $0.1 \mathrm{~mm}$; thickness, about $0.1 \mathrm{~mm}$.

Remarks.-The few Pierre specimens exhibit a great deal of variation in amount of ornamentation, in angle of lateral chamber peripheries, and in amount of inflation of chambers. A result of these variations is that the specimens, which are basically the same in general morphology, are different in detail. The figures and description for Eouvigerina aspera inflata Marie (Marie, 1941 , p. 195 , pl. 29 , figs. 288,289 ) come closest to encompassing the average or typical morphology exhibited by the Pierre specimens. No type specimens were available for comparison, and Marie did not give a detailed explanation of the variation in the subspecies, so it has not been possible to determine whether the morphologic variation exhibited by the Pierre specimens is typical. Because of this uncertainty, positive assignment of the Pierre specimens to this subspecies has not been made.

Occurrence.-This subspecies has only been reported from the craie à Belemnitella mucronata of Late Cretaceous age in the Paris Basin.

Specimens were found from 6 feet above the lower key bentonite to 139 feet below this level in the upper part of the Pierre Shale.

Material.-Fewer than 40 specimens were found.

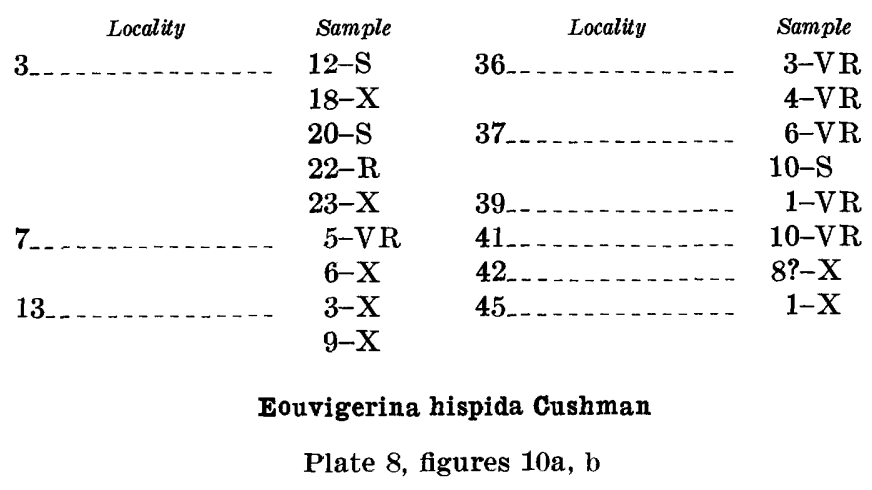

Eouvigerina hispida Cushman, 1931, Tennessee Div. Geology Bull. 41, p. 45, pl. 7, figs. 12, 13.

Remarks.-The holotype of this species is lost, but comparison with the paratypes reveals good agreement in most respects. One difference is the shorter biserial stage and correspondingly longer semiuniserial stage in the Pierre specimens. This type of chamber arrangement is similar to that in Eouvigerina geneae Morrow. Dimensions of a verage-sized specimens : length, 0.15 to $0.2 \mathrm{~mm}$; breadth, about $0.1 \mathrm{~mm}$; thickness, 0.05 to $0.1 \mathrm{~mm}$.

Occurrence.-Eouvigerina hispida has been reported from beds of Navarro, Taylor, and possibly Austin ages in the Gulf Coastal Plain deposits (Cushman, 1946, p. 116). Other reports are from the Mt. Laurel Formation of New Jersey (Jennings, 1936, p. 29), the Upper 
Cretaceous of Maryland (Cushman, 1948a, p. 260), and the Niobrara Formation of Wyoming (Shaw, 1953, p. 48).

In the upper part of the Pierre Shale this species occurs in samples from 20 to 139 feet below the lower key bentonite.

Material.-Fewer than 15 specimens were found.

$\begin{array}{crcc}\text { Locality } & \text { Sample } & \text { Locality } & \text { Sample } \\ & 12-\mathrm{S} & 36 \ldots \ldots \ldots & 5-\mathrm{X} \\ & 18-\mathrm{X} & 37 \ldots \ldots \ldots & 6-\mathrm{S} \\ 22-\mathrm{X} & & & 1-\mathrm{X}\end{array}$

Genus BULIMINA d'Orbigny, 1826

Bulimina reussi Morrow navarroensis Cushman and Parker

Plate 9, figures 1a-c

Bulimina reussi Morrow var. navarroensis Cushman and Parker, 1935, Cushman Lab. Foram. Research Contr., v. 11, pt. 4, p. 100, pl. 15, fig. 11.

Buliminella carseyae Plummer var. plana Cushman and Parker, 1936, Cushman Lab Foram. Research Contr., v. 12, pt. 1, p. 8, pl. 2, figs. 7a-c.

Test about $11 / 2$ times as long as broad, four whorls of chambers in large specimens, with about $31 / 2$ chambers per $360^{\circ}$ revolution about the axis of elongation, final whorl forms one-half to two-thirds the height of the test, longer specimens have chambers slightly in. flated, those specimens less than $11 / 2$ times as long as broad have more inflated chambers; sutures (including spiral suture) distinct, depressed'; wall smooth, finely perforate; aperture an elongate opening set in a depression in the nearly vertical apertural face, occasionally with a small basal interiomarginal slitlike extension at the junction with the previous chamber, generally only slightly inclined from the vertical. Dimensions of average-sized specimens: length, about $0.2 \mathrm{~mm}$; breadth, 0.1 to $0.15 \mathrm{~mm}$.

Remarks.-The Pierre specimens are very closely similar to the paratypes and holotype of Bulimina reussi var. navarroensis (herein designated as subspecies navarroensis). Comparison of the type specimens of $B$. reussi navarroensis with the holotype and paratypes of Buliminella carseyae Plummer var. plana Cushman and Parker revealed no consistent or significant differences. The holotypes are especially similar. There is nothing to recommend the continued separation of $B$. reussi navarroensis from $B$. carseyae plana, and consequently the latter name is herein considered to be a junior synonym of $B$. reussi navarroensis. The type specimens of Bulimina reussi were not available for study, and the type description and figure for this species are rather vague, so the nature of the parent species is not clear.
About two-thirds of the specimens from the upper part of the Pierre Shale are dextrally coiled.

Occurrence.-Bulimina reussi navarroensis and Buliminella carseyae plana, which is here regarded as its junior synonym, have been reported from beds of Navarro age in the Gulf Coast Cretaceous deposits (Cushman, 1946, p. 120, 121). Other occurrences are from the Upper Cretaceous of Israel, Colombia, and Italy and from the late Senonian of France.

In the upper part of the Pierre Shale, this subspecies is found from 17 feet below the base of the Fox Hills Sandstone to 156 feet below the lower key bentonite.

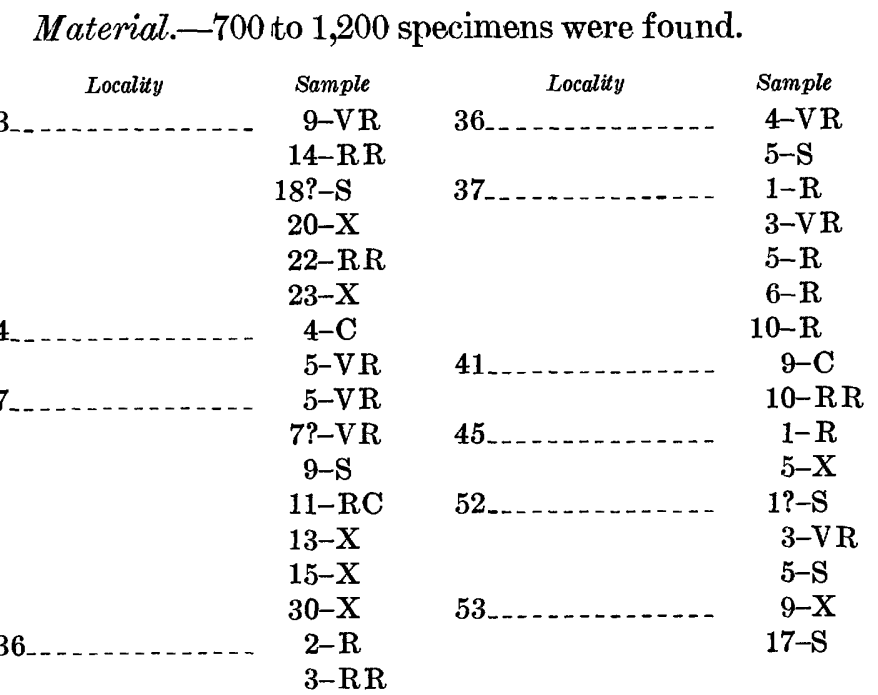

Bulimina kickapooensis Cole

Plate 8 , figures $14 a, b ; 15 a, b$

Bulimina kickapooensis Cole, 1938, Florida Dept. Conserv. Geol. Dept. Bull. 16, p. 45, pl. 3, fig. 5 .

Bulimina kickapooensis Cole var. pingua Cushman and Parker, 1940, Cushman Lab. Foram. Research Contr., v. 16, pt. 2, p. 44, pl. 8, figs. 13, 14 .

Test in larger specimens composed of about five whorls; megalospheric specimens range from 1.7 to 2.5 times as long as broad, microspheric specimens range from 1.9 to 2.5; megalospheric form tapers slightly to a blunt initial end, microspheric form tapers markedly to a pointed initial end; chambers numerous, distinct, slightly inflated; sutures distinct, slightly depressed, spiral suture irregular and indistinot; wall smooth, perforate, perforations present only in that part of each chamber that remains exposed after the next higher whorl is added; aperture at apex of test, ovate, actual opening into the interior commashaped because of the presence of a troughlike toothplate along one side of the aperture; this plate connects with a similar plate in the aperture of the previous chamber and thus a continuous 
connection between apertures is formed. Length-breadth measurements of several specimens in millimeters, are:

\begin{tabular}{ccccc}
\hline \multicolumn{2}{c}{ Megalospheric } & & \multicolumn{2}{c}{ Microspheric } \\
\cline { 1 - 1 } Length & Breadth & & Length & Breadth \\
\hline 0.55 & 0.22 & & 0.47 & 0.25 \\
.44 & .23 & & .42 & .22 \\
.36 & .21 & & .39 & .16 \\
\hline
\end{tabular}

Remarks.-In most samples examined, megalospheric specimens were more abundant than microspheric. Two gerontic individuals with paired final chambers were observed.

The toothplate arises either from the left or right side of the aperture, but in each of the four or five Pierre specimens sectioned, it arises from the half of the final chamber that more fully overlaps the penultimate chamber. The free side of the toothplate is flush with the surface of the chamber or is very slightly raised above it, and in one well-preserved specimen, this free edge is faintly serrated. Within the final chamber the toothplate, which is as long as the aperture immediately below the apertural opening, narrows like a funnel as it parallels the apertural surface of the chamber in its course downward toward the penultimate aperture. The toothplate is gently curved because of this narrowing and is slightly twisted as its axis changes from parallel with the final aperture to parallel with the penultimate aperture. The toothplate widens again at its base where it attaches to the forward or upper half of the toothplate extending from the penultimate aperture. The toothplate of the penultimate aperture may be on the same side or the opposite side of the aperture from the toothplate of the final aperture.

This species is one of the most abundant and persistent in the upper part of the Pierre Shale. The numerous specimens observed show a moderate amount of variation in length and in inflation of chambers. Many of the shorter specimens compare well with the holotype of Bulimina kickapooensis Cole var. pingua Cushman and Parker, but other specimens are exactly similar to the holotype of B. kickapooensis Cole. Because of the occurrence of both of these morphologic types in the same samples and the presence of specimens of intermediate morphology, var. pingua is not recognized as a valid subspecies.

$B$. aspera Cushman and Parker is very similar morphologically to $B$. kickapooensis, but differs in $" * * *$ the smaller size, greater inflation of the chambers, the roughened early portion of the test and usual presence of one or two short spines" (Cushman, 1946, p. 121). These differences are not present in many specimens of B. aspera in the U.S. National Museum collections, and further study may show that B. aspera and R. kickapooensis are synonymous.

Occurrence.-In the United States Butimina kickapooensis has been reported from beds of Austin, Taylor, and Navarro ages in the Gulf Coast deposits (Cushman, 1946 , p. 123) and from the Hilliard Shale of Campanian-Santonian age in Wyoming (Gauger, in Jones, 1953, p. 79). Elsewhere, it has been reported from the Upper Cretaceous of Colombia, Venezuela, and Curacao, and from the late Campanian of Israel, the Maestrichtian of Egypt, and the Santonian to Maestrichtian of Puerto Rico.

In the upper part of the Pierre Shale, this species occurs from 84 feet above the upper key bentonite to the base of the sampled section, 197 feet below the lower key bentonite.

Material.-Several thousand specimens were found.

\begin{tabular}{|c|c|c|c|}
\hline Locality & Sample & Locality & Sample \\
\hline \multirow{4}{*}{$1 \ldots \ldots \ldots$} & 1-RC & $11 \ldots$ & 41-VR \\
\hline & $3-S$ & & $43-V R$ \\
\hline & $5-\mathrm{RR}$ & 20 & 5-RR \\
\hline & $7 ?-\mathrm{RR}$ & & $11-\mathrm{VC}$ \\
\hline \multirow{10}{*}{3} & 1-C & & $17-X$ \\
\hline & $3-\mathrm{RR}$ & $27 \ldots$ & $1-R R$ \\
\hline & $5-V R$ & & $3-C$ \\
\hline & 7-RR & & $4-C$ \\
\hline & $9-\mathrm{RR}$ & & $6-\mathrm{VC}$ \\
\hline & $11-R R$ & & $7-\mathrm{RC}$ \\
\hline & $12-\mathrm{C}$ & & $9-\mathrm{C}$ \\
\hline & $20-\mathrm{RC}$ & $27 \mathrm{~A}$ & 2-RR \\
\hline & 22-RR & & $3-R$ \\
\hline & $23-\mathrm{RC}$ & & $7-R$ \\
\hline \multirow[t]{3}{*}{5} & 4-R & & $9-S$ \\
\hline & $5-X$ & 36 & 1-RC \\
\hline & 8-RR & & $2-\mathrm{VR}$ \\
\hline \multirow[t]{10}{*}{7} & $15-\mathrm{C}$ & & 3-RR \\
\hline & 16-RC & & $4 ?-\mathrm{X}$ \\
\hline & 17-RC & & 5-VR \\
\hline & 19-RC & $37 \ldots$ & $1-V R$ \\
\hline & 21-RC & & 3-RR \\
\hline & $23-\mathrm{C}$ & & $5-V R$ \\
\hline & 25-RR & & 6-R \\
\hline & $27-\mathrm{S}$ & & $10-\mathrm{RR}$ \\
\hline & 29-R R & & $12-\mathrm{R}$ \\
\hline & $32-\mathrm{S}$ & 39 & 1-RR \\
\hline \multirow[t]{2}{*}{11} & $2-\mathrm{VR}$ & $41 \ldots$ & $1-\mathrm{RR}$ \\
\hline & 3-R R & & $11-V R$ \\
\hline \multirow[t]{13}{*}{$13 \ldots$} & $1-\mathrm{RC}$ & $42 \ldots$ & 7-RC \\
\hline & $3-\mathrm{RC}$ & & $8-\mathrm{C}$ \\
\hline & 5-RR & $44 \ldots \ldots$ & $1 \mathrm{~A}-\mathrm{RC}$ \\
\hline & $9-\mathrm{C}$ & & 5-RR \\
\hline & $10-C$ & & 8-VR \\
\hline & $12-\mathrm{R} R$ & & $15-\mathrm{VR}$ \\
\hline & $14-\mathrm{RC}$ & & $17-\mathrm{RC}$ \\
\hline & $16-R$ & & $19-\mathrm{RC}$ \\
\hline & $20-\mathrm{RC}$ & 45 & $1-\mathrm{C}$ \\
\hline & $21-\mathrm{S}$ & & $3-\mathrm{R}$ \\
\hline & 23-RR & & $7-\mathrm{C}$ \\
\hline & $37-\mathrm{C}$ & $49 \ldots$ & $5-X$ \\
\hline & $40-C$ & & $7-R$ \\
\hline
\end{tabular}




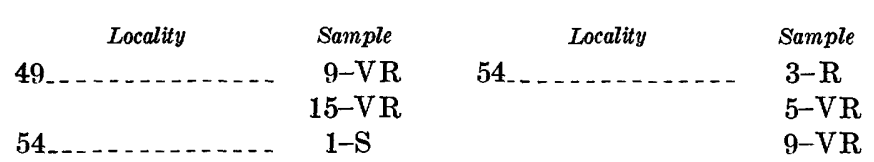

Bulimina arkadelphiana Cushman and Parker

Plate 8 , figures $12 ; 13 a, b$

Bulimina arkadelphiana Cushman and Parker, 1935. Cushman Lab. Foram. Research Contr., v. 11, pt. 4, p. 96, pl. 15, figs. 1-2.

Test elongate, rather rapidly tapering, large specimens consist of about four whorls, final whorl comprising half the test; chambers slightly inflated, overlapping; sutures distinct, slightly depressed, not limbate, spiral suture distinct, rather deeply incised, overhung by the upper chambers; wall, except for the last three chambers, covered with sharp elongate spines, especially at the margins of the chambers, chambers of the last-formed whorl with spines at the peripheral margins and with only occasional spines above, finely perforate; aperture large and oval, in some specimens with a pronounced trough-shaped toothplate which arises at the side of the aperture and plunges into the chambers, most specimens with a raised flange at one side of the aperture and without development of the toothplate, some specimens lacking both flange and toothplate. Dimensions of average-sized specimens: length, about 0.3 $\mathrm{mm}$; breadth, about $0.2 \mathrm{~mm}$.

Remarks. - The troughlike surficial expression of the toothplate in this species is similar to that found in Bulimina kickapooensis, but its internal morphology was not examined.

Although $B$. arkadelphiana is a distinctive species, because of its ornamentation, it is not easily distinguished from B. arkadelphiana var. midwayensis Cushman and Parker. These authors distinguished their variety from $B$. arkadelphiana on the basis of higher and more inflated chambers in the final whorl and the presence of a basal spine. The Pierre specimens have higher chambers in the final whorl than the holotype and paratypes of $B$. arkadelphiana, but these chambers are not as inflated as they are in the type specimens of $B$. ark $a-$ delphiana var. midwayensis. Several of the Pierre specimens and several of the paratypes of $B$. arkadelphiana have basal spines as well developed as those in the holotype of var. midwayensis. Thus, the criterion of chamber inflation seems to be the only means of distinguishing these two forms. Because the inflation in the Pierre specimens is more than in the types of $B$. arkadelphiana and less than in the types of var. midwayensis, it does not appear that this character can be relied upon to differentiate the two forms. Consequently, I have placed the Pierre specimens in the species arkadelphiana witl out subspecific differentiation.

Occurrence.-Bulimina arkadelphiana var. midwa?'ensis has only been reported from deposits of Paleocera age. Cushman $(1964$, p. 124) reported B. arkadelphiana from the Arkadelphia Marl of Navarro age in Arkansas. This species has also been reported from beds $\mathrm{cf}$ Maestrichtian age in Denmark and Egypt.

In the upper part of the Pierre Shale this species occurs from immediately above the lower key bentonite to 40 feet below this level.

Material.-Fewer than 100 specimens were found.

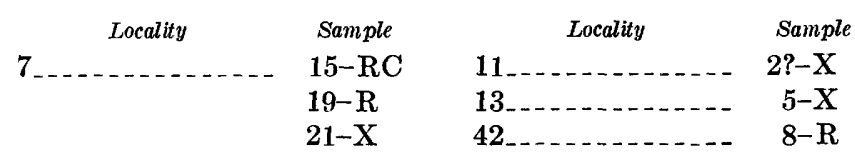

Bulimina prolixa Cushman and Parker

Plate, 9, figures 2a-c

Bulimina prolixa Cushman and Parker, 1935, Cushman Lab. Foram. Research Contr., v. 11, pt. 4, p. 98, pl. 15, figs. 5a, b.

Remarks.-The specimens correspond very well to the holotype and paratypes of Bulimina prolixa and differ only in averaging twice as long as broad instead cf $21 / 2$ times as long as broad. Also, perforations seem to be lacking in a narrow corona about the aperture. Dimensions of average-sized specimens: length, 0.2 to 0.25 $\mathrm{mm}$; breadth, 0.1 to $0.15 \mathrm{~mm}$.

Occurrence.-In the United States, Bulimina prolixa occurs in beds of Taylor and Navarro ages in the Gulf Coast deposits (Cushman, 1946, p. 122), in the Cod' Shale of Wyoming (Fox, 1954, p. 105), and in the Uppe" Cretaceous of Maryland (Cushman, 1948a, p. 261) and California (Cushman and Goudkoff, 1944, p. 5ह; Schenck, 1943, p. 62). Elsewhere, this species has been reported from the late Campanian of Israel, the Maestrichtian of Egypt, and the Upper Cretaceous of Italy and France.

This species was found in the upper part of the Pierre Shale from 31 feet above the upper key bentonite to 82 feet below the lower key bentonite, with one possible occurrence 183 feet above the upper key bentonite.

Material.-Fewer than 75 specimens were found.

\begin{tabular}{|c|c|c|c|}
\hline Locality & Sample & Locality & Sample \\
\hline 3 & $\begin{array}{l}20-X \\
22-X\end{array}$ & $41 \ldots \ldots$ & $\begin{array}{l}1-S \\
3-X\end{array}$ \\
\hline 5 & 5-RR & & $5-X$ \\
\hline 7 & $11-X$ & & $9-X$ \\
\hline $20 \ldots$ & $17-R$ & & $10-S$ \\
\hline $37 \ldots$ & $\begin{array}{r}5-S \\
10-S\end{array}$ & $52 \ldots$ & $5 ?-\mathrm{X}$ \\
\hline
\end{tabular}


Genus NEOBULIMINA Cushman and Wickenden, 1928

Neobulimina canadensis Cushman and Wickenden var. alpha, n. var.

Plate 9, figures 5a-c

Neobulimina canadensis Cushman and Wickenden, 1928, Cushman Lab. Foram. Research Contr., v. 4, pt. 1, p. 13, pl. 1, figs. 1, 2.

Test elongate, initially trochoid, later biserial, greatest breadth at the final pair of chambers; early chambers in an approximately triserial arrangement; each successive triplet of chambers is generally slightly offset from the triplet beneath, the offsetting giving most specimens a slightly to moderately twisted appearance; larger specimens develop a biserial stage which composes about half the length of the test; chambers distinct, subglobular, and inflated throughout; sutures distinct, depressed; wall roughened except for the upper parts of the final chambers; some specimens have numerous small rugosities on the early chambers, perforations of moderate size: aperture in the triserial part a small comma-shaped to oval opening at the base of the chamber near the midline of the test, in the biserial portion more elongate, set in a depression in the apertural face, the base formed by the top of the underlying chamber, lies parallel to the plane of compression, possibly with a toothplate. Dimensions of average-sized specimens having biserial chambers: length, about $0.15 \mathrm{~mm}$; length of triserial part, 0.65 to $0.1 \mathrm{~mm}$; breadth of triserial part, about $0.05 \mathrm{~mm}$; breadth of biserial part, about $0.1 \mathrm{~mm}$; thickness of biserial part, 0.05 to $0.1 \mathrm{~mm}$.

Remarks.-The specimens included under this designation correspond to what I consider to be the typical form of Neobulimina canadensis. They differ from the type description of $N$. canadensis in having a roughened to slightly rugose wall, perforations of only moderate size, and smaller average specimen size. Agreement with the type figure and description, and with comparative material, is good in all other respects.

The following plesiotypes and unfigured specimens in the U.S. National Museum collections that belong in this variety are listed below with their stratigraphic designations, general localities, and slide numbers (slide 106505 is in the U.S. National Museum accession series; all others are Cushman collection numbers) :

\begin{tabular}{|c|c|c|}
\hline Stratigraphic designation & General locality & Slide \\
\hline \multicolumn{3}{|l|}{ Plesiotypes: } \\
\hline Taylor Marl ${ }^{1}$ & Near McKinney, Tex ..... & 22578 \\
\hline $\begin{array}{l}\text { Austin Chalk, lower part } \\
\text { of Mooreville Chalk } \\
\text { of Selma Group. }\end{array}$ & $\begin{array}{l}\text { Near Mooreville, } \\
\text { Itawamba County, } \\
\text { Miss. }\end{array}$ & 42492 \\
\hline $\begin{array}{l}\text { Schrader Bluff Forma- } \\
\text { tion. }{ }^{3}\end{array}$ & Near Umiat, Alaska $\ldots$ & 106505 \\
\hline
\end{tabular}

\begin{tabular}{|c|c|c|}
\hline Stratigraphic designation & General locality & Slide \\
\hline \multicolumn{3}{|l|}{ Unfigured specimens: } \\
\hline Selma Group & $\begin{array}{l}\text { Near Mooreville, Lee } \\
\text { County, Tex. }\end{array}$ & 35543 \\
\hline $\begin{array}{l}\text { Upper Wolfe City Sand } \\
\text { Member of Taylor Marl. }\end{array}$ & Near Wolfe City, Tex & 35538 \\
\hline $\begin{array}{l}\text { Wolfe City Sand } \\
\text { Member of Taylor } \\
\text { Marl. }\end{array}$ & Near Hillsboro, Tex..... & 35539 \\
\hline Annona Chalk & $\begin{array}{l}\text { Near Clarksville, Red } \\
\text { River County, Tex. }\end{array}$ & 35540 \\
\hline Bonham Clay ........ & $\begin{array}{l}\text { Near Hinckley, Lamar } \\
\text { County, Tex. }\end{array}$ & 35607 \\
\hline Taylor $\ldots \ldots$ & Palmer, Tex & 35614 \\
\hline Selma Group $\ldots$ & $\begin{array}{l}\text { Near Guys, McNairy } \\
\text { County, Tenn. }\end{array}$ & 15958 \\
\hline Bearpaw Shale ........ & $\begin{array}{l}\text { Lethbridge, Alberta, } \\
\text { Canada. }\end{array}$ & 35618 \\
\hline Taylor $\ldots \ldots$ & Near Ennis, Tex & 35551 \\
\hline upper Taylor & $\begin{array}{l}\text { Near Forney, Kaufman } \\
\text { County, Tex. }\end{array}$ & 35552 \\
\hline upper Taylor. .......... & $\begin{array}{l}\text { Near Castroville, Bexar } \\
\text { County, Tex. }\end{array}$ & 35553 \\
\hline lower Taylor Marl ...... & $\begin{array}{c}\text { Near Bagwell Sta., Red } \\
\text { River County, Tex. }\end{array}$ & 35596 \\
\hline lower Taylor & $\begin{array}{l}\text { Near Lorena, McLennon } \\
\text { County, Tex. }\end{array}$ & 35598 \\
\hline lower Taylor $\ldots \ldots$ & Near Hillsboro, Tex & 35572 \\
\hline lower Taylor. & $\begin{array}{l}\text { McKinney, Collins } \\
\text { County, Tex. }\end{array}$ & 35570 \\
\hline Taylor $\ldots \ldots \ldots$ & Near Wolfe City, Tex..... & 35569 \\
\hline $\begin{array}{l}\text { Austin Chalk, lower } \\
\text { part of Mooreville } \\
\text { Chalk of Selma } \\
\text { Group. }\end{array}$ & $\begin{array}{l}\text { Near Mooreville, } \\
\text { Itawamba County, } \\
\text { Miss. }\end{array}$ & 42493 \\
\hline
\end{tabular}

i Cushman (1936, pl. 2, fig. 9).

${ }^{2}$ Cushman (1944b, pl. 14, figs. 12, 13).

${ }_{3}$ Tappan (1962, pl. 48, figs. 21, 27 (not fig. 25)).

Occurrence.-The occurrences cited below include all the references to Neobulimina canadensis of which I am aware. No attempt is made here to separate these references according to the varieties recognized by me. The only such separations so far made are referred to under "Remarks."

$N$. canadensis was originally recorded from the Lethbridge Shale of Alberta, Canada. Cushman (1946, p. 125) recorded it from the Eagle Ford Shale and from beds of Austin, Taylor, and Navarro ages in the Gulf Coast deposits. Other occurrences in the United States are from the Niobrara Formation of South Dakota (Bolin, 1952, p. 44) and Wyoming (Shaw, 1953, p. 48), the Sage Breaks Member of the Carlile Shale and the Greenhorn Formation (Fox, 1954, p. 101, 106), the Tuluga Member of the Schrader Bluff Formation of northern Alaska (Tappan, 1951, p. 5) (now considered to be a member of the Seabee Formation, according to Tappan, 1962, p. 97), the Rogers Creek and Sentinel Hill Members of the Schrader Bluff Fcrmation of 
northern Alaska (Tappan, 1962, p. 185), and the Navesink Formation of New Jersey (Jennings, 1936, p. 31). $N$. canadensis has also been reported from the Upper Cretaceous of the Spanish Sahara and, with question, from the Upper Cretaceous of Peru and Egypt.

In the upper part of the Pierre Shale, $N$. canadensis var. alpha occurs 48 to 139 feet below the lower key bentonite.

Material.-Fewer than 40 specimens were found.

$\begin{array}{crcc}\text { Locality } & \text { Sample } & \text { Locality } & \text { Sample } \\ 3 \ldots & 12 ?-\mathrm{X} & 3 \ldots \ldots \ldots & 23-\mathrm{X} \\ 16-\mathrm{R} & 37 \ldots \ldots \ldots \ldots & 1-\mathrm{R} \\ 20-\mathrm{S} & 39 \ldots \ldots \ldots \ldots & 1-\mathrm{VR} \\ & 22 ?-\mathrm{S} & & \end{array}$

Neobulimina canadensis Cushman and Wickenden var. beta, n. var.

Plate 9, figures $4 a-C$

Test about three times as long as broad, nearly twice as broad as thick, tapers gradually from the acute but rounded base, earliest part trochoid, approximately triserial, length of trochoid part variable, most of the test biserial in larger specimens, biserial part very slightly if at all twisted, lateral peripheries broadly rounded perpendicular to, and moderately lobulate parallel to, the axis of elongation; chambers, numerous, distinct, inflated, slightly higher than broad in final few pairs in larger specimens, generally broader than high; sutures distinct, depressed, shightly to moderately oblique to the axis of elongation; wall smooth, appearing roughened in specimens not perfectly preserved, perforations of moderate size; aperture in the plane of the test, narrow, about twice as high as broad U-shaped, apparently with a toothplate, with the basal periphery formed by the top of the previous chamber, set rather deeply in the apertural face. Dimensions of average-sized specimens: length about $0.25 \mathrm{~mm}$; length of triserial part, about $0.05 \mathrm{~mm}$; breadth of triserial part, somewhat less than $0.05 \mathrm{~mm}$; breadth of biserial part, 0.05 to $0.1 \mathrm{~mm}$; thickness of biserial part, about $0.05 \mathrm{~mm}$.

Remarks.-This variety differs importantly from var. alpha in having a much reduced triserial part. In other respects, including size, these varieties are similar, except that no well-preserved specimens of var. beta had a roughened wall. These two varieties do not occur together in any sample from the upper part of the Pierre Shale and were first considered to be two separate species. In my examination of specimens of Neobulimina canadensis in the U.S. National Museum collections, I found several slides containing specimens of both varieties, which presumably also occurred together in the samples. A few of these specimens seem to be transi- tional between the two varieties. Both varieties ar? placed in $N$. canadensis because of the general morphologic similarity between them, except as noted, and because of the occurrence of both varieties in several samples from other areas. Possible intermediate specimens are found in these other samples. These varietie: are distinguished here to indicate the morphologic differences shown by them and to preserve the stratigraphic separation that they have in the upper part of the Pierre Shale. Future study of samples in which both varieties are abundantly represented should clarify their relationship.

The following plesiotypes and other specimens in the U.S. National Museum collections considered to belong in var. beta are listed below with their stratigraphic designations, general localities, and slide numbers (all slide numbers are Cushman collection numbers) :

\begin{tabular}{|c|c|c|}
\hline Stratigraphic designation & General locality & Slide \\
\hline \multicolumn{3}{|l|}{ Plesiotypes: } \\
\hline Taylor Marl ${ }^{1} \ldots$ & Near Ennis, Tex $\ldots$ & 22577 \\
\hline Selma Group ${ }^{2} \ldots \ldots$ & $\begin{array}{l}\text { Near Sardis, Henderson } \\
\text { County, Tenn. }\end{array}$ & $1522^{2}$ \\
\hline \multicolumn{3}{|l|}{ Unfigured specimens: } \\
\hline Boyne beds . . . . & $\begin{array}{l}\text { Near Babcock, Manitoba, } \\
\text { Canada. }\end{array}$ & $2122^{2}$ \\
\hline Taylor & Near Ennis, Tex $\ldots$ & 35551 \\
\hline upper Taylor...... & $\begin{array}{l}\text { Near Forney, Kaufman } \\
\text { County, Tex. }\end{array}$ & 35552 \\
\hline upper Taylor.......... & $\begin{array}{l}\text { Near Castroville, Bexar } \\
\text { County, Tex. }\end{array}$ & 35553 \\
\hline middle Taylor Marl_..... & Kaufman County, Tex & 35597 \\
\hline lower Taylor Marl _..... & $\begin{array}{c}\text { Near Bagwell Sta., Red } \\
\text { River County, Tex. }\end{array}$ & 3559 ? \\
\hline lower Taylor... & $\begin{array}{l}\text { Just below Wolfe City } \\
\text { Sand, Honey Grove, } \\
\text { Fannin County, Tex. }\end{array}$ & 35575 \\
\hline Selma Group............... & $\begin{array}{l}\text { Near Guys, McNairy } \\
\text { County, Tenn. }\end{array}$ & 15958 \\
\hline Selma Group & $\begin{array}{l}\text { Near Mooreville, Lee } \\
\text { County, Miss. }\end{array}$ & 35543 \\
\hline Selma Group .......... & Near Tupelo, Miss_......... & 35541 \\
\hline $\begin{array}{l}\text { Wolfe City Sand } \\
\text { Member of Taylor } \\
\text { Marl. }\end{array}$ & Near Wolfe City, Tex $\ldots$ & 35537 \\
\hline Selma Group.......... & $\begin{array}{l}\text { Near Sardis, Henderson } \\
\text { County, Tenn. }\end{array}$ & 15957 \\
\hline Taylor.... & $\begin{array}{l}\text { Near McKinney, Collins } \\
\text { County, Tex. }\end{array}$ & 35565 \\
\hline lowe & McKinney, Tex & 35571 \\
\hline lower Taylor $\ldots \ldots \ldots$ & $\begin{array}{l}\text { Near Paris, La mar County, } \\
\text { Tex. }\end{array}$ & 35574 \\
\hline Selma Group, near top_- & $\begin{array}{l}\text { Near Graham, Union } \\
\text { County, Miss. }\end{array}$ & 35546 \\
\hline aylor group. & & \\
\hline
\end{tabular}

1 Cushman and Parker (1936, pl, 2, figs. 10a, b).

2 Cushman (1931a, pl. 8, figs. 1a-c). 
Occurrence.-The published occurrences of Neobulimina canadensis are recorded under var. alpha. Var. beta occurs from just below the upper key bentonite to 57 feet above this level.

Material.-About 500 specimens were found.

\begin{tabular}{|c|c|c|c|}
\hline Locality & Sample & Locality & Sample \\
\hline 5 & 8-RR & $49 \ldots$ & $1-\mathrm{RC}$ \\
\hline 7 & $30-\mathrm{RC}$ & & $5-\mathrm{C}$ \\
\hline $27 A_{\ldots} \ldots$ & 3-VR & & $9-\mathrm{RC}$ \\
\hline & $5-S$ & & \\
\hline
\end{tabular}

Neobulimina navarroana (Cushman)

Plate 9, figures 3a-C

Virgulina navarroana Cushman, 1933, Cushman Lab. Foram. Research Contr., v. 9, pt. 3, p. 63, pl. 7, figs. 9, 10.

Test elongate, fusiform in smaller specimens, not compressed, sides parallel or gradually tapering toward the initial end in larger specimens, lateral peripheries broadly rounded perpendicular to and slightly lobulate parallel to the axis of elongation; chambers distinct, slightly inflated, overlapping, irregularly spirally arranged in early part, become biserial later; sutures distinct, slightly depressed; wall smooth, with perforations of moderate size; aperture roughly comma shaped, depressed in the apertural face, not very distinct, toothplate believed present but not positively recognized. Dimensions of average-sized specimens: length, 0.25 to 0.3 $\mathrm{mm}$; length of triserial part, 0.05 to $0.1 \mathrm{~mm}$; breadth of triserial part, 0.05 to $0.1 \mathrm{~mm}$; breadth of biserial part, about $0.1 \mathrm{~mm}$; thickness of biserial part, 0.05 to $0.1 \mathrm{~mm}$.

Remarks.-Loeblich and Tappan $(1957$, p. 227, 228) studied topotypes of Virgulina squammosa d'Orbigny, the type species of the genus Virgulina, and reported that their specimens showed a highly twisted biserial arrangement of chambers in the early part of the test rather than a triserial arrangement. $V$. navarroana Cushman definitely has an irregular triserial or bulimine arrangement of chambers in the early part and thus does not belong in the genus Tirgulina. This species is, in fact, quite readily accommodated in the genus Neobulimina Cushman and is here placed in that genus.

The Pierre specimens differ from the type specimens of $N$. navarroana in lacking a basal spine and in having a multiserial stage that persists higher than in the types.

Several slides in the U.S. National Museum collections labeled $N$. canadensis contain specimens that are very similar to the Pierre specimens placed in $N$. navarroana and to the type specimens of this species. A list of the stratigraphic designations, general localities, and slide numbers of these slides is given below. Some of these specimens appear to be transitional between $N$. canadensis var. alpha and $N$. navarroana. A study of both species, in greater detail than was attempted here, must be made before the nature of this relationship can be made clear. (All slide numbers are Cushman collection numbers.)

\begin{tabular}{|c|c|c|}
\hline Stratigraphic designations & General locality & Slide \\
\hline Selma Group... & $\begin{array}{l}\text { Near Selmer, McNair: } \\
\text { County, Tenn. }\end{array}$ & 15959 \\
\hline lower Taylor Marl & $\begin{array}{l}\text { Near Bagwell Sta., Red } \\
\text { River County, Tex. }\end{array}$ & 35596 \\
\hline Neylandville Marl_ & $\begin{array}{l}\text { Near Kaufman, Kaufman } \\
\text { County, Tex. }\end{array}$ & 35557 \\
\hline lower Taylor & $\begin{array}{l}\text { Near Pleasant Grove, } \\
\text { Dallas County, Tex. }\end{array}$ & 35601 \\
\hline Neylandville Marl & $\begin{array}{l}\text { Near Cooper, Delta } \\
\text { County, Tex. }\end{array}$ & 35527 \\
\hline upper Austin. & $\begin{array}{l}\text { Near Whitewright, Gray- } \\
\text { son County, Tex. }\end{array}$ & 35604 \\
\hline lower Taylor Marl . & $\begin{array}{l}\text { Near Buckner Orphars } \\
\text { Home, east of Dallas, } \\
\text { Tex. }\end{array}$ & $\begin{array}{r}35591, \\
35593\end{array}$ \\
\hline Austi & Near Dallas, Tex. $\ldots . .$. & 35587 \\
\hline Taylor $_{\ldots} \ldots \ldots$ & Near Hillsboro, Tex & 35562 \\
\hline uppermost Taylor......... & $\begin{array}{l}\text { Near Terrell, Kaufman } \\
\text { County, Tex. }\end{array}$ & 35534 \\
\hline Selm & Near Guntown, Miss $\ldots \ldots$ & 35542 \\
\hline lower Taylor & $\begin{array}{l}\text { Near Paris, Lamar County, } \\
\text { Tex. }\end{array}$ & 35574 \\
\hline middle Brownstown Marl _ - & $\begin{array}{l}\text { Near Paris, Lamar Ccinty, } \\
\text { Tex. }\end{array}$ & 35577 \\
\hline
\end{tabular}

Occurrence.-Neobulimina navarroana (=Virgulina navarroana) has been reported from beds of Navarro age in Texas (Cushman, 1946, p. 126) and Arkansas (Cushman, 1949, p. 8), from beds of Maestrichtian age and younger in New Jersey (Olsson, 1960, p. 33), and from the Upper Cretaceous of the Georges Bank canyons (Cushman, 1936, p. 419). Other reports are from the Upper Cretaceous of Trinidad and Egypt.

In the upper part of the Pierre Shale, this species occurs from immediately above the upper key bentonite to 71 feet above this level and is doubtfully identified from as high as 115 feet above this level.

Material.-1,000 to 1,500 specimens were found.

\begin{tabular}{|c|c|c|c|}
\hline Locality & Sample & Locality & Sample \\
\hline $5 \ldots \ldots \ldots$ & 8-R & $44 \ldots$ & $23-\mathrm{RC}$ \\
\hline \multirow[t]{2}{*}{7} & $30-\mathrm{RR}$ & 49 & 1-RC \\
\hline & $32-\mathrm{C}$ & & $3 ?-\mathrm{VR}$ \\
\hline $27 \ldots \ldots \ldots$ & $3-S$ & & $5-\mathrm{R}$ \\
\hline \multirow{6}{*}{$27 \mathrm{~A}_{\ldots} \ldots$} & $2-\mathrm{VR}$ & & $7 ?-\mathrm{S}$ \\
\hline & $5-\mathrm{S}$ & & 9-VC \\
\hline & $6-\mathrm{R}$ & & $11 ?-\mathrm{R}$ \\
\hline & 7-RR & & $13 ?-\mathrm{S}$ \\
\hline & $9 ?-\mathbf{S}$ & & $15 ?-\mathrm{VR}$ \\
\hline & $15 ?-\mathrm{S}$ & $53 \ldots \ldots$ & $5 ?-V R$ \\
\hline \multirow[t]{3}{*}{$44_{4} \ldots$} & $12-\mathrm{A}$ & 54 & $1-R$ \\
\hline & $19-\mathrm{A}$ & & 3-VR \\
\hline & $21-S$ & & $11 ?-\mathrm{VR}$ \\
\hline
\end{tabular}




\section{Genus BoIIVIrA d'Orbigny, 1839}

Bolivina decurrens (Ehrenberg)

Plate 9, figures 6a, b

Grammostomum? decurrens Ehrenberg, 1854, Mikrogeologie, pl. 30, fig. 17.

Bolivina decurrens (Ehrenberg). Marsson, 1878, Naturw. Ver. Neu-Vorpommern u. Rügen Mitt., Jahrg. 10, p. 156, pl. 3, fig. 24.

Test biserial, elongate, about three times longer than broad and twice as broad as thick, much compressed, some specimens slightly to moderately twisted; lateral peripheries acute perpendicular to, and smooth to dentate parallel to, the axis of elongation; dentate projections are the extended peripheral basal margins of chambers and occur sporadically at any level of the test, usually more abundant in early part but occur up to the final chamber in some larger specimens; chambers distinct, slightly inflated, oblique, slightly overlapping, increase regularly in size as added; sutures distinct, slightly depressed, slightly limbate, nearly straight in early part, become slightly curved and sometimes deflected in later chambers of larger specimens, lie at an angle of approximately $45^{\circ}$ to the axis of elongation; wall smooth, perforations of moderate size; aperture elongate, elliptical, becomes terminal and free of the basal suture in some larger specimens, nearly bisected by a thin, recessed, often obscure toothplate which arises at the upper margin of the apertural periphery and extends into the chamber. Dimensions of averaged-sized specimens : length, 0.4 to $0.45 \mathrm{~mm}$; breadth, 0.15 to 0.2 $\mathrm{mm}$; thickness, 0.05 to $0.1 \mathrm{~mm}$.

Remarks.-Most of the specimens have made little progress toward becoming uniserial, but several larger specimens have the aperture free in the apertural face of the final chamber. Details of toothplate structure are obscure because of its extremely small size.

Occurrence.-Bolivina decurrens is a widely reported species though it is not very common in the Cretaceous of America. Cushman (1946, p. 127) reported it from beds of Navarro age in Mississippi and Texas and noted its possible occurrence in the Upper Cretaceous of Venezuela. It has also been reported from the Arkadelphia Marl of Navarro age in Arkansas (Cushman, 1949, p. 9), from the Upper Cretaceous of Maryland (Cushman, 1948a, p. 262) and questionably from the Cretaceous of California (Cushman and Campbell, 1935, p. 73). Elsewhere, this species has been reported from the Upper Cretaceous of Germany, Czechoslovakia, the U.S.S.R., Israel, Denmark, Poland (Maestrichtian), and the Netherlands.

$B$. decurrens occurs in the upper part of the Pierre Shale from just below the upper key bentonite to 103 feet below the lower key bentonite.
Material. -600 to 800 specimens were found.

\begin{tabular}{|c|c|c|c|}
\hline Locality & Sample & Locality & Sample \\
\hline $3 \ldots \ldots$ & $18-S$ & $13 \ldots \ldots$ & $23-V R$ \\
\hline \multirow{7}{*}{7} & $19-R$ & $36_{\sim} \ldots$ & $3-\mathrm{S}$ \\
\hline & $21-\mathrm{RC}$ & $37 \ldots$ & $5-X$ \\
\hline & $23-\mathrm{RC}$ & & $6-X$ \\
\hline & 25-R R & & $10-X$ \\
\hline & $27-V R$ & $39 \ldots \ldots$ & $1-V R$ \\
\hline & $29-X$ & $41 \ldots$ & $1-V R$ \\
\hline & $2-R$ & & $9-R$ \\
\hline \multirow[t]{4}{*}{13} & $5 ?-\mathrm{S}$ & & $10-R R$ \\
\hline & $14-X$ & $42 \ldots$ & $8-\mathrm{C}$ \\
\hline & 20-RC & 44 & $1 \mathrm{~A}-\mathrm{R} R$ \\
\hline & $21-S$ & & \\
\hline
\end{tabular}

Genus LOX0sT0MA Ehrenberg, 1854

Loxostoma gemma (Cushman)

Plate 9, figures $7 a, b$

Bolivina gemma Cushman, 1927, Cushman Lab. Foram. Research Contr., v. 2, pt. 4 , p. 87 , pl. 12, fig. 3.

Loxostoma gemmum (Cushman). Cushman, 1937, Cushman Lak. Foram. Research Spec. Pub. 9, p. 172, pl. 20, figs. 14-16.

Test biserial throughout, elongate, robust, 2 to $21 / 2$ times longer than broad, compressed, a few specimen? twisted, lateral peripheries subacute perpendicular tc. and straight to slightly undulatory parallel to, the axis of elongation; chambers distinct, numerous, increas? regularly in length, breadth, and height as added; inflation of chambers not characteristic but may be present to a slight degree; sutures distinct, slightly to moderately limbate, flush with the surface toward the periphery in larger specimens, inner part often raised into teardrop-shaped prominences of clear shell material which form a zigzag pattern across the central axis, usually developed in the first one-half to two-thirds of the test; wall thick, smooth except for the sutural prominences; aperture oval, elongate in the plane of compression, extends from near the base of the low apertural face to the highest point of the test, bisected by a toothplate which arises at the middle of the upper apertural margin and plunges into the chamber as it proceeds downward toward the basal margin of tha aperture; one side remains free within the aperture and the other side is attached within the chamber beneath the apertural margin on either the right or left side to form a troughlike structure directed into the chamber at an obliquely downward-plunging angle. Dimension* of average-sized specimens: length, about $0.6 \mathrm{~mm}$; breadth, about $0.25 \mathrm{~mm}$; thickness, 0.1 to $0.15 \mathrm{~mm}$.

Remarks.-A specific name is more easily attached to these specimens than is a generic name. The zigzag pattern formed by the raised parts of the sutures is characteristic for the species gemma, although tha Pierre specimens are somewhat broader, more robust, 
and less uniserial than the type specimens of the species. The species has frequently been assigned to the genus Bolivina, but the type specimens more closely resemble the generic description of Loxostoma, and for this reason the species is here placed in Loxostoma.

Occurrence.-Loxostoma gemma has been reported from beds of Navarro age in the Cretaceous deposits of the Gulf Coast (Cushman, 1946, p. 129; 1949, p. 9). It has also been reported from the late Campanian of Israel.

In the upper part of the Pierre Shale. L. gemma occurs 66 to 126 feet below the lower key bentonite.

Material. -400 to 500 specimens were found.

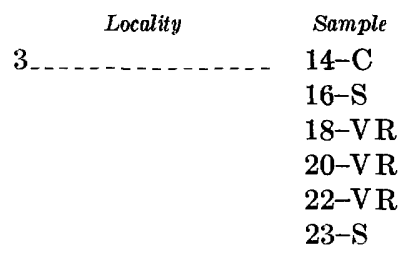

Loxostoma plaita (Carsey)

Plate 9, figures $9 a, b ; 10 a-d$

Bolivina plaita Carsey, 1926, Texas Univ. Bull. 2612, p. 28, pl. 4, fig. 2.

Loxostoma plaitum (Carsey). Cushman, 1931, Tennessee Div. Geology Bull. 41, p. 51, pl. 8, fig. 9.

Test biserial throughout, elongate, $21 / 2$ to four times as long as broad, moderately compressed, lateral peripheries closely rounded perpendicular to, and straight to slightly undulose parallel to, the axis of elongation, occasional specimens slightly twisted in early part; chambers distinct, numerous, increase rather regularly in size and breadth as added, except for the last few chambers in large specimens, which are more inflated and which tend to become uniserial; the final chamber of larger specimens often crosses nearly the entire breadth of the test; sutures distinct, slightly limbate, slightly depressed, where opposed chambers make contact with one another a triangular open area is usually formed which is filled with imperforate shell material; wall thick, finely perforate, smooth; aperture ovate, wider part at the top, reaches to the base of the apertural face in smaller specimens but generally does not in large specimens, where it tends to become terminal; in wellpreserved specimens a toothplate extends into the aperture from its upper end but does not extend to the opposite periphery; it nearly bisects the aperture and loops to either the left or right side to join the undersurface of the final chamber. Dimensions of average-sized specimens: length, about $0.45 \mathrm{~mm}$; breadth, about $0.15 \mathrm{~mm}$; thickness, 0.05 to $0.1 \mathrm{~mm}$.

Remarks.-The Pierre specimens are closely similar to topotype specimens of Loxostoma plaita from the
Navarro Formation on Onion Creek, Travis County, Tex. (Cushman colln. 40316, 6105, 31474). Other specimens seen in the U.S. National Museum collections are slightly narrower, on the average, than the Pierre specimens and have generally gone farther toward becoming uniserial.

Occurrence.-Loxostoma plaita has been widely reported from the Cretaceous. In the Gulf Const deposits of the United States, it occurs in beds of A.ustin, Taylor, and Navarro ages (Cushman, 1946, p. 130; 1949, p. 9). In the Cretaceous deposits of the western interior, it occurs in the Pierre Shale of Nebraska (Loetterle, 1937, p. 61) and in the Hilliard Shale of Wyoming (Gauger, in Jones, 1953, p. 79). Wickenden (1945, p. 42) reported this species from the Boyne Member of the Vermilion River Formation in Saskatchewan and Manitoba, Canada, and Bandy (1951, p. 511) reported it from the Upper Cretaceous of California. Other American Upper Cretaceous occurrences are from the Georges Bank canyons (Cushman, 1936, p. 419), the Hammond well in Maryland (Cushman, 1948a, p. 262), and the Mt. Laurel and Navesink Formations of New Jersey (Jennings, 1936, p. 31). Elsewhere L. plaita has been reported from the Upper Cretaceous of Colombia, the U.S.S.R., and Egypt.

In the upper part of the Pierre Shale this species occurs from 115 feet above the upper key bentonite to 70 feet below the lower key bentonite and is doubtfully identified from a sample 76 feet below the lower key bentonite.

Material.-Several thousand specimens were found.

\begin{tabular}{|c|c|c|c|}
\hline \multirow{2}{*}{$\begin{array}{c}\text { Locality } \\
5\end{array}$} & Sample & Locality & Sample \\
\hline & $4-\mathrm{C}$ & $27 \mathrm{~A}_{\ldots} \ldots$ & $2-\mathrm{S}$ \\
\hline \multirow{6}{*}{5} & $5 ?-\mathrm{S}$ & & $3-\mathrm{VR}$ \\
\hline & $15-V R$ & & $9-\mathrm{RC}$ \\
\hline & $16-R$ & & $11-\mathrm{VR}$ \\
\hline & $17-V R$ & & $15 ?-\mathrm{S}$ \\
\hline & 23-RR & $36 \ldots \ldots$ & $2-X$ \\
\hline & $25-\mathrm{S}$ & & $3-S$ \\
\hline $11 \ldots$ & $3-X$ & & $4 ?-\mathrm{S}$ \\
\hline \multirow[t]{8}{*}{$13_{-}$} & $1-X$ & 37 & 5-VR \\
\hline & $3-\mathrm{S}$ & & $6-\mathrm{R}$ \\
\hline & $5-\mathrm{S}$ & & $10-\mathrm{VR}$ \\
\hline & 9-RR & 39 & $1-\mathrm{RR}$ \\
\hline & $23-V R$ & $41 \ldots$ & $1-V R$ \\
\hline & $40-C$ & & 9-VR \\
\hline & $41-\mathrm{RC}$ & & $10-V R$ \\
\hline & $43-\mathrm{R}$ & $42 \ldots$ & $8 ?-\mathrm{X}$ \\
\hline \multirow[t]{3}{*}{20} & $5-\mathrm{C}$ & $44 \ldots$ & 6-RR \\
\hline & $11-\mathrm{A}$ & & $8-\mathrm{RC}$ \\
\hline & $17-\mathrm{R} R$ & & $17 ?-\mathrm{C}$ \\
\hline \multirow{6}{*}{$27 \ldots$} & $1-\mathrm{C}$ & & $21-\mathrm{RC}$ \\
\hline & $3-\mathrm{C}$ & & $23-\mathrm{C}$ \\
\hline & $4-\mathrm{VC}$ & $45 \ldots \ldots$ & 1-VR \\
\hline & $6-\mathrm{C}$ & & $3-X$ \\
\hline & $7-\mathrm{VC}$ & & $7-\mathrm{C}$ \\
\hline & $9-\mathrm{C}$ & $49 \ldots \ldots$ & $\begin{array}{l}15-\mathrm{RC} \\
10-\mathrm{BR}\end{array}$ \\
\hline
\end{tabular}




\section{?Loxostoma plaita (Carsey)}

Plate 1, figures $8 a, b$

Test biserial, elongate, slender, tapers toward proximal end, compressed, not twisted, tends to become somewhat uniserial in last part of largest specimens; chambers numerous, slightly inflated, increase regularly, but more in height than in breadth, as added; sutures distinct, depressed, straight to slightly curved in early part, more strongly curved in later part; features of the wall and aperture indeterminate. Dimensions of average-sized specimens: length, 0.25 to $0.3 \mathrm{~mm}$; breadth, about $0.1 \mathrm{~mm}$; thickness, about $0.05 \mathrm{~mm}$.

Remarks.-Many specimens are available at some horizons, but none exhibits the calcareous wall which was presumably originally present. The specimens are believed to be remarkably well-preserved internal molds of Loxostoma plaita. The pyrite-filled shell of a specimen of L. plaita was dissolved away with acid, and the resulting internal mold closely resembles the specimens here designated as ?L. plaita except in size. The internal molds are consistently smaller than the average size of L. plaita from the Pierre samples. The presence of both ?L. plaita and shelled L. plaita in the same sample suggests that the differences between them may be of genetic rather than environmental origin.

Specimens apparently similar both in manner of preservation and in morphology to those described here were reported by Young $(1951$, p. 64$)$, who called them Loxostomum tequlatum (Reuss). In my opinion, this identification, based, as it apparently was, on internal molds only, must be regarded as less certain than Young has indicated.

Occurrence.-These specimens occur from 72 feet above to 20 feet below the upper key bentonite.

Material.-Several hundred specimens were found.

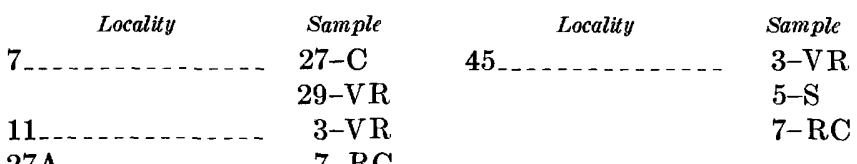

Genus STILOSTOMELLA Guppy, 1894

Stilostomella pseudoscripta (Cushman)

Plate 9, figures 11a, b

Ellipsonodosaria pseudoscripta Cushman, 1937, Cushman Lab. Foram. Research Contr., v. 13, pt. 4, p. 103, pl. 15, fig. 14 . Siphonodosaria pseudosaripta (Cushman). Stainforth, 1952a, Cushman Found. Foram. Research Contr., v. 3, pt. 1, p. 13.

Test uniserial, elongate, cylindrical, straight or very slightly curved, tapers; chambers slenderer and more numerous per unit length in microspheric as opposed to megalospheric specimens, increase in diameter and height of chambers as added is approximately the sane in both forms, a usually rather long acerose spine of clear shell material extends from the base of the test in most specimens; chambers distinct, inflated, early chambers globular, later chambers gradually increase in relative length, and final chambers may be twice as long as broad, become less closely appressed and more pyriform as added; sutures distinct, slightly depressed in early part, become increasingly more deeply depressed as the chambers are increasingly separated, slightly if at s.ll limbate; wall of the early chambers ornamented by a few downward-pointing spines generally concentrated near the lower edges of the chambers; in later chambers spines are more numerous and are distributed at random over the surface; in final chambers of larger specimens the spines are less stout, more numerous, and are pointed down at a lesser angle than previously; aperture subrounded to circular, raised on a short, stout nesk and ringed by a thick lip which is radially grooved in some specimens, some specimens with a small tonguelike projection extending into the aperture from the rim. Dimensions of average-sized specimens: length (exclusive of basal spine), 0.55 to $0.6 \mathrm{~mm}$; breadth, 0.05 to $0.1 \mathrm{~mm}$.

Remarks.-Microspheric and magalospheric individuals are distinguished on the basis of the size of the proloculus, which in microspheric specimens is only onehalf to two-thirds the size of the megalospheric proloculus. None of the specimens shows any sign of biseriality in the early stages. Ten of the best preserved specimens were examined in an effort to see whether or not a tooth was present in the aperture. Two specimens exhibited a funnellike structure leading from the innor rim of the lip to an irregularly shaped and quite small opening at the center. One large specimen had a welldeveloped tooth extending into the aperture, and each of two others had a less well-developed tooth. The remaining five specimens exhibited approximately circular apertures, the diameters of which varied considerably from specimen to specimen relative to the diameters of the apertural necks.

An examination of the holotype and paratypes of Stilostomella minuta (Cushman), which the Pierre specimens resemble rather closely, revealed that the first few chambers are costate rather than spinose. The typas of Stilostomella pseudoscripta (Cushman) were also examined and are uniserial throughout and show no sign of an initial biserial stage. They are not as well preserved as the Pierre specimens and have only the suggestion of a basal spine, but other specimens of Stitostomella pseudoscripta in the U.S. National Museum collections clearly show a basal spine exactly like that exhibited by the Pierre specimens. 
FORAMINIFERA, STRATIGRAPHY, PIERRE SHALE, FOX HILLS SANDSTONE, S. DAK.

This species was originally placed in the genus Ellipsonodosaria Silvestri by Cushman (1937, p. 103). Stainforth (1952a, p. 13) placed the species in the genus Siphonodosaria Silvestri and placed this genus in the family Buliminidae. Shortly thereafter, Stainforth (1952b) called attention to the fact that Finlay (1947, p. 275) had placed Siphonodosaria in synonymy with the genus Stilostomella Guppy, an assignment which Stainforth stated "** *" appears to be correct." Finlay had placed the genus Stilostomella in his new subfamily Stilostomellinae of the family Lagenidae. The radiate grooves in the apertural lip and the elongate uniserial nature of the test exhibited by Stilostomella pseudoscripta seem to be more in character with the family Lagenidae than with the family Buliminidae. However, in view of the broader scope and more exhaustive nature of Stainforth's study of this and related species, his assignment of the genus Stilostomella to the Buliminidae is accepted here.

Occurrence.-Stilostomella pseudoscripta was recorded by Cushman (1946, p. 135), under the generic name El7ipsonodosaria, from beds of Austin, Taylor, and Navarro ages from the Gulf Coastal Plain deposits. The only reference to this species away from the Gulf Coast area is from beds of Campanian and Maestrichtian ages in Angola.

In the upper part of the Pierre Shale this species occurs from 46 feet above the upper key bentonite to 103 feet below the lower key bentonite.

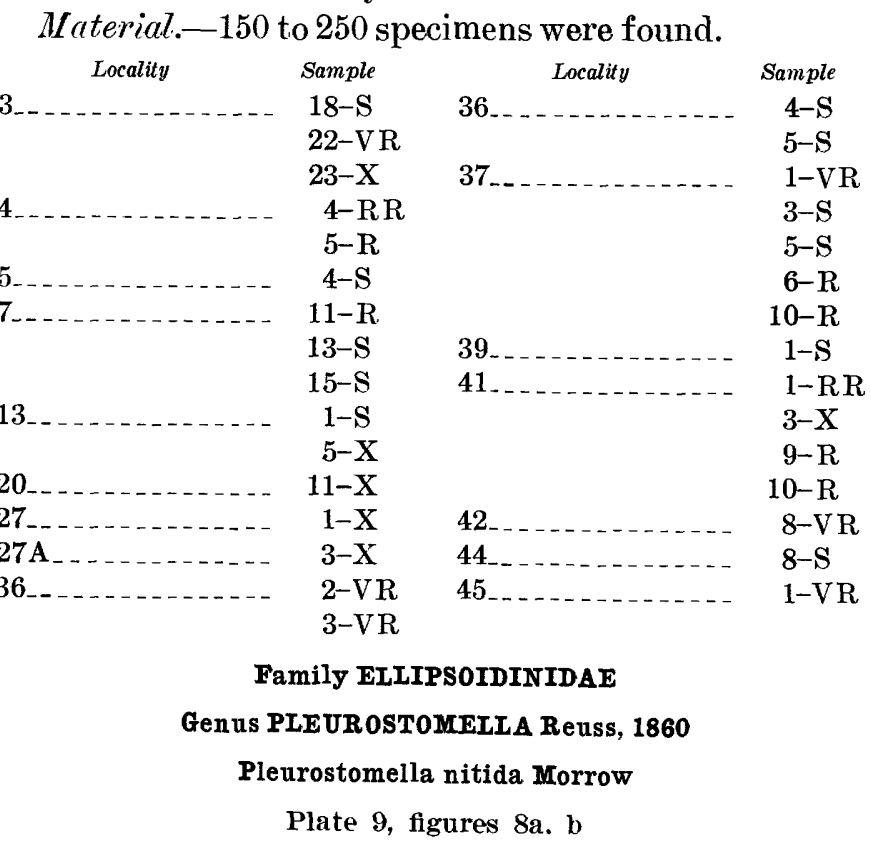

Pleurostomella nitida Morrow, 1934, Jour. Paleontology, v. 8, No. 2 , p. 196, pl. 30, fig. 22.

Test loosely biserial, elongate, slightly if at all compressed laterally, sides taper slightly to a bluntly rounded initial end, slightly twisted along the axis; chambers few, no more than nine in the Pierre specimens, inflated, overlapping, later chambers considerably larger; sutures distinct, depressed; wall smoth, finely perforate; aperture a high-arched opening oblique to the axis of elongation of the test, occupying the upper onethird of the final chamber, basal margin of tha aperture has a pair of small sharp projections extending upward, one on each side of a small crescent-shaped ir dentation in the margin; rim of upper arch-shaped part of apertural margin slightly thickened. Dimensions of averagesized specimens: length, 0.25 to $0.3 \mathrm{~mm}$; breadth, about $0.1 \mathrm{~mm}$; thickness, about $0.1 \mathrm{~mm}$.

Remarks.-Morrow (1934, p. 196), in his original description of Pleurostomella nitida, stated that the aperture was “*** apparently not toothed." Carefvl reexamination of the holotype of $P$. nitida, the only specimen of the species in the U.S. National Museum collections, showed that the aperture is partly filled. The holotype was coated with glycerin in an effort to elucidate internal and apertural detail. Under glycerin, two apertural projections very similar to those in the Pierre specimens can be seen. The Pierre specimens are also similar to the holotype in chamber arrangement and test shape, except that they are slightly twisted about the axis of elongation instead of being straight. Under glycerin, the holotype was also seen to have an internal tube extending between apertures, but it was impossible to determine the presence or absence of this structure in the Pierre specimens because of the opacity of the test walls and the presence of pyrite within the chambers.

The Pierre specimens resemble $P$. torta Cushman in having a slightly twisted axis but differ in being much smaller and in having two pointed apertural projections. P. obtusa Berthelin apparently has a round aperture, and no mention of teeth was made in the type description. P. elliptica Galloway and Heminway has a lunate aperture with two small pointed teetr but differs in not being twisted, in being much larger, and in having a relatively smaller aperture with teeth spaced closer together.

Occurrence.-Pleurostomella nitida has only been reported twice, to the best of my knowledge. Morrow originally described the species from the Greenhorn Limestone and Niobrara Formation of Kansas, and Cushman (1946, p. 132) reported it from the Austin Chalk of Texas.

In the upper part of the Pierre Shale, specimens of this species occur from the level of the lower key bentonite to 115 feet below this level. 
Material.-Fewer than 20 specimens were found.

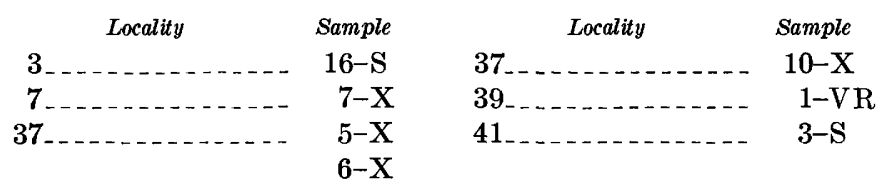

Genus ELLIPSOGLANDULINA A. Silvestri, 1900

Ellipsoglandulina sp.

Remarks.-Only two poorly preserved specimens referable to this genus were found. In outline and chamber arrangement these specimens seem to correspond most closely to Ellipsoglandulina feifeli Franke, which was originally described from the Lias of Germany (Franke, 1936, p. 60, pl. 6, fig. 6) but which has not been reported from the Cretaceous.

Occurrence.-These specimens occur within 150 feet below the level of the lower key bentonite.

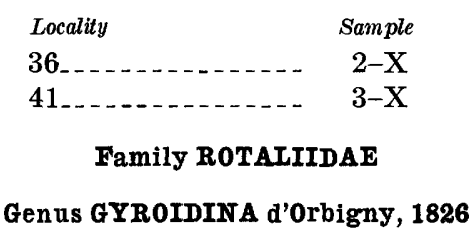

Gyroidina depressa (Alth)

Plate 10, figures $2 a-C$

Rotalina depressa Alth, 1850, Haidinger's Naturw. Abh., v., 3 , p. 266, pl. 13, fig. 21.

Gyroidina depressa (Alth). Cushman and Church, 1929, California Acad. Sci. Proc., 4th ser., v. 18, no. 16, p. 515, pl. 41, figs. 4-6.

Test low trochospiral, biconvex, umbilical side more deeply convex, in some specimens spiral side nearly flat, axial periphery rounded to slightly angled, equatorial periphery slightly lobulate, umbilicus small, shallow, occasional larger specimens with short extensions of the apertural lip into the umbilicus; chambers fairly distinct in most specimens, usually nine to 11 in final whorl, generally not inflated; sutures distinct in well-preserved specimens, limbate, flush with the surface on both sides, slightly curved to nearly radial on umbilical side, less limbate and gently curved on spiral side; wall smooth, finely perforate; aperture an interiomarginal slit extending from the periphery to the umbilicus, may extend a very short distance over the periphery onto the spiral side, with a slight lip above the aperture which on several specimens develops into a short, flat, tonguelike plate that extends into the umbilicus. Dimensions of average-sized specimens: maximum diameter, about $0.25 \mathrm{~mm}$; minimum diameter, about $0.2 \mathrm{~mm}$; thickness, about $0.1 \mathrm{~mm}$.

Remarks.-A group of 27 specimens of this species, chosen at random from locality 27 , sample 6 , were stud- ied to determine the ranges of variation of various morphologic characters. The results are summarized below :

1. The number of chambers in the final whorl varies from 8 to $123 / 4$, the average being about 10 . There is a slight increase in the average number of chambers in the final whorl as diameter increases.

2. The percentage of the total diameter represented by one whorl (determined by dividing greatest diameter by number of whorls), as measured from the spiral side, ranges from 5 to 29 percent, the average being between 20 and 25 percent, with no consistent change related to increase in greatest diameter of the test.

3. The ratio of increase between greatest and least diameter is about $1: 1$, most specimens being quite. near the average.

4. Thickness and greatest diameter increase in about a 1: 2 ratio. Thickness expressed as a percentage of the greatest diameter ranges from 50 to 26 percent for specimens with greatest diameters in the range. of $0.15 \mathrm{~mm}$ to $0.315 \mathrm{~mm}$, the average being about 40 percent. Thickness is only 24 to 29 percent of. greatest diameter in the six specimens with greatest diameters of $0.33 \mathrm{~mm}$ to $0.46 \mathrm{~mm}$.

An umbilical flap is present in almost every specimer larger than $0.24 \mathrm{~mm}$ in greatest diameter and extends from the base of the final chamber into the umbilicus Smaller specimens generally lack this structure. The aperture, an interiomarginal slit, may extend from the base of the final chamber on the spiral side to the umbilicus but is usually confined to the umbilical side. The usual apertural slit is supplemented in a very few specimens by a small arching of the upper margin of the aperture. This small arched part of the aperture is somewhat recessed into the apertual face.

The apertural face of the final chamber varies in the nature of its periphery and in the amount of perforation. In most specimens, the periphery of the apertural face is smoothly rounded, and the face itself is as perforate or nearly as perforate as the rest of the test. However, some specimens have a ridge, presumably the foundation of a chamber never completed, which forms the periphery of the apertural face. In all such specimens studied, the perforations seem to be either markedly fewer of absent altogether, with the result that the apertural face is much more transparent than the remainder of the test.

Three topotypes of Gyroidina depressa, from the Mucronaten Kriede, Lemberg (L'vov), U.S.S.R., were available for comparison. These specimens (Cushman colln. 16245), which are not well preserved, differ from the Pierre specimens referred to $G$. depressa 
FORAMINIFERA, STRATIGRAPHY, PIERRE SHALE, FOX HILLS SANDSTONE, S. DAK.

in being larger than the average, though not larger than the largest, of the Pierre specimens, in being less convex on the spiral side, and in apparently having coarser perforations. Comparison of the topotypes with plesiotypes of $G$. depressa from the Gulf Coast Cretaceous reveals that the Gulf Coast specimens, like the Pierre specimens, are more convex on the spiral side and are less coarsely perforate. Most of the Gulf plesiotypes approximate the size of the topotypes, but most have a pronounced buttonlike umbilical flap that fills or nearly fills the umbilicus, unlike the topotypes, which do not seem to have any umbilical flap, and unlike the Pierre specimens, the larger of which have generally smaller umbilical flaps.

The Pierre specimens differ noticeably from specimens described and illustrated in various publications by Cushman from the Marlbrook Marl, Austin Chalk, Arkadelphia Marl, Brownstown Marl, Corsicana Marl, Larry G. Hammond well 1 (sample from 1450-1470 ft), and Selma Group only in lacking as prominent an umbilical flap or plug.

In summary, the Pierre specimens closely resemble $G$. depressa of Cushman from the American Cretaceous. Neither the Pierre specimens nor those of Cushman seem to me to resemble the topotypes very closely. However, Cushman (1946, p. 139) noted that "*** the common American species seems to be the same (as the topotypes of $G$. depressa), although subject to considerable variation in number of chambers, degrees of openness of the umbilicus, and convexity of the test." Subsequent study may reveal that the American material, including the Pierre specimens, referred to G. depressa (Alth) is better accommodated within a different species.

The specimens with which the Pierre specimens of $G$. depressa were compared and to which they are closely similar are illustrated in the following places : Cushman (1949, p. 9, pl. 4, figs, 12, 13) ; Cushman and Deaderick (1944, p. 339, pl. 53, figs. 19, 20) ; Cushman (1944b, p. 95, pl. 14, fig. 23) ; Cushman (1948a, p. 264, pl. 25, fig. 18) ; Cushman (1931b, p. 311, pl. 36, fig. 2a-c).

Occurrence.-Gyroidina depressa (Alth) is a very widely reported species both in the Cretaceous of the United States and of the world. Cushman (1946, p. 139) reported it from beds of Austin, Taylor, and Navarro ages and from the Eagle Ford Shale in the Upper Cretaceous of the Gulf Coastal Plain. In the Upper Cretaceous of the western interior and the contiguous Canadian Upper Cretaceous, it has been reported from the Alberta Shale of Alberta (Wickenden, 1932b, p. 206); with question from the Boyne Member of the Vermilion River Formation of Saskatchewan and Manitoba (Wickenden, 1945, p. 42); from the Pierre Shale of South Dakota (Applin, 1933, p. 219; Searight, 1938, p. 135) ; from the Niobrara Formation and P:arre Shale of South Dakota, Nebraska, and Kansas (Loetterle, 1937, p. 42) ; from th Niobrara Formation of South Dakota (Bolin, 1952, p. 52) and Wyoming (Khaw, 1953, p. 50); and from the Hilliard Shale of Wyoming (Gauger, in Jones, 1953, p. 80-81). Other Arnerican occurrences have been reported from the Upper Cretaceous of California (Cushman and Church, 1929, p. 515), the Georges Bank canyons (Cushman, 1936, p. 419), and Maryland (Cushman, 1948a, p. 264), with a tentative identification from the Cenomanian of California (Church, 1952, p. 70). This species has alro been reported from the Upper Cretaceous of Venezuela, Cuba, Colombia, Trinidad, Mexico, the U.S.S.R., Bulgaria, Poland, Germany, the Netherlands, South $A$ frica, and tentatively from the Upper Cretaceous of Fiance.

In the upper part of the Pierre Shale, $G$. depressa is found from 174 feet below the lower key bentonite to 71 feet above the upper key bentonite.

Material. $-2,000$ to 3,000 specimens were found.

\begin{tabular}{|c|c|c|c|}
\hline \multirow{3}{*}{$\begin{array}{c}\text { Locality } \\
1\end{array}$} & Sample & Locality & Sample \\
\hline & $5 ?-X$ & $13 \ldots \ldots$ & $40-V R$ \\
\hline & $12-\mathrm{VR}$ & & $41-R$ \\
\hline & $14-R$ & & $43-S$ \\
\hline & $16-V R$ & 20 & $5-\mathrm{C}$ \\
\hline & $18-\mathrm{RC}$ & & $11-\mathrm{R}$ \\
\hline & $20-\mathrm{RC}$ & & $17-\mathrm{R}$ \\
\hline & $22-\mathrm{R} \mathrm{R}$ & $27 \ldots$ & $1-C$ \\
\hline & $23-\mathrm{RC}$ & & $3-\mathrm{C}$ \\
\hline$\ldots \ldots$ & 4-A & & $4-R R$ \\
\hline & 5-A & & $6-\mathrm{C}$ \\
\hline 5 & $4-R$ & & 7-RC \\
\hline & $5-\mathrm{R}$ & & $9-\mathrm{RC}$ \\
\hline$-\ldots$ & $1-\mathrm{S}$ & $27 \mathrm{~A}_{-}$ & $2-\mathrm{RR}$ \\
\hline & $5-\mathrm{RC}$ & & 3 -VR \\
\hline & $6-X$ & & $7 ?-\mathrm{S}$ \\
\hline & $7-X$ & $36 \ldots$ & $1-R R$ \\
\hline & $11-R C$ & & $2-\mathrm{RR}$ \\
\hline & 13-RC & & $3-R R$ \\
\hline & $15-\mathrm{RR}$ & & 4-RR \\
\hline & $16-R R$ & & $5-\mathrm{R}$ \\
\hline & $17-\mathrm{RC}$ & $37_{\ldots} \ldots$ & $1-R R$ \\
\hline & $19-\mathrm{S}$ & & $3-R R$ \\
\hline & $21-R R$ & & $5-\mathrm{RC}$ \\
\hline & $23-\mathrm{RC}$ & & $6-\mathrm{C}$ \\
\hline & $25-\mathrm{VR}$ & & $10-\mathrm{RC}$ \\
\hline & $29-\mathrm{S}$ & & $12-\mathrm{VR}$ \\
\hline & $30-\mathrm{RC}$ & $39 \ldots$ & $1-R R$ \\
\hline & $32-\mathrm{R}$ & $41 \ldots$ & $1-V R$ \\
\hline$\ldots$ & $3-\mathrm{S}$ & & $3-R R$ \\
\hline 13 & $1-V R$ & & 5 -VR \\
\hline & $3-R$ & & $9-\mathrm{RC}$ \\
\hline & $5-\mathrm{RR}$ & & $10-\mathrm{RC}$ \\
\hline & $9-\mathrm{RR}$ & $42 \ldots$ & $8-R$ \\
\hline & $10-S$ & $44_{-\ldots}$ & $1 \mathrm{~A}-\mathrm{V} \mathrm{R}$ \\
\hline & $12-\mathrm{X}$ & & 8-VR \\
\hline & $14-X$ & $45_{-}$ & $1-\mathrm{RC}$ \\
\hline & $16-X$ & & $3-R$ \\
\hline & $20-\mathrm{R} R$ & & $5-X$ \\
\hline & $23-\mathrm{S}$ & & $7-\mathrm{RC}$ \\
\hline
\end{tabular}



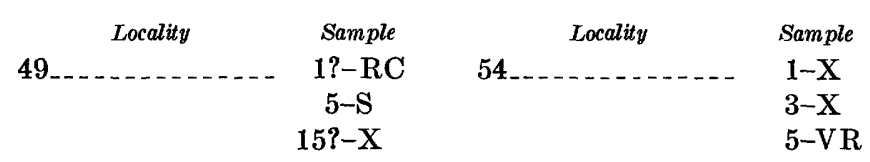

"Gyroidina globosa (Hagenow)" of Cushman

Plate 10, figures 1a-c

Gyroidina globosa Cushman, 1931 (not Hagenow, 1842), Jour. Paleontology, v. 5, no. 4, p. 310, pl. 35, fig. 19.

Cushman and Deaderick, 1944, Jour. Paleontology, v. 18, p. 339, pl. 53, figs. 21, 22.

Cushman, 1944, Cushman Lab. Foram, Research Contr., v. 20 , pt. 1, p. 13, pl. 3, fig. 3.

Cushman, 1948, Maryland Dept. Geology, Mines and Water Resources Bull. 2, p. 264, pl. 25, figs, 15, 16.

Not Rotalia globosa (Hagenow). Reuss, 1861 (1862). Akad. Wiss. Sitzungsber, v. 44, pt. 1, pl. 7, fig. 2.

Not Discorbina globosa (Hagenow). Marsson, 1878, Naturw. Versteinerungen Neu-Vorpommern u. Ruigen Mitt., Jahrg. 10, p. 163-164, pl. 4, fig. 32 .

Not Rotalia globosa (Hagenow). Franke, 1928, Preussische Geol. Landesanstalt Abh., new ser., no. 3, p. 187-188, pl. 17, fig. 12.

Not Gyroidina globosa (Hagenow). Gandolfi, 1942, Riv. Italiana Paleontol., v. 48, 1942-XX, Mem. IV, p. 95, fig. 31.

Test trochoid, spiral side partially evolute and slightly convex, umbilical side completely involute and deeply convex; umbilicus small, shallow; axial periphery rounded, equatorial periphery smooth; chambers quite distinct on both sides, little if at all inflated, increase gradually in size as added, six to eight in the final whorl; sutures fairly distinct, slightly depressed on umbilical side, more deeply depressed on spiral side, straight and radial on umbilical side, slightly oblique and curved on spiral side; wall smooth, finely perforate; aperture an interiomarginal slit extending from the periphery to the umbilicus, with a small lip above, which, in some specimens, flares out slightly into a tonguelike lobe which plunges into or extends across the small umbilicus. Dimensions of average-sized specimens : maximum diameter, about $0.2 \mathrm{~mm}$; minimum diameter, about $0.15 \mathrm{~mm}$; thickness, 0.1 to $0.15 \mathrm{~mm}$.

Remarks.-The most characteristic features of these specimens are the globular appearance, the indentation of the sutures in the last half of the final whorl on the spiral side, and the small shallow umbilicus with the occasional extension of the apertural lip into it.

The Pierre specimens are exactly similar in size and morphology to the following plesiotypes, labeled Gyroidina globosa, from the U.S. National Museum collections. The lithologic unit, general locality, reference, and slide number are given.

\begin{tabular}{|c|c|c|}
\hline Stratigraphic designation & General locality & Slide \\
\hline \multicolumn{3}{|l|}{ Plesiotypes } \\
\hline Saratoga Chalk '_....... & Saratoga, Ark & 15625 \\
\hline Marlbrook Marl 2_...... & $\begin{array}{l}2 \text { miles east of Saratoga, } \\
\text { Ark. }\end{array}$ & 41978 \\
\hline $\begin{array}{l}\text { Pecan Gap Chalk Mem- } \\
\text { ber of Taylor Marl. }{ }^{3}\end{array}$ & $\begin{array}{l}1 / 2 \text { mile east of Pecan Gap, } \\
\text { Delta County, Tex. }\end{array}$ & 40247 \\
\hline$\left.{ }^{4}\right) \ldots \ldots$ & $\begin{array}{l}\text { Sample from 1450-1470 } \\
\text { feet, Hammond well } \\
\text { No. 1, Salisbury, Md. }\end{array}$ & 62296 \\
\hline
\end{tabular}

1 Cushman (1931b, pl. 35, figs. 19a-d).

a Cushman and Deaderick (1944, pl. 53, figs. 21, 22).

3 Cushman (1944a, pl. 3, fig. 3).

Other specimens labeled $G$. globosa and considered to be conspecific with the Pierre specimens occur in samples from the following lithologic units:

\begin{tabular}{|c|c|}
\hline Iithologic unit & Cushman collection slide \\
\hline Neylandville Marl $\ldots \ldots \ldots$ & 33693 \\
\hline Upper part of the Taylor Marl & $\begin{array}{l}33716,33719,33699, \\
\quad 33696,33728,33700\end{array}$ \\
\hline
\end{tabular}
stone.

Pecan Gap Chalk Member of the 40248, 40246, 33705, Taylor Marl. $33706,33708,33704$, 33695

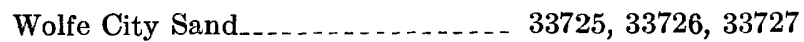

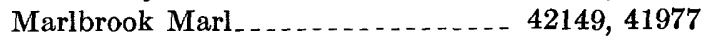

Annona Chalk ........ . . . . . . . . 33720

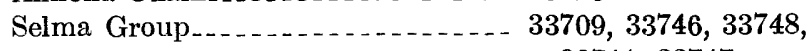

33711,33747

Middle part of the Taylor Marl _. _ 33717

Taylor Marl (undifferentiated) _.... 33697, 33702, 33692, 33690

Saratoga Chalk

Ozan Formation ............... 33721

Lower part of the Taylor Marl _. _. 33734, 33714, 33712, $33737,33691,33698$

Gober Tongue of the Austin Chalk_- 33713, 33733, 33740, 33732

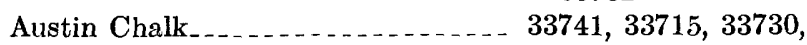
33729,33731

Larry G. Hammond well 1, Salis- $\quad 62295(1423-1433 \mathrm{ft})$, bury, Md. $62294(1410-1420 \mathrm{ft})$

Specimens from the formations and localities listed above, and from the upper part of the Pierre Shale, differ markedly from seven topotypes (on two slides) of $G$. globosa (Hagenow). These specimens, from the island of Rügen in Germany, are three to four times larger than the United States specimens, are almost entirely involute on the spiral side and have an aperture that differs in size and shape from that of the American specimens. Specimens on a third slide, also labeled as topotypes from the island of Rügen, are about two-thirds the size of the other topotypes, are not as involute on the spiral side, and have a domed spiral-side surface. 
The most striking characteristic of the seven larger topotypes, aside from size, is the nearly complete coverage of the previous coils on the spiral side by the five to seven chambers of the last whorl. The aperture is a narrow interiomarginal opening recessed in the apertural face of the final chamber and located in the central or central-umbilical part of the apertural face. It occupies one-third to one-half the basal margin of the apertural face. The sutures are radiate on the spiral side, are flush with the surface, and are generally straight, though they may be shightly curved. No umbilical depression exists, and there is no extension of a flap from the final chamber over the umbilical area.

Specimens exactly like both the large and the small topotypes were found in several faunal assemblage slides from the island of Rügen in the U.S. National Museum collections. Small specimens exactly like the larger topotypes were found and thus indicate that the smaller topotypes very probably belong in a separate and distinct species and are not less mature specimens conspecific with the larger topotypes.

Smaller specimens of the smaller topotypes were also compared with specimens of "Gyroidina globosa" from the upper part of the Pierre Shale and Gulf Coast Cretaceous deposits. These agree closely with the American specimens and are considered to belong to the same species. The larger average size of even these smaller topotypes compared with the American specimens is probably due to conditions that promoted larger growth in the Riigen area because most of the specimens of Foraminifera contained on the faunal slides from Rügen are also represented by specimens that are extremely large for their respective genera.

The problem remains which, if either, of these groups of specimens from the island of Rügen may be actual topotypes of Nonionina globosa Hagenow. Hagenow $(1842$, p. 574) gave no type figure and no measurements of his species, and his description does not permit a positive decision to be made. The larger specimens seem the more likely choice, because the type description states that the species is nearly circular, very globularly swollen (Hagenow, 1842, p. 574). There are two other names which must be considered for the smaller "topotypes" and the American specimens. These are $G$. praeglobosa Brotzen and $G$. globosa (Hagenow) var. orbicella Bandy.

G. globosa (Hagenow) var. orbicella Bandy differs from Gyroidina globosa (Hagenow) "**** in that it is not as thick and the apertural face is comparatively much higher and not as broad as in Hagenow's specimens" (Bandy, 1951, p. 505). This variety also differs in these respects from the specimens from the Gulf Coastal Plain and from the upper part of the Pierre
Shale and cannot be considered to inchide these specimens. The American specimens seem to resemble $G$. praeglobosa Brotzen more closely but differ in lacking a strongly oblique apertural face. Comparison with a plesiotype of $G$. globosa (Cushman and Jarvis, 1932, pl. 14, fig. 4), which was placed in synonymy by Brotzen under $G$. praeglobosa, reveals that the American specimens are slightly less deep on the umbilical side and in general have more acutely angled axial peripheries.

It is concluded, therefore, that the Pierre specimens are different from $G$. globosa (Hagenow) var. orbicella. Bandy, probably different from $G$. praeglob ssa Brotzen, different from the large "topotypes" from the island of Rügen, and the same as the smaller "topotypes" from this island.

In view of my own uncertainty as to the true nature of $N$. globosa Hagenow, it seems best to refer the American specimens, including those from the upper part of the Pierre Shale, to G. globosa, in the sense in which Cushman conceived of this species, until the characteristics of $N$. globosa Hagenow are clarified by more intensive study of topotype and other specimens.

Occurrence.-The name Gyroidina globosa (Hagenow) has been applied to Foraminifera from beds of Austin, Taylor, and Navarro ages in the Gulf Coast deposits (Cushman, 1946, p. 140), from the Upper Cretaceous of California (Cushman and Goudloff, 1944, p. 61), and from the Upper Cretaceous of Maryland (Cushman, 1948a, p. 264). Other reported occurrences are from the Upper Cretaceous of Colombia, France, Venezuela, Trinidad, Australia, the Maestrichtian of the Netherlands, the Cenomanian of Spain, and the Campanian-Maestrichtian of Mexico.

In the upper part of the Pierre Shale this species is found from 83 feet above the upper key bentonite to 126 feet below the lower key bentonite.

Material.-Fewer than 150 specimens were found.

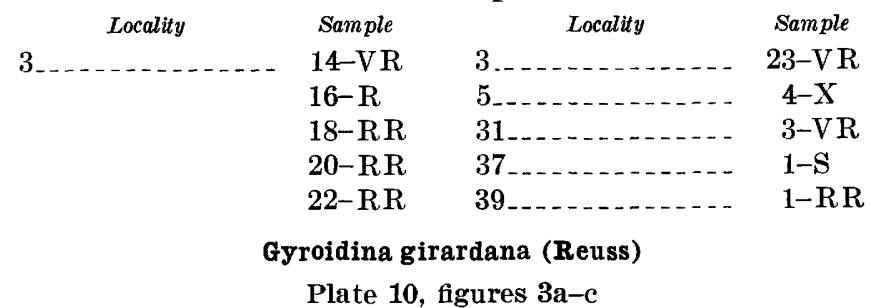

Rotalina giraráana Reuss, 1851, Deutschen Geo'. Gesell. Zeitschr., Berlin, v. 3, p. 73, pl. 5, fig. 34.

Gyroidina girardana (Reuss). Cushman, 1931, Jour. Paleontology, v. 5, p. 311, pl. 36, fig. 1.

Cushman, 1944, Cushman Lab. Foram. Rese $r$ rch Contr., v. 20, pt. 4, p. 95, pl. 4, fig. 24.

Cushman and Renz, 1946, Cushman Lab. Foram. Research Spec. Pub. 18, p. 44, pl. 7, fig. 20.

Test trochoid, composed of 2 to $21 / 2$ whorls, completely involute on umbilical side, evolute on spiral side, 
umbilical side very convex in smaller specimens and becomes subconical in larger specimens, spiral side ranges from slightly convex to slightly concave, umbilicus narrow and shallow in small specimens, becomes progressively deeper as test becomes more conical, axial periphery varies in angularity but in general bluntly angular, equatorial periphery smooth to slightly lobulate; chambers fairly distinct, about 8 in the final whorl, not inflated, increase gradually in size as added, wedge shaped on umbilical side, rhomboid on spiral side; sutures fairly distinct on well-preserved specimens, usually flush with the surface but may be slightly raised in early part, often slightly depressed between final few chambers, slightly limbate, radial or very slightly sinuous on umbilical side, curving and oblique on spiral side; wall smooth, finely perforate; umbilicus usually deep and narrow to moderately wide in larger specimens, closed and dimple shaped in most smaller specimens and some larger specimens; aperture an interiomarginal slit extending from the peripheral angle to the umbilicus, with a slight lip above, which develops into a tonguelike flap which plunges into the umbilicus and in smaller specimens reaches all the way across the umbilicus; in larger specimens several of these flaps can often be seen in the open umbilicus where they resemble steps in a spiral staircase. Dimensions of average-sized specimens: maximum diameter, 0.2 to $0.25 \mathrm{~mm}$; minimum diameter, about $0.2 \mathrm{~mm}$; thickness, 0.1 to $0.15 \mathrm{~mm}$. The ratio of greatest diameter to thickness for six specimens measured ranges from 1.56:1 to $1.99: 1$ and shows no consistent relationship to test size.

Remarks.-The Pierre specimens were compared with two topotypes of Rotalina girardana Reuss and with numerous other specimens of Gyroidina girardana (Reuss) in the U.S. National Museum collections. Comparison was also made with specimens of the closely similar species $G$. subangulata (Plummer), but the Pierre specimens appear to differ consistently from this species in having a slightly more acutely conical umbilical side.

The similarity between $G$. girardana and $G$. subangulata deserves further comment. The topotypes of $G$. gir ardana seem to compare well in most objectively defined characters with the type description of $G$. subangulata. In one of the two topotypes the spiral side (dorsal) sutures are nearly radial, whereas in the other they are slightly to moderately oblique, and the umbilical side (ventral) sutures in both specimens are very slightly curved. According to Plummer's type description, $G$. subangulata has sutures " $* * * *$ moderately oblique dor- sally and radiate ventrally" (Plummer, 1926, p. 154). Comparison of the topotypes of $G$. girardana with specimens labeled G. subangulata (Plummer) in the U.S. National Museum collection revealed one rather consistent difference. Most of the specimens of $G$. subangulata are less acutely conical than the topotypes and other specimens of $G$. girardana. This difference does provide some basis for differentiation between these two species, but it certainly does not clearly separate them. A thorough study of the ranges of variation exhibited by suites of topotypes of these species is needed to clearly define their limits or to establish their identity.

The open umbilicus typically exhibited by specimens here considered to belong in $G$. girardana raises the question of the generic assignment of this species. The genus Gyroidinoides Brotzen was erected to receive forms similar to Gyroidina but differs from it in having open umbilici and apertural lips. Some of the specimens, usually the larger ones, of $G$. girardana, both from the upper part of the Pierre Shale and from the U.S. National Museum collections, possess these structures. However, there is considerable variation in them, ranging from complete absence of an open umbilicus and reduced lip size on some specimens to the presence of a deep moderately wide umbilical opening in which preceding umbilical extensions of apertural lips can be seen. Some of the Pierre specimens of $G$. depressa also have slightly to moderately deep and open umbilical depressions.

In summary, many of the specimens here placed in G. girardana, and some placed in G. depressa (Alth), exhibit characters which have been given generic significance by Brotzen in recognizing the genus Gyroidinoides. Because the variability described above suggests that the characters on which the genus Gyroidinoides is based may be equivocal, at least as applied to the Pierre specimens, I have used the older generic name Gyroidina.

Occurrence.-Gyroidina girardana has been reported from beds of Austin, Taylor and Navarro ages in the Gulf Coast Cretaceous deposits (Cushman, 1946, p. 140), from the Upper Cretaceous of Florida (Cole, 1938, p. 35), and from the Upper Cretaceous of Maryland (Cushman, 1948a, p. 264). It has also been reported from the Uper Cretaceous of France, Italy, Egypt, Trinidad, with question from Australia, and from Curaçao, Netherlands West Indies.

In the upper part of the Pierre Shale this species occurs from 12 feet above the lower key bentonite to 156 feet below this level. 


\begin{tabular}{|c|c|c|c|}
\hline Locality & $\begin{array}{l}\text { Sample } \\
\mathbf{9 - \mathbf { R }}\end{array}$ & Locality & $\begin{array}{l}\text { Sample } \\
23-\mathbf{R}\end{array}$ \\
\hline & $11-\mathrm{X}$ & 36 & $1-\mathrm{X}$ \\
\hline & $12-X$ & & $2-S$ \\
\hline & 14-RR & & $3-S$ \\
\hline & $16-V R$ & & 4-VR \\
\hline & $18-\mathrm{R}$ & 37 & $3-\mathrm{VR}$ \\
\hline & $22-R$ & & 6-VR \\
\hline & $4-R$ & & $10-R$ \\
\hline & $5-\mathrm{S}$ & 41 & 1-RR \\
\hline & $6-\mathrm{S}$ & & $3-\mathrm{VR}$ \\
\hline & $13-\mathrm{S}$ & & $5-R$ \\
\hline & $15-X$ & $45 \ldots$ & $1-X$ \\
\hline
\end{tabular}

Genus OSANgularia Brotzen, 1940

Osangularia navarroana (Cushman)

Plate 10, figures 4a-c

Pulvinulinella navarroana Cushman, 1938, Cushman Lab. Foram. Research Contr., v. 14, pt. 3, p. 66, pl. 11, fig. 5.

Parrella navarroana (Cushman). Finlay, 1939, Roy. Soc. New Zealand, Trans. Proc., v. 68, p. 523. (invalid designationsee Thalmann and Graham, 1952, Cushman Found. Foram. Research Contr., v. 3, p. 31-32).

Osangularia navarroana (Cushman). Brotzen, 1960, Sveriges Geol. undersökning Årsb. 34, no. 5, ser. C, no. 435 , p. 30, text fig. 8 , nos. $1 \mathrm{a}-\mathrm{c}$.

Test trochoid, composed of $21 / 2$ to 3 whorls in larger specimens, biconvex, umbilical side slightly more convex, axial periphery acute, equatorial periphery smooth, slightly lobulate in some specimens, with a distinct but narrow flangelike keel; chambers fairly distinct, about 10 in the final whorl, of uniform shape, in crease regularly and gradually in size as added, not inflated; sutures strongly limbate on both sides, generally flush with the surface but may be slightly raised or depressed, radial to slightly curved on umbilical side, not sigmoid, end in a large mass of cloudy shell material at the center of the coil, oblique on spiral side, straight to slightly curved; wall surface slightly roughened but not granular, perforations distinct but fine; aperture on umbilical side, a distinct, slightly protruding, narrow slit on the apertural face about one-fourth the chamber height from the periphery, directed at a high but variable angle to the periphery, extends nearly to the base of the apertural face; a very small interiormarginal slit set in a fairly deep invagination near the center of the base of the final chamber is also present. Dimensions of a verage-sized specimens: maximum diameter, 0.25 to $0.3 \mathrm{~mm}$; minimum diameter, about $0.25 \mathrm{~mm}$; thickness, 0.1 to $0.15 \mathrm{~mm}$.

Remarks.-The Pierre specimens differ from the type description of Osangularia navarroana in lacking the slightly granular surface and slightly sigmoid sutures on the umbilical side and in not having the aperture in the plane of coiling. The type specimens of this species were examined and were found to be imperfectly preserved. Their surfaces do appear granular, but this is apparently due to preservation rather than original texture. In addition, the apertural characters of the types are obscure. Better preserved specimens of this species from the U.S. National Museum collections exhibit apertures and wall texture exactly like these characters on the Pierre specimens.

Occurrence.-In the United States this species has been reported only from beds of Navarro ag? in the Gulf Coast Cretaceous deposits (Cushman, 1946, p. 144). It has also been reported from the Upper Cretaceous of the U.S.S.R.

This species occurs from 17 feet above tro upper key bentonite to 25 feet below the lower key bentonite in the upper part of the Pierre Shale.

Material. -400 to 550 specimens were fornd.

\begin{tabular}{|c|c|c|c|}
\hline Locality & Sample & Locality & Sample \\
\hline 5 & $4-X$ & $27 \ldots \ldots$ & $7-V R$ \\
\hline $7 \ldots \ldots$ & $15-V R$ & $42 \ldots \ldots$ & 8-R \\
\hline & 23-RR & $44 \ldots$ & $1 \mathrm{~A}-\mathrm{S}$ \\
\hline 11 & 3-VR & 45 & $1-C$ \\
\hline 27 & $\begin{array}{l}1-V R \\
6-R\end{array}$ & & $3-\mathbf{R}$ \\
\hline
\end{tabular}

Genus QUADRIMORPHINA Finlay, emend. Troalson, 1954

Quadrimorphina allomorphinoides (Reu's)

Plate 10, figures $5 a-c$

Valvulina allomorphinoides Reusis, 1860, Akad. Wiss. Wien, Math.-naturw. Kl., Sitzungsber., v. 40, p. 223, pl. 11, fig. 6. Discorbina allomorphinoides (Reuss). Franke, 1925, Greifswald Univ. Geol.-Paleont. Inst. Abh., v. 6, p. 91, pl. 8, fig. 11.

Discorbis allomorphinoides (Reuss). Cushman, 1\%26, Am. Assoc. Petroleum Geologists Bull., v. 10, no. 6, p. 606, pl. 20, figs. 18,$19 ;$ pl. 21 , fig. 5 .

Valvulineria allomorphinoides (Reuss). Cushman, 1931, Cushman Lab. Foram. Research Contr., v. 7, pt. 2, p. 43, pl. 6 , fig. 2 .

Quadrimorphina allomorphinoides (Reuss). Finlay, 1939, Royal Soc. New Zealand Trans. Proc., v. 69, pt. 3, p. 325.

Test trochoid, biconvex, with a low spire, umbilicus a shallow open inconspicuous depression in part overlapped by the apertural lip, axial periphary rounded, equatorial periphery roughly egg shaped in outline, lobate; chambers quadriserially arranged, enlarge rapidly as added, slightly inflated; sutures rather indistinct except in last whorl where they are slightly depressed and distinct, slightly curved and oblique on both sides, spiral suture indistinct for earlier whorls. distinct for last whorl; wall smooth, finely perforate, a few widely scattered moderately coarse perforations present; aperture a low-arched interiomarginal slit on the umbilical side, extends from near the periphery to the umbilicus, covered almost to the peripheral end of the aperture by 
the lip. Dimensions of average-sized specimens: maximum diameter, 0.15 to $0.2 \mathrm{~mm}$; minimum diameter, 0.1 to $0.15 \mathrm{~mm}$; thickness, 0.05 to $0.1 \mathrm{~mm}$.

Remarks.-The specimens resemble Allomorphina minuta Cushman in test shape and size and in having the overhanging umbilical lip. They differ in having the chamber's quadiserially, instead of triserially, arranged.

Troelsen (1954, p. 470), in his emendation of the genus Quadrimorphina, described the internal morphology of $Q$. allomorphinoides, the genoholotype of the genus Quadrimorphina. He discovered a low internal partition on the umbilical lip of the penultimate chamber and a thickening or crest which runs parallel to the aperture on the under side of the umbilical lip of the final chamber. Two of the Pierre specimens were dissected with acid, and both showed the crest beneath the final umbilical lip. This crest also joins the penultimate apertural lip in both. The junction is marked by a thickening of shell material which, as far as could be determined, attaches to the previous lip but does not extend to the chamber wall to divide the septal foramen. In Troelsen's specimens this thickening does extend to the chamber wall.

Test shape and chamber arrangement, and the presence of internal structures almost exactly as reported by Troelsen, leave no doubt that the Pierre specimens belong in $Q$. allomorphinoides.

Occurrence.-This species, under the generic names Valvulineria and Quadrimorphina, has been reported from beds of Austin, Taylor, and Navarro ages in the Gulf Coastal plain (Cushman, 1946, p. 138), from the Tpper Cretaceous of Maryland (Cushman, 1948a, p. 263) and California (Bandy, 1951, p. 503; Trujillo, 1960 , p. 330), and from the Upper Cretaceous and lower Tertiary of New Jersey (Olsson, 1960, p. 35). Elsewhere, it has been reported from the Upper Cretaceous of Austria, Poland, Bulgaria, France, Germany, the Neth. erlands, Sweden, Mexico, Colombia, Venezuela, Trinidad, Indonesia, and Australia.

In the upper part of the Pierre Shale this species occurs 66 to 126 feet below the lower key bentonite.

Material.-About 400 specimens were found.

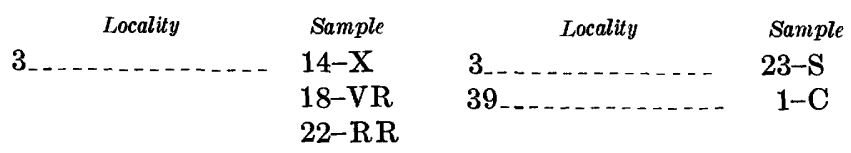

"Discorbis" quadrilobus Mello, n. sp.

Plate 1, figures 9a-c; plate 10, figures $6 a-c$

Test trochoid but with a very low spire so as to appear planispiral in edge view ; composed of about two whorls, inner edge of earlier whorl visible from spiral side, umbilical side completely involute, with a shallow, dimple-shaped umbilicus, equatorial periphery lobulate, axial periphery rounded; chambers distinct, inflated, four in the final whorl, increase rapidly in size as added; sutures depressed, radial on umbilical side, convex to. ward the apertural end on the spiral side; wall smooth. finely perforate; aperture a low interiomarginal $\mathrm{sli}^{+}$ extending from the periphery to the umbilicus. Dimensions of average-sized specimens: maximum diameter, 0.15 to $0.2 \mathrm{~mm}$; minimum diameter, 0.1 to $0.15 \mathrm{~mm}$; thickness, 0.05 to $0.1 \mathrm{~mm}$.

Remarks.- In his emendation of the genus Quadrimorphina, Troelsen (1954, p. 470) excluded from tha genus those forms that lack a prominent lip over the aperture. This structure is lacking in the new species. This species could be placed in Quadrimorphina a, originally defined by Finlay, but Troelsen's emendation and redescription of the genus are an improvement over the poor original description, and it seems better to place the new species in a temporary tentative generi? position than to resurrect the older and broader concept of Quadrimorphina.

Another species, apparently quite similar to "Discorbis" quadritobus n. sp., which must be removed from the genus Quadrimorphina as redefined by Troelsen, is $Q$. albertensis Mellon and Wall, 1956, from the lower part of the Fort St. John Group (early middle Albian) in northwestern Alberta, Canada.

Occurrence.-The species occurs 5 to 156 feet belor the lower key bentonite.

The type specimens of "Discorbis" quadrilobus are from locality 7 , sample 5 , and have been given the fo]lowing U.S. National Museum numbers: holotyp? 642665 , paratypes 642666 .

Material.-About 75 specimens were found.

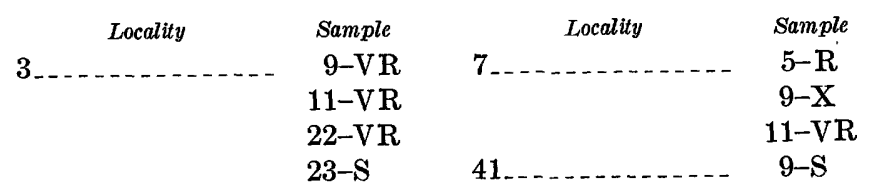

Family EPISTOMINIDAE?

Genus NUTTALIINELLA Belford, 1959?

Nuttallinella? disca Mello, n. sp.

Plate 2, figures 1a-c; plate 10, figures $7 a-c$

Test very low trochospiral, about equally biconvex; umbilical side completely involute, most specimens with small umbilicus filled with clear shell material; spircl side with all whorls visible; equatorial periphery nearly circular in outline, slightly to moderately lobulate, axicl periphery acute, with a slight margin of imperforate shell material; chambers usually about five in finsl whorl, slightly inflated, appear from the umbilical sice as gracefully curved triangles, from the spiral side appear as elongate, slightly overlapping rhombs except 
in the final whorl where the chambers are not overlapped and thus have smoothly curved peripheries; sutures distinct, on umbilical side nearly radial at umbilicus, gently convex distally as they approach the periphery, slightly limbate, on spiral side moderately oblique, gently curved, flush with the surface or slightly depressed between inflated chambers, occasionally slightly limbate, spiral suture distinct, slightly limbate, slightly raised in some specimens; wall smooth, glassy, with distinct perforations which are moderately coarse in proportion to test size; aperture interiomarginal, slitlike or slightly arched, extends from the umbilicus to the periphery, some specimens have a small to moderate sized lip extending over the aperture, this structure apparently lacking in other specimens. Dimensions of average-sized specimens: diameter, about $0.15 \mathrm{~mm}$; thickness, somewhat more than $0.05 \mathrm{~mm}$.

Remarks.-This species corresponds to the type description of the genus Nuttallinella (originally named Nuttallina by Belford $(1958$, p. 96$)$ and later changed to Nuttallinella (Belford, 1959) ) in test shape, chamber shape and arrangement, the nature and position of the aperture, the presence of the apertural lip (at least on some specimens), and the radial nature of the test wall. It differs in having a slight rather than a widely flaring margin of imperforate shell material, a character which is probably of specific rather than generic importance, in usually having a filled umbilicus, though in some specimens there is a shallow umbilical depression into which small triangular extensions of the chambers extend, and in apparently lacking a well-developed toothplate. Dissection of specimens of this species is difficult because of their extremely small size, but those that were dissected showed no internal toothplate of the size and shape described by Belford (1958, p. 97-98) for $N$. coronula (Belford), the type species of the genus Nuttallinella. The only internal structure observed was the apertural lip of the previous chamber, and this was present on only a few of the specimens dissected. Whether or not the toothplate described by Belford for $N$. coronula is contiguous with the apertural lip of that species or is an entirely separate structure may be of significance in determining whether or not the new species here described should be placed in the genus Nuttallinella.

Occurrence.-Specimens occur from 24 feet above the upper key bentonite to 156 feet below the lower key bentonite.

The holotype of Nuttallinella? disca is from locality 41 , sample 10, and has been given U.S. National Museum number 642667 . Unfigured paratypes and their U.S. National Museum slide numbers are as follows: from locality 41 , sample 10,642670 , from locality 41 , sample 9, 642669, and from locality 7, sample 1, 642668 . Material.-1,500 to 2,200 specimens were found.

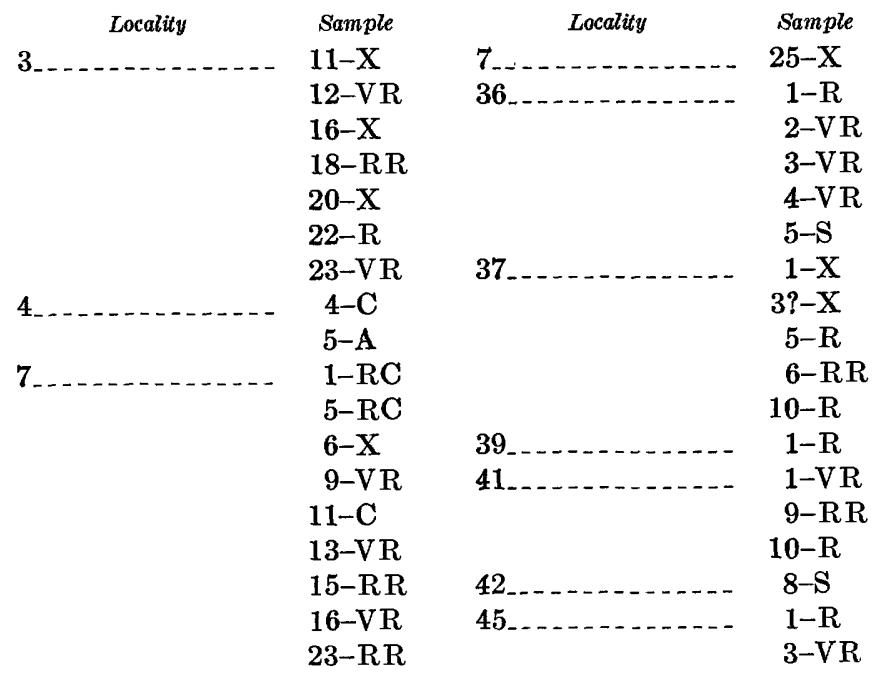

\section{Family CERATOBULIMINIDAE}

Genus HOEGIUNDINA Brotzen, 1948

Hoeglundina supracretacea (ten Dam)

Plate 11, figures 1a-c

Gyroidina caracolla Roemer, 1840-41, Versteinerungen norddeutschen Kreidegebirges, p. 97, pl. 15, fig. 22.

Epistomina caracolla (Roemer). Franke, 1925, Griefswald Univ. Geol.-Palaeont. Inst. Abh., v. 6, p. 88, pl. 8, fig. 10.

Epistomina supracretacea ten Dam, 1948, Inst. Français Pétrole Rev., v. 3, no. 6, p. 163, pl. 1, fig. 8.

Höglundina supracretacea (ten Dam). Bandy, 1951, Jour. Paleontology, v. 25, no. 4, p. 507, pl. 74, figs. 3a-c.

Test trochoid, biconvex, spiral side general ly less convex than umbilical side, completely involnte on umbilical side, umbilicus an inconspicuous shallow dimple; equatorial periphery smooth or very slightly indented at sutures of final chambers, axial periphery slightly keeled; chambers wedge shaped on umbilical side, rhomboid on spiral side, not inflated, increase gadually in size as added, six to eight in final whorl; sutures on umbilical side straight to slightly curved, strongly limbate, radial to slightly tangential, on spiral side gently curved, less strongly limbate, sutures of both sides typically flush with the surface but may be slightly raised or depressed; wall smooth, polished, finely perforate, mottled by irregularly distributed semitransparent and opaque areas; aperture on some specimens a low interiomarginal slit extending from the peripher: nearly to the umbilicus, on other specimens an approximately rectangular interiomarginal opening with the long axis of the rectangle parallel to the axis of coiling of the test and extending from close to the periphery toward the umbilical side for about one-quarter of th a chamber 
breadth, on a few specimens no aperture visible on the apertural face; all specimens have slotlike supplementary apertures which lie in the plane of coiling of the test, one on the umbilical side of each chamber just below the keel; these supplementary apertures may remain open in the final two or three chambers but are closed with secondary shell material in the earlier chambers of the final whorl. Dimensions of average-sized specimens: maximum diameter, 0.2 to $0.25 \mathrm{~mm}$; minimum diameter, about $0.2 \mathrm{~mm}$; thickness, about $0.1 \mathrm{~mm}$.

Remarks.-Disproportionate increase in the convexity of the umbilical side is characteristic of the largest specimens observed.

Complex toothplate structures seem to be present within at least the final chambers, but their detailed morphology was not investigated.

Occurrence.-Cushman (1946, p. 142) reported Hoeglundina supracretacea from beds of Navarro and Taylor ages in the Gulf Coast deposits as Epistomina caracolla. In Cretaceous deposits of the western interior, this species has been reported from the Pierre Shale of South Dakota (Applin, 1933, p. 219; Searight, 1938, p. 136), from the Pierre Shale of Nebraska, Kansas, and South Dakota (Loetterle, 1937, p. 62), from the Frontier Formation of Utah (Peterson, in Jones, 1953, p. 43), and from the Carlile Shale, Greenhorn Limestone, and Cody Shale of South Dakota and Wyoming (Fox, 1954, p. 101, 105). Other United States occurrences are from the Upper Cretaceous Red Bank Formation of New Jersey (Olsson, 1960, p. 37) and the Upper Cretaceous of California (Cushman and Church, 1929, p. 519 ; Trujillo, 1960, p. 338 ).

This species occurs from 32 feet above the upper key bentonite to 156 feet below the lower key bentonite in the upper part of the Pierre Shale.

Material. -700 to 850 specimens were found.

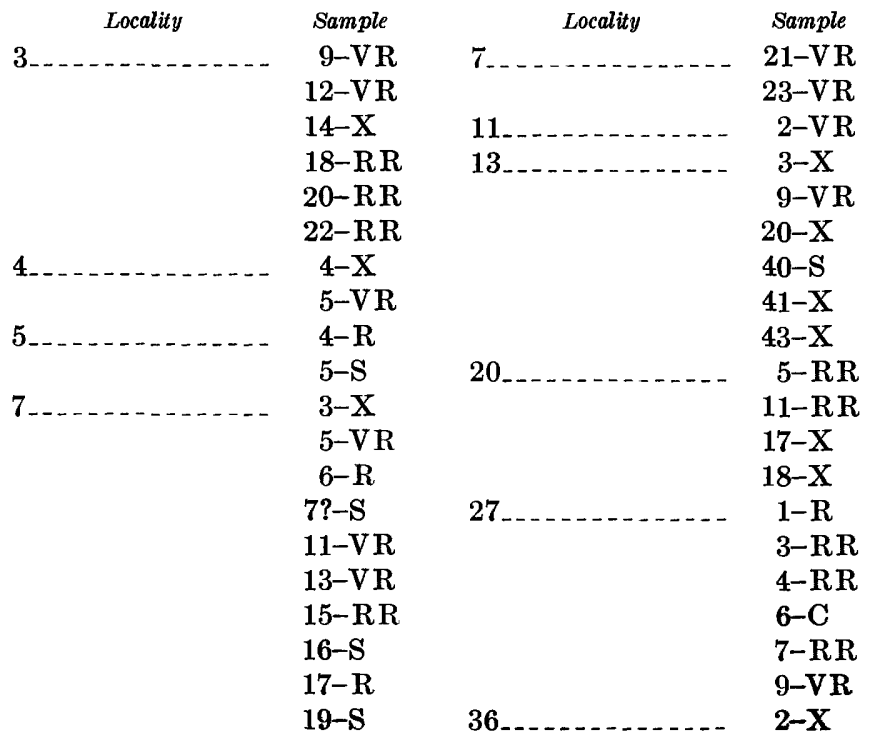

323-073 0-69-7

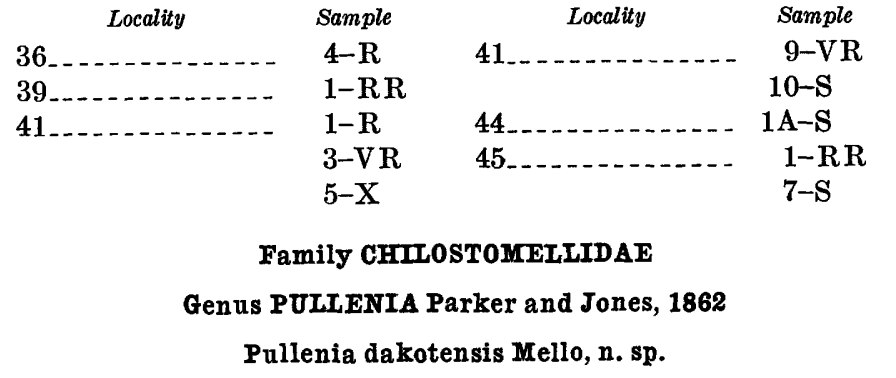

Plate 2, figures $2 a, b$; plate 11, figures $2 a, b$

Test planispiral, completely involute, moderately compressed, most specimens with small shallow umbilici, umbilical areas flush with the rest of the surface on some specimens, axial periphery rounded, equatorial periphery slightly lobulate, occasionally moderately lobulate; chambers fairly distinct, generally very slightly inflated, six to eight compose the final whorl, increase gradually and regularly in size as added; sutures fairly distinct, not limbate, range from radial to markedly convex toward the apertural faces of the chambers, slightly depressed between inflated chambers; wall smooth, with granular microstructure, finely perforate, with a dull gloss; aperture a uniformly narrow, arched, interiomarginal slit at the base of the last chamber, may be confined to the peripheral area or may extend nearly to the umbilici, not noticeably higher at the periphery, with a small overhanging lip, apertural face triangular, of varying shape, with well-rounded angles. Dimensions of average-sized specimens; maximum diameter, about $0.25 \mathrm{~mm}$; minimum diameter, about 0.2 $\mathrm{mm}$; thickness, 0.1 to $0.15 \mathrm{~mm}$.

Remarks.-A few of the smaller specimens are slightly asymetrically coiled. In some specimens the margins of the apertural face are elevated rather than rounded. These elevated margins are presumably the initial deposits for chambers that were never completed.

Cushman and Todd (1943) comprehensively discussed the genus Pullenia and its species. They utilized two ratios to help characterize the various species. These are: ratio $A$, ratio of length to width measured in apertural view, and ratio $B$, ratio of height of apertural face to height of last chamber measured in side view. Eleven of the Pierre specimens were measured, and these ratios calculated. Ratio A ranged from $2.4: 1$ to $1.9: 1$ and averaged $2.0: 1$; ratio $B$ ranged from $2.8: 1$ to $1.8: 1$ and averaged $2.3: 1$. Cushman and Todd listed the following species which have approximately these ratios:

\begin{tabular}{ccr}
\hline \multirow{2}{*}{ Species } & \multicolumn{2}{c}{ Ratio } \\
\cline { 2 - 3 } & \multicolumn{1}{c}{ A } & \multicolumn{1}{c}{ B } \\
\hline americana..... & $1.6: 1$ to $2.1: 1$ & $2: 1$ \\
multilobata..... & $2: 1$ & $2: 1$ \\
salisburyi....... & $1.65: 1$ & $2.3: 1$ \\
\hline
\end{tabular}


The new species differs from $P$. multilobata in having fewer chambers per whorl, a more rounded periphery, and smaller size; from $P$. salisbury $i$ in often having more than six chambers in the final whorl and in being much older ( $P$. salisburyi is reported from the Pliocene and Miocene) ; and from $P$. americana in lacking a considerably higher central part of the aperture and in having more chambers per whorl. Aside from the ratios, the number of chambers, degree of compression, and configuration of the periphery appear to set the Pierre specimens apart from any previously described species.

Other somewhat similar species are $P$. jarvisi, from which the Pierre specimens differ in lacking the deep umbilici and strongly convex apertural face, and $P$. elegans, which differs from the Pierre species in being about twice as large, in possessing a distinctly lobulate periphery, and in being much younger ( $P$. elegans is Recent in age).

Occurrence.-This species occurs from 81 feet above the upper key bentonite to 139 feet below the lower key bentonite. It is a persistent and common element in the fauna through this interval. The holotype and paratypes of Pullenia dakotensis are from locality 7 , sample 30 , and have been given the following U.S. National Museum numbers: holotype 642672 , paratypes 642673 . Another paratype, YPM 22933, was deposited in the Yale Peabody Museum.

Material.-1,500 to 2,500 specimens were found.

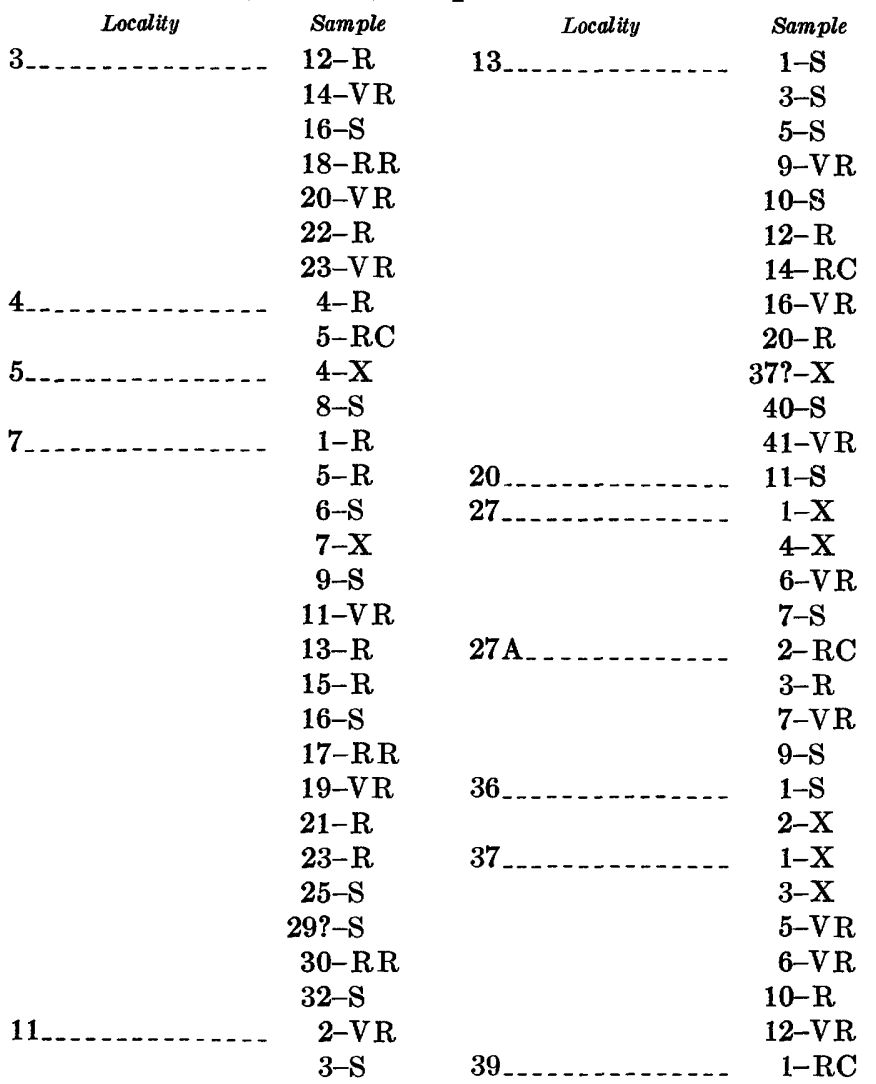

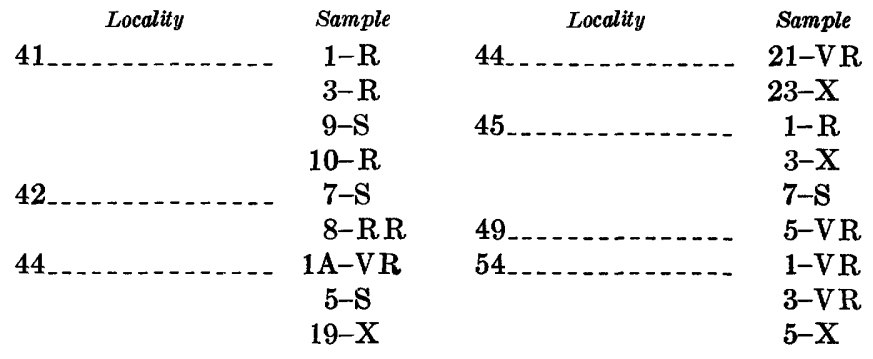

Family GLOBIGERINIDAE

Genus RUgoglobigeriNa Bronnimann, 1952

Rugoglobigerina ef. R. rugosa (Plummer)

Plate 2, figures 6a-c

Test trochoid, spire of moderate height. $2 \frac{1}{2}$ to 3 whorls compose larger specimens, umbilical side with a deep, wide, open umbilicus; chambers glok vlar, moderately appressed, generally four to five in the last whorl, increase in size uniformly and fairly rapidly within each whorl but generally with a marked increase in size of the first chamber of each whorl compared with the last chamber of the prececing whorl, all chambers visible on spiral side, only t] last-formed whorl visible on umbilical side; wall finely perforate, covered with small, unalined or weakly alined papillae; sutures depressed, radial, not limbate; aperture a high-arched opening into the umbilicus from the interior face of the last-formed chamber, most specimens with a modest thickening of the apertural margin, some specimens with short apertural lips extending into the umbilicus, and a few specimens with welldeveloped tegillae completely spanning the umbilicus. The few specimens preserving tegillae exlibit infralaminal but no intralaminal openings. Dimensions of average-sized specimens: maximum diameter, about 0.3 $\mathrm{mm}$; minimum diameter, about $0.25 \mathrm{~mm}$; thickness, 0.2 to $0.25 \mathrm{~mm}$.

Remarks.-Plummer (1926, p. 38), in her type description of Rugoglobigerina rugosa, stated that the chambers " $* * *$ are ornamented by irregularly developed rugosities or even indistinct, discontinuous, and rugulose ridges that radiate backward over each chamber from a central point on its periphery." Nearly all the well-preserved Pierre specimens exhibit rugosities, but none develop rugulose ridges. Also, the rate of increase in chamber size is less, and the height of the spire is somewhat greater in the Pierre specimens. For these reasons, the Pierre specimens are not. definitely placed in the species rugosa, although in other respects they are closely comparable with this species. The largest Pierre specimens are smaller than most srecimens of R. rugosa, but this size differential exists fc " many of 
the Pierre species as compared with conspecific specimens from other places and is not considered to be of taxonomic significance.

Occurrence.-Rugoglobigerina migosa has been reported from beds of Navarro age in the Gulf Coast deposits (Plummer, 1926, p. 36, 38; Sandidge, 1932, p. 367 ), from the Upper. Cretaceous in the Georges Bank canyons (Cushman, 1936, p. 419), from the Upper Cretaceous of New Jersey (Olsson, 1960, p. 50) and Delaware (Jordan, 1962, p. 7), and from the Campanian of California (Graham and Clark, 1961, p. 111; Graham, 1962 , p. 108). This species has also been reported from the Upper Cretaceous of Denmark, the Netherlands, Switzerland, Trinidad, Venezuela, Cuba, Peru, Puerto Rico, Nigeria, Angola, Australia, and on mid-Pacific seamounts described by Hamilton (1953, p. 227).

In the upper part of the Pierre Shale the specimens here questionably referred to $R$. migosa occur from 6 feet above the lower key bentonite to 143 feet below this level, with a doubtful occurrence at the base of the Virgin Creek Member 197 feet below the lower key bentonite.

Material.-Several thousand specimens were found.

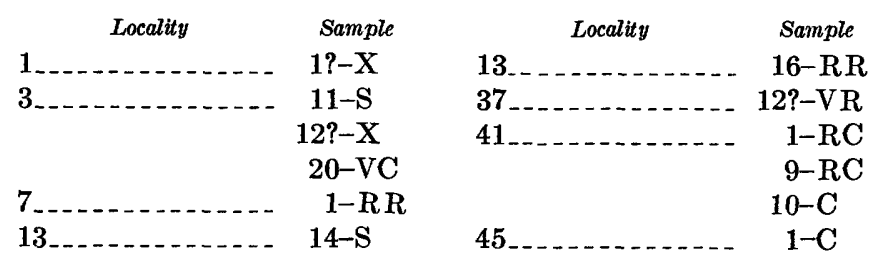

Genus BIGLOBIGERINELLA Laliker, 1948

Biglobigerinella biforaminata (Hofker)

Plate 2, figures $3 a, b ; 4 ; 5$

Globigerinella biforaminata Hofker, 1956, Natuurhistorisch Maandblad, v. 45, no. 5-6, p. 51-57, text figs. 1-24.

Globigerina biforaminata Hofker, 1956, Paläont. Zeitschr., v. 30, Sonderheft, p. 76, pl. 9, figs. 68a-c; pl. 10, figs. 71a-c.

Globigerinella aspera (Ehrenberg). Cushman, 1931, Tenn. Div. Geology Bull. 41, p. 59, pl. 11, fig. 5 .

Biglobigerinella biforaminata (Hofker). Olsson, 1960, Jour. Paleontology, v. 34, no. 1, p. 44, pl, 8, figs. 7,8 .

Test planispiral or very slightly trochospiral in initial whorl, later planispiral, biumbilicate, degree of involution variable, in general partially evolute in small specimens, becomes increasingly involute with growth until in large specimens little or none of the previous whorl is visible; chambers globular, not closely appressed, increase rather rapidly in size as added, especially in larger specimens, six to seven in the final volution; sutures deeply depressed, radial; wall calcareous, covered with minute papillae, finely perforate; aperture in small specimens a medium- to high-arched equa- torial interiomarginal opening; above the aperture is 8 . small thin forward-projecting lip which widens into delicate flanges along the lateral margins of the aperture, these continue back along the base of the chamber to the junction with the previous chambers and occasionally continue slightly further into the umbilicus; well-preserved specimens exhibit a series of slightly overlapping flanges along the umbilical margins of the final whorl; in later chambers of larger specimens there are two lateral apertures instead of a single peripheral aperture, in succeeding chambers these apertures become umbilical, and in the final part of the last whorl of some of the largest specimens two separate chambers occur, each with an umbilically directed aperture; this stage is followed by two lateral chambers each with an umbilical aperture; the number of chambers required to make this transition from a single peripheral aperture to a bichambered final form, and their shape and size, are quits variable from specimen to specimen. Dimensions of. average-size specimens: maximum diameter, about $0 . \tilde{\varepsilon}$ $\mathrm{mm}$; minimum diameter, 0.2 to $0.25 \mathrm{~mm}$; thickness, about $0.15 \mathrm{~mm}$.

Remarks.-Individual specimens with a peripheral aperture may be slightly larger than some specimens that have begun the transition to the double-chambered state, but the average size of the double-apertured and double-chambered forms is greater than the larges', single-apertured specimens. No specimen observed developed more than a single pair of separate chambers.

Placing this species into a genus is quite difficult because of the diversity of the various classifications which treat the group to which this species belongs. Lalicker (1948) erected the new genus Biglobigerinella, the description of which includes most of the characters exhibited by the Pierre specimens. The Pierre specimens differ from the generic description in having a conspicuous high-arched aperture, in being partially evolute, at least in smaller specimens, and in having an apertural lip. When it is considered that Lalicker's generic description was based solely on his knowledge of a single species (B. multispina Lalicker), the type specimens of which are not perfectly preserved, the assignment of the Pierre specimens to this genus in spite of the differences noted above is possible.

Bolli, Loeblich, and Tappan (1957, p. 25) revised the generic description of Biglobigerinella by stating that the test is planispiral, nearly or completely involute, with a tendency in some species for the chambers of the final whorl to flare out in a less involute coil with a flange extending back on each side toward the previous whorl and curving backward at the umbilical mar- 
FORAMINIFERA, STRATIGRAPHY, PIERRE SHALE, FOX HILLS SANDSTONE, S. DAK.

gin as in Globigerinelloides. This revision of Lalicker's type description is in accord with the morphology of the Pierre species in all but one respect. The Pierre species does not flare out in a less involute coil, although many specimens do have flanges which extend back to, and in some cases beyond, the umbilical margins of the chambers. Bolli, Loeblich, and Tappan (1957, p. 23) draw attention to similarities between their species $B$. barri and $G$. algeriana Cushman and ten Dam and suggest that if they are in fact species of the same genus, then Globigerinelloides would be a senior synonym for Biglobigerinella.

Banner and Blow (1959, p. 9) placed Biglobigerinella Lalicker in synonymy with Globigerinelloides Cushman and ten Dam, which they reduced to the rank of subgenus under the genus Planomalina Loeblich and Tappan.

The Pierre specimens seem to me to be well accommodated within the genus Biglobigerinella Lalicker, both as originally defined and as redefined by Bolli, Loeblich, and Tappan. The reality, in a genetic sense, of the genus Biglobigerinella and of the correctness of the classification of Bolli, Loeblich, and Tappan is seriously challenged by Hofker $(1960$, p. 317), who stated that forms referable to the genus Biglobigerinella as defined by Bolli, Loeblich, and Tappan have developed in three different genetic lineages at separate times.

Nothing of a factual nature can be added here with respect to the controversy over the reality and the taxonomy of the genus Biglobigerinella. For the present the generic concept of Biglobigerinella is useful, even if polyphyletic, in that it encompasses forms with obvious morphologic similarities. If future work establishes the polyphyletic nature of the genus, then more subtle morphologic distinctions will have to be used to place the species of Biglobigerinella in other genera.

Occurrence.-This species has been reported, as Globigerinella aspera, from beds of Navarro age in Tennessee (Cushman, 1931a, p. 12, 13). Olsson (1960, p. 44) reported it from beds of Maestrichtian age in New Jersey. It has been reported from beds of Maestrichtian age in Germany, the Netherlands, Denmark, and Poland and from the Campanian-Maestrichtian boundary in Belgium.

In the upper part of the Pierre Shale, Biglobigerinella biforaminata occurs from the base of the sampled section, 197 feet below the lower key bentonite, to 72 feet above the upper key bentonite: One poorly preserved specimen, which may belong in this species, came from 137 feet above the upper key bentonite.

Material.-1,500 to 2,500 specimens were found.

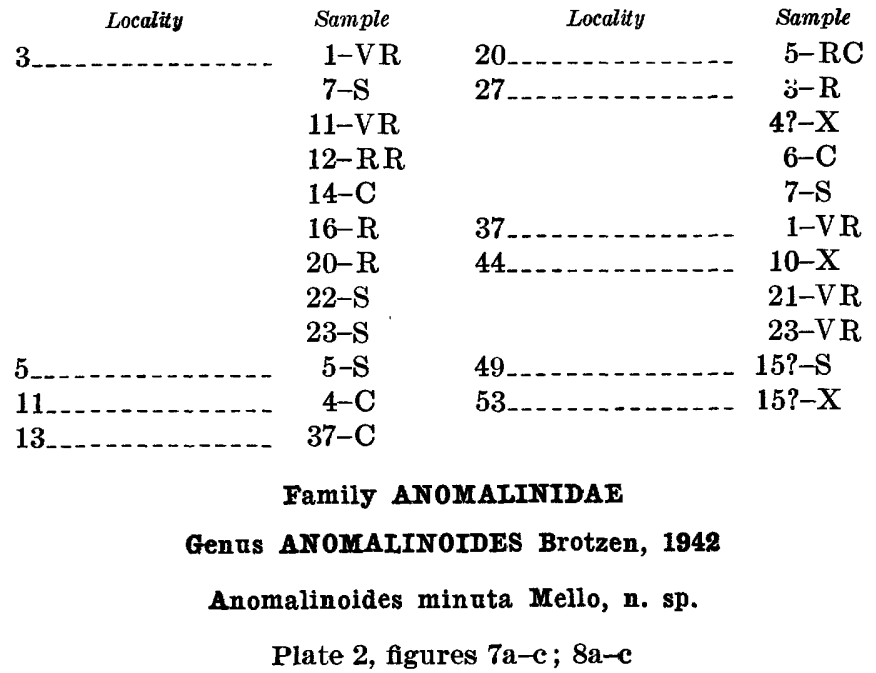

Test very small for the genus, nearly $\mathrm{f}^{\text {lanispiral, }}$ umbilical side involute, spiral side slightly evolute, moderately compressed, spiral side slightly convex, umbilical side slightly to moderately convex, axial periphery rounded, equatorial periphery smooth to slightly lobulate, only chambers of last-formed whorl visible on umbilical side, a small part of the previous whorl can be seen through a circular opening in the center of the spiral side, umbilical side with a narrow shallow umbilicus open in most specimens but in some specimens filled with a plug of shell material; chambers not inflated except slightly inflated in last part of final whorl of larger specimens, 7 to 10 in last-formed whorl; sutures distinct, flush, become slightly depressed between the last few chambers of larger specimens, slightly to moderately limbate, gently convex forward; we.1 smooth, moderately coarsely perforate; aperture a narrow interiomarginal slit extending from the umbilical side of the periphery to the spiral suture on the spir.1 side and thence beneath the last few chambers at their junctions with the spiral suture. Dimensions of average-sized specimens: maximum diameter, about $0.15 \mathrm{~mm}$; minimum diameter, 0.1 to $0.15 \mathrm{~mm}$; thickness, about $0.1 \mathrm{~mm}$.

Remarks.-The most striking attribute of this species is the very small size of the specimens. However, because the Pierre specimens of many other species are smaller than conspecific material from the Gulf Coast. and other areas, the importance of size as a diagnostic character is reduced. Of more diagnostic importance are the nearly planispiral nature of the test, the limbate sutures which are usually flush with the surface, the small umbilicus, and the small size of the opening on the spiral side exposing a part of the previous whorl.

The nature of the aperture, which extends beneath the last few chambers at their bases along the spiral suture, indicates that the species is to be placed ir Anomalinoides rather than in Anomalina. However, because of 
the small size of the specimens and the variable quality of preservation, the full development of the aperture was observed on only a few specimens.

Ocourrence.-The new species occurs from just above the upper key bentonite to 103 feet below the lower key bentonite.

The numbers for the holotype and paratypes of Anomatinoides minuta, and the samples from which they came, are given below-holotype : locality 3 , sample 18 , USNM 64278 ; figured paratype: locality 41 , sample 10, USNM 642681; unfigured paratypes: locality 3, sample 18, USNM 6 42679 ; unfigured paratypes: locality 41, sample 10, USNM 642680 and Yale Peabody Museum 22932.

Material. -50 to 100 specimens were found.

$\begin{array}{cccc}\text { Locality } & \text { Sample } & \text { Locality } & \text { Sample } \\ 3 \ldots & 18-\mathrm{R} & 7 \ldots \ldots \ldots & 11-\mathrm{S} \\ & 22-\mathrm{R} & 11 \ldots \ldots \ldots & 3-\mathrm{X} \\ & 23-\mathrm{S} & 13 \ldots \ldots \ldots & 1-\mathrm{R} \\ & 1-\mathrm{S} & 39 \ldots \ldots \ldots & 1-\mathrm{X}\end{array}$

Anomalinoides minuta Mello?

Plate 3, figures 2a-c

Remarks.-The specimens included here differ from typical Anomalinoides minuta in being noticeably more compressed and in having more incised sutures. In other respects they are very similar to $A$. minuta. Dimensions of average-sized specimens: maximum diameter, about $0.15 \mathrm{~mm}$; minimum diameter, about $0.11 \mathrm{~mm}$; thickness, about $0.04 \mathrm{~mm}$.

Occurrence.-Specimens occur 155 feet and 103 feet below the lower key bentonite, and a specimen doubtfully placed here came from immediately below the lower key bentonite.

Material.-Fewer than 40 specimens were found.

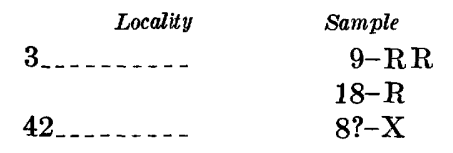

Genus PLaNulina d'Orbigny, 1826

Planulina sp.

Plate 11. figures $3 a-d$

Test much compressed, trochoid, evolute on both spiral and umbilical sides, axial periphery subacute; some specimens with a thick, fairly broad, imperforate keel, other specimens with an imperforate periphery but lacking the keel; equatorial periphery lobulate, spiral side planar to slightly concave, umbilical side slightly convex to nearly planar, in some larger specimens the central part of both sides marked by a slightly raised irregular mass of shell material created by the junction of the limbate sutures; umbilical side in mort small specimens has a knoblike protrusion of clear sh $€ l$ material at the center; chambers fairly distinct, cre:cent shaped, increase regularly and fairly gradually in size as added, 9 to 10 in last-formed whorl, final few chambers in larger specimens slightly inflated; suturas distinct, limbate; in those specimens with thickened peripheral keel the sutures are strongly raised ard thickened, in other specimens raised slightly if at all, a little depressed between the slightly inflated final chambers, convex toward the apertural faces of thin chambers on both sides; wall extremely rough and irregular because of abundant large perforations and intervening irregularly thickened wall; aperture a lowarched equatorial interiomarginal opening which extends as an interiomarginal slit on the spiral side b?neath the final one to five chambers. Dimensions of average-sized specimens: maximum diameter, about 0.4 $\mathrm{mm}$; minimum diameter, about $0.3 \mathrm{~mm}$; thickness, about $0.1 \mathrm{~mm}$.

Remarks.-Because of the nearly planispiral nature of coiling, it is very difficult to differentiate between spiral and umbilical sides of the test, especially in largar specimens. As a result, it is difficult to determine to which side the apertural extension is directed. Spirn.1 and umbilical sides are somewhat better differentiated on smaller specimens, and these have the apertural extensions on the spiral side.

Topotype specimens of Planulina ariminensis (d'O"bigny), the type species of the genus Planulina, were found to be quite similar in general morphology to the Pierre specimens except that the slitlike apertural extension in $P$. ariminensis is to the umbilical side. The Pierre specimens are quite similar to $P$. astoriensis Cushman, Stewart, and Stewart but differ in having much larger perforations and a more irregular wall surface between sutures. They differ from $P$. cocoaensis Cushman in being less thick through the umbilical rogion and in having a less acute periphery.

The Pierre specimens probably represent a new spacies, but the scarcity of specimens and the variability shown by those recovered prohibits assignment of a specific name.

Occurrence.-The species occurs from 17 feet above the upper key bentonite to 29 feet below the lower key bentonite.

Material.-About 15 specimens were found.

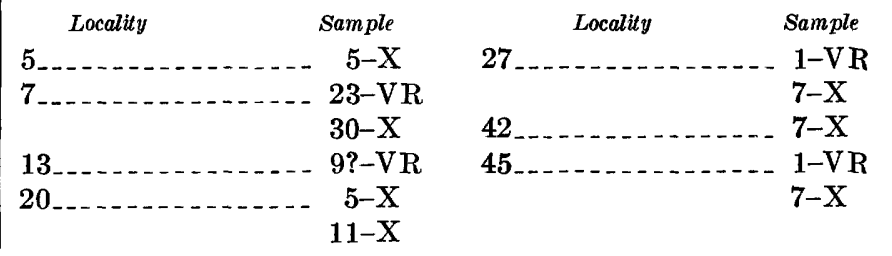




\section{Planulina kansasensis Morrow}

Plate 11, figures $4 \mathrm{a}-\mathrm{c}$

Planulina kansasensis Morrow, 1934, Jour. Paleontology, v. 8, no. 2 , p. 201, pl. 30 , figs. $2 \mathrm{a}, \mathrm{b}, 12 \mathrm{a}-\mathrm{c}$.

Planulina dakotensis Fox, 1954, U.S. Geol. Survey Prof. Paper 254-E, p. 119-120, pl. 26, figs. 19-21.

Test biconvex, trochoid, much compressed, slightly more convex on spiral side, with a moderately wide, shallow umbilical depression on umbilical side which is usually at least partly and sometimes entirely filled with clear shell material, composed of about $2 \frac{1}{2}$ whorls in large specimens, final whorl overlaps the previous whorl slightly on spiral side and extends from one-half to twothirds or even more over the previous whorl on the umbilical side, in larger specimens tends to become more evolute, axial periphery sharply rounded, not acute, equatorial periphery slightly lobulate; chambers distinct, eight to 10 in final whorl, increase gradually in size as added, of uniform shape except the last few in the final whorl of large specimens typically slightly inflated; sutures flush with the surface and slightly limbate except depressed and apparently not limbate between inflated chambers, slightly convex toward the apertural faces of the chambers on spiral side, straight to slightly convex on umbilical side; wall smooth, perforated by abundant, moderate-sized pores; aperture a narrow interiomarginal slit which extends from the periphery to the umbilicus, bordered above by a slight thickening of shell material which in most specimens develops into a modest flap at the umbilical end of the aperture and which extends over part of the previous whorl; in some specimens the umbilical flaps are fused into a thickened rim of shell material which borders the umbilicus. Dimensions of average-sized specimens: maximum diameter, about $0.25 \mathrm{~mm}$; minimum diameter, about $0.2 \mathrm{~mm}$; thickness, 0.05 to $0.15 \mathrm{~mm}$.

Remarks.-The holotype of Planulina kansasensis Morrow, the only type specimen available for comparison, is somewhat distorted and apparently silicified. It is about twice the size of even the largest Pierre specimens assigned to this species. The holotype also reveals more of the penultimate whorl on the umbilical side than do most of the Pierre specimens, but this seems to be a function of the stage of growth of the specimen because the penultimate whorl overlaps considerably more of its preceding whorl than it is itself overlapped by the final whorl. In most other respects agreement between the Pierre specimens and the holotype is good, except that the fine details of the apertural structures around the umbilicus are not present in the holotype, probably because of lack of preservation. All other specimens of $\boldsymbol{P}$. kansasensis in the U.S. National Museum collections were also compared with the Pierre specimens. None were as well preserved as, and most were larger than, the Pierre specimens, but in other respects agreement was good. One probable result of the quality of preservation is the presence of a larger umbilical extension of the apertural lip in most of the Pierre specimens as compared to most of the specimens with which they were compared.

According to Fox $(1954$, p. 120), P. dakotensis Fox differs from $P$. kansasensis in being smaller, in having fewer chambers, and in lacking a calcareous doposit over the central area on both sides. In the large suite of Pierre specimens are specimens that correspond exactly in size and most other particulars to the type specimens of $P$. dakotensis and that, by means of a gradational sequence of specimens, are associated with and grade up to larger specimens morphologically indistinguishable from the holotype and other specimens of $P$. kansasensis except with respect to size. Fox listed the number of chambers in the final whorl of $P$. dakotensis as seven to nine, whereas in the Pierre specimens this figure is sometimes eight but usually nine or 10. The calcareors deposits cited by Fox are present on some of the Pierre specimens and absent on others. Thus this character appears to be of no use in distinguishing these two species. The similarities between the type specimens of $P$. dakotensis Fox, the holotype, and other available specimens of $P$. kansasensis, especially when the transitional nature of the abundant and excellently preserved Pjerre specimens is taken into account, indicate that $P$. dakotensis. should be considered a junior synonym of $P$. kansasensis.

Occurrence.-Planulina kansasensis was originally reported from the Niobrara Formation of Kansas (Morrow, 1934, p. 201) and has since been reported from that formation in South Dakota, Nelraska, and Kansas (Loetterle, 1937, p. 49), South Dakota (Bolin, 1952, p. 62), North Dakota (Grunseth, 1955, p. 122), and Wyoming (Shaw, 1953, p. 50). It has also been found in the Hilliard Shale of Wyoming (Gauger, in Jones, 1953, p. 62), in the Cody Shale and C-rlile Shale of South Dakota and Wyoming (Fox, 1954, p. 109, 110), and from the Upper Cretaceous of Minnesita (Bolin, 1956, p. 294). In the Gulf Coast deposits this species has been reported from beds of Austin ago in Texas and Arkansas (Cushman, 1946, p. 157), anc in Canada it has been reported from the Boyne Member of the Vermilion River Formation in Saskatchewan and Manitoba (Wickenden, 1945, p. 42). P. dakotensis Fox has been reported from the Greenhorn limestone of South Dakota (Fox, 1954, p. 119-120). 
In the upper part of the Pierre Shale, $P$. kansasensis occurs from immediately below the lower key bentonite to 182 feet above the upper key bentonite.

Material. $-4,000$ to 8,000 specimens were found.

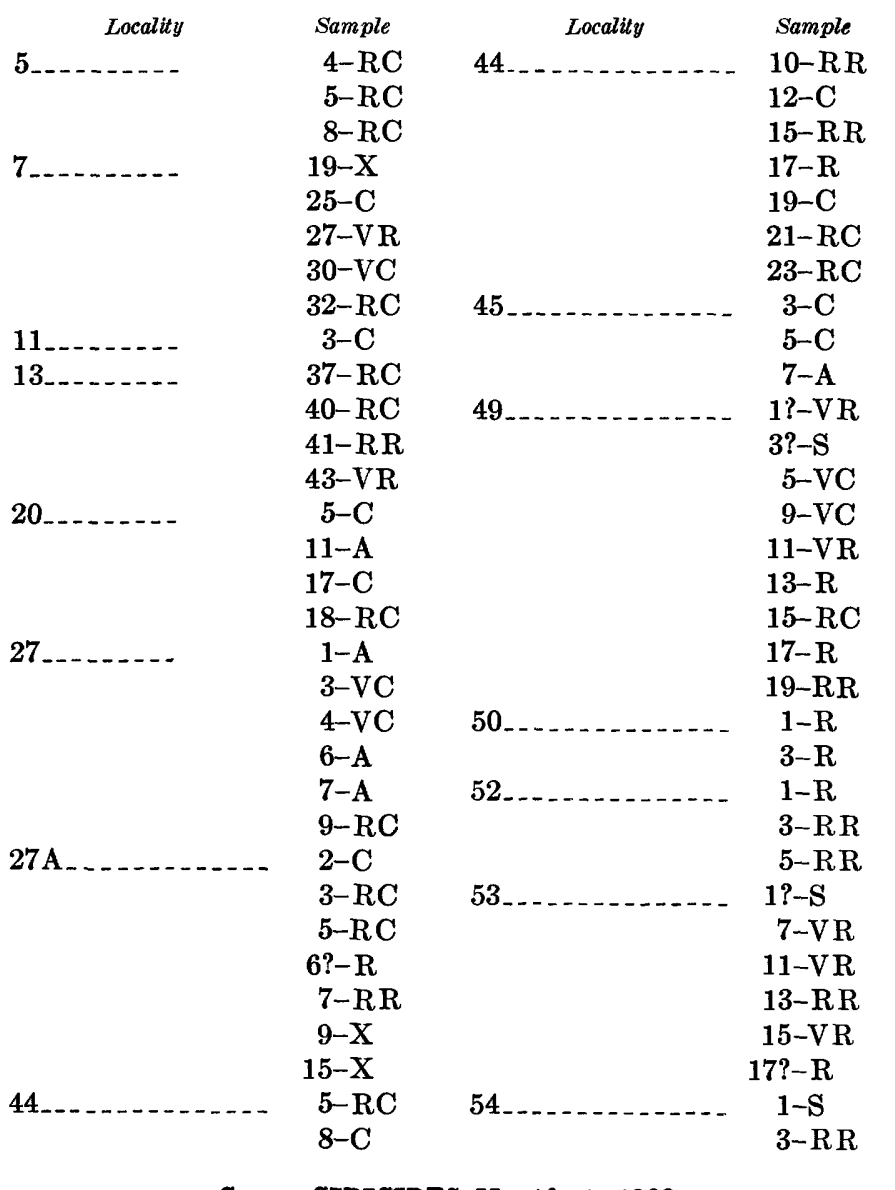

Genus CIBICIDES Montfort, 1808

Cibicides mobridgensis Mello, n. sp.

Plate 3, figures $3 a-c$; plate 11 , figures 5a-d

Test small for the genus, much compressed, trochoid, spiral side flat or very slightly convex, umbilical side moderately convex and completely or almost completely involute, axial periphery acute and becomes progressively thickened from the penultimate chamber to the earliest chamber of the final whorl, equatorial periphery smooth except slightly lobulate at the last few chambers, umbilicus small, filled with transparent shell material, all chambers visible on spiral side, generally only those of the last-formed whorl visible on umbilical side, but slightly evolute specimens have the inner edges of the chambers of the penultimate whorl visible beneath the umbilical filling, the degree of overlap of the chambers of the final whorl on the spiral side varies from almost none to about two-thirds the height of the previous whorl; chambers numerous, usually 11 in last-formed whorl, distinct, narrow, increase regularly and grad- ually in size as added; sutures distinct on spiral side, quite limbate, flush or slightly raised, eurved, oblique, on umbilical side flush or slightly depressed, radial at the umbilicus but become convex to the aperture toward the periphery, in some specimens final sutures sigmoid; wall smooth, performations rather course in proportion to test size; aperture a small, arched, interiomarginal opening at the periphery or just to the umbilical side of the periphery, with a slitlike interiomarginal extension at the base of the final chamber or final few chambers on the spiral side; arched part rimmed by a slight thickening of shell material; spiral side extension overhung by a short thin flap of shell material. Dimensions of average-sized specimens: maximum diameter, about 0.15 $\mathrm{mm}$; minimum diameter, 0.1 to $0.15 \mathrm{~mm}$; thicknesr about $0.05 \mathrm{~mm}$.

Remarks.-Planulina waltonensis Applin and Jordan differs importantly from the new species in being about three times larger, in lacking a peripheral thickening (keel), in having several more chambers in the final whorl, and in having raised sutures. $P$. texana Cushman also differs in being about three times larger and in lacking the peripheral thickening, as well as in othen respects. P. renzi Cushman and Stainforth differs in being much larger, in having raised sutures, and in having more chambers in the final whorl.

The new species is placed in the genus Cibicides on the basis of the generally planoconvex plan of the test. the involute nature of the umbilical side, the relativel 7 coarse perforations, and the extension of the apertur? onto the spiral side. Because of the very small size of the test, the apertural extensions are difficult to observe.

It is unlikely that the numerous specimens of thispecies are dwarfed or immature because they are associated with normal-sized specimens of other species. Also, no morphological gradation toward any othe* Pierre species was observed.

Occurrence.-This species occurs from 84 feet abov" the upper key bentonite to 70 feet below the lower key bentonite.

The holotype of Cibioides mobridgensis, USN"* 642285 , is from locality 37 , sample 1 . Unfigured para.types, USNM 642686 and Yale Peabody Museum 22934, are from locality 41 , sample 1 , as is the figured paratype, USNM 642687.

Material.-100 to 150 specimens were found.

\begin{tabular}{|c|c|c|c|}
\hline \multirow{4}{*}{$\begin{array}{c}\text { Locality } \\
7\end{array}$} & Sample & Locality & Sample \\
\hline & $\begin{array}{l}5-V R \\
6-V R\end{array}$ & $37 \ldots$ & $\begin{array}{l}1-R \\
3-X\end{array}$ \\
\hline & $7-X$ & 41... & $1-\mathrm{RC}$ \\
\hline & $9-X$ & & $3-\mathrm{VR}$ \\
\hline 31 & $3-X$ & & $5-V R$ \\
\hline $36 \ldots$ & $2-X$ & 44 & $5-\mathrm{S}$ \\
\hline
\end{tabular}


Cibicides harperi (Sandidge)

Plate 11, figures $6 a-c$

Anomatina harperi Sandidge, 1932, Am. Midland Naturalist, v. 13 , no. 5, p. 316 , pl. 29 , figs. $1,2$.

Cibicides harperi (Sandidge). Cushman, 1940, Cushman Lab. Foram. Research Contr., v. 16, p. 38, pl. 7, figs. 3-5.

Test trochospiral, composed of about two whorls, completely involute and moderately convex on umbilical side, partially evolute and slightly to moderately convex on spiral side, equatorial periphery smooth except slightly lobulate on last three or four chambers, axial periphery rounded and not keeled to rather acute and slightly thickened; chambers fairly distinct, closely appressed, very slightly if at all inflated, increase regularly and gradually in size as added, seven to 10 in the final whorl, the higher number more characteristic of larger specimens; sutures slightly to moderately limbate, flush with the surface or slightly depressed between somewhat inflated final chambers, sometimes secondarily thickened and raised in the early part of the final whorl, on umbilical side straight, radial, on spiral side oblique, straight to gently curved, spiral suture prominent, becomes progressively thicker away from the final few chambers and often terminates in a central knob of shell material; wall fairly thick, coarsely but not densely perforate, normal coarse perforations supplemented by scattered openings several times their size, often rough textured because of secondary deposits of shell material between pores; aperture a low interiomarginal slit extending from the umbilical side of the periphery to the basal margin of the final chamber on the spiral side and thence beneath the overhanging umbilical margin of the final chamber, a thin but distinct apertural lip present above that part of the aperture at the base of the apertural face. Dimensions of average-sized specimens: maximum diameter, about $0.3 \mathrm{~mm}$; minimum diameter, about $0.2 \mathrm{~mm}$; thickness, about $0.15 \mathrm{~mm}$.

Remarks.-The variation in the convexity of the spiral side is almost wholly due to the amount of secondary thickening along the spiral suture and in the center of the test. Thickness of the test is also variable, thicker specimens having more convex umbilical sides and thinner specimens having subacute and occasionally slightly thickened axial peripheries.

Occurrence.-Cushman has recorded cibicides harperi in beds of Navarro age in Alabama and Texas (1946, p. 159), in the Arkadelphia Marl of Navarro age in Arkansas $(1949$, p. 10). It has also been reported from the Red Bank and Navesink Formations of Maestrichtian age in New Jersey (Olsson, 1960, p. 52). This species has also been reported from the Upper Cretaceous of Venezuela.
$C$. harperi occurs in the upper part of the $\mathrm{F}$ :erre Shale from 42 feet above the upper key bentonite to the base of the sampled section, 197 feet below the lower key bentonite.

Material.-1,500 to 2,500 specimens were tc 1 und.

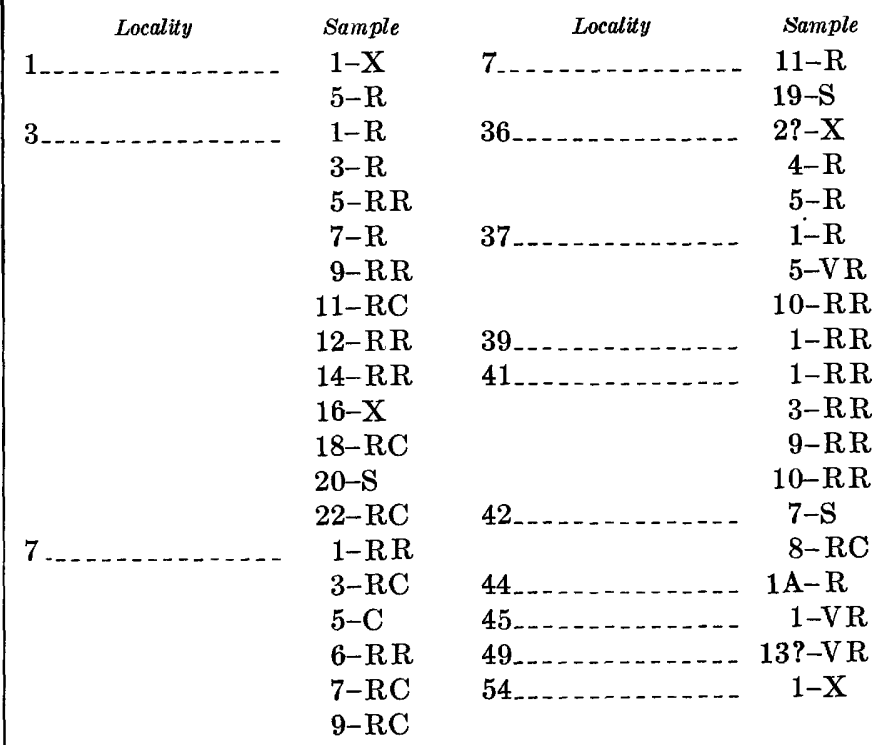

Cibicides subcarinatus Cushman and Deade-ick

Plate 3, figures 4a-c

Anomalina coonensis W. Berry (not Truncatulin", coonensis Berry ), 1929, in Berry and Kelley, U.S. Natl. Mus. Proc., v. 76, art. 19, p. 14, pl. 2, figs. 22-24.

Cibicides coonensis (Berry). Cushman, 1940, Cushman Lab. Foram. Research Contr., v. 16, p. 39, pl. 7, figs. 6-8.

Anomalina pseudopapillosa Carsey. Cushman (not Carsey), 1931, Tennessee Div. Geology Bull. 41, p. 61, pl. 12, fig. 4. Cibicides subcarinatus Cushman and Deaderick, 1944, Jour. Paleontology, v. 18, no. 4, p. 341.

Test trochoid, generally nearly equally biconvex, quite compressed, nearly completely involute on umbilical side, moderately evolute on spiral side, imperforate shell material often fills the central part of one or both sides of the test; equatorial periphery smooth, except slightly lobulate in final part of larger specirsens; axial periphery slightly thickened with imperforate shell material, subacute; chambers numerous, crescent shaped, closely appressed, not inflated, 10 to 12 in fir al whorl; sutures distinct, limbate, earlier ones often raised considerably, comma shaped, convex forward, raised sutures coalesce at their inner ends; wall coarsely perforate, quite thick, perforations often covered or filled in the early part of one or both sides, perforations generally coarser on spiral side; aperture an interiomarginal slit which extends from just to the spiral side of the periphery to the umbilical termination of the apertural face and thence along the umbilical margins of the final one to four chambers, umbilical part overhung 
by a short flap of shell material. Dimensions of averagesized specimens: maximum diameter, 0.25 to $0.3 \mathrm{~mm}$; minimum diameter, about $0.2 \mathrm{~mm}$; thickness, about $0.1 \mathrm{~mm}$.

Remarks.-The aperture is constant in extending to the more involute or umbilical side of the test. On some specimens the perforations seem to be coarser on the umbilical side. Also, the umbilical side often has more highly raised sutures and more pronounced fusion and thickening of the sutures than does the spiral side.

The species appears to vary more in test shape and ornamentation than most other species from the upper part of the Pierre Shale but can be fairly easily distinguished by its rather closely spaced crescent-shaped chambers, limbate sutures, coarse perforations, and apertural characters. The holotype of Cibicides coonensis Berry was the only type specimen of this species available for comparison, and it corresponds quite closely in every respect to a number of the Pierre specimens.

The nomenclatural confusion surrounding this species needs to be explained in some detail so that the designation given it here can be justified. The species Anomalina coonensis was erected by Berry (in Berry and Kelley, 1929, p. 14) and in the same publication (p. 12) he erected the species Truncatulina coonensis. The holotypes of both $A$. coonensis Berry and $T$. coonensis Berry, unfortunately the only specimens of either species available for study, are very probably members of separate and distinct species.

Cushman (1938b, p. 71) later erected a new name, $C$. berryi Cushman, for $T$. coonensis Berry. No reason was given for changing the specific name from coonensis to berryi, and in fact there was no valid reason for such a change. Because of the invalid nature of this name change, the specific name coonensis must be retained for this species upon its placement in the genus ribicides. This fact was pointed out by Cushman (1946, p. 160), and the name berryi was dropped therein in faror of the name coonensis.

The name $C$. subcarinatus was erected by Cushman and Deaderick (1944, p. 341-342) to substitute for the name $A$. coonensis Berry. This name change was also invalid at the time it was proposed because Cushman (1938b) had invalidly changed the name of T. coonensis Berry to C. berryi when he transferred that species to the genus Cibicides. Thus there was no species named $C$. coonensis which would have necessitated a specific name change for $A$. coonensis when Cushman and Deaderick determined that this species should be placed in the genus $C$ ibicides. The name $C$. subcarinatus was made a valid synonym for $A$. coonensis by Cushman's (1946, p. 160 ) abandoning the name $C$. berryi and subsitituting for it the valid name $C$. coonensis.

Occurrence.-Cushman (1946, p. 159) reported $C i b i$ cides subcarinatus from belds of Austin, Taylor, and Navarro ages in the Gulf Coast deposits, and it has been reported by Shaw (1953, p. 50) from the Niobrara Formation in Wyoming. It has also been reported from the Upper Cretaceous of Africa and, with question, Puerto Rico. Under the name $C$. coonensis, it has been reported from the Upper Cretaceous of California (Cushman and Goudkoff, 1944, p. 64) and Colombia.

C. subcarinatus occurs in the upper part of the Pierre Shale from 72 feet above the upper key bentonite to 139 feet below the lower key bentonite.

Material. - 800 to 1,500 specimens were found.

\begin{tabular}{|c|c|c|c|}
\hline Locality & Sample & Locality & Sample \\
\hline \multirow{7}{*}{3} & $12-\mathrm{S}$ & $7 \ldots \ldots$ & 13-RR \\
\hline & 14-RR & & $16-V R$ \\
\hline & $16-\mathrm{RC}$ & $36 \ldots$ & $1-\mathrm{VR}$ \\
\hline & $18-\mathrm{RC}$ & & $2-S$ \\
\hline & $20-\mathrm{RC}$ & & $3-V R$ \\
\hline & $22-\mathrm{RC}$ & & $5-\mathrm{S}$ \\
\hline & $23-X$ & $37 \ldots$ & $1 ?-\mathrm{VR}$ \\
\hline \multirow[t]{2}{*}{4} & 4-RC & & $3-\mathrm{VR}$ \\
\hline & $5-\mathrm{RC}$ & & $5-\mathrm{X}$ \\
\hline \multirow[t]{6}{*}{$7-\ldots$} & $3-R$ & & 10-RR \\
\hline & $5-\mathrm{RR}$ & $39 \ldots$ & 1-RC \\
\hline & $6-\mathrm{R}$ & $41 \ldots$ & $3-\mathrm{RC}$ \\
\hline & $7-\mathrm{RC}$ & & $5-\mathrm{R}$ \\
\hline & 9-RR & $54 \ldots \ldots$ & $7-X$ \\
\hline & $11-\mathrm{VR}$ & & \\
\hline
\end{tabular}

Incertae sedis sp. A

Plate 3, figures 1a-c

Test very small, single chambered, usually slightly to moderately broader than high, upper surface slightly convex, lower surface moderately convex to subconical, circular in apertural view; chamber wall finely and densely perforate and semitranslucent except for a transparent and much less densely perforate corona surrounding the aperture, corona covers about half the upper surface but is visible in only the best preserved specimens, surface smooth, polished in best preserved specimens; aperture a simple circular opening flush with and in the center of the slightly convex upper surface, without an internal tube. Dimensions of average-sized specimens: height, about $0.1 \mathrm{~mm}$; breadth, 0.1 to 0.15 $\mathrm{mm}$.

Remarks.-In a few of the Pierre specimens the upper or apertural surface is equally as convex as the lower surface so that the test is spherical.

These tiny enigmatic fossils are placed in the Order Foraminifera on the basis of their calcareous perforate wall, but I have found it impossible to place them in any previously named genus of Foraminifera. The flush, 
nonradiate aperture seems to exclude them from the genus Lagena Walker and Jacob, and the lack of an entosolenian tube excludes them from the genus Oolina d'Orbigny. The genus Orbulinaria Rhumbler, erected to contain a rounded or ellipsoidal, single-chambered calcareous-walled species, $O$. fallax Rhumbler, differs from the Pierre specimens in lacking a single well-defined aperture and in having a thicker wall. The Pierre specimens also differ from the genus Stomiosphaera Wanner in having considerably thinner walls.

This species is presented here as incertae sedis for the consideration of other workers on Foraminifera.

Occurrence.-This species occurs from 25 feet above the upper key bentonite to 82 feet below the lower key bentonite. Several specimens which may belong here came from 105 feet above the upper key bentonite.

Material. - 500 to 800 specimens were found.

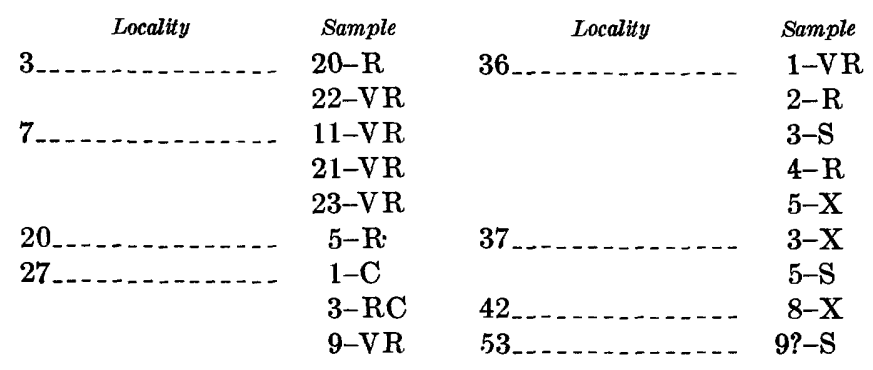

\section{DESCRIPTIONS OF MEASURED SECTIONS}

All sections from which samples have been examined for Foraminifera are described in the following pages to record accurately the stratigraphic positions from which the fossils came. The stratigraphically more significant sections examined are in this group, and although many other sections were measured, this group is considered sufficient to detail the stratigraphic succession in the upper part of the Pierre Shale and lower part of the Fox Hills Sandstone.

Many of the graphic sections (pl.12) are longer than the actual thicknesses represented, because all bentonites, concretion layers, and other distinctive layers less than 1 foot thick are conventionally represented as 1-foot-units. The actual thicknesses of the bentonites and their correct stratigraphic positions are given in the written descriptions which follow. The sample positions shown on the graphic sections are relative to the nearest underlying bentonite or concretion horizon to eliminate the lengthening effect of the out-of-scale bentonite and concretion symbols.

The subjectively evaluated intensity of reaction to 10 -percent hydrochloric acid is represented by vertical lines to the right of the graphic columns (pl. 12). One line indicates that the rock is slightly colcareousthat is, it produces bubbles slowly and sparingly. Two vertical lines indicate a moderately calcareous rockbubbles are produced faster and more abundantly than for slightly calcareous rock, but the acid drop retains its shape and is slowly absorbed. Three lines indicate quite calcareous rock-bubbles are produced very fast, and their escape makes the acid drop "bcil" as it is quickly consumed. Four lines indicate very calcareous rock-acid dropped on this rock causes an almost explosive reaction in which large and small bubbles are produced as the acid is almost instantly consumed.

Units divide the stratigraphic columns and are based on readily recognizable changes in the shale, such as changes from calcareous to noncalcareous rock, from markedly silty shale to less silty or nonsilty shale, and from unstained or lightly stained shale to heavily stained shale. Generally, beds less than a foot or two thick are not separated as distinct units. Covered intervals have been indicated as separate units.

The terms "flaky," "chippy," "chunky," and "blocky" refer to the size and shape of pieces of shale exposed at or near the surface of the outcrop. These characters must be applied with considerable caution in diagnosing particular units at places other than at the sections described. It has been observed that, under different degrees of moisture content, soil cover, and steepness of slope, the same shale will often show diferent characteristics with respect to shape and size of weathered pieces. If the rock is composed of very thin platelets of shale, it is termed flaky; if it is composed of flat pieces $1 / 8$ - to $1 / 2$-inch thick, it is termed chippy; if it is composed of more or less equant pieces from sbout $1 / 2$ - to 3-inches long, it is termed chunky; and if it is composed of larger regular or irregular pieces, it is termed blocky.

The graphic representations of the follcwing measured sections are on plate 12 .

\section{LOCALITY 1}

Section measured on a low east-facing cutbank along Virgin Creek, about 2 miles south of Promise, in SW1/4SW14 sec. 12, T. $16 \mathrm{~N}$., R. 29 E., Dewey County, S. Dak.

Pierre Shale:

Virgin Creek Member: Upper part:

2. Shale, dark-gray, noncalcareous, chippy; melanterite (?) stained on parting surfaces but lacks rusty and purple stain of underlying shale; weathers to smooth brownishgray slope covered to depth of about 5 in. with soil and light-gray shale chips. Top of unit is boulder-strewn flat at top of stream cut; lower contact is gradational with underlying shale.......................... 
Pierre Shale-Continued

Virgin Creek Member-Continued

Lower part:

1. Shale; dark somber gray when moist, light gray when dry; noncalcareous, brittle; flaky rather than clayey texture when given the mouth test; purple and rust stained on parting surfaces; fissile when weathered, forms buttresses. Slope is steep and thinly covered with small light-gray brittle chips harsh to touch. Melanterite(?) on parting surfaces and in shale first appears at about $20 \mathrm{ft}$ and becomes pronounced above $34 \mathrm{ft}$. Shale at $28 \mathrm{ft} 9 \mathrm{in}$. slightly calcareous.

Tan-weathering gray-cored limestone concretions occur at the base of the unit and and at $3 \mathrm{ft} 6$ in.

The following bentonites were observed: $3 / 4$ in. at $2 \mathrm{ft} 6$ in.; $1 / 2$ in. at $4 \mathrm{ft} 9$ in., yellow-green, very silty; $1 / 2$ in. at $5 \mathrm{ft} .0 \mathrm{in}$. (the bentonites at $4 \mathrm{ft} 9$ in. and $5 \mathrm{ft} 0$ in. represented by one bentonite symbol on graphic $\log$ ); 1 in. at $6 \mathrm{ft} 0$ in.; 1 in. at $9 \mathrm{ft} 3 \mathrm{in}$; $1 / 8 \mathrm{in}$. at $11 \mathrm{ft} 9 \mathrm{in}$.; $1 / 4 \mathrm{in}$. at $13 \mathrm{ft}$ 0 in.; $3 / 4$ in. at $27 \mathrm{ft} 9$ in.; $1 \frac{11}{2}$ in. at $32 \mathrm{ft}$ 3 in.; $1 / 2$ in. at $37 \mathrm{ft} 6$ in.

The base of the section is at the lower of two concretion layers in the bed of Virgin Creek about 2 miles south of Promise, S. Dak. This is about $1 / 2$ mile south of the site given by Searight $(1937$, p. 38$)$ as the base of the type section of the Virgin Creek Member. During fieldwork in 1960, I walked along the bed of Virgin Creek from about 11/4 miles to 2 miles south of Promise but found only a few feet of the Virgin Creek Member exposed in any one spot, until I came to the section described above. Consequently, it is considered likely but not certain that this section was measured at the type locality of the Virgin Creek Member. In any case, I have assumed that the lower concretion zone at this section is equivalent to that described by Searight as being at the base of the type section. The $1 \mathrm{ft}$ or so of shale observed beneath this zone, which supposedly is at the top of the Verendrye Member, is neither faunally nor lithologically distinet from the overlying shale.

\section{LOCALITY 3}

Section measured on a high, steep north-facing slope on the south bank of the Moreau River in $S W 1 / 4 S W 14$ sec. $5, T .15 N ., R$. $28 E$., Dewey County, S. Dak.

Pierre Shale:

Mobridge Member:

3. Shale, light- to medium-gray, typically calcareous, clayey-textured, blocky; contains
Pierre Shale-Continued

Mobridge Member-Continued

3. Shale-Continued

shell fragments throughout but in lower $25 \mathrm{ft}$ fragments of oysters and Baculites are more common. Small, scattered, punky, calcareous concretions 1 to 4 in. in largest dimension occur at $34 \mathrm{ft}$. Dense gray-cored limestone concretions overlie the $1 / 2-i n$. bentonite at $9 \mathrm{ft}$ in several places. The following bentonites were observed: $1 / 2$ in. at $9 \mathrm{ft} 0$ in.; $1 / 4$ in. at $20 \mathrm{ft} 6$ in.; 2 in. at $22 \mathrm{ft} 9$ in.; 1 in. at $27 \mathrm{ft} 0$ in.; 4 in. at $38 \mathrm{ft} 0$ in.; 1 in. at $41 \mathrm{ft} 6$ in.; 2 in. at $46 \mathrm{ft} 6 \mathrm{in}$.; $3 \frac{2}{2}$ in. at $51 \mathrm{ft} 3 \mathrm{in}$; 144 in. at $55 \mathrm{ft}$ 0 in.; 1 in. at $58 \mathrm{ft} 0$ in.; 2 in. at $60 \mathrm{ft} 10 \mathrm{in.;}$ and 3 in. at $75 \mathrm{ft} 0$ in.

The lower contact is gradational. The 3-in. bentonite at the top of the unit is overlain by about $1 \mathrm{ft}$ of heavily weathered shale to the top of the exposure.

Virgin Creek Member:

Upper part:

2. Shale; like unit 3 , includes shell fragments but is noncalcareous.

Lower part:

1. Shale, dark-gray, noncalcareous, flaky-textured; blocky when fresh, maroon and rust stained and chippy when weathered. Staining becomes less pronounced in upper $27 \mathrm{ft}$. Shell fragments present in upper $10 \mathrm{ft}$. A layer of flattened limestone concretions occurs $1 \mathrm{ft} 6$ in. above the base. At $4 \mathrm{ft} 9 \mathrm{in}$. is a layer of larger, flattened, noncalcareous concretions that are gray cored, red-weathering, 2 to $8 \mathrm{in}$. thick, and 2 to $4 \mathrm{ft}$ long. A less persistent layer of 1- to 8-in. thick, tan- to rust-weathering, gray-cored limestone concretions occurs at $42 \mathrm{ft} 6$ in. A few scattered concretions like those at $4 \mathrm{ft}$ $9 \mathrm{in}$. occur from $6 \mathrm{ft} 4$ in. to $10 \mathrm{ft} 10 \mathrm{in}$. above base. A few massive light-gray limestone concretions measuring as much as 3 $\mathrm{ft}$ thick and 4 to $5 \mathrm{ft}$ across occur just below the $3 / 4$-in. bentonite at $12 \mathrm{ft} 2$ in., but they do not form a laterally persistent zone. The following bentonites were observed: $1 / 2$ in. at $2 \mathrm{ft} 6$ in., gypsiferous; 1 in. at $6 \mathrm{ft} 3$ in., olive green, white weathering, slightly silty; $1 / 2$ in. at $10 \mathrm{ft} 10 \mathrm{in.;} 1 / 4 \mathrm{in}$. at $11 \mathrm{ft} 2 \mathrm{in.;}$ $1 / 2$ in. at $12 \mathrm{ft} 2$ in.; $1 / 4$ in. at $14 \mathrm{ft} 2 \mathrm{in.;}$ $1 / 2$ in. at $23 \mathrm{ft} .4 \mathrm{in}$.

The upper contact is gradational. The base of the unit is at the level of the Moreau River.

The lower part of unit 1 is correlated with the section at locality 1 on the basis of the numerous bentonite beds, similar lithology of the shale, and concretion layers. The shale below the lowest concretion layer, which is considered to mark the base of the Virgin Creek Member, is exactly like that above the concretions 


\section{LOCALITY 4}

Section measured on a high, north-facing slope on the south bank of the Moreau River in $W_{1 / 2}^{1 / 2} W_{14}^{1 / 4}$ sec. 20, T. 15 N., R. $27 \mathrm{E}$., Dewey County S. Dak.

Pierre Shale:

Mobridge Member:

5. Shale, chocolate-brown, calcareous, chunky, gray-weathering; becomes caramel brown and brown weathering above about $24 \mathrm{ft}$, probably because of oxidation. Thin veins of powdery gypsum(?) become common above $35 \mathrm{ft}$ or so. At $14 \mathrm{ft} 3$ in. is an ill-defined 1- to 2-in. layer of bentonitic shale overlain in several places by dense limestone concretions $1 \mathrm{ft}$ or so thick and about $2 \mathrm{ft}$ long. At $36 \mathrm{ft} 4 \mathrm{in}$. is a 1-in. layer of vertically fibrous calcite

4. Shale; like unit 5, except noncalcareous. At the base is a $1 / 2$-in. greenish-gray bentonite bed. At $6 \mathrm{ft} 3$ in. is a $2 \frac{1}{2}$-in. layer of graded greenishgray bentonite.

3. Shale, like unit 5 , differs from unit 4 only in being slightly calcareous. At the base of the unit is a 1- to 2-in. layer of heavily rust- and melanterite(?)-stained shale. At $6 \mathrm{ft} 3 \mathrm{in}$. is a $1 / 2$-in. thick reddish-yellow bentonite; a 5 -in. thick white-weathering and prominent, graded, gray to gray-green bentonite is at $8 \mathrm{ft} 3 \mathrm{in}$.; a 2-in. thick graded grayish-green bentonite is at $11 \mathrm{ft} 2$ in.; a $3 / 4$-in. thick orange-stained bentonite is at $12 \mathrm{ft} 8 \mathrm{in}$.; a 1-in. thick gray bentonite is at $16 \mathrm{ft} 2$ in. and a 2-in. thick gray bentonite is at $16 \mathrm{ft} 7 \mathrm{in}$. - the last two bentonites are represented by one symbol on the graphic $\log$

2. Shale; like unit 5, except noncalcareous. A fairly persistent layer of dense limestone concretions with yellow calcite crystals lining cracks is at the base, and a $1 / 2$-in. layer of waxy gray bentonite is at $4 \mathrm{ft} 6$ in

1. Shale; like unit 5 . At $8 \mathrm{ft} 0 \mathrm{in}$. is a 3 -in. layer of heavily melanterite(?)-stained shale. At $10 \mathrm{ft}$ 6 in. is a 2-in. layer of light-gray very silty bentonite, and a similar 2-in. layer is at $20 \mathrm{ft}$ 8 in.

Base of the unit is about $20 \mathrm{ft}$ above the Moreau River.

\section{LOCALITY 5}

Section measured on a moderately steeply sloping west-facing exposure on the east bank of Whitehorse Creek in $S E_{1 / 4}^{1 / 1 W^{1 / 4}} \mathrm{sec}$. 25, T. 16 N., R. 26 E., Dewey County, S. Dak.

Pierre Shale:

Elk Butte Member:

4. Shale, dark-brownish-gray, typically noncalcareous, chippy to chunky; weathers to a thin grayish-brown soil containing numerous shale chips. Shale becomes moderately rust stained above about $18 \mathrm{ft}$. At $4 \mathrm{ft}$, layer of mediumgray very calcareous tough, splinteryweathering shale forms a steep rise and dark band across the outcrop between 14 and $18 \mathrm{ft}$.
Pierre Shale-Continued

Elk Butte Members-Continued

4. Shale-Continued

At $23 \mathrm{ft} 6 \mathrm{in}$. is a layer of punky whiteweathering discoidal, small ( $1 \frac{1}{2}$ in. thick) concretions, some gypsum coated and noncalcareous and others uncoated and very eqlcareous. At $30 \mathrm{ft}$ is a layer of discoidal, fairly large ( $3 \mathrm{in}$. by $1 \mathrm{ft}$ ) brick-red to very dark weathering concretions that are light gra,y cored and dense, and noncalcareous. Several more such concretions are scattered in the shale above this level but do not form parsistent horizons.

Mobridge Member:

3. Shale, dark-brownish-gray, calcareous; forms somewhat steeper slope than overlying urit. At 6 in. is a $1 / 4$-in. bentonite. At $5 \mathrm{ft} 3$ in. iv a 1-in. layer of graded betitonite which grades upward into $1 / 2$ in. of bentonitic shale, whick is in turn sharply overlain by a 1/2-in. layer of indurated vertically fibrous calcite..........-

2. Covered interval

1. Shale; like unit 3 . Upper $10 \mathrm{ft}$ of this unit noncalcareous but otherwise like unit 3 . The noncalcareous shale between $8 \mathrm{ft}$ and $13 \mathrm{ft}$ $3 \mathrm{in}$. is darker gray than the rest of the shale in the unit and in places is rust stained. At $13 \mathrm{ft} 3 \mathrm{in}$. is a $1 \frac{1}{2}$-in. band of heavily melanterite(?)-stained and gypsiferous bentonite. Ten inches above this bentonite is a 2 -ft bed of light-gray blocky very calcareous shale or marl. At $18 \mathrm{ft} 9 \mathrm{in}$. is a $1 / 4$-in. bed of melanterite(?)-stained bentonite. At $19 \mathrm{ft} 3$ in. is an 8 -in. bed of graded bentonite; the lovrer 2 to $3 \mathrm{in}$. is silty, biotitic, and gray and the upper part is waxy textured and olive green. This 8-in. bed is the upper key bentonite.

Base of this section is at the level of the bed of Whitehorse Creek

\section{LOCALITY 7}

Section measured on a steep, high extensive northwest-facing exposure on the southeast side of the Moreau River in NW1/4SW1/4 and $S W 1 / 4 N W 1 / 4$ sec. 11, T. 14 N., R. 25 E., Devey County, S. Dak.

Pierre Shale:

Mobridge Member:

9. Shale, medium-gray, calcareous, blocky; forms a nearly vertical face, becomes brownish gray and eventually brown in the upper $12 \mathrm{ft}$ as the top is approached, contains a number of thin brown beds of shale. In the upper $5 \mathrm{ft}$ are fve layers of flattened rusty to purple-weather:ng concretions about 1 to 4 in. thick and about 4 to 14 in. across. They are brick red inside and are moderately calcareous. The top of the exposure coincides with the top of this unit. -

8. Shale, medium-gray, noncalcareous, chippy, heavily rust- and melanterite(?)-stained; weathers to a deep brown. This unit is at about the level of the upper key bentonite in nearby sections
Ft. In.
0

6 
Pierre Shale-Continued

Mobridge Member-Continued

7. Shale; like unit 9, except medium gray throughout and contains numerous small fragments of pelecypod shells . . . . . . . . . . . . . . .

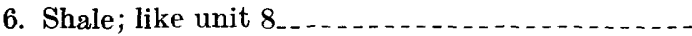

5. Shale; like unit 7, except lacks the shell fragments.

4. Shale, medium-gray, calcareous, chunky; unstained in lower $3 \mathrm{ft}$ but slightly rust stained in upper $5 \mathrm{ft}$. At $8 \mathrm{ft}$ is an 8- to 10-in. layer of very heavily melanterite(?)-stained noncalcareous shale like that in unit $8 \ldots . . . . .$.

3. Shale, medium-gray, chunky to blocky; has slight rust staining on parting surfaces in lower $21 \mathrm{ft}$, becomes more heavily rust stained and slightly melanterite(?) stained in upper $15 \mathrm{ft}$. A 2-in. layer of heavily melanterite(?)-stained noncalcareous shale is at the top of the unit, a similar layer 2 in. thick is at $7 \mathrm{ft} 3$ in., and a 3 -in. layer is at $10 \mathrm{ft}$. The bentonite at $14 \mathrm{ft} 9 \mathrm{in}$. is 8 to $10 \mathrm{in}$. thick and is the lower key bentonite. It is overlain by about $3 \mathrm{ft}$ of white-weathering hard, blocky, very calcareous shale or marl which grades into the overlying shale.......

2. Covered interval ...........................

1. Shale, medium-gray, calcareous, chippy to blocky; typically has some rust staining on fracture surfaces and occasionally with some melanterite(?) staining also, especially between 12 and $24 \mathrm{ft}$. Small gypsum-encrusted noncaleareous, indurated shale nodules from about 2 to 5 in. in diameter occur between 12 and $20 \mathrm{ft}$ but do not form persistent beds. The following bentonites were noted: 3 in. at $19 \mathrm{ft}$, silty, graded, rust and melanterite(?) stained; 1 in. at $21 \mathrm{ft} ; 3$ in. at $30 \mathrm{ft} 6$ in., slightly silty, waxy green; $1 / 2$ in. at $37 \mathrm{ft} ; 1 / 2$ in. at $44 \mathrm{ft}$, heavily rust and melanterite(?) stained.

Base of the section is about $4 \mathrm{ft}$ above the level of the Moreau River

\section{LOCALITY 11}

Section measured on a high, very steep northwest-facing slope on the southeast bank of the Moreau River in $S 1 / 2 N W 1 / 4$ sec. 16, T. 14 N., R. 24 E., Dewey County, S. Dak.

Pierre Shale:

Elk Butte Member:

5. Shale; olive brown, except brownish gray in lower $2 \mathrm{ft}$; noncalcareous, chunky, plastic, partially oxidized; contains powdery gypsum(?) crystals on bedding planes. A 1-in. bentonite is at $2 \mathrm{ft} 2$ in. A 2 -in. orangeweathering, brick-red bed that is slabby, slightly calcareous, indurated, and in places concretion forming is at $12 \mathrm{ft}$, and a similar but less continuous bed is at $13 \mathrm{ft} 8 \mathrm{in}$.

Unit is overlain by gravel and sand........

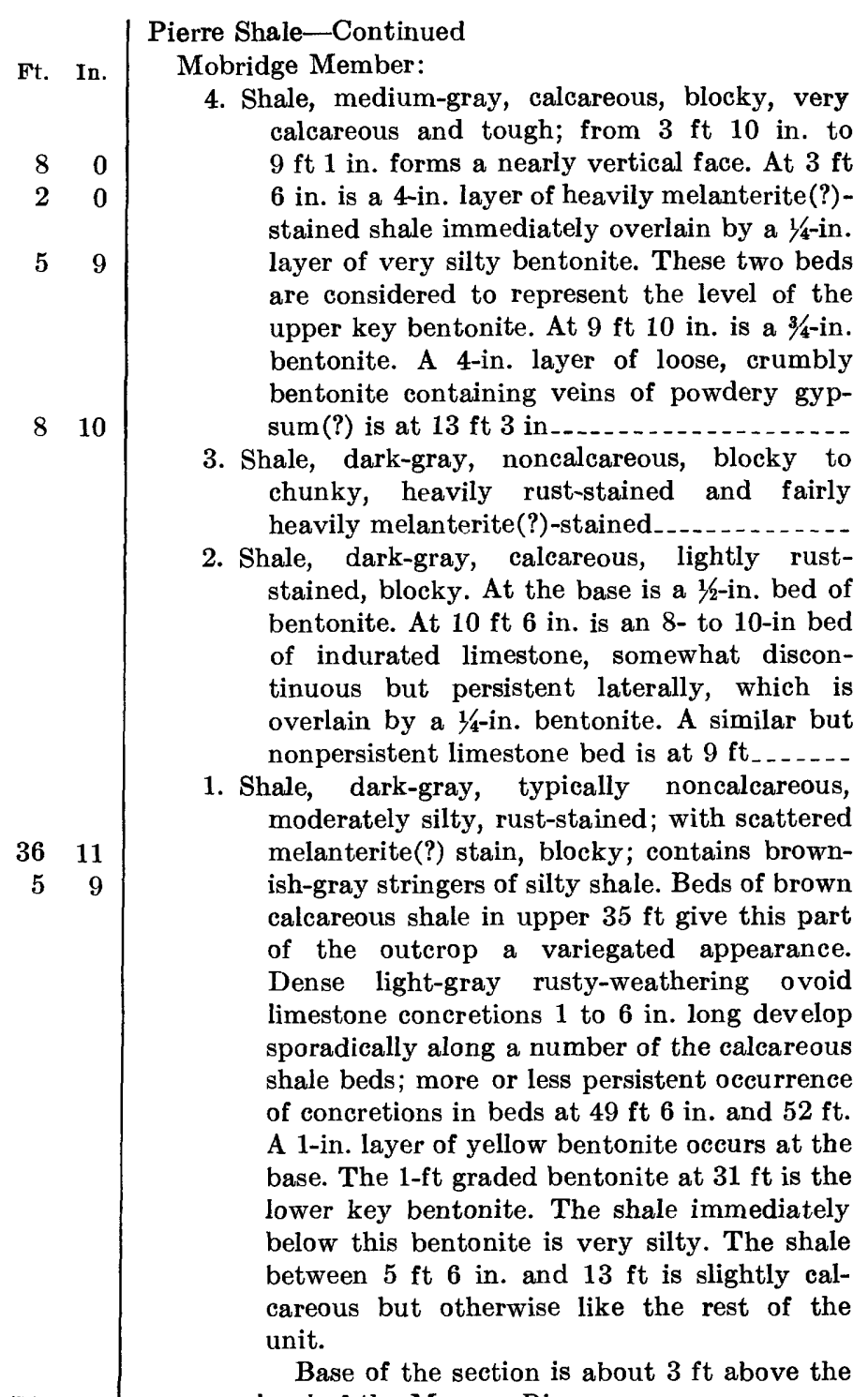
level of the Moreau River.................
Ft. In.

\section{LOCALITY 13}

Section measured on a southwest-facing slope on the northeast bank of the Moreau River in NE3/4SE $1 / 4$ sec. 6, T. $14 N ., R .24 E$., Dewey County, S. Dak.

Pierre Shale:

Ft. In.

Elk Butte Member:

6. Covered interval; slope weathers light gray and is littered with numerous pieces of reddishorange concretions. At top of this unit is a layer of rusty-weathering noncalcareous concretions 2 to 6 in. thick and 6 in. to $1 \mathrm{ft}$ long -

5. Shale, variegated; grayish-brown streaks and patches of shale contained in the predominant dark-gray shale; noncalcareous, chippy, weathers to tiny chips and flakes; weathered slope is brownish gray. At the base is a layer 
Pierre Shale-Continued

Elk Butte Member-Continued

5. Shale-Continued

of small ( 2 to 4 in. thick, 4 to 12 in. long) rusty-weathering olive-gray cored calcareous concretions. A similar concretion layer is at the top of the unit. ...................

Mobridge Member:

4. Shale, medium-gray to dark-gray, calcareous, blocky to chunky; weathers light gray; forms a somewhat steeper slope than units above and below. At $2 \mathrm{ft} 3 \mathrm{in}$. is a 1/2-in. bed of yellow bentonite. The upper key bentonite, $1 \mathrm{ft} 3 \mathrm{in}$. thick and graded, is at $12 \mathrm{ft} 6$ in. A 1 -in. bed of tan-green bentonite is at $17 \mathrm{ft} 6$ in. $A$ 3 -in. bed of heavily melanterite(?)- and ruststained shale containing numerous gypsum crystals is at $23 \mathrm{ft} 3 \mathrm{in}$. The shale in the lower 2 to $3 \mathrm{ft}$ is hard, blocky, and light gray -.

3. Shale, dark-gray, noncalcareous, blocky to crumbly, heavily rust- and melanterite(?)stained; contains scattered gypsum crystals and gypsum-encrusted nodules; weathers to a brownish-gray soil. Calcareous concretions, some of which are sparsely fossiliferous, occur in the basal $1 \mathrm{ft}$; shale for about the next $2 \mathrm{ft}$ above this bed is very silty, indurated, and veined with gypsum crystals.................

2. Shale, variegated; dark-gray and grayish-brown beds interlaminated, noncalcareous, chunky to crumbly; contains considerable silt and sand in stringers and on parting planes, considerable rust stain and some melanterite (?) stain in upper 15 to $20 \mathrm{ft}$. Weathers to a lightgrayish-brown soil. A 1- to 2-in. bed of darkgray limestone is at $35 \mathrm{ft}$. At the base is a 4 -in. light-brown bed composed of very thin intercalated layers of dark-gray shale and buff silt. The graded grayish-green lower key bentonite, $1 \mathrm{ft}$ thick, is at $16 \mathrm{ft} 8 \mathrm{in}$....-

1. Shale, dark-gray, calcareous, blocky to splintery ; contains considerable silt and sand on parting planes and as thin stringers. A 2-in. bed of bentonite is at $24 \mathrm{ft} 11 \mathrm{in}$. and a 1/2-in. bentonite is at $7 \mathrm{ft} 3$ in.

Base of the section is a few feet above the top of a slump block, about 20 feet above the Moreau River

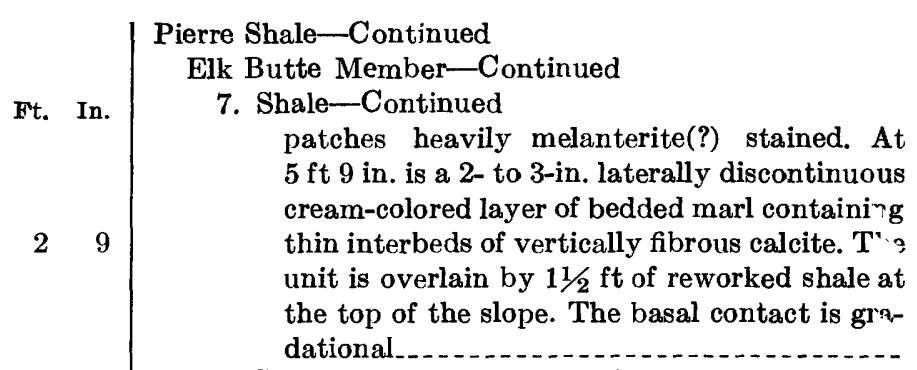

6. Shale, medium-gray, typically noncalcareous, chunky to chippy. Discoidal rusty-weathering grayish-tan-cored slightly calcareous to noncalcareous concretions 2 to 4 in. think and 8 in. to $1 \mathrm{ft}$ long occur in apparently laterally persistent layers at $8 \mathrm{ft} 3$ in., 10 ft 9 in., $12 \mathrm{ft} 6 \mathrm{in}$, and $17 \mathrm{ft} 6$ in. A few similar concretions are scattered between 8 and $18 \mathrm{ft}$. Scattered discoidal, white-weathering, grayish-tan-cored, quite calcareous ecncretions 1- to 3 -in. thick and 3 to 6 in. long occur between 17 and $24 \mathrm{ft}$. A 3- to 4-in. bad composed of $1 \frac{1 / 2}{\mathrm{in}}$. of yellow-green bentonite overlain by $1 \frac{1}{2}$ to $2 \frac{1}{2}$ in. of stringers of vertically fibrous calcite is at $33 \mathrm{ft}$. A few scattered shell fragments occur at about $29 \mathrm{ft}$

152 Mobridge Member:

5. Shale, medium-gray, calcareous, chunky to blocky; silt on bedding planes between 10 and $18 \mathrm{ft}$; contains scattered shell fragments in lower $20 \mathrm{ft}$. A $1 / 2$ - to $3 / 4$-in. yellow and white bentonite layer at the base. The upper key bentonite, a 1-ft bed, which is gray and sil' $\mathrm{y}$ in the lower 4 in. and which grades upward into olive-green bentonite and heavily calciteinterlaced bentonitic shale, is at $5 \mathrm{ft} 6$ in. A 1/8- to $1 / 4$-in. bentonite is at $16 \mathrm{ft} 6$ in., anc a $1 / 2-$ to $3 / 4-\mathrm{in}$. bentonite is at $26 \mathrm{ft} 3 \mathrm{in}$. A 2 -in. yellowish-olive-green bentonite, which is laterally incorporated into a 2- to 4-in. layer of cone-in-cone structure, is at $31 \mathrm{ft} 3 \mathrm{in}$., and a $1 / 2-$ to $1 \frac{1}{2}-\mathrm{in}$. bentonite is at $37 \mathrm{ft} 4 \mathrm{in} . \ldots . .$.

4. Shale; like unit 5 , except contains scattered patches of melanterite(?) stain ...........

3. Shale, medium-gray, calcareous, blocky, tough; forms a nearly vertical face; contains scattered shell fragments. Upper contact $\operatorname{grac}^{\prime} \mathrm{a}$ tional, lower contact sharp. . ............

2. Shale, dark-gray, noncalcareous, chippy, heavily melanterite(?)- and rust-stained; rather unlike the underlying shale and quite unlike the overlying shale. Lower contact gradational through about $1 \mathrm{ft}$

1. Shale, medium- to dark-gray, calcareous, chunky; has scattered but in places heavy rust and melanterite(?) stain. At $3 \mathrm{ft} 6 \mathrm{in}$. is a $1 \frac{1}{2}$ - to 3 -in. layer of gray graded bentonite overlain by about $1 \mathrm{ft}$ of blocky biotitic shale. The base of this unit is about $15 \mathrm{ft}$ above the Moreau River.
Ft. In. 


\section{LOCALITIES 27A AND 27}

Both sections measured on a high, steep, and extensive southwestfacing expo sure on the northeast bank of the Moreau River in $N E^{1 / 4}, N E^{1 / 4}$ sec. 11, T. 14 N., R. 2Q E., Dewey County, S. Dak. Section 27 measured on the upthrown side of a fault, and section 27A me asured about 50 feet further upstream on the downthrown block.

\section{LOCALITY 27A}

Fox Hills S andstone:

8. Shale, brownish-gray to grayish-brown, noncalcareous, chunky; some rust stain on fracture surfaces; typically contains little silt except in lower $6 \mathrm{ft}$ where more silt is present and color is browner. A fairly persistent layer of purple- to brick-red-weathering maroon-cored noncalcareous concretions 6 to $10 \mathrm{in}$. in diameter occurs at $11 \mathrm{ft} 6$ in., and a similar but less persistent layer occurs at $13 \mathrm{ft} 6$ in. A 2- to 3-in. laterally persistent indurated bed of rust-colored bedded shale is at $23 \mathrm{ft} 6 \mathrm{in}$. At the base of the unit is a 3/4-in. layer of very gypsiferous bentonite with a silty biotitic lower part. ...................

7. Shale, brownish-gray, noncalcareous, very silty, chunky; contacts with the less silty shale above and siltstone below are gradational...........

6. Siltstone, brownish-gray, clayey, mottled, chunky to crumbly; contains silt-filled borings. A 1/4-in. layer of gypsiferous and rust-stained bentonite (?) is at the base.

Pierre Shale:

Elk B utte Member:

5. Shale, typically grayish-brown in lower $17 \mathrm{ft}$, brownish-gray in upper part; noncalcareous, very silty, chunky; silt-filled burrows in upper 10 to $15 \mathrm{ft}$. At $6 \mathrm{ft} 3 \mathrm{in}$. is a discontinuous layer of limestone as much as $10 \mathrm{in.} \mathrm{thick}$ with layers of cone-in-cone structure above and below. At $8 \mathrm{ft} 6 \mathrm{in}$. is a prominent and laterally persistent layer of rounded 8 to 10 in. tan-weathering dense dark-gray limestone concretions with golden calcite fracture fillings. In places, as much as $10 \mathrm{in}$. of intercalated vertically fibrous calcite and cone-incone structure occupies this I evel. ...........

4. Shale, medium-dark-gray to brownish-gray, noncalcareous; becomes progressively siltier in upper $14 \mathrm{ft}$ before grading into silty shale of unit 5; hard and blocky when dry, chippy to chunky and more plastic when moist; molluscan shell fragments in lower 10 to $15 \mathrm{ft}$. A few scattered discoidal rusty-weathering brown-cored calcareous concretions in lower $3 \mathrm{ft}$. At $19 \mathrm{ft}$ are a $\mathrm{fe} w$ white-weathering rounded 4- to 8-in., dense gray-cored limestone concretions, the outer rinds of which are perforated by worm(?) tubes..........

3. Shale, brownish-gray, noncalcareous, chunky to blocky; heavily rust- and melanterite(?)stained in lower $4 \mathrm{ft}$, less heavily stained in upper $2 \mathrm{ft}$
Ft. In.
Pierre Shale-Continued

Elk Butte and Mobridge Members:

2. Shale, medium-dark-gray, typically noncalcareous, chunky; some rust stain on parting surfaces. The shale is very slightly calcareous in places. A few ovoid limestone concretions 1 to $3 \mathrm{ft}$ in diameter are at the base. At $4 \mathrm{ft}$ 6 in. is a 1-in. layer of heavily rust- and melanterite(?)-stained shale. At $12 \mathrm{ft} 3$ in. is a 6-in. to 1-ft layer of bedded marl and dense limestone which varies in thickness laterally. This indurated bed, which is taken as the base of the Elk Butte Member at Iocality 27, 50 yards away, is also considered to mark the base of the Elk Butte at this locality, despite the fact that the shale below it is noncalcareous. At $14 \mathrm{ft} 3 \mathrm{in}$. is a 2- to 4in. layer of melanterite(?)- and rust-stained shale. Between $16 \mathrm{ft}$ and $21 \mathrm{ft}$ are scattered rusty-weathering discoidal tan-cored concretions. Between $23 \mathrm{ft}$ and $25 \mathrm{ft}$ are a few scattered discoidal concretions, 1 to 4 in. in diameter, with tan calcareous rinds and dark pyritiferous limestone cores. A 3-in. indurated layer, composed of a basal 1/4-in. bed of bentonite, a middle $1 / 2$-in. bed of cone-in-cone structure, and an upper 2- to 21/2-in. layer of bedded marl and vertically fibrous calcite, occurs at $32 \mathrm{ft} 3 \mathrm{in}$. Between $48 \mathrm{ft} 9$ in. and $51 \mathrm{ft} 9$ in. are numerous white to tan-weathering gray-cored limestone concretions about 6 to 8 in. long and 2 to 3 in. thick ...... Mobridge Member:

1. Shale, medium-dark-gray, calcareous, chunky. The base of this section, which is on the downthrown block, is at the level of the upper key bentonite on the upthrown block........

\section{LOCALITY 27}

Pierre Shale:

Elk Butte Member:

5. Shale, dark-gray, noncalcareous, chippy, some rust and melanterite(?) stain on parting surfaces. At the base is a $1 / 2-$ to $1 \frac{1}{2}$-in. layer of cone-in-cone structure which overlies and nearly obliterates a thin bentonite layer......

Mobridge Member:

4. Shale, dark-gray, calcareous, chunky; scattered rust and melanterite(?) staining............

3. Shale; like unit 5 , except contains considerable silt. A 1-in. layer of heavily rust- and melanterite(?)-stained shale is at the top of the unit

2. Shale; like unit 4, scattered, 2- to 5-in. creamcolored punky very calcareous concretions and nonindurated lenses occur through this interval. A 1/2-in. layer of green bentonite, lightly interlaced with vertically fibrous calcite, occurs at 3 ft........

1. Shale, dark-gray, calcareous, chunky to blocky; crushed ammonite and pelecypod shells and shell fragments are present but scarce in the
F't. In.

Ft. In. 
Pierre Shale-Continued

Mobridge Member-Continued

1. Shale-Continued

lower $40 \mathrm{ft}$. At $17 \mathrm{ft} 6$ in. is a $1 / 8$-in. layer of rust-stained and gypsiferous bentonite. At 19 ft 9 in. is the 16-in. upper key bentonite. The bentonite is gray, very silty, and biotitic in the lower few inches and grades upward into blocky waxy light-green bentonite, which in turn grades upward into shale. This bentonite forms a conspicuous white-weathering band on the outcrop.

The base of the section is about $2 \mathrm{ft}$ above the level of the Moreau River...........

\section{LOCALITY 31}

Section measured on a high, steep west-facing exposure on the east bank of Pretty Creek in NE1/4SW1/4 sec. 12, T. 14 N., R. $21 E$, Ziebach County, S. Dak.

Fox Hills Sandstone:

4. Siltstone, grayish-brown, noncalcareous, sandy, clayey; contains scattered pods and lenses of melanterite(?); bedding planes typically disturbed, but where not disturbed thin (1/4 to 3 in.) interbeds of silty shale and very fine grained sand are often present. Thicker layers ( 1 to 5 ft) of noncalcareous shale and silty shale are also present in places. A few layers of heavily melanterite(?)-stained silty shale are present in the upper $25 \mathrm{ft}$. A few rusty-weathering browncored concretions occur at $7 \mathrm{ft} 3 \mathrm{in}$. A few tanto rusty-weathering dense blue-gray limestone concretions, usually heavily jacketed with conein-cone structure and 3 in. to $1 \mathrm{ft}$ thick, occur at $32 \mathrm{ft}$; a few similar concretions are also present at $42 \mathrm{ft}$, and several more are present at 62 and $64 \mathrm{ft}$. The slope continues upward, under heavy cover, for another 30 to $35 \mathrm{ft}$ above the top of unit 4. At top of slope are several scattered 2- to 4-ft thick concretions. These have calcareous rusty-weathering cores 6 in. to $2 \mathrm{ft}$ thick, a few of which contain fossils, and are jacketed by 1 to $2 \mathrm{ft}$ of calcareous indurated sand

Pierre Shale:

Elk Butte Member:

3. Shale, grayish-brown, silty, noncalcareous, typically lightly rust-stained; heavier concentrations of rust stain and some melanterite(?) stain at $5 \mathrm{ft} 5$ in. and $10 \mathrm{ft} 6$ in. A persistent layer of discoidal 2- to 4-in.-thick and 8- to 14-in.-long concretions at $11 \mathrm{ft} 6$ in. Concretions are rusty weathering, have an outer tan noncalcareous layer, and have a blue-gray calcareous core. At $13 \mathrm{ft} 6$ in. is a conspicuous 4- to 8-in. bed of cone-in-cone structure containing a few limestone concretions.....

2. Shale, olive-gray to grayish-brown, noncalcareous, heavily melanterite(?)- and ruststained. Beds of olive-gray shale weather with a violet patina. A fairly persistent layer of 8 - to 15 -in. thick rusty-weathering concretions is at $6 \mathrm{ft}$. Upper and lower contacts gradational
Ft. In.

Ft. In. 46

0

$74 \quad 0$
Pierre Shale-Continued

Elk Butte Member-Continued

1. Shale, brownish-gray, noncalcareous, chippy to chunky, moderately silty; occasional silt laminae. Weathered shale pieces deve'sp rusty or violet stain at about $5 \mathrm{ft}, 15 \mathrm{ft}$, and in upper $2 \mathrm{ft}$. Scattered rusty-weathering tan-cored septarian concretions occur above $11 \mathrm{ft} 6$ in. The rusty part is calcareous, but the tan part is not. Fractures are lined with gypsum crystals. A persistent layer of those concretions is at $25 \mathrm{ft}$. The base of the section is about $35 \mathrm{ft}$ above the creek bed.........

\section{LOCALITY 36}

The type section of the Mobridge Member, as defined by Searight (1937), consists of exposures in a series of small roadcuts along a segment of U.S. Route 12 (now abandoned) in sec. 17, T. 18 N., R. 30 E., Corson County, S. Dak. Most of these exposures were heavily covered when this study was made, and only isolated patches of rock could be seen. Consequently, no meaningful description or graphic log of this type section can be given. Five samples were taken from calcareous shale at this lecality, 75 to $98 \mathrm{ft}$ above the level where the road now ends and where it once abutted the now dismantled bridge over the Missouri River

\begin{tabular}{|c|c|c|c|}
\hline \multirow{2}{*}{ Locality 1} & \multirow{2}{*}{ Sample } & \multicolumn{2}{|c|}{ Position ab วve bridge level } \\
\hline & & Ft & In. \\
\hline $\begin{array}{l}28983 \\
28984 \\
28985 \\
28986\end{array}$ & $\begin{array}{l}1 \\
2 \\
3 \\
4 \\
5\end{array}$ & $\begin{array}{l}75 \\
80 \\
86 \\
92 \\
98\end{array}$ & $\begin{array}{l}0 \\
9 \\
6 \\
3 \\
0\end{array}$ \\
\hline
\end{tabular}

1 U.S. Geol. Survey Mesozoic collecting locality number.

\section{LOCALITY 37}

Section measured on the first two-level cut on the northeast side of the new roadbed for the Chicago, Milwaukee, St. Paul and Pacific Railroad, about 2 miles west along the track from the railroad bridge approaches, in sec. 13, T. 19 N., R. 29 E., Corson County, S. Dak.

Pierre Shale:

Mobridge Member:

Ft. In.

4. Shale, grayish-brown, noncalcareous, chippy. At $3 \mathrm{ft}$ is a layer of discoidal rusty- to purr'eweathering red-cored noncalcareous concretions 2 in. thick and 6 to 10 in. long. A few similar concretions are scattered below this concretion level. In the upper $9 \mathrm{ft}$ are scattered cream-colored calcareous nodules 1 to 3 in. thick. At the base of the unit is a 1/2-in. layer of heavily melanterite(?)-stained shale which immediately overlies a layer of concretions like that at $3 \mathrm{ft}$

3. Shale, medium-brown, gray-mottled, calcareous, plastic, partially oxidized. A persistent but somewhat discontinuous bed of indurated cream-colored marl 1 to 3 in. thick is at the base. A similar but more continous bed 4 to 6 in. thick is at $1 \mathrm{ft}$. $3 \mathrm{in}$. This thicker bed occupies the level of the lower key bentonite, although no recognizable bentonite was associated with it 
Pierre Shale-Continued

Mobridge Member-Continued

2. Shale, medium-brown, noncalcareous, soft, partially oxidized; white powdery gypsum(?) crystals on parting planes. At the base is a 1in. puffy-weathering heavily rust-stained bentonite layer........................

1. Shale, dark-gray, calcareous, blocky; weathers light gray; contains numerous shell fragments and specimens of Baculites clinolobatus. At the base is a discontinuous layer of 2- to 4-in.thick and 6- to 10-in.-long dense tan-weathering gray-cored limestone concretions. A similar layer is at $5 \mathrm{ft} 6 \mathrm{in}$. A persistent layer of discoidal rusty- to tan-weathering grayishtan-cored slightly calcareous concretions, similar in size to those below, is at $22 \mathrm{ft}$. At $35 \mathrm{ft} 6 \mathrm{in}$. is another concretion layer apparently similar to that at $22 \mathrm{ft}$, except that the concretion cores are purple stained, maroonish red, fractured, and noncalcareous. Numerous rusty- to tan-weathering lightbrown-cored noncalcareous to slightly calcareous concretions 1 to 3 in. thick and 4 to 12 in. long are scattered from $11 \mathrm{ft}$ to the top of the unit. Base of the unit is at the level of the railroad bed

\section{LOCALITY 39}

Section measured on a low south-facing cut on the north side of the railroad tracks in $N W 14 S E 14$ sec. $17, T .19$ N., R. 29 E., Corson County, S. Dak.

Pierre Shale:

Mobridge Member:

3. Shale, grayish-brown, calcareous, chippy; mottled with rust stain. Scattered through this unit are red-weathering brown-cored slightly calcareous to noncalcareous concretions, some of which contain casts and molds of the pelecypod Inoceramus...........

2. Shale, light-olive-gray, noncalcareous, chunky. Upper and lower contacts gradational...... .

1. Shale, dark-gray to dark-olive-gray, calcareous, chunky. A 1-in. bed of olive-green graded bentonite is at $3 \mathrm{ft}$.

Base of the unit is at the bottom of the trackside gully ..........................

Ft. In.

Pierre Shale:

Mobridge Member:

5. Shale, very dark gray, noncalcareous, chunky, heavily rust-stained; contains scattered gypsum crystals and melanterite(?); becomes caramel brown in upper $4 \mathrm{ft}$ because of oxidation. A 3-in. bed of graded bentonite, considered to be the lower key bentonite, is at the base .................

4. Shale, dark-gray, calcareous, blocky. A 1-in. bed of bentonite is at $6 \mathrm{ft} 8 \mathrm{in}$., and a 3 -in. bed of indurated marl is at $8 \mathrm{ft} 8 \mathrm{in}$. At $10 \mathrm{ft} 8 \mathrm{in}$. is a 6 -in. layer of heavily rust- and melanterite(?) stained gypsiferous noncalcareous shale; scattered rust and melanterite(?) staining occurs in the overlying 6 to $9 \mathrm{ft}$ of shale... -

3. Shale, dark-gray, noncalcareous, chunky. At the base is a $1-\mathrm{ft}$ layer of heavily rust- and melanterite(?)-stained shale, and a similar 2 -in. layer is at the top of the unit . . ......

2. Shale, dark-gray, calcareous, chunky _.........

1. Shale, maroonish brown, noncalcareous, chunky to chippy; contains scattered small oval slightly calcareous punky light-gray concretions. The lower $2 \mathrm{ft}, 8$ in. contains considerable melanterite(?), as does a $1 / 2$-in. layer of

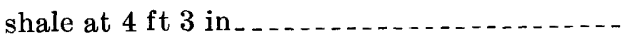

Section measured on an extensive two-level west-facing railroad cut in $S W_{1 / 4}^{1 / 4 E_{1 / 4}^{1 / 4}}$ and $N W_{1 / 4}^{1 / S E_{1 / 4}^{1 / 4}}$ sec. 3, T. 19 N., R. $29 E$. Corson County, S. Dak. Base of the section is at the level of the tracks and about 50 yards north of an unnamed tributary to Oak Creek which flows through a concrete conduit beneath the tracks, and about $50 \mathrm{ft}$ north of the southern end of the cut. Top of the section is about 50 yards farther north.

Pierre Shale:

Mobridge Member:

2. Shale, banded, noncalcareous, chippy to chunky;

Ft. In.
Ft. In 236 contains medium-gray and gray-brown beds,

$23-0730-69-8$
Ft. I7.

$\begin{array}{ll}20 & 6\end{array}$ 


\section{LOCALITY 44}

Steep extensive west-facing exposure on the east bank of Oak Creek

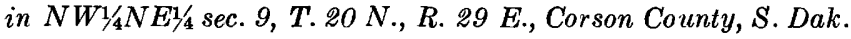

Pierre Shale:

Elk Butte Member:

10. Shale, brownish-gray, noncalcareous, chippy to chunky; weathers to a smooth slope thinly covered with light-gray shale chips. The shale is somewhat rust stained and becomes browner, presumably because of oxidation, in the upper $13 \mathrm{ft}$. At the base of this unit is a 2-in. layer of white-weathering bentonite containing spherical nodules of bladed barite $1 / 2$ to 2 in. in diameter.....-

9. Shale; medium gray when moist, light gray and hard when dry; noncalcareous, chippy to chunky; forms a steep thinly covered slope, heavily rust stained except in lower few feet where it grades into unstained shale below; contains scattered melanterite(?) in upper $8 \mathrm{ft}$

8. Shale; like unit 9 , except unstained. At the base of this unit is a 1/2-in. layer of orange nonsilty slightly waxy bentonite.........

Mobridge Member:

7. Shale; like unit 8, except calcareous. A 1/8-in. bentonite is at $3 \mathrm{ft}$, and a $3 / 4$-in. bentonite is at $6 \mathrm{ft} 3$ in. At $7 \mathrm{ft} 3$ in. is the 10 -in.-thick upper key bentonite. The lower $1 / 8$ in. is silty and biotitic and grades upward into $1 / 2$ in. of waxy green bentonite. This is abruptly overlain by $4 \mathrm{in}$. of very silty biotitic bentonite which grades upward into 5 in. of waxy nonsilty green bentonite; this in turn grades into the overlying shale. The contact of this unit with the underlying shale is

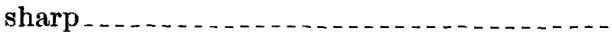

6. Shale; like upper $8 \mathrm{ft}$ of unit 9 . Lower contact

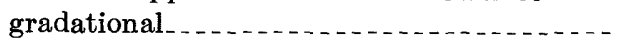

5. Shale; like unit 7

4. Shale; like unit 6. Both upper and lower con-

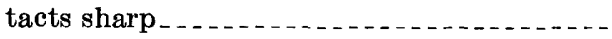

3. Shale; like unit 7. Lower contact gradational.

2. Shale; like unit 6. A 21/2- to 4-in. layer of bentonite, the lower key bentonite, is at the base

1. Shale; like unit 7. Base of the section is about $2 \mathrm{ft}$ above the bed of Oak Creek .........

\section{LOCALITY 45}

Section measured on a temporarily exposed and now covered eastfacing roadcut in the southern part of $N_{1 / 4}^{1} N W_{1 / 4}^{1 / 4 e c}$. $26, T .20$ N., R. 28 E., Corson County, S. Dak.

Pierre Shale:

Mobridge Member:

2. Shale, caramel-brown, slightly calcareous to noncalcareous, blocky, oxidized. At the base is a $1 / 2$-in. layer of yellow bentonite, and at $8 \mathrm{in}$. is the base of a 1-ft olive-green graded bentonite, considered to be the upper key bentonite

Ft. In.

12

46

20

10

120

126

$2 \quad 6$
Pierre Shale-Continued

Mobridge Member-Continued

1. Shale, dark-gray, typically calcareous, blocky, tough; becomes brownish gray in upper 10 to $15 \mathrm{ft}$. Pelecypod shell fragments and small ovoid tan calcareous perforated concretions are scattered through the unit.............

\section{LOCALITY 49}

Section measured on a moderately high extensive west-facing exposure on the east bank of Little Oak Creek in the scuthern part of SW 1/4 SE1/4 sec. 1, T. 19 N., R. 26 E., Corson County, S. Dak.

Pierre Shale:

Elk Butte Member:

Ft. In.

4. Shale, brownish-gray, noncalcareous, chunky, lightly rust-stained; browner and rather silty in upper $15 \mathrm{ft}$, browner in lower $10 \mathrm{ft}$. At $21 \mathrm{ft} 9 \mathrm{in}$. is a 1-in. layer of olive-green waxy bentonite which contains spherical nodules of bladed barite ranging from about $1 / 4$ to 2 in. in diameter. Similar nodules occur in a $1 / 8^{-i n}$. bentonite at the base of the unit. At $8 \mathrm{ft} 6 \mathrm{in}$. is a layer of purple weathering red-cored noncalcareous concretions

3. Shale; like unit 4, except with abundant rust stain on parting planes

2. Shale, dark-gray, noncalcareous, chunky, flakytextured; with scattered rust and melanter-

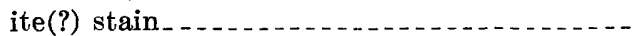

Mobridge Member:

1. Shale, dark-gray; calcareous in lower $4 \mathrm{ft}$ and upper $2 \mathrm{ft}$, otherwise noncalcareous, chunky. Noncalcareous shale flaky textured. The 4-in. upper key bentonite is at $4 \mathrm{ft}$ and is graded; basal 1 in. silty and light grayish green; becomes nonsilty and yellowish green in upper 3 in. A $1 / 4$-in. bentonite is at $6 \mathrm{ft} 8$ in., a $1 / 2$ in. grayish-green clayey bentonite is at $11 \mathrm{ft}$ 6 in., a $3 / 4$-in. heavily melanterite(?)-staired bentonite is at $11 \mathrm{ft} 9 \mathrm{in}$., and a $3 / 4$-in. grac'ed bentonite is at $12 \mathrm{ft}$. (The last three bentonites are represented by one symbol on the graphic section). The base of the unit is at the level of the bed of Little Oak Creek ..........

\section{LOCALITY 50}

Section measured on an extensive southwest-facing exposure about $1 / 2$ mile north of the Grand River in the center of $S W 1_{4}^{\prime}$; sec. 26, T. 20 N., R. 26 E., Corson County, S. Dak.

Fox Hills Sandstone:

7. Siltstone, sandy, clayey, yellowish-gray, very poorly indurated; contains scattered small lenses and blebs of dark-gray shale. Small ovoid redweathering dark-gray-cored limestone conc"etions in upper $11 / 2 \mathrm{ft} \ldots \ldots$

6. Siltstone and sandstone, subgraywacke, lightgray, grayish-yellow-weathering, very poo"ly indurated; interbeds and lenses of dark-gray very silty and sandy shale. A layer of dark-bluegray-cored silt-jacketed limestone concretions is at $4 \mathrm{ft}$. Scattered large ovoid limestone concretions occur in upper $2 \mathrm{ft}$. Lithology grades into that of overlying and underlying units...
Ft. In. 
Fox Hills Sandstone-Continued

5. Shale, dark-gray, silty to sandy; contains irregular blebs and laminae of silt and sand; light gray weathering. Purple-weathering carbonized plant fragments present. The lower $1 \mathrm{ft}$ is a ferruginous layer of interlaminated silt and sand, with some shale partings; weathers red and brown and locally forms a crumbly ledge.

4. Sandstone, light-yellowish-gray to greenish-gray, fine-grained to very fine grained, clayey, silty, somewhat glauconitic, massive, poorly indurated; mottled with clayey and silty patches except laminated to cross laminated in lower 6 in.; weathers orange brown. At $6 \mathrm{ft}$ is a semiindurated ledge of ferruginous sandstone with calcareous cement, containing red-brownweathering spherical limestone concretions, many of which contain the pelecypod Pro-

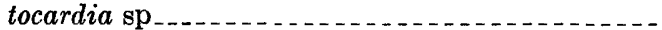

3. Siltstone, clayey, sandy, dark-gray to yellowishbrown, variegated, poorly indurated. Silt, sand, and clay intermixed in lower $10 \mathrm{ft}$ or so; in upper $14 \mathrm{ft}$ they are somewhat more segregated and give the outcrop, at least locally, an illdefined banding. Scattered silt-jacketed limestone concretions from $9 \mathrm{ft}$ to $18 \mathrm{ft}$; some con-

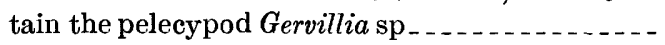

2. Shale, silty, medium-gray, semiplastic, ruststained on irregular parting surfaces, scattered melanterite(?) stain; contains scattered silt pods; weathers lighter gray than underlying Pierre Shale. Basal $1 \mathrm{ft} 7 \mathrm{in}$. is heavily melanterite(?)- and rust-stained shale. At $3 \mathrm{ft} 6$ in. is a layer of ovoid to spherical heavily silt-jacketed gray limestone concretions about $1 \mathrm{ft}$ in diameter; some contain pelecypods and the ammonite Discoscaphites nicolleti (Morton); similar concretions scattered throughout the unit..........................................

Pierre Shale:

Elk Butte Member:

1. Shale, brownish-gray, noncalcareous, very silty, blocky to chunky, rust-stained; contains scattered gypsum crystals. Silt is dispersed in the shale but is also present as pods, stringers, and burrow fillings.

The crosscutting relationship of the siltfilled burrows to the planes of bedding indicates that the sediment was considerably disturbed shortly after deposition.

The shale of unit 1 is lithologically transitional to the typical clayey silt and sand of the Fox Hills Sandstone. At this locality the contact between the Fox Hills Sandstone and the Pierre Shale may conveniently be placed at the conspicuous melanterite(?)-stained shale band at the base of unit 2.......

\section{LOCALITY 52}

Section measured about 300 yards northeast of locality 53 on a gently sloping south-facing exposure at the extreme eastern edge of $S E \frac{1}{4} S E \frac{1}{4}$ sec. 21, T. 20 N., R. 25 E., Corson County, S. Dak.

Fox Hills Sandstone:

4. Sand, very fine grained, grayish-tan, rust-stained.

Overlain by about $6 \mathrm{ft}$ of gravel

Ft. In. 14
Ft. In. Fox Hills Sandstone-Continued

Ft. Ir.

3. Silt, brownish-gray; very clayey in lower part; becomes less clayey and more sandy toward the the top. Upper and lower contacts gradational_-

Pierre Shale:

Elk Butte Member: $\begin{array}{ll}4 & 2\end{array}$

9

$24 \quad 0$

104
2. Shale, brownish-gray, noncalcareous, chunky, very silty; contains numerous silt-filled borings. Upper and lower contacts gradational

1. Shale, dark-brownish-gray, noncalcareous, chunky to flaky; slightly silty in lower $15 \mathrm{ft}$, becomes more silty toward the top; a few thin silt interbeds in upper $6 \mathrm{ft}$.

Base of the section is at the level of the top of the section at locality 53 , as determined by hand level.

\section{LOCALITY 53}

Section measured on a fairly steep west-facing exposure about $1 / 4$ mile southeast of locality 54 and about 300 yards east of the east bank of the Grand River in NE1/4NE1/4 sec. 28, T. $20 \mathrm{~N}$.. R. 25 E., Corson County, S. Dak.

Pierre Shale:

Elk Butte Member:

7. Shale, dark-gray; greenish-gray marbling in lower 5 to $10 \mathrm{ft}$ and brownish-gray marbling in upper 10 to $15 \mathrm{ft}$; noncalcareous; contains little silt or sand; chippy to chunky; slope covered by 4 to 8 inches of soil. This unit is overlain by about $3 \mathrm{ft}$ of heavily weathered shale_................................

6. Shale, dark-gray, noncalcareous; heavily rust-
stained and melanterite(?) stained except lightly to moderately stained in lower $8 \mathrm{ft}$ and upper $5 \mathrm{ft}$; slope thickly soil covered and surfaced with hardened gumbo. Contacts with overlying and underlying units gradational_.

5. Shale, medium-gray, noncalcareous, blocky to chunky; contains little silt except in lower few feet as it grades downward into silty underlying shale .......................

4. Shale, brownish-gray, noncalcareous, chunky, very silty. Becomes less silty at top and bottom of unit and grades into the adjacent

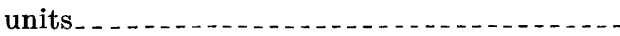

3. Shale, brownish-gray, noncalcareous, chippy to chunky; some rust stain on parting surfaces and occasional beds of browner shale

Ft. In.

23

200

$9 \quad 0$

150

2. Shale; like unit 3, except melanterite(?) stained

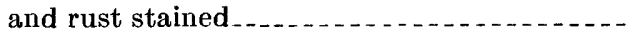

1. Shale; like unit 3.

Base of section is about $25 \mathrm{ft}$ below top of the section at locality 54 , as determined by hand level

\section{LOCALITY 54}

Section measured on a rather high very steep southwest-facin? exposure on the east bank of the Grand River in the northeast corner of $S E 1 / 4 S W 1 / 4$ sec. 21, T. 20 N., R. 25 E., Corson County, S. Dak.

Pierre Shale:

Elk Butte Member:

4. Shale, caramel-brown; sporadic brownish-gray layers, noncalcareous; typically contains con-
Ft. In. 
Pierre Shale-Continued

Elk Butte Member-Continued

4. Shale-Continued

siderable silt and (or) sand, chippy; weathers to brown soil containing many tiny shale chips. The shale between approximately 3 and $9 \mathrm{ft}$ contains less silt and (or) sand than that above or below .................

3. Shale, brownish-gray, noncalcareous; moderately rust-stained on parting surfaces; becomes siltier in upper $4 \mathrm{ft}$ and grades into the very silty overlying shale..................

2. Shale, dark-gray, noncalcareous, heavily melanterite(?)- and rust-stained; forms a steeper slope than shale above or below.

1. Shale, dark gray, typically noncalacareous, chunky to chippy; slightly rust stained above about $10 \mathrm{ft}$. Between about $4 \mathrm{ft}$ and $6 \mathrm{ft}$ the shale is slightly calacareous. Between $17 \mathrm{ft}$ and $23 \mathrm{ft}$ there are a few widely scattered 6- to 10-in-thick round tan-weathering darkgray-cored limestone concretions with bore holes in the weathered rind. At $9 \mathrm{ft}$ is a $1 / 4$-in. layer of heavily rust- and melanterite(?)stained bentonite.

Base of the section is about $2 \mathrm{ft}$ above the level of the Grand River....................

\section{REFERENCES CITED}

Albritton, C. C., Jr., Schell, W. W., Hill, C. S., and Puryear, J. R., 1954, Foraminiferal populations in the Grayson Marl [Texas]: Geol. Soc. America Bull., v. 65, no. 4, p. 327-336, 3 figs.

Allan, R. S., 1936, New records of the genus Lingula (Brachiopoda) from Tertiary strata in New Zealand: Royal Soc. New Zealand Trans., v. 65, pt. 4, p. 383-385.

Anderson, H. W., 1930, Some Cretaceous Foraminifera of South Dakota : South Dakota Geol. and Nat. History Survey Rept. Inv. $5,7 \mathrm{p} ., 10 \mathrm{pls}$.

Ansary, S. E., and Fakhr, B. Y., 1958, Maestrichtian Foraminifera from Um El Huetat area, west of Safaga: Egyptian Jour. Geology, v. 2, no. 2, p. 105-146, 2 pls., 1 fig.

Applin, E. R., 1933, A microfossiliferous Upper Cretaceous section from South Dakota: Jour. Paleontology, v. 7, no. 2, p. 215-220.

Applin, E. R., and Jordan, Louise, 1945, Diagnostic Foraminifera from subsurface formations in Florida : Jour. Paleontology, v. 19, no. 2, p. 129-148, pls. 18-21, 2 figs.

Bandy, O. L., 1951, Upper Cretaceous Foraminifera from the Carlsbad area, San Diego County, California: Jour. Paleontology. v. 25, no. 4, p. 488-513, pls. 72-75, 2 figs.

Banner, F. T., and Blow, W. H., 1959, The classification and stratigraphical distribution of the Globigerinaceae, Part 1: Palaeontology, v. 2, pt. 1, p. 1-27, 3 pls., 5 figs.

Belford, D. J., 1958, The genera Nuttallides Finlay, 1939, and Nuttallina n. gen. : Cushman Found. Foram. Research Contr., v. 9 , pt. 4 , p. $93-98$, pls. $18,19,4$ figs.

- 1959, Nuttallinella new name for Nuttallina Belford, 1958 (non Nuttallina Dall, 1871) : Cushman Found. Foram. Research Contr., v. 10, pt. 1, p. 20.

Berry, Willard, and Kelley, Louis, 1929, The Foraminifera of the Ripley formation on Coon Creek, Tennessee: U.S. Natl. Mus. Proc., v. 76, art. 19, 20 p., 3 pls.
Bolin, E. J., 1952, Microfossils of the Niobrara formation of southeastern South Dakota: South Dakota Geol. Survey Rept. Inv. 70, 74 p., 5 pls., 1 fig.

1956, Upper Cretaceous Foraminifera, Ostracoda, and Radiolaria from Minnesota: Jour. Paleontolog.7, v. 30, no. 2, p. 278-298, pls. 37-39, 5 figs.

Bolli, H. M., Loeblich, A. R., Jr., and Tappan, Helen, 1957, Planktonic foraminiferal families Hantkeninidae, Orbulinidae, Globorotaliidae, and Globotruncanidae, in Loeblich, A. R., Jr., Studies in Foraminifera : U.S. Natl. Mus. Bull. 215, p. 3-50, pls. 1-11, figs. 1-9.

Bowen, R. N. C., 1955, Observations on the foraminiferal genus Gaudryina d’Orbigny, 1839: Micropaleontology, v. 1, no. 4, p. 359-364, figs. 1-6.

Brady. H. B., 1881, Notes on some reticularian Rhizopoda of the Ohallenger Expedition: Micros. Sci. Quart. Jour., new ser., v. 21, p. 31-71.

Brotzen, Fritz, 1936. Foraminiferen aus dem Schwedischen Untersten Senon von Eriksdal in Schonen: Sveriges geol. undersökning, ser. C. no. 396 (Arsb. 30, no. 3), 206 p., 14 pls., 69 figs.

Bullard, F. J., 1953, Polymorphinidae of the Cretacsous (Cenomanian) Del Rio shale [Texas] : Jour. Paleontology, v. 27, 110. 3, p. 338-346, pls. 45, 46, 1 fig.

Carman, Katherine W., 1929, Some Foraminifera fr?m the Niobrara and Benton formations of Wyoming: Jour. Paleontology, v. 3, no. 3, p. 309-315, pl. 34.

Church. C. C., 1952, Cretaceous Foraminifera from the Franciscan Calera Limestone of California: Cushman Found. Foram. Research Contr., v. 3, pt. 2, p. 68-70, 2 figs.

Cifelli, Richard, 1960, Variation of English Bathonian Lagenidae and its phylogenetic significance: Jour. P গleontology, v. 34, no. 3, p. 556-569, 6 figs.

Cobban, W. A., 1958, Late Cretaceous fossil zones of the Powder River Basin, Wyoming and Montana, in Wyoming Geol. Assoc. Guidebook, 13th Ann. Field Conf., Powder River Basin, 1958: p. 114-119, 2 figs.

Cobban, W. A., and Reeside, J. B., Jr., 1952, Correlation of the Cretaceous formations of the western interior of the United States: Geol. Soc. America Bull., v. 63, no. 10, p. 1011-1043.

Cole, W. S., 1938, Stratigraphy and micropaleonto'ngy of two deep wells in Florida : Florida Dept. Conserv., Geol. Dept. Bull. 16, 73 p., 12 pls., 3 figs.

Cooper, G. A., 1937, Brachiopod ecology and paleoecology, in Natl. Research Council, Comm. on Paleoecology Report, 1936-1937 : p. 26-53.

Crandell, D. R., 1950. Revision of Pierre Shale of central South Dakota: Am. Assoc. Petroleum Geologists Bull., v. 34, no. 12. p. 2337-2346, 2 figs.

1952, Origin of Crow Creek member of Pierre Shale in central South Dakota: Am. Assoc. Petroleum Geologists Bull., v. 36, no. 9, p. 1754-1765, 3 figs.

1958, Geology of the Pierre area, South Dakota: U.S. Geol. Survey Prof. Paper 307, 83 p., 3 pls., 32 figs. [1959].

Cushman, J. A., 1910, A monograph of the Foraminifera of the North Pacific Ocean, Part 1, Astrorhizidae and Iituolidae: U.S. Natl. Mus., Bull. 71, 134 p., 203 figs.

1913, A monograph of the Foraminifera of the North Pacific Ocean, Part 3, Lagenidae: U.S. Natl. Mus. Bull. 71, 118 p., 47 pls.

1931a, A preliminary report on the Foraminifera of Tennessee : Tennessee Div. Geology Bull. 41,116 p., 13 pls.

1931b, The Foraminifera of the Saratoga Chalk; Jour. Paleontology, v. 5, no. 4, p. 297-315, pls. 34-36. 
1936, Geology and paleontology of the Georges Bank canyons ; Pt. 4, Cretaceous and late Tertiary Foraminifera : Geol. Soc. America Bull, v. 47, no. 3, p. 413-440, 5 pls.

1937, A few new species of American Cretaceous Foraminifera : Cushman Lab. Foram. Research Contr., v. 13, pt. 4, p. 100-105, pl. 15.

1938a, Additional new species of American Cretaceous Foraminifera: Cushman Lab. Foram. Research Contr., v. 14, pt. 2, p. 31-50, pls. 5-8.

$1938 \mathrm{~b}$, Some new species of rotaliform Foraminifera from the American Cretaceous: Cushman Lab. Foram. Research Contr., v. 14, pt. 3, p. 66-71, pls. 11-12.

1944a, The foraminiferal fauna of the type locality of the Pecan Gap chalk [Texas]: Cushman Lab. Foram. Research Contr., v. 20, pt. 1, p. 1-17, pls. 1-3.

- 1944b, Foraminifera of the lower part of the Mooreville chalk of the Selma group of Mississippi: Cushman Lab. Foran. Research Contr.. v. 20, pt. 4, p. 83-96, pls. 13, 14. [These faunas are included in Cushman, 1946, cited below].

-1945 , The species of Foraminifera recorded by d'Orbigny in 1826 from the Pliocene of Castel Arquato, Italy : Cushman Lab. Foram. Research Spec. Pub. 13, p. 1-27, 6 pls.

1946, Upper Cretaceous Foraminifera of the Gulf Coastal region of the United States and adjacent areas: U.S. Geol. Survey Prof. Paper 206, 241, p., 66 pls.

1948a, Foraminifera from the Hammond well [Maryland]: Maryland Dept. Geology, Mines and Water Resources Bull. 2, p. 213-267, pls. 15-26, figs. 25-27.

1948b, Foraminifera, their classification and economic use [4th ed.]: Cambridge, Mass., Harvard Univ. Press, $605 \mathrm{p}$.

1949, The foraminiferal fauna of the Upper Cretaceous Arkadelphia marl of Arkansas: U.S. Geol. Survey Prof. Paper 221-A, 19 p., 4 pls.

Cushman, J. A., and Campbell, A. S., 1935, Cretaceous Foraminifera from the Moreno shale of California: Cushman Lab. Foram. Research Contr., v. 11, pt. 3, p. 65-73, pls. 10, 11.

Cushman, J. A. and Church, C. C., 1929, Some Upper Cretaceous Foraminifera from near Coalinga: California Acad. Sci. Proc., 4th ser., v. 18, no. 16, p. 497-530, pls. 36-11.

Cushman, J. A., and Deaderick, W. H., 1944, Cretaceous Foraminifera from the Marlbrook marl of Arkansas: Jour. Paleontology, v. 18, no. 4, p. 328-342, pls. 50-53.

Cushman, J. A., and Goudkoff, P. P., 1944, Some Foraminifera from the Upper Cretaceous of California : Cushman Lab. Foram. Research Contr., v. 20, pt. 3, p. 53-64, pls. 9, 10.

Cushman, J. A., and Jarvis, P. W., 1932, Upper Cretaceous Foraminifera from Trinidad: U.S. Natl. Mus. Proc., v. 80, art. 14,60 p. 16 pls.

Cushman, J. A., and Ozawa, Yoshiaki, 1930, A monograph of the foraminiferal family Polymorphinidae, recent and fossil : U.S. Natl. Mus. Proc., v. 77, art. 6, 195 p., 40 pls.

Cushman, J. A., and Parker, F. L., 1936, notes on some Cretaceous species of Buliminella and Neobulimina: Cushman Lab. Foram. Research Contr., v. 12, pt. 1, p. 5-10, pl. 2.

Cushman, J. A., and Renz, H. H., 1946, The foraminiferal fauna of the Lizard Springs Formation of Trinidad, British West Indies: Cushman Lab. Foram. Research Spec. Pub. 18, p. $1-\mathbf{1 8 , 8}$ pls., map.

1947, Further notes on the Cretaceous Foraminifera of Trinidad: Cushman Lab. Foram. Research Contr., v. 23, pt. 2, p. 31-51, pls. 11, 12.
Cushman, J. A., and Todd, Ruth, 1943, The genus Pullenia and its species: Cushman Lab. Foram. Research Contr., v. 19, pt. 1, p. 1-23, 4 pls.

Deshayes, G. P., 1832, Encyclopédie méthođique: Histoire naturelle des vers: Paris, Mme. v. Agasse, v. 3, p. 1107.

Dunbar, C. O., and Rodgers, John, 1957, Principles of stratigraphy : New York, John Wiley \& Sons, $356 \mathrm{p}$.

Edgell, H. S., 1954, The stratigraphical value of Bolivinoide? in the Upper Cretaceous of northwest Australia : Cushmar Found. Foram. Research Contr., v. 5, pt. 2, p. 68-76, pls 13, 14, 5 figs.

Eicher, D. L., 1960, Stratigraphy and micropaleontology of the Thermopolis Shale [Wyoming]: Yale Univ. Peabody Mus. Nat. History Bull. 15, 126 p., 6 pls., 12 figs.

Ellis, B. F., and Messina, A. R., 1940-1964, Catalogue of Foraminifera : Am. Mus. Nat. History Spec. Pub.

Finlay, H. J., 1947, New Zealand Foraminifera ; Key species in stratigraphy, no. 5: New Zealand Jour. Sci. and Technology, v. 28, no. 5, p. 259-292, 9 pls.

Fox, S. K., Jr., 1954, Cretaceous Foraminifera from the Greenhorn, Carlile, and Cody formations, South Dakota, Wycming: U.S. Geol. Survey Prof. Paper 254-E, p. 97-124, pls. 24-26.

Franke, Adolf, 1936, Die Foraminiferen des Deutschen Lias: Preussische Geol. Landesanstalt Abh., no. 169, 138 p., 12 pls., 2 figs.

Fukuta, Osamu, 1957, Upper Cretaceous Foraminifera from the Rumoi coal field, Hokkaido, Japan : Japan Geol. Survey Rept. 172, 18 p., pl. 1, fig. 1.

Glazunova, A. E., Balakhmatova, V. T., Lipman, R. Kh., Romanova, V. I., and Chochlova, I. A., 1960. Stratigrafia i fauna melovykh otlozhenii Zapadno-Sibirskoi nizmennosti [Stratigraphy and fauna of the Cretaceous deposits of the Western Siberian lowland] : Vsesnoyuznyi Nauchno-Isslodovatelskii Geol. Inst. Trudy, new ser., v. 29, 347 p., 52 pls., 13 figs.

Graham, J. J., 1962, A review of the planktonic Foraminifera from the Upper Cretaceous of California : Cushman Foun'. Foram. Research Contr., v. 13, pt. 3, p. 100-109, pls. 19, 27.

Graham, J. J., and Clark, D. K., 1961, New evidence for the age of the "G-1 zone" in the Upper Cretaceous of Californis : Cushman Found. Foram. Research Contr., v. 12, pt. 3, p. 107-114, pl. 5, 2 figs.

Gries, J. P., 1942, Economic possibilities of the Pierre Shale: Sonth Dakota Geol. Survey Rept. Inv. 43, 79 p., 1 pl., 11 figs.

Grunseth, A. C., 1955, Foraminifera of the Niobrara Formation of northeastern North Dakota: Compass, v. 32, no. 2, p. 120-132, 2 pls.

Hagenow, Friedrich von, 1842, Cephalopoda foraminifera d'Orth. Rhizopoda Dujard., Bryozoa polythalamia Ehrenb., Part E of Monographie der Rügen'schen Kreide-Versteinerunge $\eta$, III, Abtheilung, Mollusken: Neues Jahrb. Mineralogie, Geognosie, Geologie u. Petrefakten-Kunde, Jahrg. 1842, p. 568-574.

Hagn, Herbert, 1953, Die Foraminiferen der Pinswanger Schichten (unteres Obercampan) : Palaeontographica, v. 104, pt. A, p. 1-114, pls. 1-8, figs. 1-27.

Hamilton. E. L., 1953, Upper Cretaceous, Tertiary, and Recent planktonic Foraminifera from mid-Pacific fiat-topped seamounts: Jour. Paleontology, v. 27, no. 2, p. 204-237, pls. 2n32, figs. 1-4b. 
Hiltermann, Heinrich, 1963, Zur Entwicklung der BenthosForaminifere Bolivinoides, in Koenigswald, G. H. R. von, and others, eds., Evolutionary trends in Foraminifera: Amsterdam, Elsevier Publishing Co., p. 198-223, pls. 1-4.

Hofker, Jan, 1956a, Die Pseudotextularia-Zone der Bohrung Maasbüll I und ihre Foraminiferen-Fauna : Paläont. Zeitschr., v. 30, Sonderheft, p. 59-78, pls. 5-10, 1 fig.

- 1958, Upper Cretaceous Bolivinoides guideforms: Micropaleontology, v. 4, no. 3, p. 329-331, 2 pls.

1960, The taxonomic status of Praeglobotruncana, Planomalina, Globigerinella, and Biglobigerinella: Micropaleontology, v. 6, no. 3, p. 315-322, 2 pls., 1 fig.

Jennings, P. H., 1936, A microfauna from the Monmouth and basal Rancocas groups of New Jersey: Bull. Am. Paleontology, v. 23, no. 78, p. 1-76, 7 pls.

Johnson, R. G., 1960, Models and methods for analysis of the mode of formation of fossil assemblages: Geol. Soc. America Bull., v. 71, no. 7, p. 1075-1085, 2 figs.

Jones, D. J., ed., 1953, Microfossils of the Upper Cretaceous of northeastern Utah and southwestern Wyoming: Utah Geol. and Mineralog. Survey Bull. 47, 158 p., 16 pls., 8 figs.

Jordan, R. R., 1962, Planktonic Foraminifera and the CretaceousTertiary boundary in central Delaware: Delaware Geol. Survey Rept. Inv. 5, 13 p., 2 pls., 2 figs.

Koldewijn, B. W., 1958, Sediments of the Paria-Trinidad shelf, v. 3 of Reports of the Orinoco Shelf Expedition: The Hague, Mouton \& Co., $107 \mathrm{p} ., 11 \mathrm{pls}$.

Lalicker, C. G., 1948, A new genus of Foraminifera from the Upper Cretaceous [Arkansas]: Jour. Paleontology, v. 22, no. 5 , p. 624 , pl. 92.

Loeblich, A. R., Jr., 1946, Foraminifera from the type Pepper shale of Texas: Jour. Paleontology, v. 20, no. 2, p. 130-139, pl. 22,3 figs.

Loeblich, A. R., Jr., and Tappan, Helen, 1949, Foraminifera from the Walnut Formation (Lower Gretaceous) of northern Texas and southern Oklahoma: Jour. Paleontology, v. 23, no. 3, p. 245-266, pls. 46-51.

1955, A revision of some glanduline Nodosariidae (Foraminifera) : Smithsonian Misc. Colln., v. 126, no. 3, p. 1-9, $1 \mathrm{pl}$.

1957, Eleven new genera of Foraminifera, in Loeblich, A. R., Jr., and others, Studies in Foraminifera: U.S. Natl. Mus. Bull. 215, p. 223-232, pls. 72, 73, fig. 30.

Loeblich, A. R., Jr., Tappan, Helen, and others, 1964, Protista 2, Sarcodina, chiefiy "Thecamoebians" and Foraminiferida, Part O of Moore, R. C., ed., Treatise on invertebrate paleontology : New York and Lawrence, Kans., Geol. Soc. America and Univ. Kansas Press, 2 v., $900 \mathrm{p}$.

Loetterle, G. J., 1937, The micropaleontology of the Niobrara formation in Kansas, Nebraska, and South Dakota: Nebraska Geol. Survey Bull. 12, 2d ser., 73 p., 11 pls., 3 figs.

Lowman, S. W., 1949, Sedimentary facies in Gulf Coast: Am. Assoc. Petroleum Geologists Bull., v. 33, no. 12, p. 1939-1997, 35 figs.

Marie, Pierre, 1938, Sur quelques foraminifères nouveaux ou peu connus du crétacé du bassin de Paris: Soc. Géol. France Bull., 5th ser., v. 8, pt. 1-2, p. 91-104, pls. 7, 8.

_ 1941 , Les foraminifères de la Craie à Belemnitella mucronata du bassin de Paris: Mus. Histoire Naturelle Mém., new ser., r. 12, pt. 1, p. 1-296, 37 pls., 4 figs.
Meek, F. B., 1876, A report on the invertebrate Cretaceous and Tertiary fossils of the upper Missouri country : U.S. Geol. Survey Territories (Hayden) Rept. 9, 629 p., 44 pls.

Meek, F. B., and Hayden, F. V., 1856, Descriptions of new species of Gastropoda from Cretaceous formations of Nebraska Territory : Acad. Nat. Sci. Philadelphia Proc., v. 8, p. 63-69. 1861, Descriptions of new Lower Silurian (Primordial), Jurassic, Cretaceous, and Tertiry fossils, collected in Nebraska Territory, with some remarks on the rocks from which they were obtained: Acad. Nat. Sci. Philadelphia Proc., v. 13, p. 415-447.

Montanaro-Gallitelli, Eugenia, 1957, A revision of the foraminiferal family Heterohelicidae, in Loeblich, A. R., Jr., and others, Studies in Foraminifera : U.S. Natl. Mus. Bull. 215, p. 133-154, pls. 31-34.

Morrow, A. L., 1934, Foraminifera and Ostracoda from the Upper Cretaceous of Kansas : Jour. Paleontology, v. 8, no. 2, p. 186205, pls. 29-31.

Nauss, A. W., 1947, Cretaceous microfossils of the Vermilion area, Alberta: Jour. Paleontology, v. 21, no. 4. p. 329-343, pls. $48,49,3$ figs.

Niino, Hiroshi, and Emery, K. O., 1961, Sediments of the shallow portions of East China Sea and South China Se? : Geol. Soc. America Bull., v. 72, no. 5, p. 731-762, 21 figs.

Nota. D. J. G., 1958, Sediments of the western Gui?na shelf, $\nabla$. 2 of Reports of the Orinoco Shelf Expedition: Wageningen (Nederland), Landbouwhogeschool Mededel. $5 \varepsilon$, pt. 2, 98 p., 12 photos, 39 figs., 4 charts.

Olsson, R. K., 1960, Foraminifera of latest Cretaceo"s and earliest Tertiary age in the New Jersey Coastal Plain: Jour. Paleontology, v. 34, no. 1, p. 1-58, 12 pls., 2 figs.

Orbigny, A. D. d'. 1826, Tableau méthodique de la classe de Céphalopodes: Annales Sci. Nat., v. 7, p. 245-314, pls. 10-17.

Parker. F. L., and Athearn, W. D., 1959, Ecologv of marsh Foraminifera in Poponesset Bay, Massachuretts: Jour. Paleontology, v. 33, p. 333-343, pl. 50, 5 figs.

Parr, W. J., 1947, The Lagenid Foraminifera and their relationships: Royal Soc. Victoria Proc. v. 58, rt. 1-2 (new ser.), p. 116-133, pls. 6, 7, 1 fig.

Perlmutter, N. M., and Todd, Ruth, 1965; Correlatior and Foraminifera of the Monmouth Group (Upper Cretareous) Long Island, New York: U.S. Geol. Survey Prof. Paper 483-I, p. 1-21, 8 pls.

Pessagno, E. A., Jr., 1960, Stratigraphy and micropaleontology of the Cretaceous and lower Tertiary of Puerto Rico : Micropaleontology, v. 6, no. 1, p. 87-110, 5 pls., 10 figs.

Petsch, B. C., 1946, Geology of the Missouri Valley in South Dakota: South Dakota Geol. Survey Rept. Irv. 53, 78 p., 29 figs.

Phleger, F. B., 1960a, Ecology and distribution of Recent Foraminifera: Baltimore, Johns Hopkins Press, 297 p.

- 1960b, Sedimentary patterns of microfaunas in northern Gulf of Mexico, in Shepard, F. P., and others, eds., Recent sediments, northwest Gulf of Mexico: Tulsa. Am. Assoc. Petroleum Geologists, p. 267-301, 6 pls., 16 figs.

Plummer, H. J., 1926, Foraminifera of the Midwey formation in Texas: Texas Univ. Bull. 2644, 206 p., 15 pls., 13 figs. [1927].

1931, Some Cretaceous Foraminifera in $\mathbf{T}$ xas: Texas Univ. Bull. 3101, p. 109-203, pls. 8-15, 1 fig. 
Reeside, J. B., Jr., 1957, Paleoecology of the Cretaceous seas of the western interior of the United States, in Ladd, H. S., ed., Paleoecology : Geol. Soc. America Mem. 67, p. 505-541, 21 figs.

Reuss, A. E., 1861, Paläontologische Beitrage : Akad. Wiss. Wien Sitzungsber., v. 44, pt. 1, p. 301-342, pls. 1-8 [1862].

Rompf, Irene, 1960, Foraminiferen aus dem Cenoman von Sachsen, unter besonderer Berüicksichtigung der Umgebung von Dresden : Freiberger Forschungshefte, C89, p. 8-123, 22 pls., 7 figs.

Rothrock, E. P., 1947, Geology of the Missouri Valley and vicinity near Mobridge [S. Dak.]: South Dakota Geol. Survey Rept. Inv. 58, 29 p., 5 figs.

Rubey, W. W., 1929, Origin of the siliceous Mowry shale of the Black Hills region: U.S. Geol. Survey Prof. Paper 154-D, p. 153-170, 3 pls [1930].

Rudwick, M. J. S., 1965, Ecology and paleoecology, in Williams, Alwyn, and others, Brachiopoda, Part $\mathrm{H}$ of Moore, R. C., ed., Treatise on invertebrate paleontology: New York and Lawrence, Kans., Geol. Soc. America and Univ. Kansas Press, p. H199-H213.

Sandidge, J. R., 1932, Additional Foraninifera from the Ripley formation in Alabama: Am. Midland Naturalist, v. 13, no. 6, p. 333-377, pls. 31-33.

Schenck, H. G., 1943, Acila princeps, a new Upper Cretaceous pelecypod from California: Jour. Paleontology, v. 17. no. 1 , p. $60-68$, pls. $8,9,2$ figs.

Scruton, P. C., 1960, Delta building and the deltaic sequence. in Shepard, F. P., and others, eds., Recent sediments, northwest Gulf of Mexico; Tulsa, Am. Assoc. Petroleum Geologists, p. 82-102, 17 figs.

Searight, W. V., 1937, Lithologic stratigraphy of the Pierre formation of the Missouri Valley in South Dakota: South Dakota Geol. Survey Rept. Inv. 27, 63 p., 8 pls.

-1938, The microfauna of the Sully member of the Pierre: Iowa Acad. Sci. Proc., v. 45, p. 135-137 [1939?]

Shaw, A. B., 1953, Preliminary survey of the Foraminifera of the lower shale of the Niobrara formation in the Laramie Basin, in Wyoming Geol. Assoc. Guidebook 8th Ann. Field Conf., Laramie Basin, Wyoming, and North Park, Colorado, 1953 : p. 47-55, 2 pls., 1 fig.

Shepard, F. P., 1956, Marginal sediments of Mississippi Delta [Louisiana] : Am. Assoc. Petroleum Geologists Bull,, v. 40, no. 11 , p. 2537-2623, 7 pls., 46 figs.

Shepard, F. P., and Moore, D. G., 1955, Central Texas coast sedimentation-characteristics of sedimentary environment, recent history, and diagenesis: Am. Assoc. Petroleum Geologists Bull., v. 39, no. 8, p. 1463-1593, figs. 1-75.

Stainforth, R. M., 1952a, Classification of uniserial calcareous Foraminifera : Cushman Found. Foram. Research Contr.. v. 3, pt. 1, p. 6-14, 1 fig.

1952b, Nodosaria nomenclature: Cushman Found. Foram. Research Contr., v. 3, pt. 3-4, p. 146.

Stelck, C. R., and Wall, J. H., 1954, Kaskapau Foraminifera from Peace River area of western Canada [Alberta-British Columbia ] : Research Council Alberta Rept. 68, p. 4-38, 5 figs., 2 pIs.

1955, Foraminifera of the Cenomanian Dunveganoceras zone from Peace River area of western Canada [AlbertaBritish Columbia]: Research Council Alberta Rept. 70, p. 4-81, 9 pls., 6 figs.
Stephenson, L. W., King, P. B., Monroe, W. H., and Imlay, R. W., 1942, Correlation of the outcropping Cretaceous formations of the Atlantic and Gulf Coastal Plain and trans-Pecos Texas: Geol. Soc. America Bull., v. 53, no. 3, p. 435-448, chart 9.

Stoll, N. R., Dollfus, R. Ph., Forest, J., Riley, N. D., Sabrosky, C. W., Wright, C. W., and Melville, R. V., 1961, International Code of Zoological Nomenclature adopted by the XV International Congress of Zoology; London, International Trust for Zoological Nomenclature, $176 \mathrm{p}$.

Tappan, Helen, 1910, Foraminifera from the Grayson Formation of northern Texas: Jour. Paleontology, v. 14, no. 2, p. 93-126, pls. 14-19.

1943, Foraminifera from the Duck Creek formation of Oklahoma and Texas: Jour. Paleontology, v. 17, no. 5, p 476-517, pls. 77-83.

1951, Northern Alaska index Foraminifera: Cushmar Found. Foram. Research Contr., v. 2, pt. 1, p. 1-8.

1957, New Cretaceous index Foraminifera from northerr Alaska in Loeblich, A. R., Jr., and others, Studies in Foram. inifera : U.S. Natl. Mus. Bull. 215, p. 201-222, pls. 65-71, fig. 29.

1962, Foraminifera from the Arctic slope of Alaska. Part 3, Cretaceous Foraminifera: U.S. Geol. Survey Prof. Paper 236-C, p. 91-209, pls. 29-58, figs. 10-18.

Tate, Ralph, and Blake, J. F., 1876, The Yorkshire Lias : Londor, John van Voorst, 475 p., 19 pls., 9 figs.

Tourtelot, H. A., 1962, Preliminary investigation of the geologis setting and chemical composition of the Pierre shale, Great Plains region: U.S. Geol. Survey Prof. Paper 390, 74 p., 4 pls., 22 figs.

Troelsen, J. C., 1954, Studies on Ceratobuliminidae (Foraminifera) : Dansk Geol. Foren. Medd., v. 12, no. 4, p. 448-47\%, pls. 10, 11, 5 figs.

Trujillo, E. F., 1960, Upper Cretaceous Foraminifera from near Redding, Shasta County, California : Jour. Paleontology, v. 34 , no. 2, p. 290-346, pls. 43-50, 3 figs.

Waagé, K. M., 1961, The Fox Hills formation in its type aree. central South Dakota, in Wyoming Geol. Assoc. Guidebool: 16th Ann. Field Conf., Green River, Washakie, Wind River and Powder River Basins, 1961 : p. 229-240, 5 figs.

Wall, J. H., 1960, Upper Cretaceous Foraminifera from the Smoky River area, Alberta : Research Council Alberta Bull. 6,43 p., 5 pls. 1 fig.

Weimer, R. J., 1960, Upper Cretaceous stratigraphy, Rock $\mathbf{y}$ Mountain area: Am. Assoc. Petroleum Geologists Bull., v. 44, no. 1, p. 1-20, 10 figs.

White, M. P., 1928, Some index Foraminifera of the Tampico Embayment area of Mexico: Jour. Paleontology, v. 2, no. 3, p. 177-215, pls. 27-29.

Wickenden, R. T. D., 1932a, New species of Foraminifera from the Upper Cretaceous of the Prairie Provinces: Royal Son. Canada Trans., 3d ser., v. 26, sec. 4, p. 85-92, 1 pl.

- 1932b, A useful Foraminifera horizon in the Alberta shale of southern Alberta: Jour. Paleontology, v. 6, no. 2, p. 20尺207, pl. 29.

1945, Mesozoic stratigraphy of the eastern plains, Maritoba and Saskatchewan: Canada Geol. Survey Mem. 23? Pub. 2472, 85 p. pls., 1 fig. 
FORAMINIFERA, STRATIGRAPHY, PIERRE SHALE, FOX HILLS SANDSTONE, S. DAK.

Yoshida, Saburo, 1958, The foraminiferal fauna of the Upper Cretaceous Hamanaka and Kiritappu formations of eastern Hokkaido, Japan : Hokkaido Gakugei Univ. Jour., v. 9, no. 1, p. 250-264, 3 pls., 2 figs.

Young, Keith, 1951, Foraminifera and stratigraphy of the Frontier formation (Upper Cretaceous), southern Montana: Jour. Paleontology, v. 25, no. 1, p. 35-68, pls. 11-14, 6 figs.
ZoBell, C. E., 1942, Changes produced by microorganisms in sediments after deposition: Jour. Sed. Petrology, v. 12, no. 3, p. 127-136, 1 fig.

1946, Studies on redox potential of marine sediments : Am. Assoc. Petroleum Geologists Bull., v. 30, no. 4, p. 477513, 5 figs. 


\section{INDEX}

[Italic page numbers indicate major references and descriptions]

A
Acknowledgments.....
aculeata, Ramulina
acuta, Pseudoglandulina
affinis, Nodosaria
albertensis, Quadrimorphina
algeriana, Globigerinelloides
Allomorphina minuta.
allomorphinoides, Discorbina
$\quad$ Discorbis . .
Quadrimorphina
Valvulina
Valvulineria

alpha, Neobulimina canadensis.... 78, 79, 80; pl. 9 americana, Drepanochilus................... 38 Goniomya. . . Heterostomella................... 17, 50; pl. 5

Pullenia

Ammodiscidae . . . . .

Ammodiscus............................... 41 cretaceus.............. . 17, 21, 22, 41,42; pl. 4

Anomalina . . coonensis

harperi.

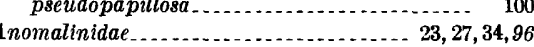

Anomalinoides . ............................... 96

minuta.................... 96, 97; pls. 2, 3

apiculata, Lagena............ 17, 21, 66; pl. 7 Oolina........

appressa, Rectoglandulina........ 18,62,63; pl. 7 archiaciana, Frondicularia........... 17, 65; pl. 7 arctica, Reophax.......................... 41 ariminensis, Planulina.......... 97 arkadelphiana, Bulimina ......... 16, 17, 77 ; pl. 8 midwayensis, Bulimina.............. 77

Asciocythere sp............................... 39

aspera, Bulimina....................... 76 Globigerinella ....................... 95,96 Nodosaria . . . . inflata, Eouvigerina ............. 18, 74; pl. 8

Astacolus........ $55,56,57,58$ crepidulus............................. 56

cretaceus ....................... 15, 17, $56 ; \mathrm{pl} .6$

dissonus ............... 16, 17, 58; pl. 6

jarvisellus .................. 16, 17,57; pl. 6

jarvisi_................................ 57

navarroanus................. 16, 17,57; pl. 6

recta

rectus ..........

taylorensis.

54
97

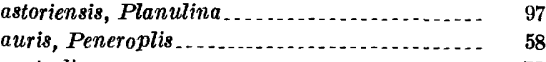

australis

Bolivinoides decorata

decoratus ....................... 18, 73; pl. 8

B

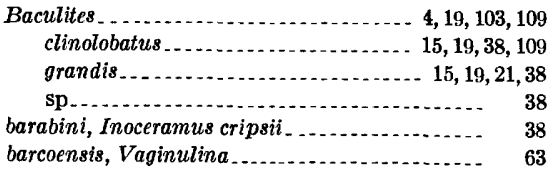

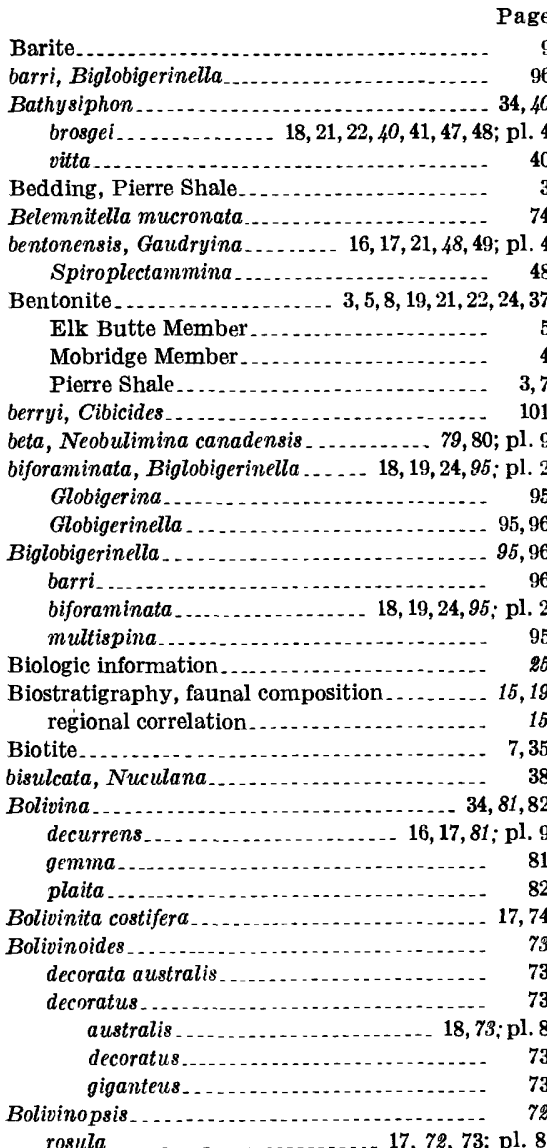

rosula ...................... 17, 72, 73; pl. 8 bonanzaensis, Haplophragmoides _. 18, 22, 49, 44; pl. 4 boweni, Gaudryina ............... 17, 47, 48; pl.4 Brachycythere............................... 39 sphenoides.................. 38 brosgei, Bathysiphon..................... 18 Bucella........................

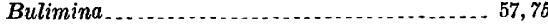
arkadelphiana $\ldots \ldots \ldots \ldots \ldots \ldots, 17,77 ; \mathrm{pl} .8$ midwayensis................... 77 aspera................................. 76 kickapooensis ............. 17 $21,23,26,75,76,77 ; \mathrm{pl} .8$ pingua ... ........... prolixa... reussi................................... 75 navarroensis............... 16, 17, 75, pl. 9 Buliminella carseyae..................... 75 carseyae plana........................ 17,75 Buliminidae ..................... 21, 23, 27, 34,74

\section{C}

Calcareous biofacies................ 21, 22, 26, 37 Calcite . . . . . . . . . . . californica, Silicosigmoilina..........
Page

Callista pellucida alpha, Neobulimina $78,79,80 ; \mathrm{pl} .9$ beta, Neobulimina ................. 79,$80 ;$ pl. 9 caracolla, Epistomina $. . . . . . . . . . . . . . . . ~ 17,92,9 ?$ Gyroidina carseyae, Buliminella plana, Buliminella catenula, Dentalina ................. 17, 58; pl. 6 Ceratobuliminidae.......................... 23, 9 ? charoides, Glomospira................. 18, 42; pl. 4 Trochammina squamata......... 4 ? corona, Glomospira

Chilostomellidae........................ 23, 27,9?

Cibicides . . . . berryi $\ldots$ coonensis_........................... 100, $10^{\circ}$ harperi........ 16, 17, 21, 23, 26, 100; pl. 11 mobridgensis................... 99; pls. 3,11 subcarinatus ..... 17,22, 23, 26, 100, 101; pl. 3 Citharina................................ 68,61

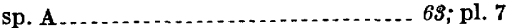
sp. B . . . . . . . . . . 7 citriformis, Lagena . . . . Clavulina trilatera . . ....................... 51 trilatera concava ......................... 59

Clavulinoides.............................. 5 \} trilatera concava................ 50 trilaterus . . . ..................... 17, 50; 1 Clay ............................... $3 i$ clinolobatus, Baculites................ 15, 19,38,10? Cobban, W. A., quoted ................... 13 cocoaensis, Planulina ........... Comparison, fossil and Recent faunas....... 23

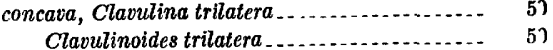

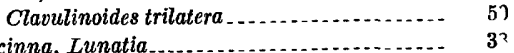

concinna, Lunatia......... 3, 5,8,22

Elk Butte Member

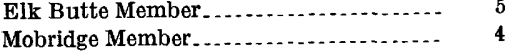

Pierre Shale _...........

Virgin Creek Member.................. 4 consobrina, Dentalina . . . . . . Contact, calcareous biofacies-upper arenaceous biofacies.....................

Elk Butte Member--Fox Hills Sandstone. Mobridge Member.

Mobridge Member-Elk Butte Member...

Mobridge Member-Virgin Creek Member-

Pierre Shale-Fox Hills Sandstone . ......

Virgin Creek Member-Verendrye Member....

coonensis, Anomalina Cibicides............. 100,10

Truncatulina . ........................... 100, 10 corona, Glomospira charoides................ 4 ? coronula, Nuttalinella.................... 9 ? Correlation, faunal evidence................ 15 Corson County, S. Dak ................... 2 costifera, Bolivinita......................... 17,71 Tappanina..................... 16, 17, 74; pl. 8 Crandell, D. R., quoted.... 5 crepidula, Nautilus . . ..................... $55,56,5$ crepidulus, Astacolus. 
PLATES 1-11 


\section{PLATE 1}

Figure 1. Verneuilinoides ef. V. perplexus (Loeblich) (p. 46).

USNM 642573. Locality 53, sample 13. a, side view; b, apertural view. $\times 112$.

2. Pseudoclavulina? meidamos Mello, n. sp. (p. 49).

Paratype, USNM 642580. Locality 41, sample 1. a, b, side views; c, apertural view. $\times 148$.

3. Clavulinoides trilaterus (Cushman) (p. 50).

USNM 642583. Locality 3 , sample 22 . a, side view; b, apertural view. $\times 56$.

4. Trochammina globigeriniformis Cushman (p. 52).

USNM 642587. Locality 54, sample 5. a, spiral side view; b, edge view; c, umbilical side view. $\times 190$.

5. Oolina obeliscata Mello, n. sp. (p. 66).

Holotype, USNM 642625. Locality 27 , sample 6. a, apertural view; $b$, side view, with internal tube visible through etched opening. $\times 220$.

6, 7. Fissurina sp. A (p. 67).

6. Side view of complete specimen, USNM 642627. Locality 41, sample 9. $\times 275$.

7. Oblique side view of etched specimen showing saddle-shaped opening of internal tube, USNM 642691. Locality 41, sample 9. $\times 275$.

8. ?Loxostoma plaita (Carsey) (p. 83).

USNM 642656. Locality $27 \mathrm{~A}$, sample 7. a, side view; b, edge view. $\times 194$.

9. "Discorbis" quadrilobus Mello, n. sp. (p. 91).

Holotype, USNM 642665. Locality 7, sample 5. a, edge view; b, umbilical side view; c, spiral side view. $\times 240$. 


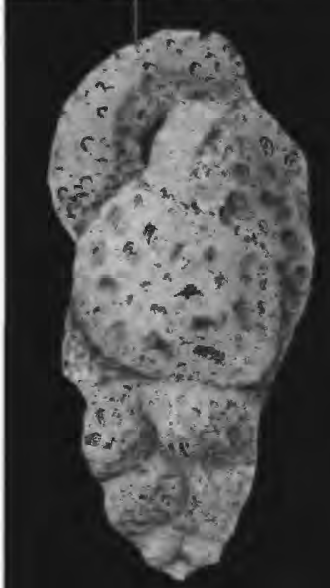

1 a

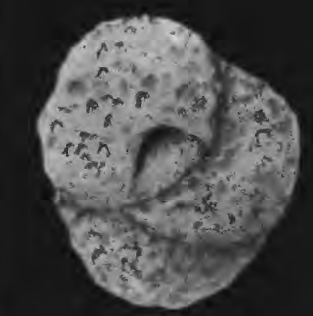

$1 \mathrm{~b}$

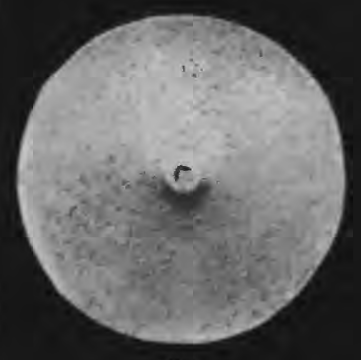

$5 a$

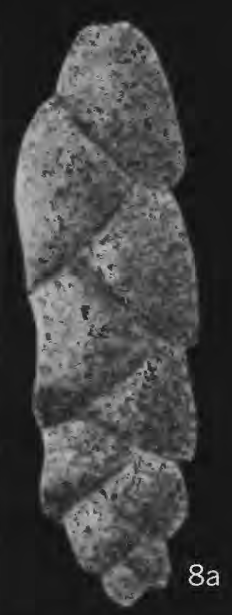

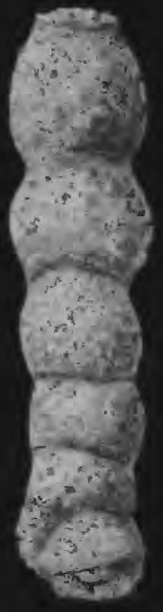

$2 a$

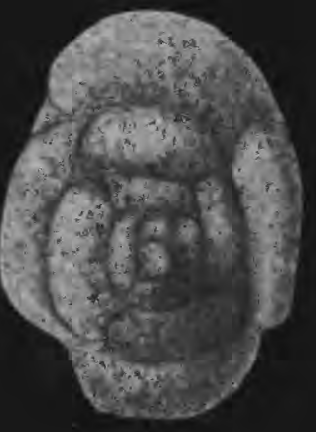

$4 a$

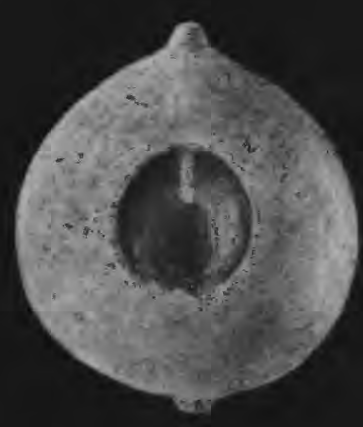

$5 b$

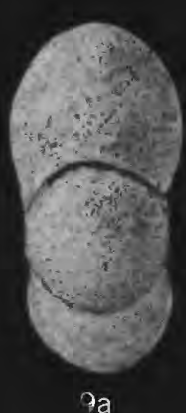

$8 b$
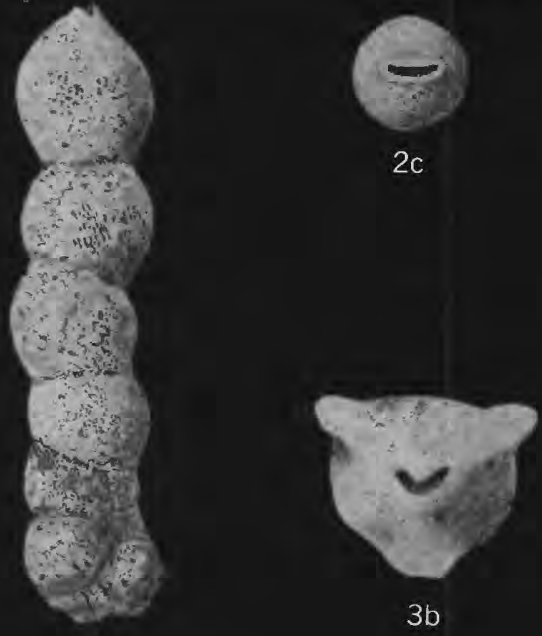

$2 b$

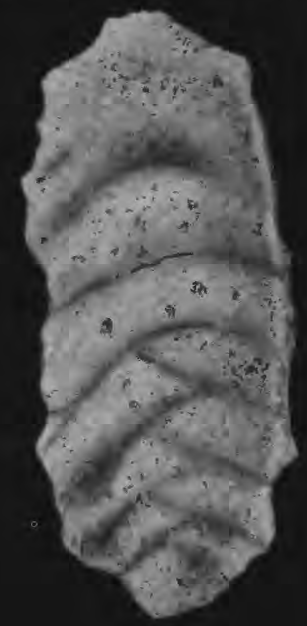

$3 a$

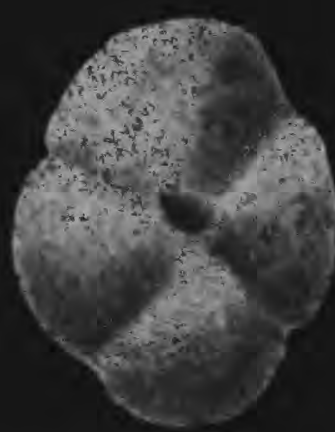

$4 \mathrm{c}$

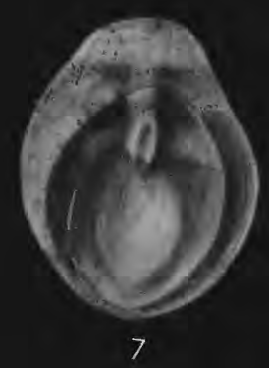

6

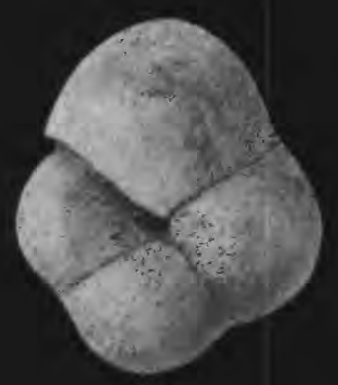

$9 b$

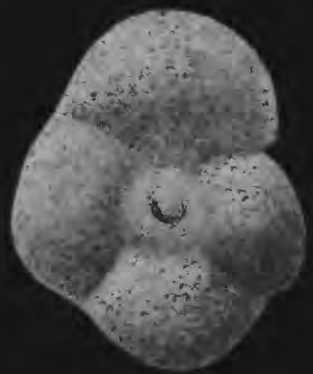

$9 c$

VERNEUILINOIDES, PSEUDOCLAVULINA?, CLAVULINOIDES, TROCHAMMINA OOLINA, FISSURINA, ?LOXOSTOMA, AND "DISCORBIS" 


\section{PLATE 2}

Figure 1. Nuttallinella? disca Mello, n. sp. (p. 91).

Holotype, USNM 642667. Locality 41, sample 10.

$a$, spiral side view; $b$, edge view; $c$, umbilical side view. $\times 300$

2. Pullenia dakotensis Mello, n. sp. (p. 93).

Holotype, USNM 642672. Locality 7, sample 30.

$a$, edge view; $b$, side view. $\times 112$.

3-5. Biglobigerinella biforaminata (Hofker) (p. 95).

$3 a, b$. Side and edge views of specimen with single final chamber and single peripheral aperture, USNM 642677. Locality 27, sample 6 . $\times 148$.

4. Edge view of specimen with single final chamber and paired lateral apertures. USNM 642676. Locality 27 , sample 6 . $\times 148$.

5. Edge view of specimen with paired final chambers each with an umbilically directed aperture. USNM 642675. Locality 3, sample 14 . $\times 148$.

6. Rugoglobigerina cf. R. rugosa (Plummer) (p. 94).

USNM 642674. Locality 41, sample 10. a, edge view; b, spiral side view; c, umbilical side view. $\times 148$.

7, 8. Anomalinoides minuta Mello, n. sp. (p. 96).

7. Paratype, USNM 642681. Locality 41, sample 10. a, umbilical side view; $b$, edge view; c, spiral side view. $\times 220$.

8. Holotype, USNM 642678. Locality 3, sample 18. a, spiral side view; b, edge view; c, umbilical side view. $\times 220$. 


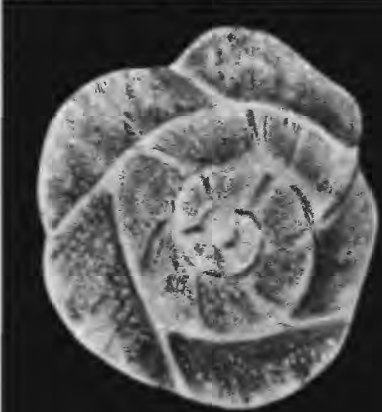

1 a

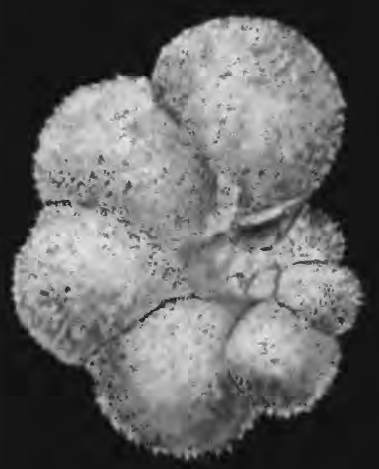

$3 a$

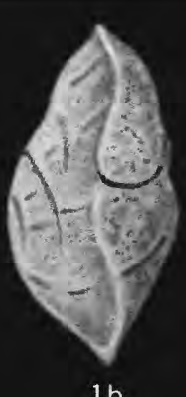

$1 \mathrm{~b}$

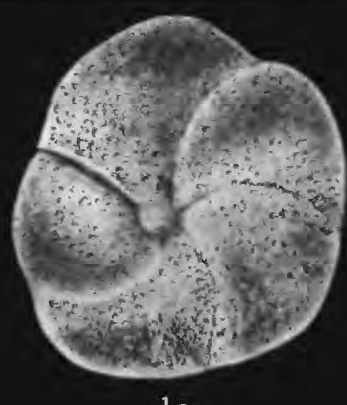

$1 c$

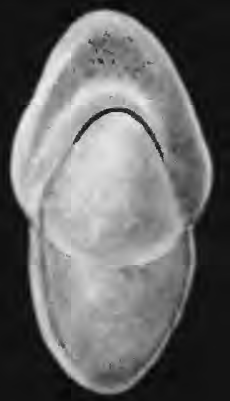

$2 a$
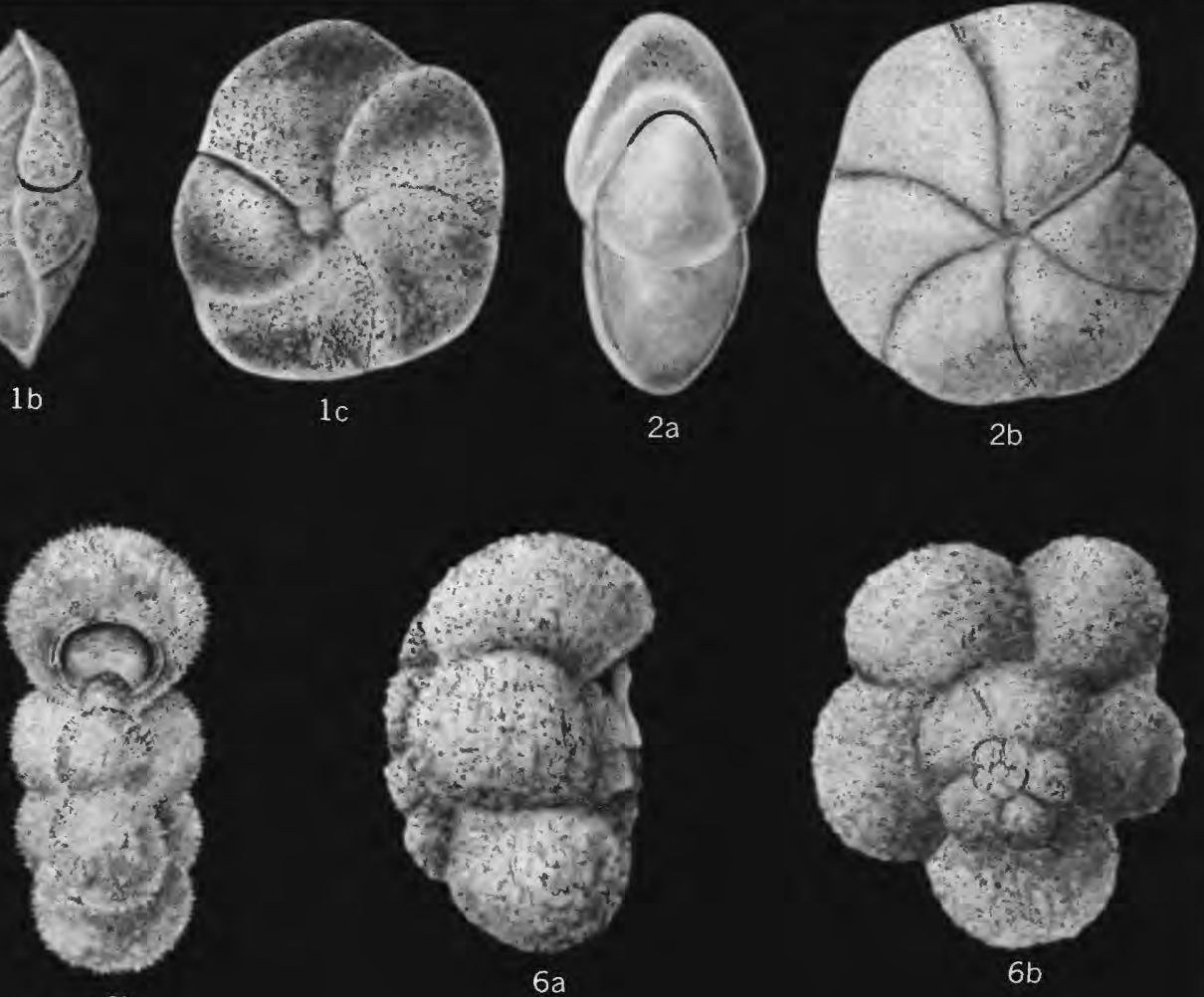

$3 b$
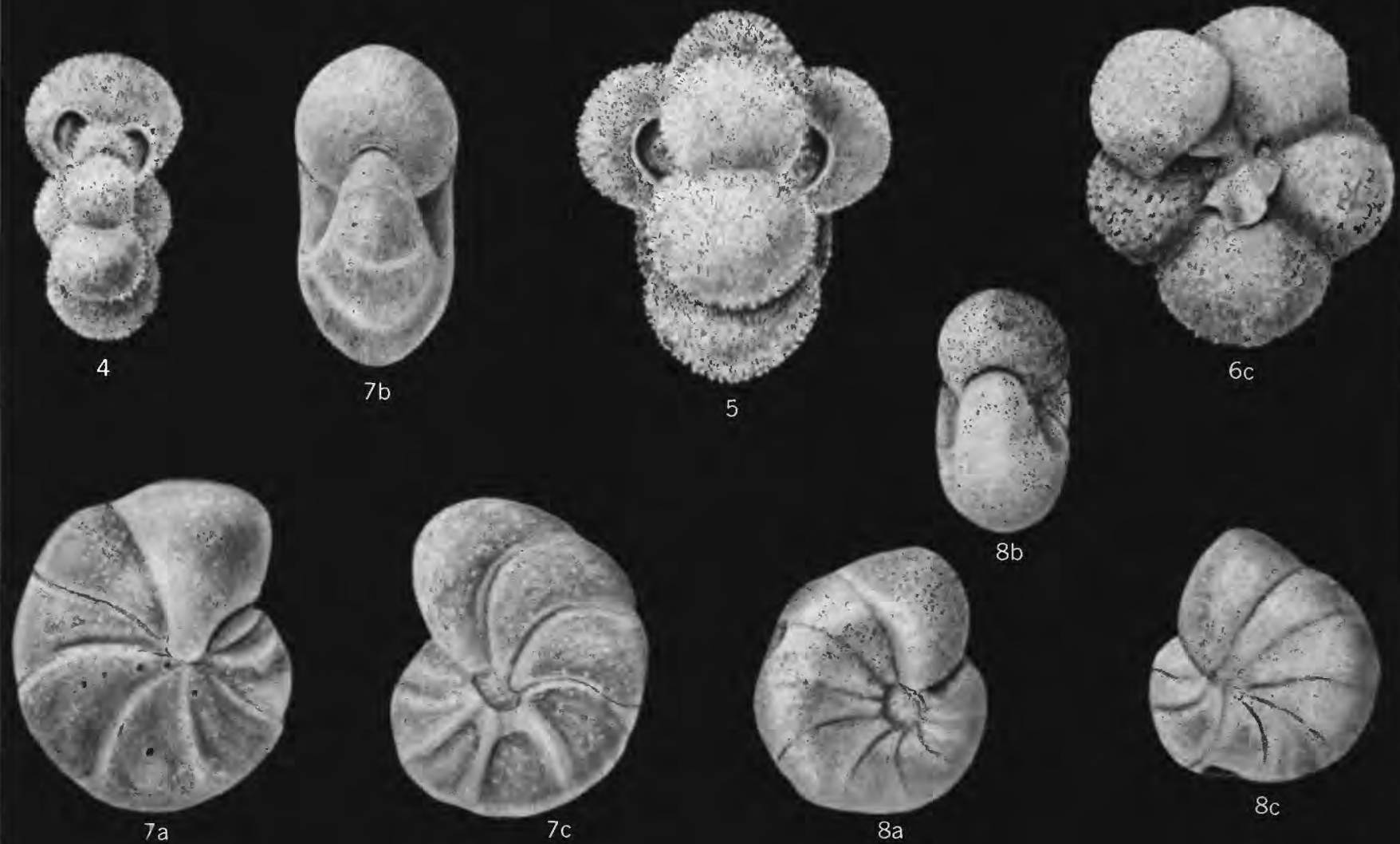

$8 b$

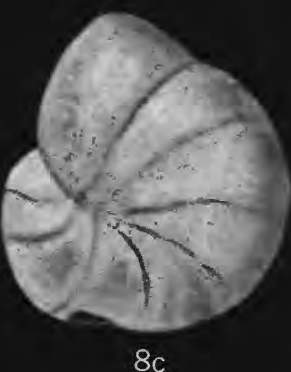

$8 a$

NUTTALLINELLA?, PULLENIA, BIGLOBIGERINELLA, RUGOGLOBIGERINA, AND ANOMALINOIDES 


\section{PLATE 3}

Figure 1. Incertae sedis sp. A (p. 101).

USNM 642690. Locality 7, sample 21. a, apertural view; $b$, basal view; c, edge view. $\times 220$.

2. Anomalinoides minuta Mello? (p. 97).

USNM 642682. Locality 3, sample 18. a, spiral side view; b, edge view; c, umbilical side view. $\times 300$

3. Cibicides mobridgensis Mello, n. sp. (p. 99).

Holotype, USNM 642685. Locality 37, sample 1. a, umbilical side view; b, edge view; c, spiral side view. $\times 220$.

4. Cibicides subcarinatus Cushman and Deaderick (p. 100)

USNM 642689. Locality 7, sample 5. a, umbilical side view; b, edge view; c, spiral side view. $\times 104$. 


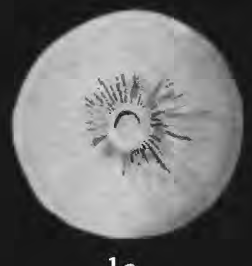

1 a

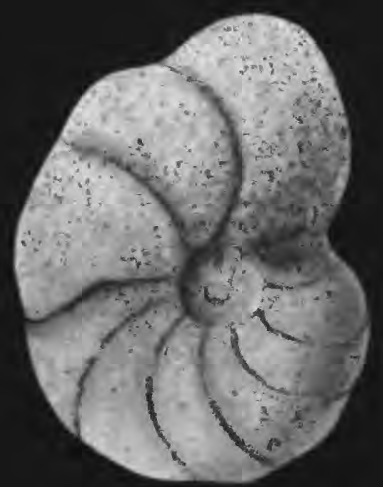

$2 a$
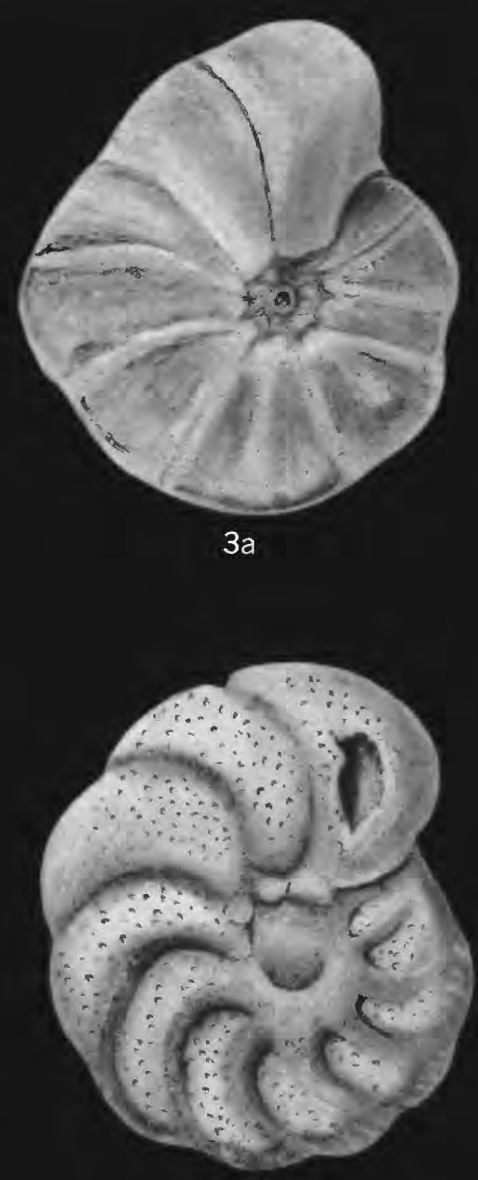

$4 a$

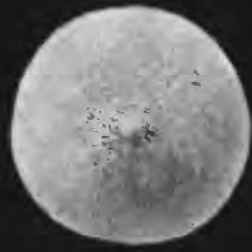

1b

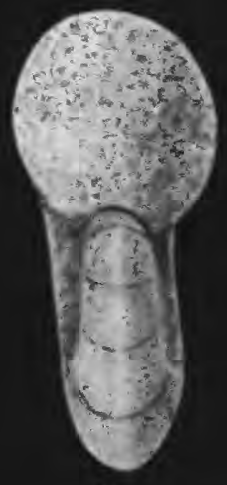

$2 b$

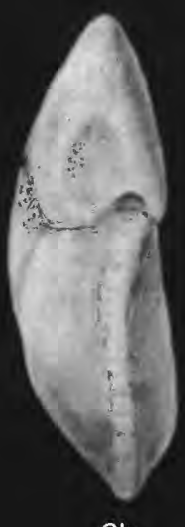

$3 b$

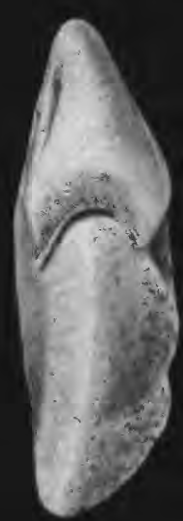

$4 b$
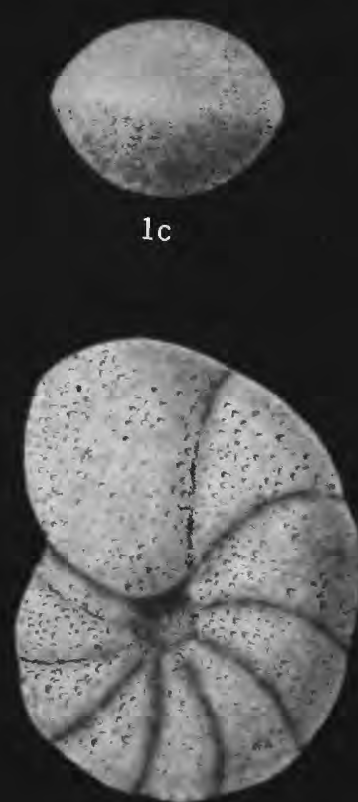

2c
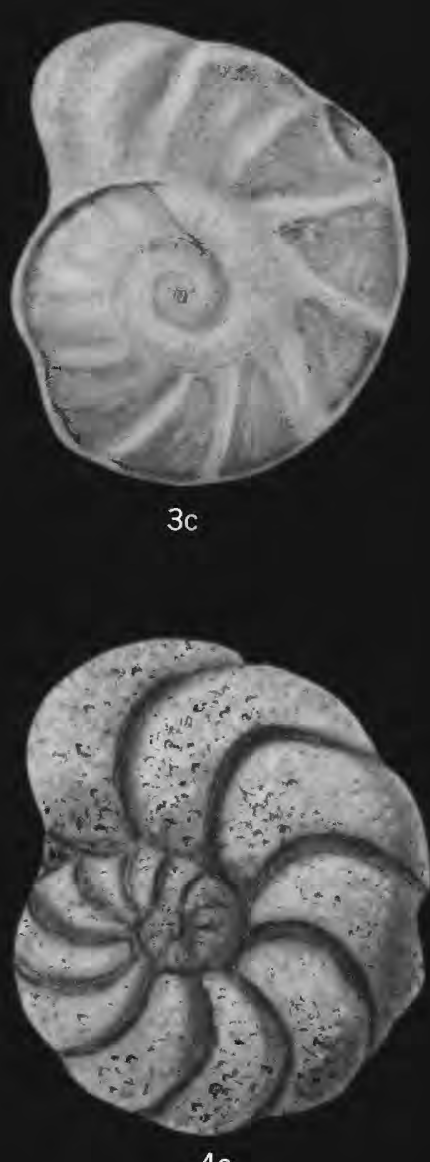

$4 c$ 


\section{PLATE 4}

Figure 1. Bathysiphon brosgei Tappan? (p. 40).

USNM 642565. Locality 3 , sample $1 . \times 80$.

2. Reophax sp. (p. 41).

USNM 642566. Locality 50, sample 3. $\times 75$.

3. Ammodiscus cretaceus (Reuss) (p. 41).

USNM 642567. Locality 3, sample $1 . \times 40$.

4. Glomospira charoides (Jones and Parker) (p. 42).

Distorted specimen, USNM 642568. Locality 3, sample 14. a, oblique view of side and top; $b$, oblique view of base. $\times 150$.

5. Haplophragmoides rota Nauss (p. 42).

USNM 642569. Locality 50, sample 1 . a, edge view; b, side view, $\times 50$.

6. Haplophragmoides bonanzaensis Stelck and Wall (p. 43).

USNM 642570. Locality 53, sample 13 . a, side view; b, edge view. $\times 200$.

7. Spiroplectammina laevis (Roemer) cretosa Cushman (p. 44).

USNM 642571. Locality 3, sample 22. a, edge view; b, side view; c, apertural view. $\times 100$.

8. Spiroplectammina mordenensis Wickenden (p. 45).

USNM 642572. Locality 37, sample 5. a, side view showing exterior; $b$, side view, in glycerin, showing internal arrangement of chambers; c, apertural view; d, edge view. $\times 150$.

9. Gaudryina (Gaudryin) watersi (Cushman) (p. 47).

USNM 642574. Locality 7, sample 30. a, edge view; b, side view; c, apertural view. $\times 75$.

10. Gaudryina boweni Mello, new name (p. 47).

USNM 642576. Locality 41, sample 10. a, edge view; b, side view. $\times 75$.

11. Gaudryina bentonensis (Carman) (p. 48).

(Somewhat compressed specimen), USNM 642577. Locality 1, sample 9. a, edge view, direction of compression perpendicular to plane of this plate; b, side view, direction of compression parallel to plane of this plate. $\times 75$. 

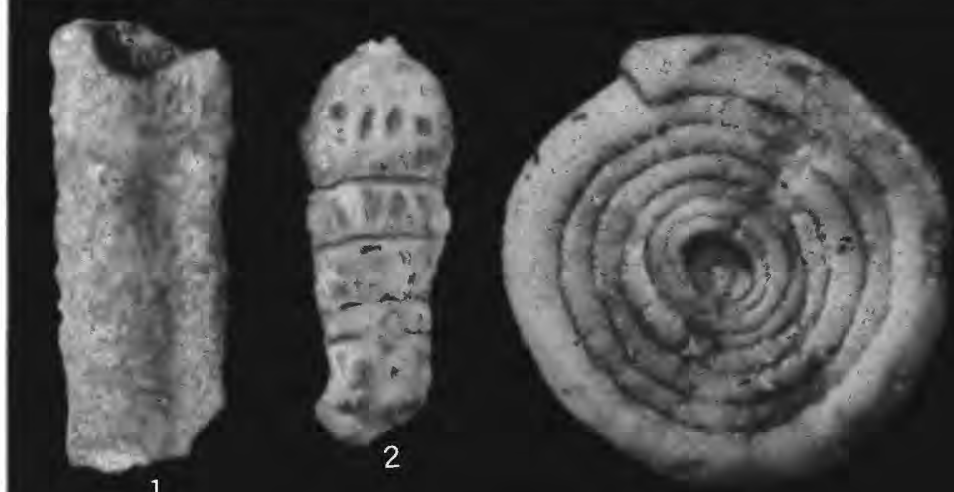

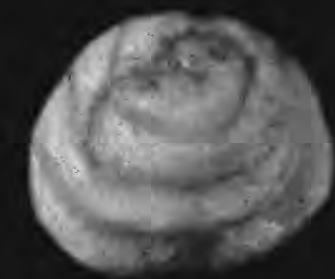

$4 a$

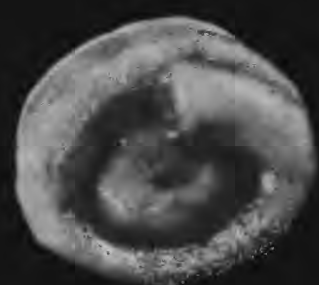

$4 b$

3

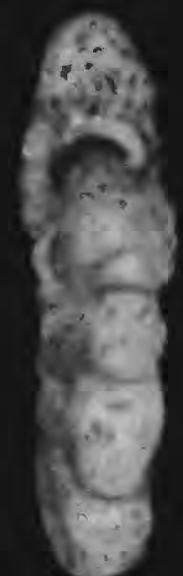

$5 a$

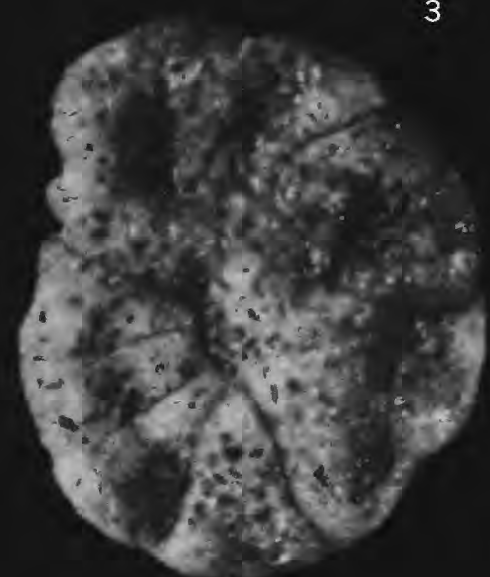

$5 b$

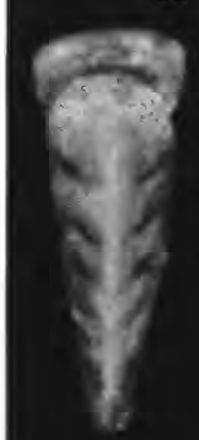

$7 a$

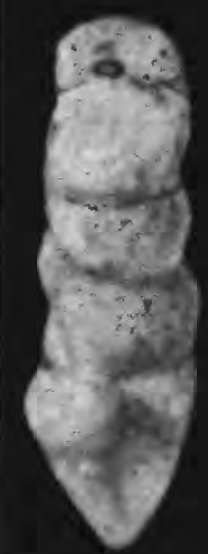

$9 a$

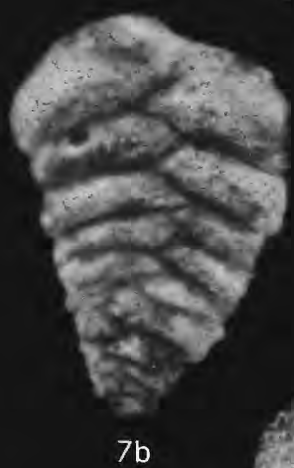

$7 b$

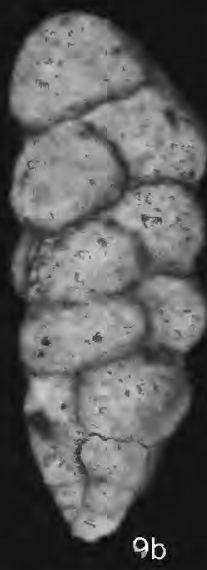

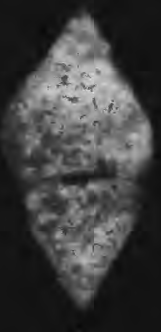

$7 c$

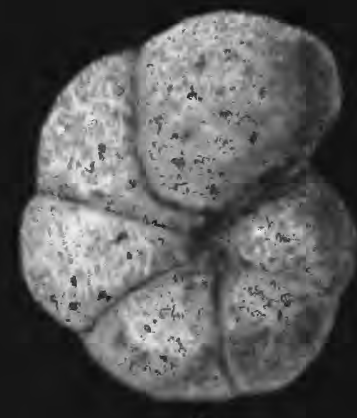

$6 a$

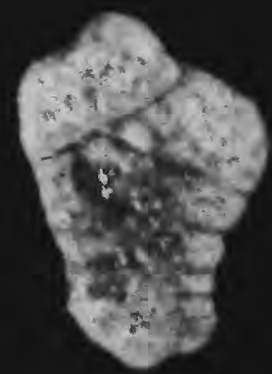

$8 a$

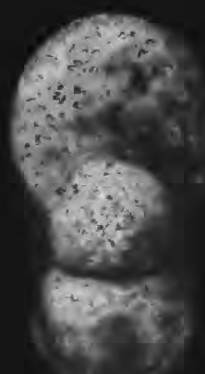

$6 \mathrm{~b}$

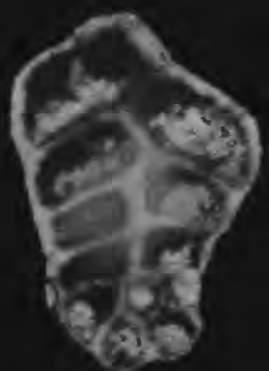

$8 b$

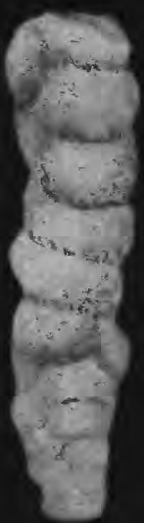

11 a

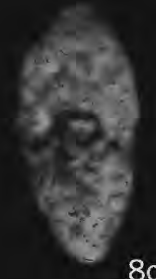

$8 \mathrm{c}$

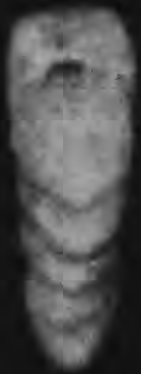

$8 d$

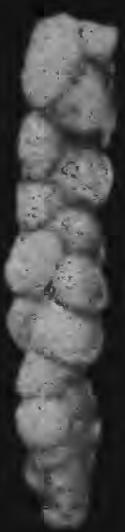

$11 \mathrm{~b}$

BATHYSIPHON, REOPHAX, AMMODISCUS, GLOMOSPIRA, HAPLOPHRAGMOIDES, SPIROPLECTAMMINA, AND GAUDRYINA 


\section{PLATE 5}

Figure 1. Pseudoclavulina? meidamos Mello, n. sp. (p. 49)

Holotype, USNM 642579. Locality 41, sample 1. a, side view; b, apertural view; c, basal view, in glycerin, showing arrangement of early chambers; $d$, side view, in glycerin. $\times 150$.

2. Heterostomella americana Cushman (p. 50).

USNM 642584. Locality 41, sample 5. a, apertural view; b, c, side views. $\times 75$.

3. Silicosigmoilina futabaensis Asano (p. 51).

USNM 642585. Locality 3 , sample 18 . a, edge view; $b$, side view. $\times 75$.

4. Quinqueloculina sp. (p. 51).

USNM 642586. Locality 53, sample 11. a, b, side views; c, apertural view. $\times 200$

5. Trochammina globosa Bolin (p. 52).

USNM 642587. Locality 54, sample 5. a, umbilical side view; b, edge view; c, spiral side view. $\times 150$.

6. Robulus muensteri (Roemer) (p. 53).

USNM 642589. Locality 3 , sample 23 . a, edge view; b, side view. $\times 75$.

7. Robulus taylorensis (Plummer) (p. 54).

USNM 642592. Locality 41, sample 10 . a, edge view; b, side view. $\times 50$.

8, 9. Robulus spissocostatus Cushman (p. 53).

8. Less compressed form with raised and thickened sutures, USNM 642591. Locality 41 , sample 1 . a, side view; b, edge view. $\times 50$.

9. Compressed form with prominent flangelike keel, USNM 642590.

Locality 41, sample 10 . a, side view; $b$, edge view. $\times 50$. 

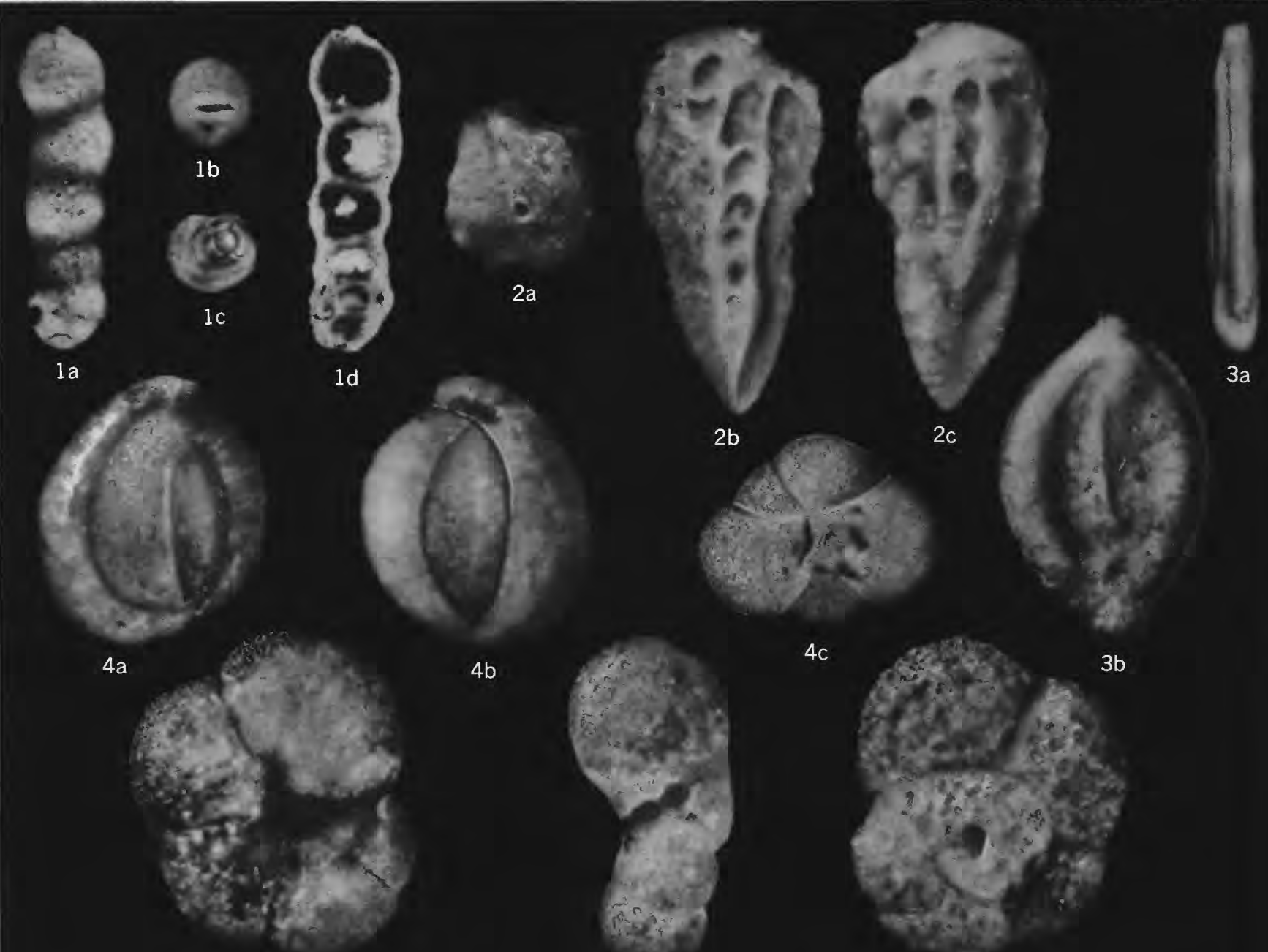

$5 a$

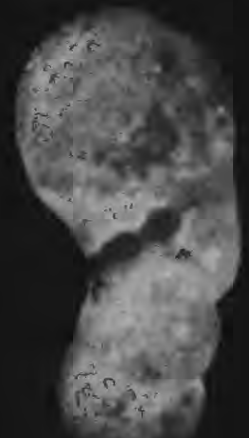

$4 c$

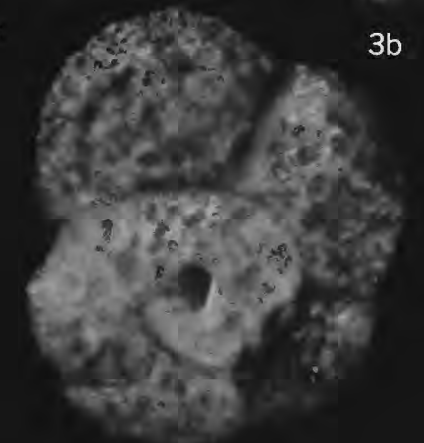

$5 b$

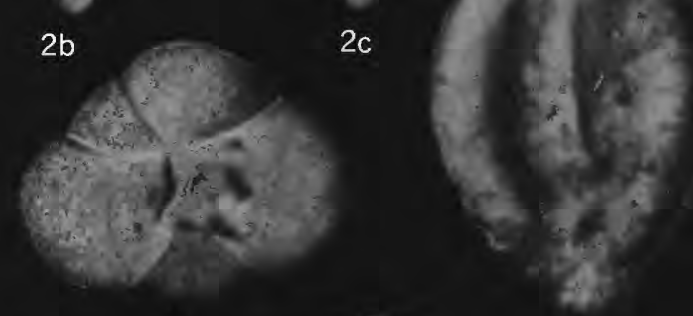

$3 b$

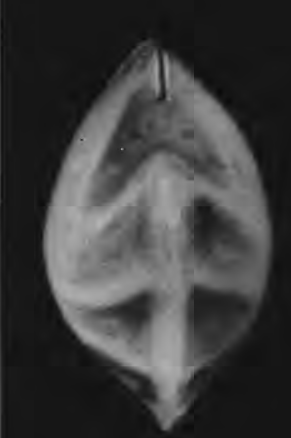

$6 a$

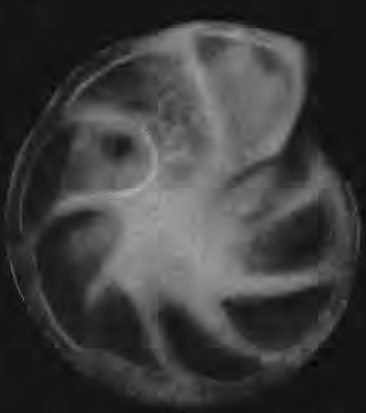

$6 b$

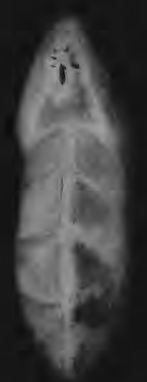

$7 a$

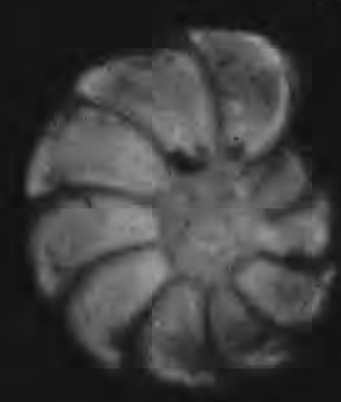

$7 \mathrm{~b}$

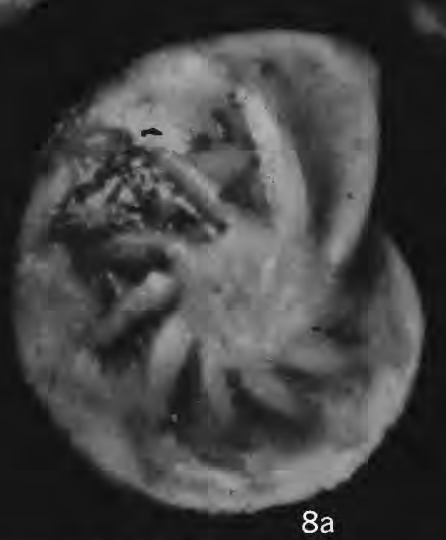

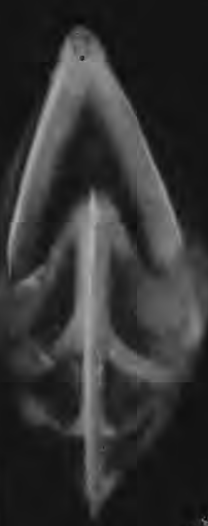

$8 b$

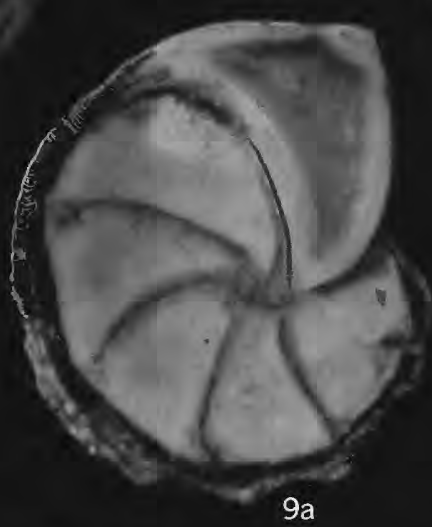

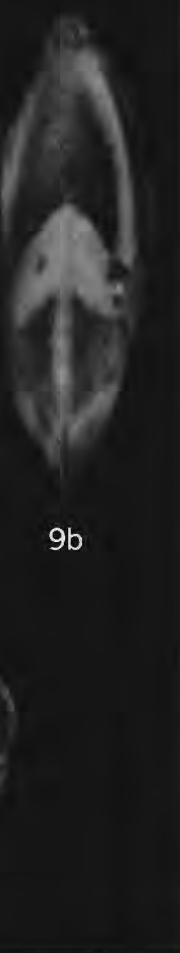

$5 c$

$8 a$ 


\section{PLATE 6}

Figure 1. Marginulina curvatura Cushman (p. 55).

USNM 642593. Locality 7, sample 15. a, side víew; b, front view. $\times 150$.

2. Astacolus cretaceus (Cushman) (p. 56).

USNM 642594. Locality 27, sample 4. a, front view; b, side view; c, front view, in glycerin; d, side view, in glycerin. $\times 100$.

3. Astacolus rectus (d'Orbigny') (p. 56).

USNM 642595. Locality 4, sample 5. a, front view; b, side view. $\times 100$.

4. Astacolus jarvisellus Mello, new name (p. 57).

USNM 642596. Locality 7, sample 7. a, front view; b, side view. $\times 100$.

5. Astacolus narvarroanus (Cushman) (p. 57).

USNM 642597. Locality 7, sample 23. a, front view; b, side view. $\times 100$.

6. Astacolus dissonus Plummer (p. 58).

USNM 642598. Locality 41, sample 10 . Side view. $\times 27$.

7. Dentalina catenula Reuss (p. 58).

USNM 642599. Locality 3, sample 18. Side view. $\times 75$.

8. Dentalina niobrarensis Loetterle (p. 58).

USNM 642600. Locality 41, sample 3. a, side view; b, front view. $\times 100$.

9. Dentalina ef. D. consobrina d'Orbigny (p. 59).

USNM 642601. Locality 41, sample 10. a, side view; b, side/view, in glycerin, unretouched photograph. $\times 50$.

10. Dentalina gracilis d'Orbigny (p. 59).

USNM 642602. Locality 39, sample 1 . a, side view; b, front view. $\times 100$.

11. Dentalina legumen Reuss (p. 60).

USNM 642603. Locality 3, sample 14. Side view. $\times 100$.

12. Dentalina pertinens Cushman (p. 60).

USNM 642604. Locality 41, sample 9. a, side view; b, dorsal (convex side) view. $\times 50$.

13, 14. Dentalina solvata Cushman (p. 60).

13. USNM 642605. Locality 7, sample 1 . Side view. $\times 100$.

14. USNM 642606. Locality 4, sample 5. Side view. $\times 50$.

15. Nodosaria affinis Reuss (p. 61).

USNM 642607. Locality 41, sample 10 . Side view. $\times 50$.

16. Nodosaria proboscidea Reuss (p. 61).

USNM 642608. Locality 41, sample 5. Side view. $\times 50$.

17. Nodosaria of. $N$. aspera Reuss (p. 61).

USNM 642609. Locality 36, sample 2 . Side view. $\times 50$.

18. Nodosaria fusula Reuss (p. 62).

USNM 642610. Locality 37 , sample 6 . Side view. $\times 100$.

19. Nodosaria gracilitatis Cushman (p. 62).

USNM 642611. Locality 41, sample 1. Side view of partial specimen. $\times 50$. 


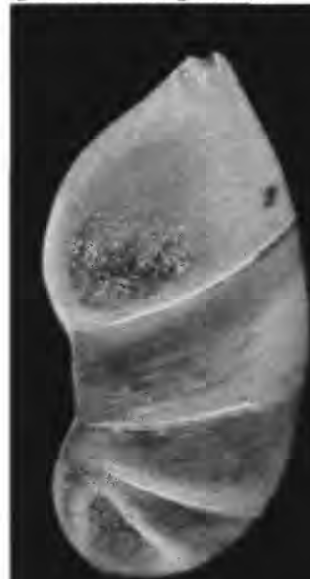

$1 \mathrm{a}$

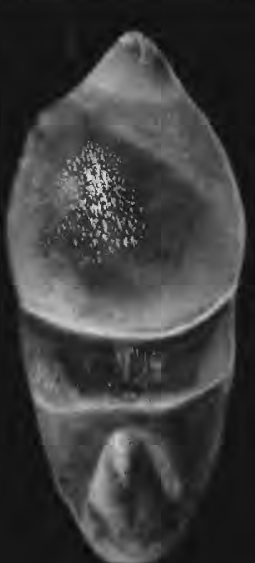

$1 \mathrm{~b}$

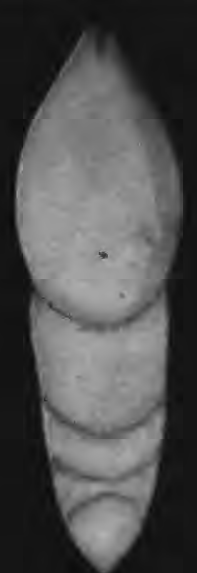

$2 a$

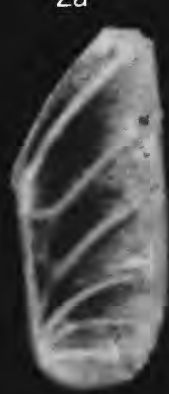

$4 b$

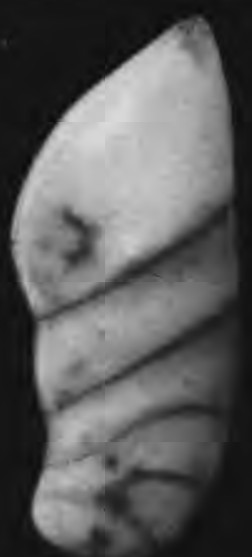

$2 \mathrm{~b}$

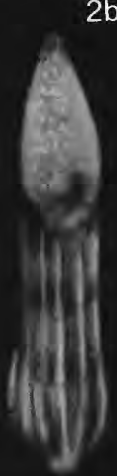

$5 a$

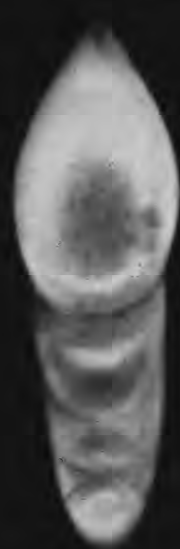

$2 c$

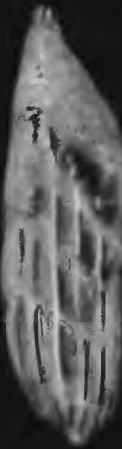

$5 b$
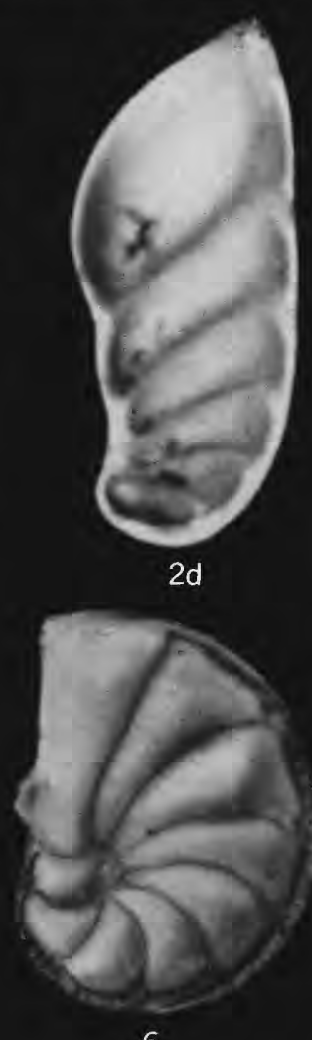

6
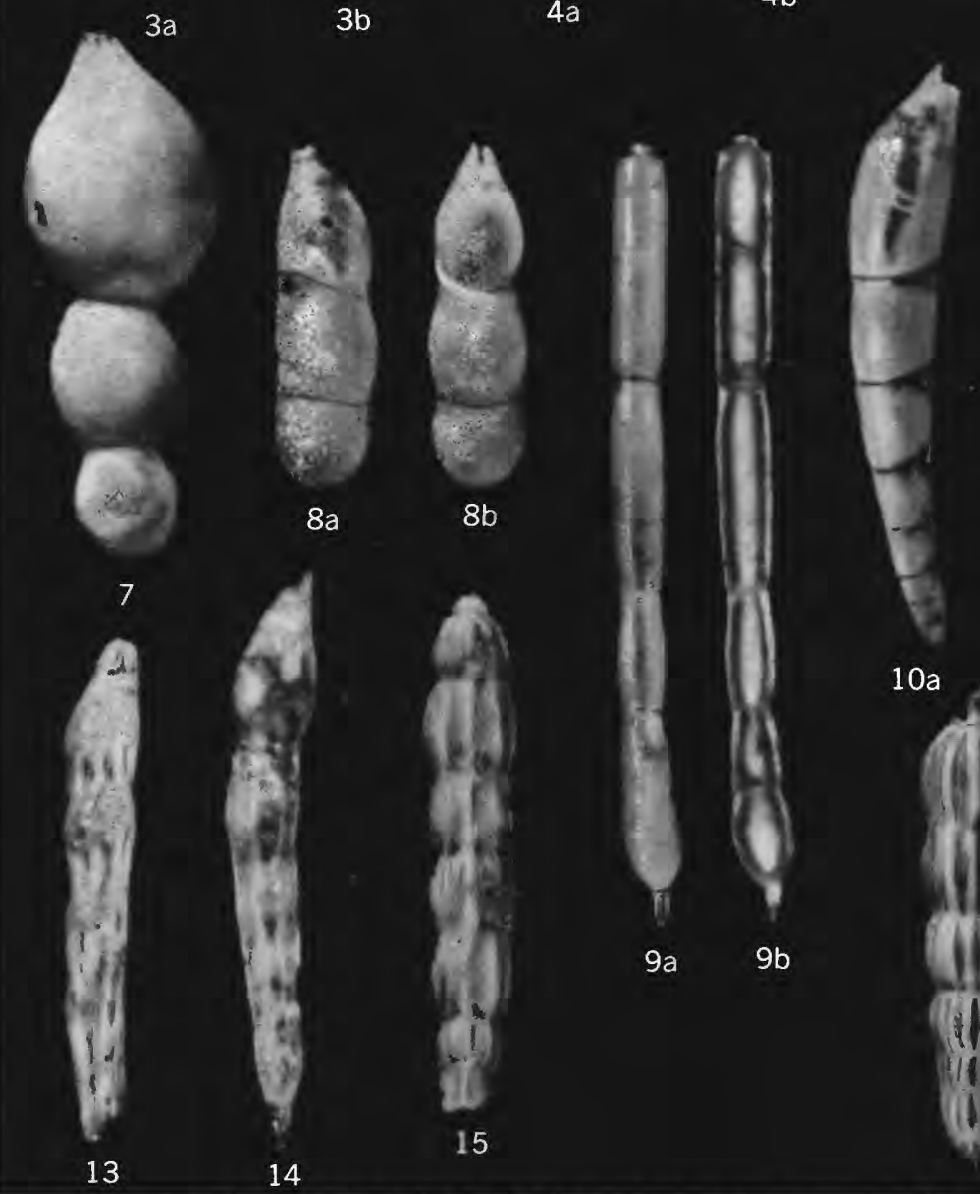

$10 a$
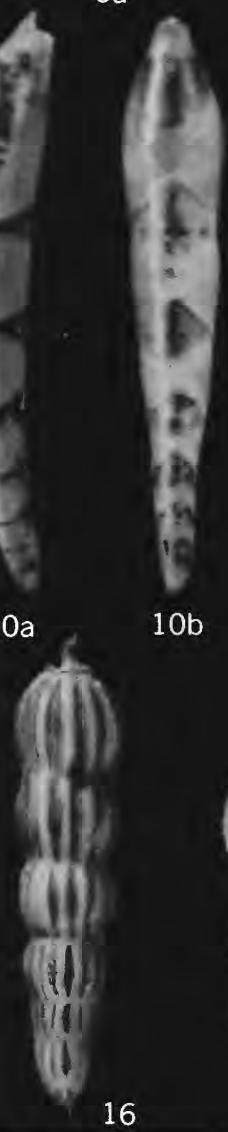

$10 \mathrm{~b}$
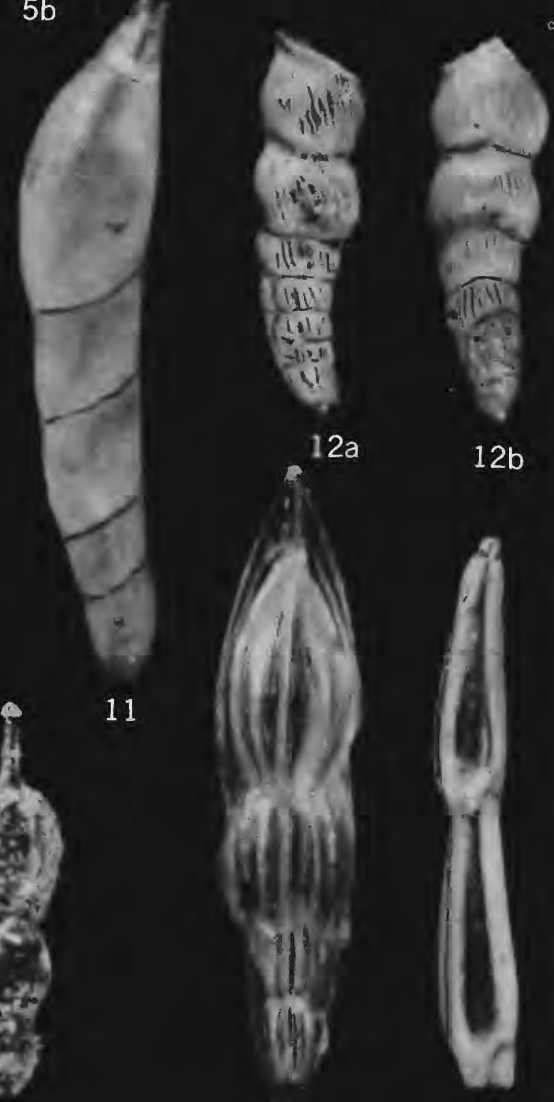

18 


\section{PLATE 7}

Figures 1, 2. Rectoglandulina appressa Loeblich and Tappan (p. 62).

1. USNM 642612. Locality 39, sample 1. a, side view, showing pattern of two lateral and two central vertical lines of less transparent shell on the final chamber; $b$, side view, in glycerin, showing chamber arrangement and smooth walls. $\times 150$.

2. USNM 642613. Locality 3, sample 22. a, side view; b, side view, in glycerin (unretouched photo.). $\times 200$.

3. Citharina sp. A (p. 63).

USNM 642614. Locality 41 , sample 10 . Side view. $\times 75$.

4. Citharina sp. B (p. 63).

USNM 642615. Locality 7, sample 1. a, side view; b, edge view of straight margin. $\times 50$.

5. Palmula primitiva Cushman (p. 64).

USNM 642616. Locality 3, sample 16 . Side view, in glycerin. $\times 100$.

6. Palmula reticulata (Reuss) (p. 64).

USNM 642617. Locality 36, sample 3. a, side view; b, edge view; c, side view, in glycerin. $\times 50$.

7. Palmula cf. P. rugosa (d'Orbigny) (p. 64).

USNM 642618. Locality 36 , sample 3 . Side view. $\times 75$.

8. Frondicularia archiaciana d'Orbigny (p. 65).

USNM 642619. Locality 3, sample 14. a, side view (unretouched photo); b, edge view. $\times 30$.

9. Lagena sp. aff. L. quadralata Brady (p. 65).

USNM 642620 . Locality 41 , sample 1 . Side view. $\times 150$.

10. Lagena sulcata (Walker and Jacob) semiinterrupta W. Berry (p. 65).

USN M 642621. Locality 3, sample 22. a, basal view; b, side view. $\times 200$.

11. Lagena apiculata Reuss (p. 66).

USNM 642622. Locality 3, sample 18 . Side view. $\times 75$.

12, 13. Oolina obeliscata Mello, n. sp. (p. 66).

12. Paratype, USNM 642623. Locality 27, sample 6. Side view of whole specimen. $\times 200$.

13. Paratype, USNM 642624. Locality 27, sample 6. Oblique view toward the apertural end of an etched specimen showing the internal tube. $\times 200$.

14. Fissurina sp. A (p. 67).

USNM 642627. Locality 41, sample 9. a, side view; b, apertural view. $\times 200$.

15, 16. Guttulina trigonula (Reuss) (p. 68)

15. USNM 642628. Locality 4, sample 5. a, side view; b, same side view, in glycerin; c, opposite side view; $d$, opposite side view, in glycerin. $\times 100$.

16. USNM 642629. Locality 3 , sample 18. Basal view of dissected specimen. $\times 150$.

17, 18. Globulina lacrima Reuss (p. 68).

17. USNM 642630 . Locality 3 , sample 22 . a, side view; b, opposite side view. $\times 150$.

18. USNM 642631. Locality 4, sample 4. Basal view of dissected specimen. $\times 150$. 


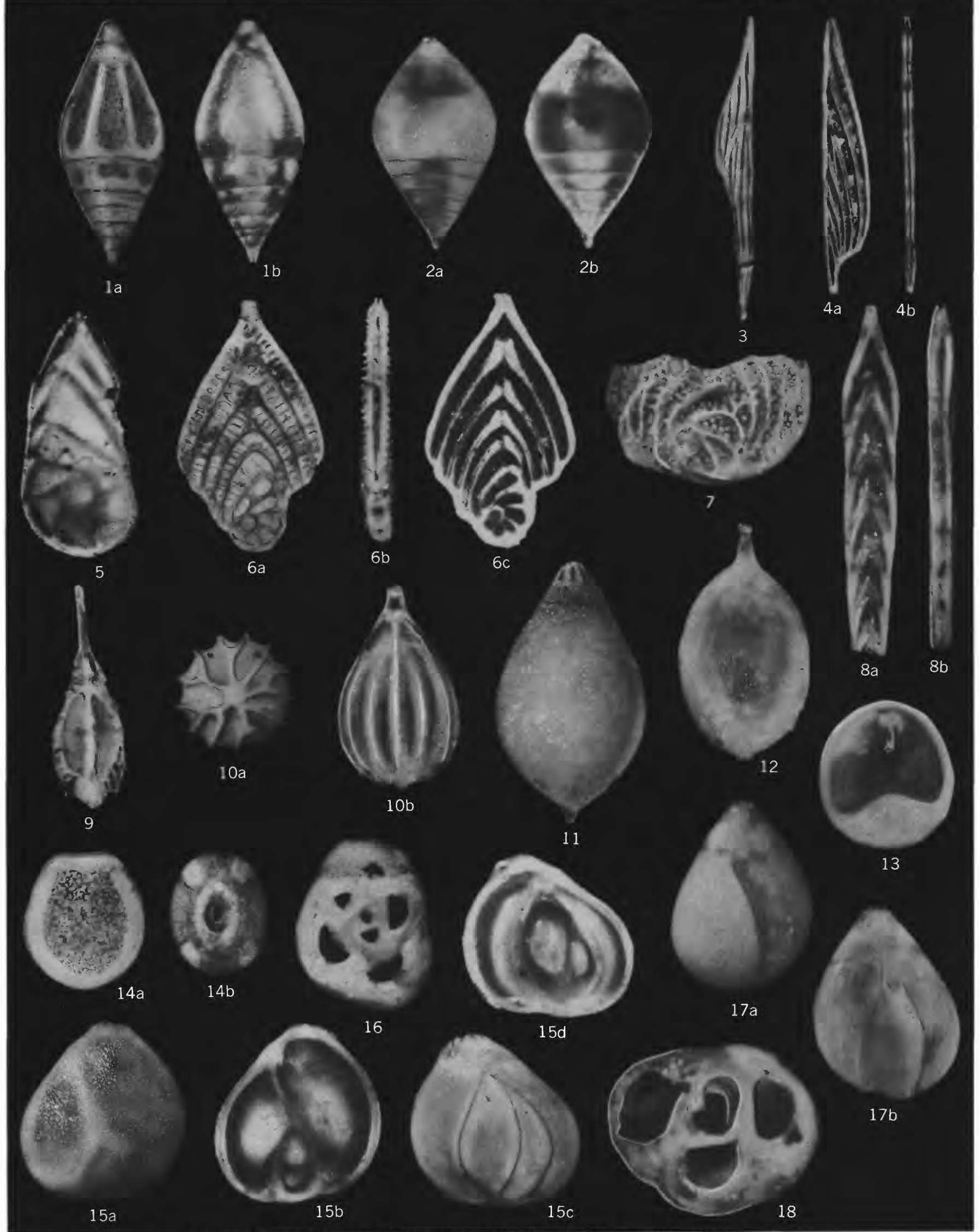

RECTOGLANDULINA, CITHARINA, PALMULA, FRONDICULARIA,

LAGENA, OOLINA, FISSURINA, GUTTULINA, AND GLOBULINA 


\section{PLATE 8}

Figure 1. Pyrulina cylindroides (Roemer) (p. 69).

USNM 642632. Locality 3, sample 14. a, b, views of opposite sides of the test; $c$, apertural view. $\times 75$.

2. Ramulina sp. A (p. 70).

USNM 642634. Locality 7, sample 15. a, side view; b, apertural view. $\times 100$.

3. Ramulina cf. R. muricatina Loeblich and Tappan (p. 69).

USNM 642633. Locality 41, sample 10. Side view. $\times 100$.

4. Heterohelix pulchra (Brotzen) (p. 71).

USNM 642636. Locality 7, sample 13. a, side view; b, edge view. $\times 200$.

5. Heterohelix globulosa (Ehrenberg) (p. 70).

USNM 642635. Locality 7, sample 13. a, side view; b, edge view. $\times 75$.

6. Bolivinopsis rosula (Ehrenberg) (p. 72).

USNM 642637. Locality 41 , sample 9. Side view. $\times 100$.

7. Rectoguembelina minuta Cushman (p. 73).

USNM 642638. Locality 3 , sample 18. Side view. $\times 200$.

8. Bolivinoides decoratus (Jones) australis Edgell (p. 73).

USNM 642639. Locality 41, sample 10. a, apertural view; b, side view. $\times 70$.

9. Tappanina costifera (Cushman) (p. 74).

USNM 642640. Locality 13 , sample 3 . a, side view; b, edge view. $\times 200$.

10. Eouvigerina hispida Cushman (p. 74).

USNM 642642. Locality 36, sample 4. a, side view; b, edge view. $\times 150$.

11. Eouvigerina aspera (Marsson) inflata Marie? (p. 74).

USNM 642641. Locality 36, sample 3. a, edge view, b, side view; c, side view, in glycerin; $d$, apertural view. $\times 200$.

12, 13. Bu'imina arkade'phiana Cushman and Parker (p. 77).

12. USNM 642647. Locality 7 , sample 15 . Oblique view showing apertural toothplate. $\times 150$.

13. USNM 642646. Locality 7, sample 15 . a, side view; b, apertural view. $\times 150$.

14, 15. Bulimina kickapooensis Cole (p. 75).

14. USNM 642645. Locality 27 , sample 6. Unusual specimen with an aperture in each of two final chambers. a, apertural view; $b$, side view. $\times 50$.

15. USNM 642644. Locality 27 , sample 6 . a, apertural view; b, side view. $\times 100$. 


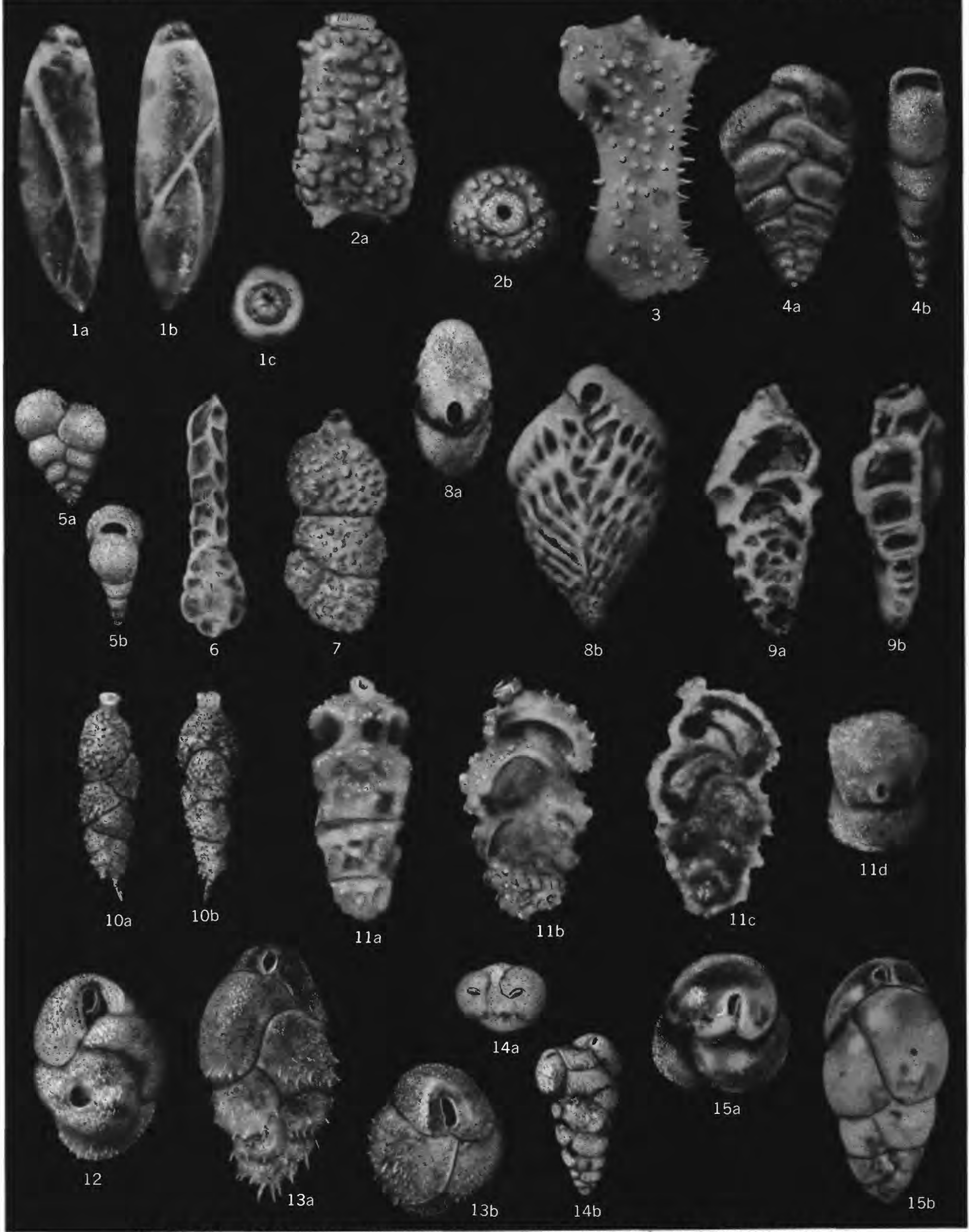

PYRULINA, RAMULINA, HETEROHELIX, BOLIVINOPSIS, RECTOGUEMBELINA,

BOLIVINOIDES, TAPPANINA, EOUVIGERINA, AND BULIMINA 


\section{PLATE 9}

Figure 1. Bulimina reussi Morrow navarroensis Cushman and Parker (p. 75).

USNM 642643. Locality 41, sample 9. a, side view; b, side view, in glycerin; c, apertural view. $\times 200$.

2. Bulimina prolixa Cushman and Parker (p. 77).

USNM 642648. Locality 20, sample 17. a, b, side views; c, apertural view. $\times 200$.

3. Neobulimina navarroana (Cushman) (p. 80).

USNM 642651. Locality 7, sample 30. a, b, side views; c, apertural view. $\times 150$.

4. Neobulimina canadensis Cushman and Wickenden var. beta, n. var. (p. 79).

USNM 642650. Locality 7, sample 30. a, apertural view; b, c, side views. $\times 200$

5. Neobulimina canadensis Cushman and Wickenden var. alpha, n. var. (p. 78).

USNM 642649. Locality 37, sample 1. a, apertural view; b, c, side views. $\times 200$.

6. Bolivina decurrens (Ehrenberg) (p. 81).

USNM 642652. Locality 7, sample 21 . a, edge view; b, side view. $\times 150$.

7. Loxostoma gemma (Cushman) (p. 81).

USNM 642653. Locality 3, sample 14. a, side view; b, edge view. $\times 75$.

8. Pleurostomella nitida Morrow (p. 84).

USNM 642658. Locality 39, sample 1. a, front view; b, side view. $\times 150$.

9, 10. Loxostoma plaita (Carsey) (p. 82).

9. USNM 642654. Locality 27 , sample 1 . a, edge view; b, side view. $\times 75$.

10. USNM 642655 . Locality 27 , sample 1 . a, side view, $\times 75 ; \mathrm{b}$, edge view, $\times 75$; c, side view, in glycerin, $\times 75$ (unretouched photo.); d, partial edge view, showing apertural toothplate, $\times 150$.

11. Stilostomella pseudoscripta (Cushman) (p. 83).

USNM 642657. Locality 41, sample 10. a, apertural view; b, side view. $\times 75$. 

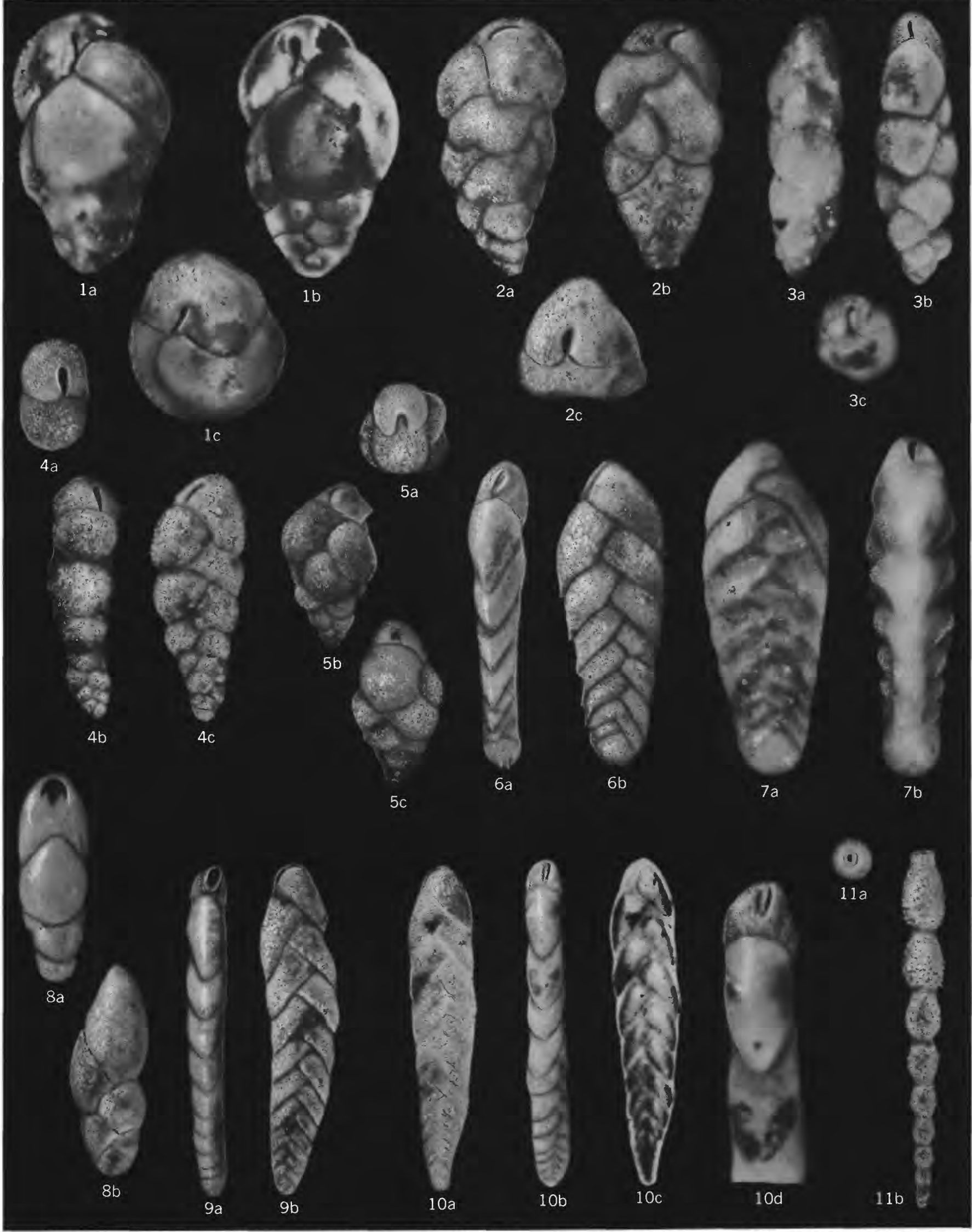

BULIMINA, NEOBULIMINA, BOLIVINA, LOXOSTOMA, PLEUROSTOMELLA, AND STILOSTOMELLA 


\section{PLATE 10}

Figure 1. "Gyroidina globosa (Hagenow)" (p. 87).

USNM 642660. Locality 3, sample 27. a, umbilical side view; b, spiral side view; c, edge view showing large semitransparent, sparsely perforate apertural face. $\times 150$.

2. Gyroidina depressa (Alth) (p. 85).

USNM 642659. Locality 27, sample 6. a, edge view; b, spiral side view; c, umbilical side view. $\times 200$.

3. Gyroidina girardana (Reuss) (p. 88).

USNM 642661. Locality 4, sample 4. a, spiral side view; b, umbilical side view; c, edge view. $\times 100$.

4. Osangularia navarroana (Cushman) (p. 90).

USNM 642662. Locality 45, sample 1. a, umbilical side view; b, spiral side view; c, edge view. $\times 150$.

5. Quadrimorphina allomorphinoides (Reuss) (p. 90).

USNM 642663. Locality 39, sample 1. a, umbilical side view; b, edge view; c, spiral side view. $\times 200$.

6. "Discorbis" quadrilobus Mello, n. sp. (p. 91).

Holotype, USNM 642665. Locality 7, sample 5. a, spiral side view; b, edge view; c, umbilical side view. $\times 200$.

7. Nuttallinella? disca Mello, n. sp. (p. 91).

Holotype, USNM 642667. Locality 41, sample 10. a, spiral side view; b, spiral side view, in glycerin; c, umbilical side view, in glycerin (unretouched photo.). $\times 200$. 


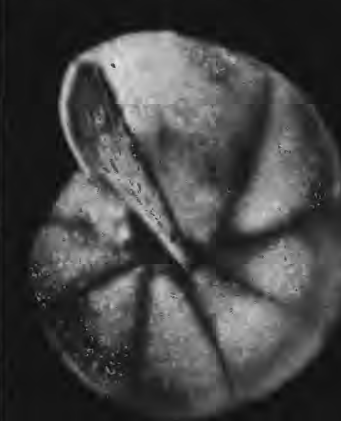

1 a

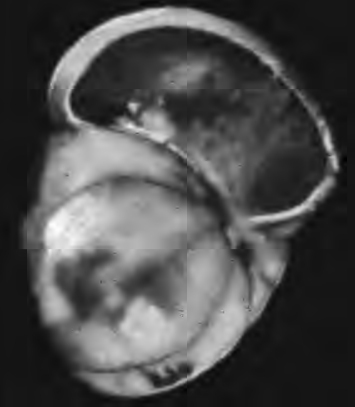

$1 c$

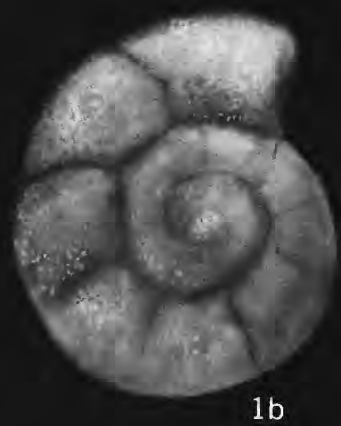

$1 b$

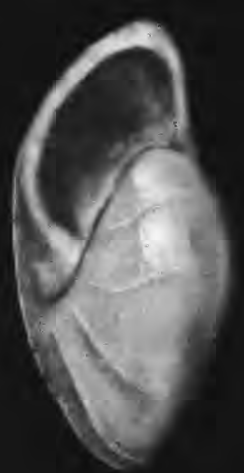

$2 a$

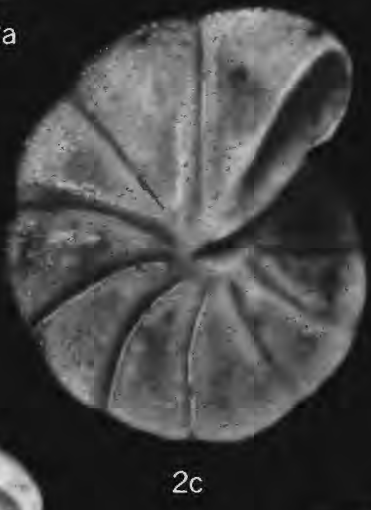

$2 c$

$3 a$
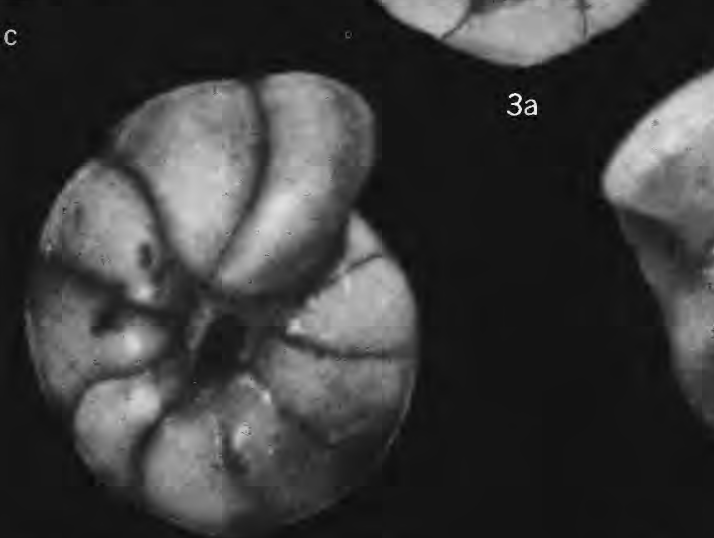

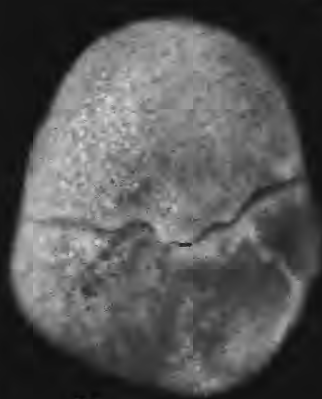

$3 b$

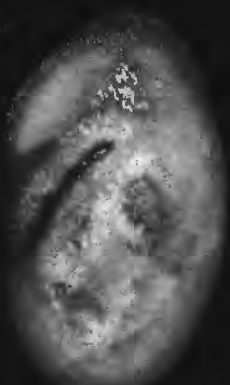

$5 a$

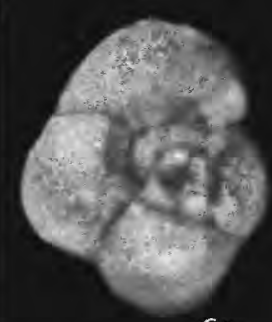

$6 a$

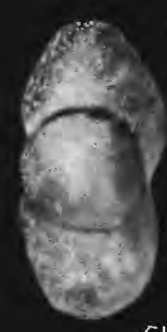

$6 b$
$5 b$

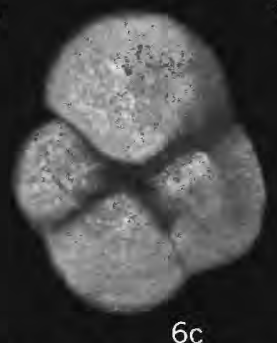

$5 c$
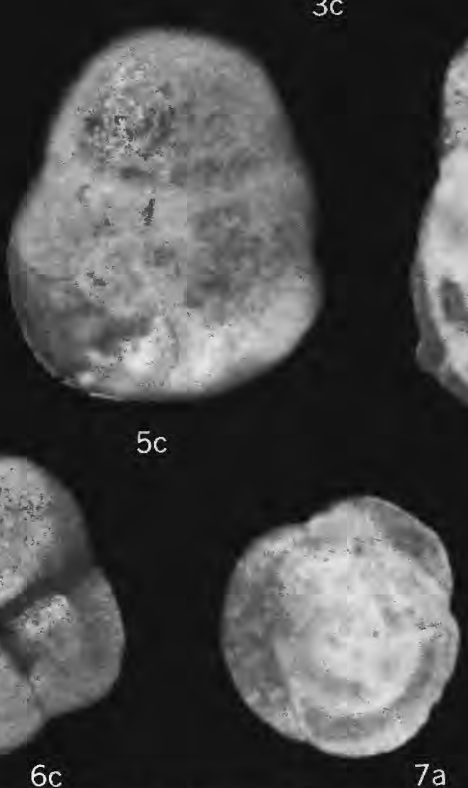

$4 b$

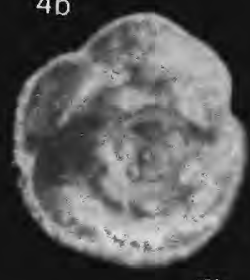

$7 \mathrm{~b}$
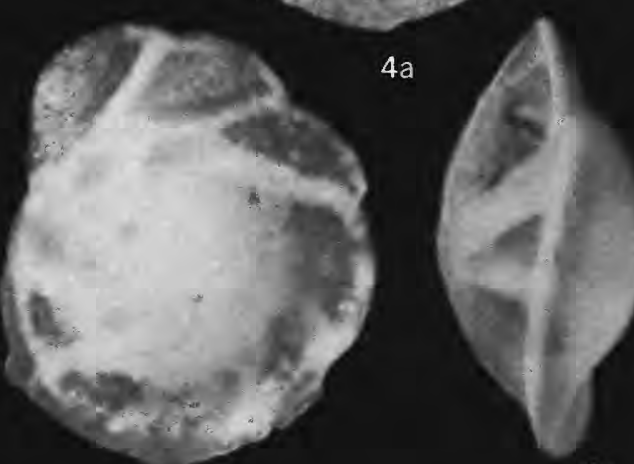

$4 c$

“GYROIDINA," GYROIDINA, OSANGULARIA, QUADRIMORPHINA, “DISCORBIS," AND NUTTALLINELLA? 


\section{PLATE 11}

Figure 1. Hoeglundina supracretacea (ten Dam) (p. 92).

USNM 642671. Locality 27, sample 6. a, spiral side view; b, edge view; c, umbilical side view. $\times 150$.

2. Pullenia dakotensis Mello, n. sp. (p. 93).

Holotype, USNM 642672. Locality 7, sample 30. a, side view; b, edge view. $\times 150$.

3. Planulina sp. (p. 97).

USNM 642683. Locality 20, sample 5. a, umbilical side view; b, edge view; c, ispiral side view; d, spiral side view, in glycerin. $\times 100$.

4. Planulina kansasensis Morrow (p. 98).

USNM 642684. Locality 20 , sample 17 . a, spiral side view; b, edge view; c, umbilical side view. $\times 200$.

5. Cibicides mobridgensis Mello, n. sp. (p. 99).

Paratype, USNM 642687. Locality 41, sample 1. a, edge view; b, umbilical side view; c, umbilical side view, in glycerin (unretouched photo.); $d$, spiral side view. $\times 200$.

6. Cibicides harperi (Sandidge) (p. 100).

USNM 642688. Locality 7 , sample 5 . a, spiral side view; b, edge view; c, umbilical side view. $\times 100$. 

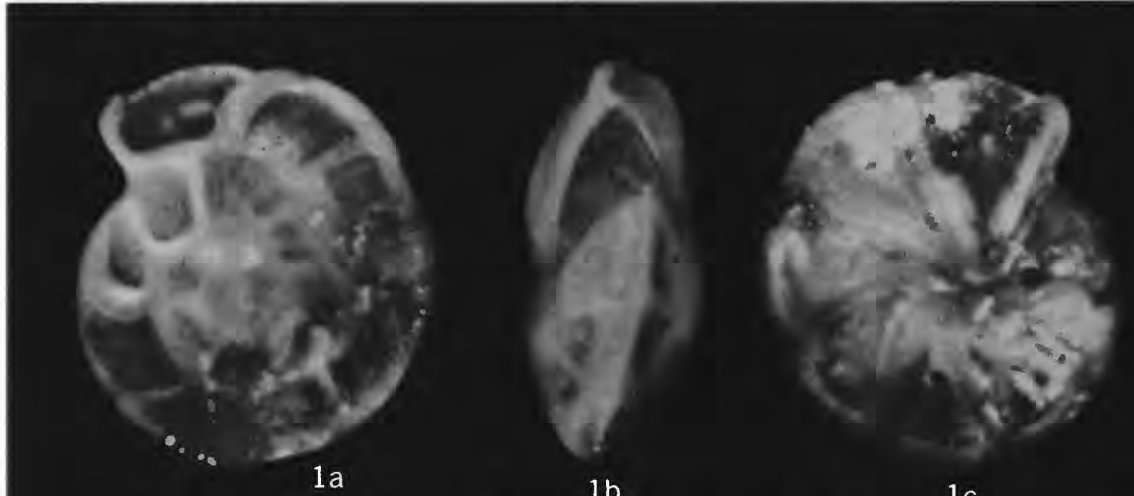

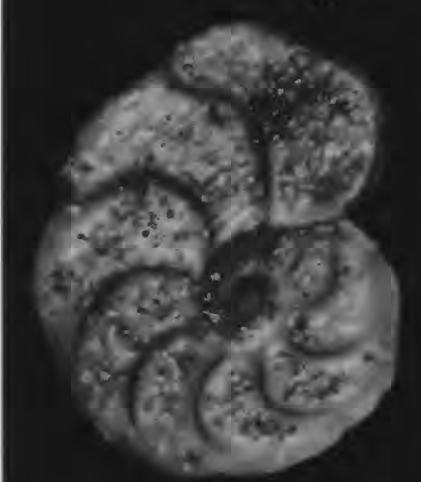

$3 a$

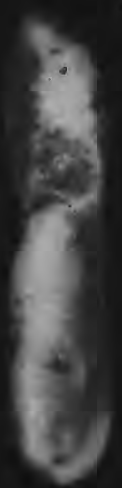

$3 \mathrm{~b}$
$1 \mathrm{~b}$

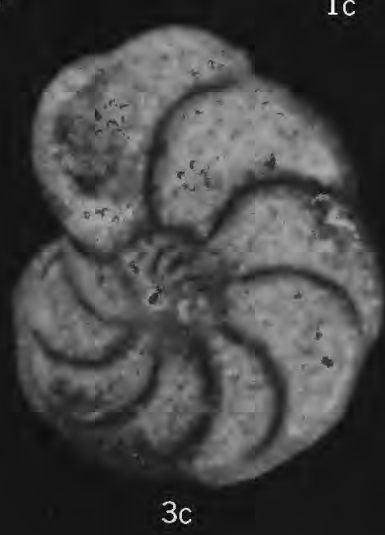

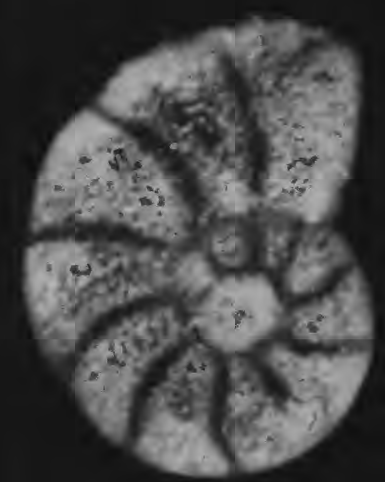

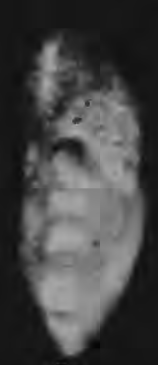

$5 a$

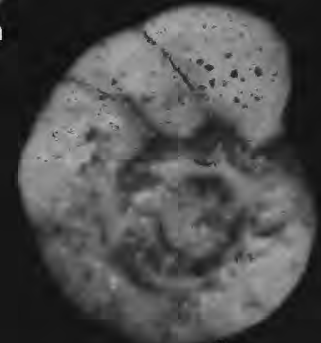

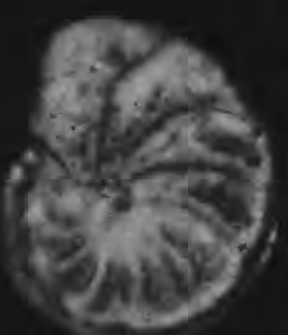

$5 b$

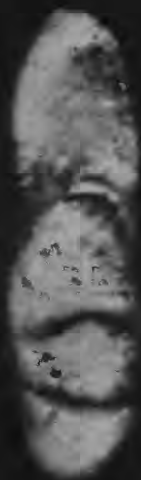

$4 b$
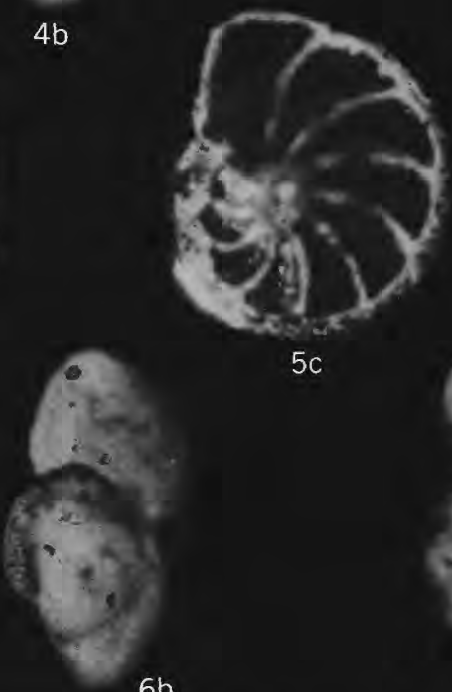

$6 \mathrm{~b}$
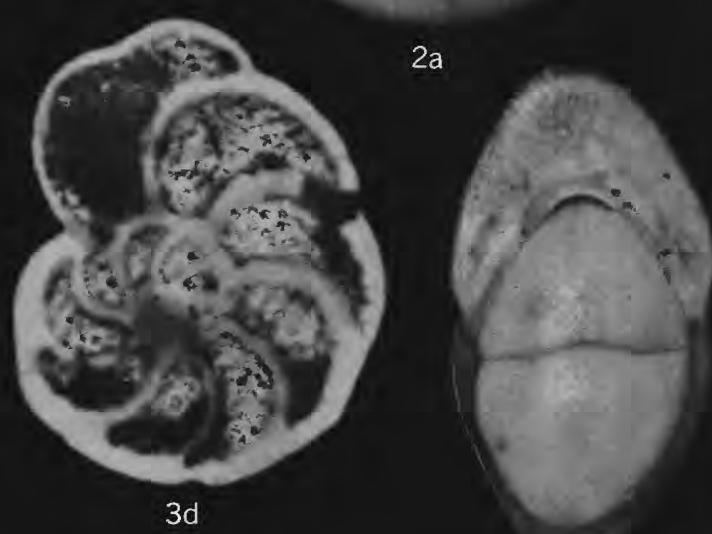

$2 \mathrm{~b}$

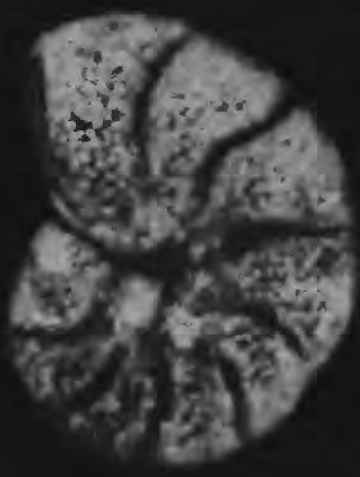

$4 c$

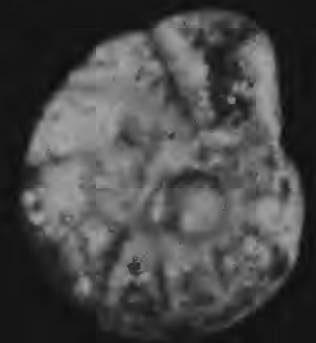

$5 d$

HOEGLUNDINA, PULLENIA, PLANULINA, AND CIBICIDES

U. S. GOVERNMENT PRINTING OFFICE : 1969 O $-323-073$ 